\title{
Appalachian Alter-Natives: The Back-to-the-Land Migration and Community Change in Appalachia, 1970--2000
}

Jinny A. Turman

West Virginia University

Follow this and additional works at: https://researchrepository.wvu.edu/etd

\section{Recommended Citation}

Turman, Jinny A., "Appalachian Alter-Natives: The Back-to-the-Land Migration and Community Change in Appalachia, 1970--2000" (2013). Graduate Theses, Dissertations, and Problem Reports. 254.

https://researchrepository.wvu.edu/etd/254

This Dissertation is protected by copyright and/or related rights. It has been brought to you by the The Research Repository @ WVU with permission from the rights-holder(s). You are free to use this Dissertation in any way that is permitted by the copyright and related rights legislation that applies to your use. For other uses you must obtain permission from the rights-holder(s) directly, unless additional rights are indicated by a Creative Commons license in the record and/ or on the work itself. This Dissertation has been accepted for inclusion in WVU Graduate Theses, Dissertations, and Problem Reports collection by an authorized administrator of The Research Repository @ WVU.

For more information, please contact researchrepository@mail.wvu.edu. 
Appalachian Alter-Natives: The Back-to-the-Land Migration and Community Change in Appalachia, 1970-2000

\author{
Jinny A. Turman
}

\begin{abstract}
Dissertation submitted to the Eberly College of Arts and Sciences at West Virginia University in partial fulfillment of the requirements for the degree of
\end{abstract}

Doctor of Philosophy in History

Kenneth Fones-Wolf, Ph.D., Committee Chairperson Elizabeth Fones-Wolf, Ph.D.

Melissa Bingmann, Ph.D.

L. Christopher Plein, Ph.D.

Paul Salstrom, Ph.D.

\author{
Department of History
}

\title{
Morgantown, WV
}

2013

Keywords: Back-to-the-land; migration; Appalachia;

voluntary simplicity; self-sufficiency; communes; smallholder; Floyd County, Virginia;

Lincoln County, West Virginia; counterculture; agrarianism

Copyright 2013 Jinny A. Turman 


\title{
Abstract \\ Appalachian Alter-Natives: The Back-to-the-Land Migration and Community Change in Appalachia, 1970-2000
}

\author{
Jinny A. Turman
}

Beginning in the late 1960s and continuing through the 1970s, thousands of people migrated from America's cities to the countryside to establish communes and independent homesteads on small plots of land. By working the land they hoped to achieve autonomy, self-sufficiency, and closeness with nature. Cheap land, mild climate, beautiful scenery, and folk culture drew many of these predominately young, white, well educated, and affluent migrants to Appalachia. During the earliest years of the back-to-the-land migration suspicion and occasionally conflict surfaced as natives and newcomers navigated different lifestyle preferences and worldviews, for many of the back-to-the-landers, or "alter-natives," had identified with 1960s social movements or the counterculture. Reactions to differences softened somewhat as the in-migrants engaged in mutually supportive relationships with their native neighbors. The alter-natives also formed countercultural sub-communities in the mountains that provided emotional and physical support for what could, at times, be a trying lifestyle.

Many alter-natives eventually became involved with broader community initiatives that addressed economic, educational, and environmental problems. Through various campaigns they forged bonds with like-minded natives, although disputes sometimes occurred as their "cosmopolitan" visions for local development and environmental sensibilities clashed with local procommodity interests. Different notions of the meaning of community and perceptions of sense of place shaped these contests. Both parties wanted to nurture community, but to many natives that meant preserving the traditional social structures and kinship networks that existed prior to the back-to-the-land migration. To many alter-natives community meant preserving the environment in which those exchanges occurred. Sometimes the clashes resulted in "outsider/insider" distinctions but they also brought diverse groups of individuals together.

Scholars who study the back-to-the-land movement have generally overlooked the impulse for community that existed alongside the desire for autonomy. Using Floyd County, Virginia, and Lincoln County, West Virginia, as case studies, this dissertation analyzes the in-migrants' integration into Appalachia and the broad effects they had on the region's social, political, and economic landscape. So the story of Appalachian alter-natives is the story of the search for community, of the push to reclaim - or preserve-interpersonal connections that provided support, grounding, and identity for multigenerational and new residents in rural Appalachia. 


\section{Dedication}

The author dedicates this work to the memory of her mother, Jeanie Turman, and to her late grandparents Eunice Yeatts McAlexander, Elkanah McAlexander, and Doris Turman. 


\section{Acknowledgements}

When I first entered the graduate program in history at West Virginia University, people cautioned me that I would grow tired of my project by the time I completed the dissertation. In no way has this happened, and I attribute my ongoing interest in the back-to-the-land movement to the hundreds of wonderful people I have met during my investigation. Oral histories serve as an important component of this research, and the Appalachian residents who have allowed me into their lives have enlightened me, inspired me, and deepened my understanding of the region's complexity and richness. I am indebted to so many people that I cannot name them all here, but they should know that their stories have touched my life and that I sincerely hope that this study represents them well.

Several natives and alter-natives devoted significant amounts of time to my research by introducing me to people, reading and commenting on my work, and providing me with additional resources. Paul Salstrom, one of my first interviewees and a dissertation committee member, has served as both mentor and guide. He has been involved every step of the way and was always willing to make comments, send materials, and to provide additional context for my work. He also encouraged me to publish an early seminar paper on the back-to-the-land movement. His family members, particularly his brother John and sister-in-law Jan, were also extremely helpful. Both sat for interviews and made themselves available to answer questions and provide feedback. Others who I would like to thank for connecting me to additional interviewees or providing me with resources include Susan Mead, Barbara Weaner, Phyllis Baxter, Melody Cochran, and Mack Samples. Lincoln Countians who offered me continued guidance include Jim Chojnacki, Julian Martin, and Ric MacDowell. Floydian alter-natives Colleen Redman, Jayn Avery, Fred First, Jason Rutledge, and the Bason family have been particularly helpful, and I would like to extend a big thank you to Floyd natives Wanda Vest and Lydeana Martin for their assistance as well.

Several institutions provided support for this research. Many thanks to the staff at the Jesse Peterman Memorial Library in Floyd, Virginia, for their ongoing guidance as well as the staff at the Lincoln County, West Virginia, courthouse for letting me take up valuable space in 2012. Thanks to my dear friends Fred Hay and Dean Williams at the W.L. Eury Appalachian Collection at Appalachian State University in Boone, NC, for their assistance and encouragement. I would also like to thank John Cuthbert and his staff at the West Virginia and Regional History Center at West Virginia University. I am equally grateful for the assistance I received from Greg Carroll at the West Virginia State Archives in Charleston; Lisle Brown, Kathleen Bledsoe, and the staff at the Special Collections at the Morrow Library at Marshall University in Huntington, WV; Marilyn Thielman, Donald Pitzer, and Jennifer Greene at the Center for Communal Studies at the University of Southern Indiana; my friend and fellow Appalachian Studies graduate Simms Toomey at the Southern Folklife Collection at the University of North Carolina, Chapel Hill; William LeFevre at the Walter P. Reuther Library at Wayne State University; and Phillip Runkel at the Department of Special Collections and 
University Archives which are part of the Raynor Memorial Libraries at Marquette University. These individuals turned what at times felt like an overwhelming research task into an enjoyable and rewarding process.

Funding is necessary for resesarch but it also provides validation of one's work. I am grateful for the financial support I have received through the years. The office of Graduate Education and Life at West Virginia University funded my early research through the Arlen G. and Louise Stone Swiger Doctoral Fellowship. The stipend enabled me to get a head start on the project by relieving me of teaching duties during my three years of coursework. The WVU Foundation's Distinguished Doctoral Fellowship provided me with financial support for an additional semester to conduct research. The Foundation, along with the Eberly College of Arts and Sciences and the Department of History, has continually supported my work by providing money for conferences and research trips. This study, with all of its oral histories, would have been impossible without such support.

Members of the Appalachian Studies Association and Society of Appalachian Historians have helped me to refine my research and have highlighted new avenues of consideration. Every time I attend those conferences I receive valuable feedback from participants and obtain fresh ideas for my research. Along similar lines, I must thank Patricia Beaver, David Sutton, Thomas McGowan, Helen Lewis, Fred Hay, Cece Conway, and the rest of my professors at Appalachian State University for igniting my passion for knowledge and opening my eyes to injustice. It is my sincere hope that this study will operate in the good old Appalachian Studies way by bridging the gap between academia and regional communities and that it will be useful to people confronting difficult community dynamics and trying to navigate change.

West Virginia's Department of History has been my academic home for the last six years, and I have always felt nurtured and encouraged there. My adviser, Kenneth Fones-Wolf, has been the perfect guide for me during this process; he has kept me on task, listened to my ideas, provided crucial feedback, and encouraged me every step of the way. Elizabeth Fones-Wolf has worked so hard to ensure that I have all of the resources-financial, emotional, social, and more- that I need to be successful; I am forever in her debt. I am equally grateful to Melissa Bingmann for her positive feedback and friendship, and I credit her for inspiring me to put a public historian's twist on this study. I am grateful to the other scholars who have encouraged me along the way either through coursework or good conversation: Joseph Hodge, Barbara Rasmussen, Greg Good, Robert Maxon, Katherine Aaslestad, Ronald Lewis, and the late Larry Sypolt, who is sorely missed. I often wonder what I (or the history department) would do without Martha May and Becky Warnke; their knowledge of the inner workings of the university and ability to make things happen is nothing short of miraculous. And although he is not in the history department, I would also like to express sincere thanks to another committee member, L. Christopher Plein of Public Administration, for his interest in and enthusiasm for this project. I look forward to many more conversations about Floyd and “Appalachia.” 
On a personal note, I must thank my friends, classmates, and family members for their ongoing support. Past and present graduate students in G-13 Woodburn Hall—Adam Zucconi, Jake Ivey, Fabio Capano, Blake Perkins, Ginny Young, Allison Fredette, Krista McCart, Christine Regier, Stephen Santelli, David Goldberg, Brandon Williams, Jay Smith, and Joel Christenson - have made me laugh and think and have graciously endured my coffee-induced chattiness. The same goes for the rest of my classmates: Josh Howard, Joe Rizzo, Jamie Blake, Hal Gorby, Zoa Williams, Angie Sirna, Nik Githuku, Josh Esposito, Isaac Emrick, Crystal Wimer, and Ben Scharff. Collectively they have made this journey a joy and I am grateful for the many memories I share with them. Special thanks to Lynn Stasick for his willingness to share his life story with me and for his friendship, compassion, and undying interest in history. Lynn is such an inspiration. Equally inspiring is Lou Martin, who has undergone his own personal transformation in recent years by dedicating his life to fighting injustice in the Appalachian coalfields. Thanks to Lou for reading my work, for listening, and for inspiring me to keep fighting the good fight. My sisters in history, Karina Garcia, Kat Fichtel, and Shannon Tinnell, have supported and encouraged me over the last six years; their friendship means the world to me and I cannot imagine my life without them. I am equally grateful for the women who have known me the longest and have continued to provide me with both emotional support and comedic relief: Stacey Kinney, Jenny Trull, Karen Delozier, and Sarah Deans. Words cannot express how deeply grateful I am to Rick Deal for the personal sacrifices, encouragement, and guidance that he provided for me both prior to and during my enrollment in graduate school. I would not be at this point without him. I am forever indebted to my family_Alex and Andrew Turman, Emra Hopkins, Ashley Allemann, Michelle Turman, and my aunts and uncles-for their support and for creating an environment that encouraged intellectual discussion and inquery. My deepest gratitude goes to my dad who believed in me and never failed to help me when I needed him the most, and to my dear grandmother, Nettie Turman, who long ago called my attention to the alter-natives living in Floyd. 


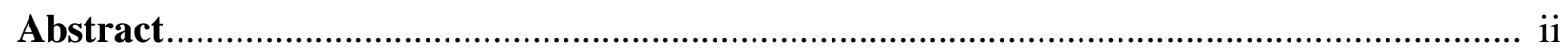

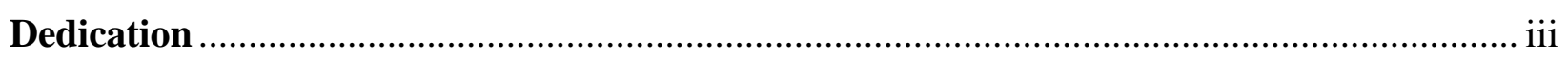

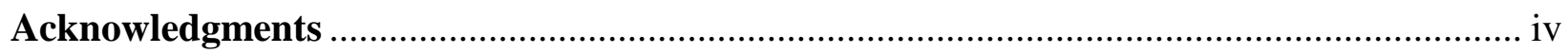

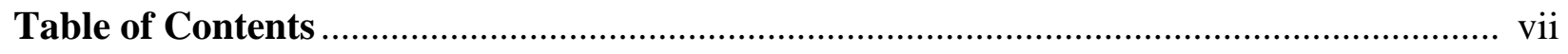

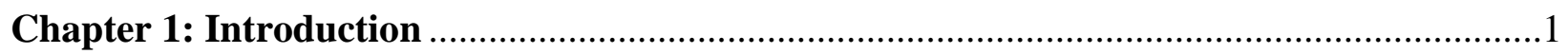

Chapter 2: From Inner City Chaos to "Mysterious Mountains ........................................29

Chapter 3: "Sane and sound and working counterculturalists" .......................................82

Chapter 4: “Where 'Howdy' and 'It's far out to see you' meet and shake hands”............134

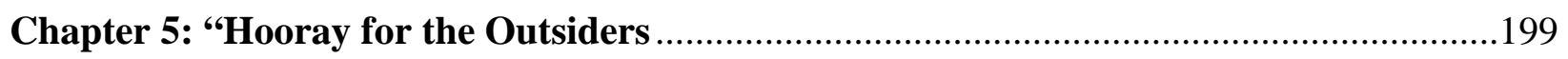

Chapter 6: “Economic Growth or Economic Justice?” .................................................266

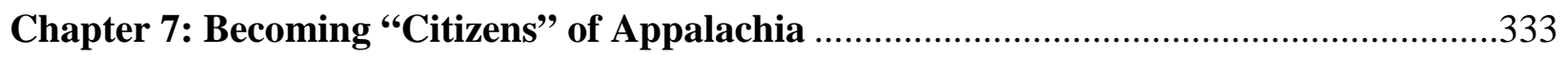

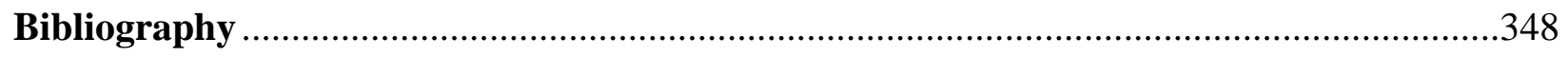




\section{Chapter One}

\section{Introduction}

We all miss our home villages and our tribes. We all long to belong and miss the clans and extended families we evolved in and the social safety net they naturally provided. We feel culturally dislocated because we are! dis located, having lost our connection to our localities in the cultural maelstrom of modern, global civilization. We become fans of sports teams with animal totems and join all manner of organizations looking for the mutual support network we remember on a cellular level, lack of it manifests as psychological stress and pervasive dis ease. Not having such a network often puts unbearable strain on marriages or other supportive relationships we do have.

We will return to a grounded small community level of social organization, and renew our bonds with the natural world. It is just a question of time, and this time we will be within the framework of global civilization and our communities themselves will have such a supportive network as well as ourselves as individuals. The kindness and inclusiveness we once reserved for our own kind will naturally expand to all humankind, and we will be finished with the terrible waste and sad business of war, it having served its purpose.

Will Bason,

Facebook status update

June $15,2012^{1}$

\footnotetext{
${ }^{1}$ Will Bason’s Facebook page, accessed June 15, 2012, http://www.facebook.com/will.bason.1. This quote was used
} with the author's permission. 
Will Bason first visited Floyd County, Virginia, in the spring of 1971 to investigate a piece of land for sale that had been advertised in a North Carolina newspaper. He and his mother, Ruth Bason, wanted to leave behind their native Raleigh to establish a self-sufficient, spiritual commune somewhere in the Appalachian Mountains. It was the height of the Vietnam War, and Bason and his family "had gone hip.” Their growing disaffection with the conflict and deepening interests in New Age spirituality, including the prophecies of clairvoyant Edgar Cayce, who pinpointed the ancient mountain range as "safe" in the face of "earth changes" that would someday alter the United States' eastern coastline, compelled the Basons to move "back to the land.” With countercultural and homesteading handbooks like the Mother Earth News and Whole Earth Catalog in hand, they set out to live simply. Bason's mother, who had separated from Will's father, "had some money to buy a place," so they looked for land in western North Carolina. Not finding anything to their liking, they continued their search until Bason spotted an ad for a piece of land in Floyd that "stood out." The description impressed him, but his family was skeptical "because they said it was too damn cheap." Not giving up, he convinced them to travel the one hundred and seventy miles up to Floyd in spite of their reservations, and the trip ultimately changed their minds. Bason remembered visiting on a "magic day ... just this really nice, early spring day.” He and his family experienced feelings of "a really strong spiritual bond” to the area and to that particular piece of land, so they purchased the one hundred acre tract—and with it, a cow, tractor, and old farmhouse-for roughly $\$ 10,000$. They named the commune Travianna, and it became one of the main avenues through which hundreds of hip youngsters, spiritual seekers, hitchhikers, and homesteaders discovered Floyd County. ${ }^{2}$

\footnotetext{
${ }^{2}$ Will Bason, interview by author, Floyd, Virginia, September 25, 2011; Wanda Vest, interview by author, Floyd, Virginia, August 5, 2011.
} 
The scores of young people who eventually visited Travianna were but a small fraction of a much larger urban to rural migration that started in the late 1960s. Over the following decade, thousands of people migrated from America's cities to the countryside to establish communes and independent homesteads on small plots of land. ${ }^{3}$ Some estimates place the number of migrants as high as several million. For the first time since the 1820s, growth in rural areas outpaced America’s cities. A “rural migration turnaround” was in full swing. Young, largely white middle-class baby boomers who had once swelled the ranks of antiwar protests on college campuses or in Washington D.C., participated in Stephen Gaskin’s “Monday Night Class” in San Francisco, had felt the blunt force of policemen’s rifle butts in Chicago in 1968, or had attended peace walks across portions of the United States found refuge from the era's social and political firestorms in rural America. Not all of the migrants were "movement” veterans; the broader demographic shift encompassed a mix of suburbanites, “quality of life” migrants, including retirees, who wanted the "grass and trees and clean air" minus the burden of agriculture, and others who followed industrial labor to the Sunbelt South. ${ }^{4}$ But a large percentage was composed of people who sought to continue the revolution, albeit in a quieter, more introspective manner: by rejecting mass consumption in exchange for a sustainable life centered on nature and the home. They returned to the land in search of themselves but also with an eye toward reform.

In the initial years of the migration, homesteaders and communitarians planted gardens, worked their property with draft animals, kept goats, built cabins, held potlucks and seasonal

\footnotetext{
${ }^{3}$ Merlin B. Brinkerhoff and Jeffrey C. Jacob, “Quasi-Religious Meaning Systems, Official Religion, and Quality of Life in an Alternative Lifestyle," Journal for the Scientific Study of Religion 26, no. 1 (March 1987): 64; Eleanor Agnew, Back from the Land: How Young Americans Went to Nature in the 1970s, and Why They Came Back (Chicago: Ivan R. Dee, 2004), 6-7. Even more remained in urban areas but scaled back their spending, reflecting a growing nationwide concern that consumerism had damaged America culturally, economically, and environmentally.

${ }^{4}$ Tom Morganthau and Frank Maier, “America’s Small Town Boom,” Newsweek July 6, 1981; Todd Gitlin, The Sixties: Years of Hope, Days of Rage (New York: Bantam Books, 1987), 428.
} 
festivals, established food co-operatives, raised children, canned, produced crafts, and sawed copious amounts of wood. In choosing a life defined by hard, physical labor and proximity to nature they hoped they could forge a new world order, one based on sustainability and voluntary simplicity rather than consumption and bureaucracy. Their embrace of Eden as a remedy for social ills was nothing new; returning to the countryside had long been advocated as a means to restore autonomy, cultivate character, reshape identity, and provide grounding for practitioners. Indeed, the 1970s-era back-to-the-land movement drew upon a variety of historic impulses: Jeffersonian agrarianism, the construction and interpretation of nature as divine, the Protestant work ethic, and antimodernism. Environmental concerns did set this most recent generation apart from their predecessors. ${ }^{5}$ As such, their labor resulted from an amalgamation of beliefs that coexisted, sometimes uneasily, in society regarding individual prerogatives and liberty, on the one hand, and broader social and environmental concerns on the other.

Independence was a powerful undercurrent propelling the back-to-the-land movement. Eleanor Agnew, who wrote a semi-autobiographical book explaining why most of the back-tothe-landers eventually came back from the land, observes the undying reverence for the pioneer in American society and what that archetype meant to her generation: "Veneration of pioneers, explorers, and early frontiersmen, another enduring thread of our cultural heritage, added a delightful spirit of heroism to our mission.” Early twentieth century back-to-the-land accounts enjoyed renewed attention from her generation by promising Five Acres and Independence. And

\footnotetext{
${ }^{5}$ Rebecca Kneale Gould, At Home in Nature: Modern Homesteading and Spiritual Practice in America (Berkeley: University of California Press, 2005), 3; Dona Brown, Back to the Land: The Enduring Dream of Self-Sufficiency in Modern America (Madison: University of Wisconsin Press, 2011), 11.
} 
a new wave of homesteading literature, including Farming for Self-Sufficiency, made the simple life seem all the more possible. ${ }^{6}$

In reality, though, many young baby boomers who followed the dream of owning their own small farmsteads found the experience wanting. The physical labor was hard—and sometimes nearly impossible depending on the task—and social isolation maddening. One would-be homesteader, Paul Salstrom, confessed in 1967 that he had briefly considered relocating to rural Maine. After all, homesteading luminaries Helen and Scott Nearing and Bill Copperthwaite found deep satisfaction eking out a living in the state's coastal region and, in the 1960s and 70s, welcomed steady streams of visitors because of their successes. But the "lack of love and laughter” in the region’s “bleak hills” deterred Salstrom from settling there. He feared that "going it alone" there would lead to a life, in the words of another author, of "monotony or drudgery and loneliness.” The hills around San Francisco better suited him because they offered an abundance of social opportunities and "stimulation.”7

While the era's official movement literature may have celebrated independence, particularly in the face of seemingly overbearing social and political structures, the impulse for community was never far beneath the surface. Both Bason's and Salstrom's observations suggest that many individuals, at least of their generation, suffered without social supports from larger communities that could provide “meaning, a sense of belonging, and well-being” for their citizens. Baby boomers struggled with a lack of identity that resulted from demographic shifts and the decline of traditional neighborhood and familial support networks. Social scientists lent weight to the perception that increased bureaucratization undermined small community

\footnotetext{
${ }^{6}$ Agnew, 10-12.

${ }^{7}$ Paul Salstrom, “On Going it Alone,” Green Revolution, April 1967.
} 
autonomy. ${ }^{8}$ To restore the individual, then, small communities needed to be restored. "Artificial” communities often replaced “natural” communities; communes, civic leagues, and even Bason’s "sports teams with animal totems" bonded together America’s uprooted masses. In areas where enough people established communes and homesteads to live off the land, new sub-communities eventually formed, filling the void that had caused "psychological stress and pervasive dis ease.” ${ }^{9}$ Responding to postwar concerns about the deterioration of extended family and communal networks in America, then, back-to-the-landers sought to restore humankind's relationship to nature as well as the "traditional values" of "family, home and community."10

Going back to the land was about self-actualization and what the experience of physical labor and proximity to nature could do for the individual. But in areas like rural Maine or, for the purposes of this study, Southern and Central Appalachia, "going it alone” was nearly impossible. The myth of self-sufficiency and independence aside, it also became, for many, undesirable. Those who tried to be independent—and many did—quickly discovered that in order to survive the physical and emotional stress of the lifestyle, they had to reach out to neighbors. It was through those connections that back-to-the-landers began to form sub-communal and communal networks with their native neighbors and like-minded individuals who surrounded them. The focus of this study then is to examine the push for community and the process through which the back-to-the-landers became—or are still becoming — part of their adopted areas' social landscape.

\footnotetext{
${ }^{8}$ Emilia E. Martinez-Brawley, Perspectives on the Small Community: Humanistic Views for Practitioners (Silver Spring, MD: National Association of Social Workers Press, 1990), 50-51, 8-11.

${ }^{9}$ Will Bason’s Facebook page, accessed June 15, 2012, http://www.facebook.com/will.bason.1.

${ }^{10}$ Morganthau and Maier, “America’s Small Town Boom.”
} 
Appalachian Alter-Natives:

Homesteaders and communitarians migrated in clusters to the Northeast, Pacific Northwest, Midwest, Southwest, and into Canada. Although they largely avoided the Deep South because of racism and violence that had been inflicted upon civil rights activists in the 1960s, certain portions of Southern and Central Appalachia proved to be very attractive because of the region's cheap land, mild climate, cultural heritage, proximity to the east coast's urban centers, and lush environment. ${ }^{11}$ They moved into mountain counties by the thousands, settling on old farms and up remote hollers. While many came to the region intending to be at least partially self-sufficient, they quickly found that life in rugged mountainous areas was fraught with hardship. The Appalachian region, like other rural areas, had been struggling for decades with poverty, poor infrastructure, lagging education systems, industrial abuses, and poor public health. In order to survive—and to stave off loneliness—-nuclear-family homesteaders and communitarians created alternative sub-communities in the mountains. Many also formed deep bonds with their native neighbors. Although a majority of the initial migrants who came in the 1970s did not remain permanently, a few dug in, supporting themselves through farming, the arts, multiple part-time jobs, or by commuting to county seat towns or larger regional cities for employment. As employees, as neighbors, and, eventually, as advocates for a number of political, economic, and cultural initiatives, they eventually became part of their communities' social fabric.

The back-to-the-landers in Appalachia were similar to those elsewhere. Writing in the 1980s, anthropologist Patricia Beaver observed that they "were generally well educated, having

\footnotetext{
${ }^{11}$ John Alexander Williams, Appalachia: A History (Chapel Hill: University of North Carolina Press, 2001), 353; Connie Ann Kirk and Dana L. Stuchul, "Back-to-the-Land Movement," in Encyclopedia of Appalachia, edited by Rudy Abramson and Jean Haskell (Knoxville: University of Tennessee Press, 2006), 295.
} 
started and usually finished an undergraduate degree, with a generous sprinkling of masters degrees and teaching certificates, and a few doctorates.” Most came from “middle class backgrounds ... had traveled fairly widely and had knowledge of urban life and political processes.” The new arrivals to western North Carolina also, she added, were at least intellectually connected to the counterculture, having been "well versed” in its "philosophy and rhetoric."12

Beaver's observations apply to many of the simple-life seekers who moved into West Virginia and Virginia during the 1970s. A majority of the people interviewed for this study were indeed young when they migrated, having been somewhere between the ages of eighteen and thirty years old. Most had received some form of higher education prior to migration, although there were several who had decided for one reason or another to drop out. (Quite a few of those folks eventually resumed their educations at regional institutions.) The vast majority, with a few important exceptions, came from urban or suburban areas in the Midwest, Northeast, or MidAtlantic states. Hardly anyone was originally from the West Coast, although many had visited and spent significant time in San Francisco and other hip locations. Many had been migratory before settling in the mountains. Almost all were white, although they did have different ethnic and religious backgrounds.

As for the in-migrants' association with the counterculture, some had been actively involved with antiwar efforts, while others simply held antiwar sentiments but never engaged in mass action. Many were socially-motivated and had advocated for causes related to human and environmental rights. Some, like Will Bason, openly embraced the "hippie” label that the media

\footnotetext{
${ }^{12}$ Patricia D. Beaver, Rural Community in the Appalachian South (1986; repr., Prospect Heights, Illinois: Waveland Press, 1992), 121.
} 
(and, eventually, their native neighbors) placed on them, while others resented the term. Still, most, at least while they were still young, embraced the hip ideals outlined in Timothy Miller's The Hippies and American Values. They had an affinity for nature, preferred rural over urban life, rejected the consumer culture, and were tribal, meaning that they typically desired membership in a larger community of like-minded people. ${ }^{13}$ When explaining why they decided to embrace voluntary simplicity, a number of them framed their story within the context of the era's social and economic turmoil, while others asserted that they had been on a spiritual journey, seeking a more grounded, meaningful existence than what they had left behind.

There are important exceptions to this demographic portrait, and at least one person voiced dissatisfaction with the application of "back-to-the-land" to the era's rural migration turnaround. Sustainable forester and homesteader Jason Rutledge was raised on a central Virginia farm, served in the military during the war in Vietnam, and moved to Floyd County, Virginia, after his service ended. Before agreeing to be interviewed, he asserted his position on the phrase "back-to-the-land." To him, it suggested that everyone from his generation who became homesteaders had at one time lived on a farm. To be a back-to-the-lander in the truest sense of the phrase, they would have been raised on farms, left those farms for the city, and eventually returned. According to one sociological survey of homesteaders that was published in the 1990s, a vast majority of back-to-the-landers operating in the 1980s and 90s had little to no prior farming experience. So in a sense, Rutledge is correct to criticize the phrase. ${ }^{14}$ But movement proponents and practitioners typically understood the phrase in light of human history; they saw themselves as people "reclaiming their place on the earth as descendants of

\footnotetext{
${ }^{13}$ Timothy Miller, The Hippies and American Values (Knoxville: University of Tennessee Press, 1991), 91-92, 112.

${ }^{14}$ Jason Rutledge, interview by author, Floyd, Virginia, July 21, 2011; Bason interview.
} 
ancestors who were themselves children of the land." ${ }^{15}$ In addition, scholars who study the movement see the 1970s-era back-to-the-land movement in terms of an atypical demographic trend, a reversal of the rural to urban migration pattern that dominated the $20^{\text {th }}$ century, rather than in terms of the movement of specific individuals. ${ }^{16}$ For that reason this study uses the phrase "back-to-the-land” but does so with the understanding that while it is problematic in the most literal sense, it more broadly represents a large-scale movement of people who believed they were reclaiming humankind’s agricultural heritage.

Rutledge's critique raises another important point about the difficulty of understanding the back-to-the-land population. What do we do, for example, with native Appalachian baby boomers who went to college, either in the region or elsewhere, and returned again to homestead? These individuals often became well acquainted with other countercultural newcomers in their communities and in some instances even married non-native back-to-thelanders. Another group included in this study is the countercultural baby boom contingent that moved to Appalachia in the 1970s and 1980s but did not homestead or live on farms. This included people who moved into Appalachian towns rather than the countryside, who rented apartments for a time, or who came directly to engage in non-farm labor. While native Appalachians often used "back-to-the-lander" as an all-encompassing term to describe any countercultural element that had migrated to their communities (along with "hippies,” “comeheres,” or the more derogatory “outsiders,” a term typically reserved for moments of conflict and not exclusively directed toward back-to-the-landers), this study employs the moniker "alternatives.” Will Bason's play on the word "alternative” encompasses all of the countercultural

\footnotetext{
${ }^{15}$ Jeffrey Jacob, New Pioneers: The Back-to-the-Land Movement and the Search for a Sustainable Future (University Park: Pennsylvania State University Press, 1997), 33-39.

${ }^{16}$ Jacob, 39.
} 
migrants who settled in Appalachia during the 1970s and 80s. It captures the spirit and essence of those people who moved, or returned, to Appalachia because of their disaffection with mainstream society and their desire to live sustainably and to find grounding and meaning in small community. The terms "homesteader" and "communitarian" will be used when necessary to differentiate between the two groups. ${ }^{17}$ "Alter-natives" will be used to describe countercultural migrants as a whole.

Alter-natives' dual notions of achieving independence and self-actualization, on the one hand, and restoring small, supportive communities, Gemeinschaft, on the other, shaped their eventual integration into Appalachian communities. Most came with illusions about what living self-sufficiently could do for them as individuals, although the first crop- the true pioneers of the lifestyle—may have espoused the most extreme idealism. ${ }^{18}$ Baby boomers had romanticized the nation's "outsiders," people living on the economic margins, believing those folks to be more grounded and rooted in authentic experiences. This contrasted with the seemingly fake, plastic, and artificial characteristics of popular society. Appalachian farmers, for one, were viewed as authentic, and by remaking themselves as part of the rural poor, the baby boomers hoped to

\footnotetext{
${ }^{17}$ Rutledge interview; Bason interview. A number of anti-poverty workers also settled in the region, and some, like Lincoln County alter-native Ric MacDowell, wound up living on small farmsteads after their service. In light of Thomas Kiffmeyer's fine study on Appalachian antipoverty workers, this study will not consider these individuals at length; rather, they will only be examined when specific individuals who came as part of that initiative remained and sought to live sustainably on the land. Still, the catchall term "alter-native" could easily apply to them as well, as they often had social ties with back-to-the-landers and shared similar political and environmental views. See Thomas Kiffmeyer, Reformers to Radicals: The Appalachian Volunteers and the War on Poverty (Lexington: University Press of Kentucky, 2008).

${ }^{18}$ For information on illusions and "quality of life" migrations, see Patrick C. Jobes, Moving Nearer to Heaven: The Illusions and Disillusions of Migrants to Scenic Rural Places (Westport, Connecticut: Praeger, 2000); Beaver, 130. Patricia Beaver contends that subsequent in-migrants were more pragmatic about the back-to-the-land lifestyle, reflecting perhaps increased awareness of the difficulties of homesteading that were published in popular movement literature like Mother Earth News.
} 
cultivate a more meaningful and fulfilling life. ${ }^{19}$ From the movement's onset, many genuinely believed in their abilities to be self-sufficient, but rare was the homesteader who could actually make it on his or her own. Those who staked out plots of land in remote sections of Appalachia quickly realized that in order to survive, they had to establish connections with their native neighbors who had the necessary knowledge and skills to survive. The irony is that the alternatives' integration into neighborhood social networks often resulted in their having to curb expressions of the liberated countercultural lifestyle, as Patricia Beaver notes, and caused them to have to navigate different notions of the meanings of "community" and "individuality."20

Alter-natives’ experiences in Appalachian communities varied according to time and place. The two communities examined at length in this study, Floyd County, Virginia, and Lincoln County, West Virginia, offer a window into the wide range of economic, social, and political circumstances that shaped in-migrants' lives. ${ }^{21}$ Appalachia has long been portrayed as a region with a unified and homogenous folk culture, but this understanding clouds the reality of the vast sub-regional differences and worldviews that exist. At the movement's onset, the two counties looked remarkably similar; both were bedroom communities to college and larger towns, were primarily agricultural, and had experienced significant outmigration following

\footnotetext{
${ }^{19}$ For consideration of the baby boom generation's romanticization of outsiders, see Grace Elizabeth Hale, A Nation of Outsiders: How the White Middle Class Fell in Love with Rebellion in Postwar America (New York: Oxford University Press, 2011).

${ }^{20}$ Beaver, 126.

${ }^{21}$ I selected Floyd County as a case study in part because of my familial connections to that community and in part because of the dramatic changes that have occurred there over the last forty years. Lincoln County came to my attention very quickly after I enrolled in the doctoral program in history at West Virginia University. Paul Salstrom, an economic historian who purchased land there in the early 1970s, wrote one of the first articles I read on the subject. In it, Salstrom estimated that between three and four hundred people had moved to the county as part of the back-to-the-land movement. Most of those people have since left, with the exception of several dozen holdouts, and if one visits the county seat of Hamlin, the signs of the alternative community's influence are not visible. This is a dramatic contrast to Floyd, where there are a variety of stores and restaurants that signal countercultural presence in the county. Alter-natives in Lincoln left their mark on the county to be sure, but the results are less visible. Reasons behind this will be explored in depth in Chapters Five and Six.
} 
WWII. But they also had a few key differences that grew increasingly salient after the 1970s. Floyd's proximity to the Blue Ridge Parkway helped that community tap into the growing heritage tourism market. Regional support for such initiatives made it easier for local leaders to recognize tourism as a viable industry. Lincoln, on the other hand, while not traditionally a heavy coal producer, is still situated within the southern coalfields. Many Lincoln residents were thus dependent on the coal industry for employment even though they may have had to commute out of the county for work. Lincoln County traditionally supported a number of coal's auxiliary industries like timbering for mine props. The county’s geographical position fostered a political culture reliant almost exclusively on resource extraction. The county had also long hosted a corrupt political regime, reflecting broader state tolerance of corruption and collusion with outside corporate interests. These community characteristics need to be considered as they shaped the level of tolerance that both elite and non-elite locals exhibited toward alter-natives in the wake of the back-to-the-land migration.

Even though Floyd and Lincoln feature prominently in this study, particularly in the latter chapters that examine alter-natives' participation in various local initiatives, other accounts will be considered to either highlight shared experiences or provide counterpoints to generalizations. Alter-natives from Virginia, West Virginia, and elsewhere can shed light on whether or not the experiences of those in the two case studies were typical or unique. It stands to reason that each community’s history, subculture, and political economy exacted influence on how established residents received alter-natives and how the two groups integrated over time. The study will also consider some state and national forces that had local implications, particularly related to political cultures and economic development. 
Will Bason, with his vision for restoring small communities centered on the natural world, was, along with his mother Ruth, integral to the process of cultivating the alternative subcommunity in Floyd. By welcoming people seeking self-actualization into Travianna (the only condition being that they had to inform their parents of their whereabouts), they helped to form the nucleus of a strong sub-community that exists in the town to this day. Other communes in Floyd served similar purposes, although they were often more insular than Travianna. Alternatives there used media, rituals and celebrations, and word of mouth to recruit like-minded people; they actively supported others who came there in search of the agrarian dream. Over time, Floydian alter-natives formed a collective identity that celebrated their cultural uniqueness, earth-based and eclectic spirituality, and disaffection with mainstream society, although subsequent waves of back-to-the-land and countercultural types did not necessarily foster uniformity in values or ideals. That sub-community at times experienced conflict because of the diversity of ideas and attitudes that existed about the meaning of sustainability and competing notions of independence and community. They also had to navigate a similar range of ideas among the local population.

In the early years of the back-to-the-land movement, it looked as if Lincoln County's alter-natives might have achieved similar results. Several hundred back-to-the-land migrants came to that community in the 1970s; the county's population experienced a whopping twentyfive percent increase during that decade. The movement there was composed mostly of nuclearfamily homesteaders. Some had lived communally prior to their move to the county but rejected that lifestyle because of interpersonal conflicts and the constant flow of people that troubled many of the era's collectives. One exception was a Catholic Worker farm in the county that was established in 1969 to promote social justice for impoverished Appalachians through 
sustainability. Beyond that, the migration resulted from cheap land, publicity, and word of mouth. A strong sub-community formed in the early 1970s - this study includes lively accounts of homesteaders' work parties and other support networks that fostered social capital, which in turn helped the in-migrants forge powerful grassroots opposition to unwelcome forms of development-but failed to flourish because of the county’s corrupt political structure that resulted in a deficiency of services that might otherwise have promoted a higher quality of life for residents.

Independence or Community: Considering the Literature

Anthropologist Patricia Beaver admitted that when she began her doctoral research in the western North Carolina community of "Rocky Creek," she approached the project with many of the same perceptions of Appalachian folk culture as were presented in popular culture at the time. She believed that Appalachia hosted "the old-timey, quaint . . . independent farm family in a farm community, familiar with old songs and sustained by older cultural traditions,” and this belief led her to, at least initially, eschew local residents who did not fit that image. However, she was introduced to her community through friends, "newcomers," who had migrated to Appalachia to homestead. Beaver reluctantly included them in her study in a chapter titled “Foreigners.” In doing so she analyzed the process through which alter-natives integrated, albeit somewhat awkwardly, into regional communities and engaged in local networks of reciprocity and sharing. Beaver discovered that the earliest homesteaders had the most highly developed illusions about homesteading’s potential for independence and personal liberty. But they quickly_-within a year or so—realized the folly of their vision. Self-sufficiency was “a 
chimera," as Paul Salstrom later wrote, and to survive they had to rely on their native neighbors. ${ }^{22}$ Increased social interaction with natives meant that they had to curb expressions of personal liberation, at least while in public or their neighbors' presence. But over time, as additional in-migrants arrived, they relied less on native support and more on the support of the emerging countercultural sub-community.

Beaver's study is crucial for understanding alter-natives' earliest years in the mountains, for it reveals the complex negotiations that occurred as a result of interaction between the two groups. Other studies do not go nearly as far in terms of analyzing community relations, but they do illuminate back-to-the-landers' value systems that eventually factored into relationships as well as important historical threads that informed the 1970s-era movement. Jeffrey Jacob, the author of a sociological survey of back-to-the-landers, contends that the back-to-the-land vision for people typically started with the promise of independence, although there were more sociallymotivated reasons for engaging in voluntary simplicity. The act of being self-reliant had the potential to impart upon practitioners a deep sense of satisfaction. However, he, like other scholars who analyze the movement, observed ambivalences about this goal. Many homesteaders quickly realized that their pursuit of "freedom" through self-sufficiency in effect actually limited freedom, for the demands of farmlife, coupled with severely limited incomes restricted their movements and activities. But Jacob also observed a "communal spirit" and social reform mindset that existed, although perhaps secondarily, alongside the desire for personal fulfillment through self-sufficiency. "The attractions to the simple life come from seemingly polar extremes," he observes, "the desire for inner peace and the desire for world peace."23

\footnotetext{
${ }^{22}$ Paul Salstrom, “The Neonatives: Back-to-the-Land in Appalachia’s 1970’s,” Appalachian Journal 30, no. 4 (Summer 2003): 319.

${ }^{23}$ Jacob, 86-87, 93, 96.
} 


\section{Dona Brown's Back-to-the-Land: The Enduring Dream of Self-Sufficiency in Modern}

America, demonstrates that there was a variety of motives undergirding historic back-to-the-land impulses as well as a multitude of approaches. She identifies important similarities and differences that existed between the baby boom generation's movement and earlier back-to-theland movements. The baby boom back-to-the-land contingent was generally the same as before—-white-collar urban- and suburbanites—and they decried the "rat race," city life, and materialism with as much, or even more, vigor than their predecessors. The differences, asserts Brown, were that they were willing to completely sever ties with the suburbs (earlier back-tothe-land advocates had touted suburbs as a healthful alternative to city living), they espoused heightened concerns for the environment and energy shortages, and they were more adamant about reclaiming personal independence than earlier simple life advocates. Their emphasis on independence was in part a reflection of their affluent backgrounds that afforded them the opportunity to reject mass consumption, but it was also possibly the result of "the Great Society's 'safety nets'” that could cushion them in lean times. Either way, they seemed to be less concerned about losing regular paychecks. ${ }^{24}$

Brown also observes that throughout the twentieth century there have been as many concepts of how to implement the simple life as there have been reasons for promoting it. "Producers of the back-to-the-land dream," she contends, "did not always see eye to eye with its 'consumers."” Simple life "consumers" generally sought independence first and foremost; men and women, and people of all religious and ethnic backgrounds, wanted self-sufficiency because of their desire for autonomy, "for independent proprietorship, for a buffer" against economic fluctuations, and "for a modicum of security in old age." But others advocated going back to the

\footnotetext{
${ }^{24}$ Brown, 209-212.
} 
land as a measure of social reform. They supported the ideal of independence, but themes of social control, cultivating collective identities and personal fulfillment, and economic reform likewise informed their support for a return to small-scale farming. Some people promoted small-scale agriculture for poor immigrants, for example, in the hope that they could become self-sufficient and adopt American-style independence, while others dreamed of removing themselves from the doldrums of white-collar work and the eyes of watchful bosses and living life unfettered in rural America. ${ }^{25}$

Another study, Rebecca Kneale Gould's At Home in Nature, analyzes homesteaders in a religious context; she tries to understand the movement as an expression of a lived religion through the construction of nature as “sacred, beneficient, and redemptive.” Like Brown, she examines the historical threads that connected Thoreau to Helen and Scott Nearing and, subsequently, to modern day homesteaders, arguing that they sought meaning and purpose in the natural world. They did this by "collapsing the divide between professional and personal" and centering their lives on the home and its place in nature. Homesteaders' nature-based spirituality is often presented and understood as being oppositional to mainstream American religious traditions, but she contends that their religiosity still operates within much the same parameters. She discovers, for example, that many homesteaders have "conversion” narratives that explain their decisions to reject the dominant culture in favor of simple living. They also ritualize daily activities that become infused with meaning because they serve to reconnect the individual with nature, which is what they view as the cornerstone of morality. Modern homesteaders' labor on the land purifies and cleanses them of the sins of materialism and consumption even as it exposes the limits of what they can accomplish on their own. Gould also analyzes their motivations for

\footnotetext{
${ }^{25}$ Brown, 9-11.
} 
homesteading, their expressions of belief in (a romanticized) agrarian past and in humankind's relationship with nature, and their ambivalences toward the lifestyle. Her study is particularly important for understanding what drove homesteaders and communitarians to embrace asceticism and how they infused meaning into their daily activities. ${ }^{26}$

Adding to our understanding of the limitations of the back-to-the-land movement and practitioners' ambivalences about the lifestyle is Agnew's Back From the Land. The movement ultimately failed because homesteaders realized that the lack of money, healthcare, leisure time, and intellectual stimulation might not be worth the peace and quiet of country life. Many began to desire the incomes and socialization that only urban areas could offer. Her study is incredibly insightful, as it draws from a number of personal accounts, including some from West Virginia, of struggles and hardships on the land. But questioning whether or not the movement was a failure may not be the most instructive point of analysis. As one reviewer observes of her book, "she reaches no definite conclusions about what our culture can and should learn from the experiment." ${ }^{27}$ Questions remain about the interaction between back-to-the-landers and "locals": the relationships that were built, the conflicts that ensued, and local or regional changes that took place as a result of the migration. Will Bason's concerns about reclaiming community suggest that there was something more to the movement than just asserting or maintaining, or failing to achieve, independence.

What is missing from these examinations of back-to-the-land movements is extensive consideration of the effects that the 1970s-era back-to-the-land movement, or, indeed, even earlier ones, had on host communities’ social, economic, and political landscapes. Beaver’s study

\footnotetext{
${ }^{26}$ Gould, 2-5, 66 .

${ }^{27}$ John Gatta, "Rediscovering the Earth,” The Sewanee Review 112, no. 4 (Fall 2004): 622.
} 
aside, most provide little more than glimpses of interpersonal relationships that were cultivated between natives and newcomers, ideas that were exchanged, opinions that were negotiated, or policies that were resisted or advanced. The overwhelming majority of homesteaders in Jacob’s study valued privacy over all else, even food cultivation, but about sixty percent had some community orientation. "While they are sympathetic to activist causes and are at times drawn into direct confrontation" with problems related to "rural underdevelopment, for the most part" homesteaders "direct their moral indignation inward, in an attempt to change themselves rather than the outside world." ${ }^{28}$ Yet Jacob finds most to be sympathetic toward activist groups. Roughly half actively support organizations that campaign for environmental justice. ${ }^{29}$ And of their relationships with people in their surrounding communities, Jacob indicates that the homesteaders in his study "fit quite comfortably within the rural communities they have chosen for their homes.” They appear to have a high level of satisfaction about their adopted communities and generally feel that they have been accepted by their native neighbors. ${ }^{30}$

Rebecca Gould dismisses the notion that homesteaders are predominately focused on the self and on personal independence or liberation; instead, she argues that they exhibit a broad commitment to concerns beyond the self. But she offers little analysis in terms of how broader concerns about the environment and social and economic justice translate to action on a community level. Homesteaders model sustainability, and sometimes even advocate for it publicly, but what does it look like when they organize grassroots environmental campaigns in communities accustomed to relying on natural resource extraction, for example, or attempt to implement their vision of economic decentralization in communities suffering from a lack of

\footnotetext{
${ }^{28}$ Jacob, 184-189.

${ }^{29} \mathrm{Jacob}, 179$.

${ }^{30}$ Jacob, 189.
} 
jobs and income? How was their involvement in local issues received, particularly during economic downturns that may have heightened anxiety in communities already plagued with economic problems?

One particularly useful article written by historian Sharon Weaver suggests that others are starting to ask similar questions about the back-to-the-land movement's impact on rural communities. How did different communities adapt and respond to the influx of migrants? Were they rejecting? Were they welcoming? Weaver investigates interactions between back-to-thelanders and established residents in several communities in Canada. She demonstrates that the communities experienced their respective "hippie invasions" differently. Cape Breton in Nova Scotia was generally more open and receptive to newcomers than three small islands in British Columbia because of the area's accessibility. In Cape Breton, newcomers bonded with local neighbors through shared occupations, particularly fishing, and their interest in the local folk culture. Weaver maintains that there was an air of "mutual respect [that] characterized their relations from the outset and left room for dialogue when divisive issues arose.” Newcomers to the western islands struggled because of the area's extreme geographical isolation; people could only leave by ferry, and this had fostered a very tight-knit, insular native community that had little tolerance for foreign ideals, values, or lifestyles. Particularly relevant for this study is Weaver's observation that integration into both areas became more fluid after 1975 and '76, when many of the "transient" hippies had left. After this point, some locals began to see back-tothe-landers as seriously committed to their communities, and integration became easier. ${ }^{31}$ This seems to have been the case in Floyd and Lincoln counties, as alter-natives either founded or joined indigenous grassroots efforts to stave off unwelcome forms of development.

\footnotetext{
${ }^{31}$ Sharon Weaver, "First Encounters: 1970 Back-to-the-Land, Cape Breton, NS, and Denman, Hornby and Lasqueti Islands, BC,” Oral History Forum d'histoire orale 30 (2010).
} 
A few sociological studies that focus on migrations, and particularly quality of life migrations, shed additional light on the question of integration into rural communities. Patrick C. Jobes’ analysis of in-migration to the Gallatin Valley in Montana explores the level of satisfaction — and dissatisfaction — that occurs following migrations that are often based on “illusions” or perceptions of an area rather than reality. "Most migrants to beautiful places have relatively inaccurate illusions about what the new community and their life within it will be,” he observes. $^{32}$ In-migrations to the area were often temporary because the new arrivals were ill prepared to navigate the realities of rural life. Many had little understanding of the social dynamics that existed within their new towns, and they also failed to anticipate the difficulties of living in geographically isolated and underdeveloped areas. Although his initial intent was to examine the levels of satisfaction and perceptions about quality of life among newly arrived residents in the valley's small communities, the study eventually morphed into a detailed analysis of why some migrants left and some ultimately decided to stay.

Jobes also considered what the implications were of those transitions on the community over time. He finds that the people who migrated into Gallatin Valley with highly developed illusions of its social and natural environment were the most likely to leave, and typically after only a short period of time. The fewer illusions that newcomers had of the area, the more permanent the move. "It became apparent," he recalls, "that those recent arrivals who intensely listed the beautiful environment, the friendly community, and the developed cultural resources as the sources of their future happiness were unintentionally waving a red flag that they were likely to be moving away soon." Those people's decisions to move were often based on "bad facts" about the area and general misunderstandings about the ways in which the environment and

\footnotetext{
${ }^{32}$ Jobes, 18.
} 
community could enhance their lives. High expectations often led to disappointment, and disappointment in turn prompted the in-migrants to move away. Those who had more modest evaluations of the area, coupled with more realistic visions of what they would do once they arrived, typically settled for longer periods of time. ${ }^{33}$

Illusions about what the back-to-the-land lifestyle could offer in terms of personal satisfaction and growth were common, and they ultimately spelled its demise. The 1970s-era back-to-the-land movement had peaked at mid-decade and largely ended by the mid-1980s, although, as Jacob’s study indicates, the movement picked up once again in the early 1990 s. $^{34}$ Vivid descriptions of the wonders of living close to nature and finding purpose and meaning in such mundane, daily tasks as cutting firewood or weeding that were presented in movement literature did little to prepare ex-urbanites for the hardships of rural life. The movement collapsed because homesteaders realized that the lack of money, healthcare, leisure time, and intellectual stimulation in rural areas was not worth the peace and quiet of country life. Many homesteaders longed for the incomes and socialization that only urban areas offered. Those who remained compensated for this by building sub-communities of their own and integrating into the broader community. In the process, they started to change the social, environmental, and, to a limited extent, political landscape in their new areas. ${ }^{35}$ Conflicts arose from competing notions of the meaning of rights, liberty, and community. At the same time, shared appreciation for sense of place and regional cultural heritage bonded residents together.

The implication of the 1970s-era back-to-the-land migration on small communities, then, is community change. With community change came conflict but also moments of cooperation.

\footnotetext{
33 Jobes, 19.

34 Jacob, 3.

35 Jobes, 210.
} 
While some alter-natives indeed found acceptance and identity in their new communities and forged bonds with like-minded natives and newcomers, disputes also occurred as people with “cosmopolitan” visions for local development and certain environmental sensibilities clashed with local actors interested in economic development at any cost. Different notions of the meaning of community and perceptions of sense of place shaped these contests. Both parties wanted to nurture community, but to many natives that meant preserving the traditional social structures and kinship networks that existed prior to the back-to-the-land migration, while to many alter-natives it meant preserving the environment in which those exchanges occurred. Sometimes these clashes resulted in "outsider/insider" distinctions, but on other occasions, they brought diverse groups of individuals together. ${ }^{36}$

So the story of Appalachian alter-natives is the story of the search for community, of the push to reclaim—or preserve—interpersonal connections that provided support, grounding, and identity for both multigenerational and new residents. Both groups feared dramatic community change, but how they articulated those concerns and sought solutions to the problem sometimes differed. Community also implied a geographical place situated within a physical environmentan environment that could either be preserved or exploited for personal gain—so the urge for community in that respect likewise forced residents to weigh the benefits and drawbacks of environmental protections versus job creation. It is through these dynamics that the challenges associated with migration surface: navigating different preferences, value systems, ideas, and motives and finding solutions agreeable to all parties so that they can, in fact, recapture at least

\footnotetext{
${ }^{36}$ Martinez-Brawley, 26-43.
} 
the essence of "the clans and extended families we evolved in and the social safety net they naturally provided.”37

\section{Chapter Overview:}

Relying on existing scholarly studies of the 1970s-era back-to-the-land movement, community studies, and a spate of analyses of quality of life migrations, this study will examine the integration of countercultural migrants, or “alter-natives,” into Floyd County, Virginia, and Lincoln County, West Virginia. What it offers is consideration of the implications of the movement on rural communities. A form of cultural syncretism occurred in Appalachian communities that hosted significant numbers of countercultural in-migrants, although not without certain degrees of conflict or pain on the part of both long-term residents and newcomers. Community integration and change was a slow, and often contested, process. Disagreements arose not only between natives and newcomers but also, in Floyd, between different generations of newcomers. Because the movement was inherently political, in spite of “escapist” appearances, the alter-natives who opted to remain long-term sought to implement their visions of sustainability and self-sufficiency on their broader communities. But in the process, they had to negotiate and adjust their values and expressions of independence and liberty. Even so, they made their mark on the social, political, and economic landscape by contributing human capital and cultivating social capital through various groups and organizations that allowed them to exchange ideas and develop strategies for confronting Appalachia’s problems. They injected new dialog and energy into regional communities, formed

\footnotetext{
${ }^{37}$ Will Bason’s Facebook page, accessed June 15, 2012, http://www.facebook.com/will.bason.1.
} 
community-based organizations, cultivated alliances with like-minded natives, and challenged the political status quo. Their success depended on a variety of factors, including community cohesion during developmental debates, political tolerance, economic circumstances, and a host of other external and internal forces that bore down on each community.

Because of the nature of the Appalachian landscape and because of the limited experience of a vast majority of homesteaders and communitarians, they quickly developed relationships with at least their immediate native neighbors and sought to recruit additional likeminded people to stave off social isolation. It was through these experiences that they built alternative sub-communities in the mountains and—simultaneously—began to make inroads into the local community.

The first several chapters analyze the forces that prompted young, white baby boomers to move to Appalachia and how natives and newcomers navigated different backgrounds and worldviews in their daily interactions. It pays close attention to how the media influenced perceptions of each group and how those perceptions shaped interactions in the earliest years of the movement. Chapter Two uncovers the many paths that led alter-natives into the mountains in the 1970s and early 80s, while Chapter Three describes the interactions and exchanges that occurred between natives and newcomers in the earliest years of the movement. Chapter Four explores at length the impulse for community and the development of countercultural subcommunities in Appalachia. These sub-communities served as the foundation of future grassroots initiatives, providing alter-natives with free spaces for the exchange of ideas and strategies as well as opportunities to cultivate social capital. They also helped to foster a sense of shared purpose and identity for the new arrivals. 
The remaining chapters examine the newcomers' involvement in various community initiatives and their responses to some of the challenges that came with living in rural Appalachia. Chapter Five examines environmental activism in Floyd and Lincoln counties. Specifically, it explores two environmental contests—a successful battle to keep surface mining out of the heart of Lincoln County and debates in Floyd over the fate of an ethanol plant that exposed differing visions of sustainability among alter-natives—-that illustrate the ways in which newcomers' activism could mobilize like-minded natives but could also ignite community divisions. These divisions were often expressed in outsider/insider distinctions, but they emerged from a variety of sources: locals' concerns about job creation and outmigration, community and social change, and elites jealous of their power.

Chapter Six expands on some of those themes by examining the myriad ways in which alter-natives participated in economic initiatives. It first explores underground economic activity, contending that activities like bartering and marijuana production sometimes united and sometimes divided natives and newcomers. It then examines agriculture and timbering, again showing how considerations of the region's agricultural heritage could either promote or limit community cohesion. And finally it considers economic revitalization in Floyd and Lincoln counties. Floyd County embraced tourism, an industry that can provide alternatives to resource extraction or supplement manufacturing but in reality does little to create the same levels of wealth as other economic sectors. Tourism proved to be divisive as well, as it resulted in gentrification and exposed divisions within the alternative sub-community, particularly among the "old-guard” and newer arrivals. In spite of alter-natives' and natives’ combined attempts to revive Lincoln's flagging economy, local politicians who continued to engage in corrupt practices and did little to encourage development resulted in renewed outmigration of many of 
the alter-natives as well as local youth. The study concludes with a brief description of contemporary developments in Floyd and Lincoln counties and explains why the former continued to develop since the 1980s, moving from a “distressed" to "transitional” status, while the latter continued to be one of the poorest in the region. 


\section{Chapter Two}

\section{From Inner City Chaos to "Mysterious Mountains”}

Joanie Goldsmith’s path to Appalachia began during the 1968 Democratic National Convention in Chicago. The experience of being beaten by police, with infant at her side, was enough to make her want to leave the city in which she had been raised. Shortly after the convention, radio personality and author Studs Terkel hosted agrarian advocate Mildred Jensen Loomis on his show. Goldsmith listened, captivated by Loomis's ideas about self-sufficiency and simple living. She had never before considered leaving the city, but Mayor Daley’s hostility toward activist youth and the resulting turmoil opened her mind to the possibility. "We were just so disillusioned by what happened in Chicago," Goldsmith recalls. "The police hated people with long hair ... it was very noticeable.” She and her husband Lawrence began their search for areas to which they could move. They wrote to the Heathcote Center, a rural education center and commune that Loomis had founded in Freeport, Maryland, and paid the place a visit. While they immediately felt at home there, they also explored other options, visiting friends in communes out west and a Quaker school in British Columbia, where they considered taking jobs as teachers. But Heathcote stuck with them, so they decided to move there in June of 1969. ${ }^{1}$

Heathcote, founded in 1965, was a new manifestation of a long-standing American critique of modernization, industrialization, capitalism, materialism, and the concentration of power and wealth in urban centers. The center was developed as part of the School of Living, a group founded in the 1930s by Ralph Borsodi who, through the institution, hoped to advance ideas about decentralization, which advocated providing people with the resources to be able to

\footnotetext{
${ }^{1}$ Joanie Goldsmith, interview by author, June 24, 2011.
} 
provide for themselves through land reform and small-scale farming. ${ }^{2}$ Borsodi's father William had been part of a circle of "single taxers," people who believed that all natural resources should be collectively rather than privately owned. ${ }^{3}$ At the School of Living's first community in Suffern, New York, residents owned their own buildings, while the School held the farmland in a land trust. Borsodi’s desire to see Americans return to agriculture was based on an old producerist vision of a society composed of “small-scale independent proprietors” that in popular memory harkens back to Jeffersonian agrarianism and the early president's belief in the virtue of independent yeoman farmers. ${ }^{4}$ Several of Jefferson's twentieth century successors, including both Roosevelts, and other progressive leaders and prominent social critics kept alive the Jeffersonian spirit. Their efforts to promote small-scale agriculture, country living, and selfsufficiency through both public and private programs typically arose in response to economic depressions and social unrest. It was not until the late $20^{\text {th }}$ century that environmental concerns joined the list of incentives for people to homestead. ${ }^{5}$

After World War II, national prosperity, stability created by welfare and other economic securities, and the oppressive political atmosphere suppressed the call to return to the land. Mildred Loomis was one of the few people who continued to promote homesteading from the

\footnotetext{
${ }^{2}$ Larry Lack, "Help Wanted at Heathcote Center,” Green Revolution, January 1976. Oddly enough, Dona Brown reveals that Borsodi initially supported New Deal subsistence homesteads that were controlled by the federal government until he became mired in a power struggle for federal funding at a Dayton, Ohio, community. The dispute between himself, Harold Ickes, and Milburn L. Wilson, director of the Subsistence Homesteads Division of the Department of the Interior, resulted in Borsodi's termination from his post. He henceforth included the federal government in his critique of centralized power, most notably in the 1947 reissue of his book Flight from the City. See Dona Brown, Back to the Land: The Enduring Dream of Self-Sufficiency in Modern America (Madison: University of Wisconsin Press, 2011), 169-170, 175.

${ }^{3}$ Brown, 167, 40.

${ }^{4}$ Brown, 174, 204; For more information on agrarianism throughout American history, see David Shi, The Simple Life: Plain Living and High Thinking in American Culture (Athens: University of Georgia Press, 1985). See also Daniel Walker Howe, What Hath God Wrought: The Transformation of America, 1815-1848 (New York: Oxford University Press, 2007), 44; Peter J. Schmitt, Back to Nature: The Arcadian Myth in Urban America (1969; repr., Baltimore: Johns Hopkins University Press, 1990); T.J. Jackson Lears, No Place of Grace: Antimodernism and the Transformation of American Culture: 1880-1920 (Chicago: University of Chicago Press, 1981).

${ }^{5}$ Brown, 147, 11.
} 
late 1940s through the early 1960s. Borsodi ultimately relinquished control of the New York School of Living community, but he and Loomis kept the concept alive by starting two new communities, one in Florida and another, which she managed, in Brookville, Ohio. But, as historian Dona Brown observes, "these were tiny enclaves, barely visible in politically inhospitable times.” The back-to-the-land vision virtually vanished from public consciousness during the 1950s, for economic prosperity and social welfare legislation had made Americans more secure than ever before. The political atmosphere was relatively hostile to radical utopian experiments such as communal living. Still, Loomis pressed on, perfecting the art of homesteading in Ohio and developing programs that would educate others on the art of selfsufficiency. ${ }^{6}$

By the early 1960s, Loomis found in civic-minded baby boomers a new audience for Borsodi’s ideas. In 1963 she founded an underground magazine called The Green Revolution that linked the decade’s activist spirit with back-to-the-land ideology. Using that and other media outlets, she tailored Borsodi’s message of self-sufficiency to younger audiences. In one letter written to The Green Revolution in 1970, she was somewhat critical of the counterculture's lack of cleanliness, but she generally welcomed "the gentleness, openness, sensitivity, and spontaneity of many young people..”7 That publication joined a growing body of literature, including the Whole Earth Catalog and Mother Earth News, that lent voice to the new back-tothe-land movement during the late 1960s and early 1970s. In 1965, Loomis opened yet another

\footnotetext{
${ }^{6}$ Brown, 204-205.

${ }^{7}$ Mildred J. Loomis, “Balance and Maturing,” Green Revolution, January 1970, 4.
} 
School of Living site, the Heathcote Center, which became "one of the first hippie communes" of the era. ${ }^{8}$

Loomis's efforts to promote Heathcote were extremely successful, and in some ways almost too successful for the commune’s permanent residents. "It was hopping," recalls Goldsmith. Because of its proximity to so many east coast cities, including Baltimore, Washington D.C., and Philadelphia, Heathcote proved to be a popular destination for people seeking refuge, community, and enlightenment. "All of the world's crazies and knowledgeables and eccentrics would pass through our doors and sleep on our living room floor," explains former Heathcote resident Tony Norris, "and Andrew Weil would drop acid in our cornfield. It was just such an incredibly fertile atmosphere." ${ }^{9}$ Another former resident, Paul Salstrom, who later edited The Green Revolution describes the scene as having been "a maelstrom where Reader's Digest-type housewives who were merely curious about organic gardening found themselves stumbling over bearded acidheads and being propositioned by self-proclaimed New Age gurus." ${ }^{10}$ According to Goldsmith, Heathcote hosted over two thousand visitors during the summer of 1969. Some people crowded into the dormitory, which had been built into a millhouse, while others camped out in retrofitted chicken coops and the carriage house. Goldsmith’s family and a few others, in order to maintain some form of privacy amidst the chaos, built small cabins on the property. That was not enough. Many of the permanent residents eventually found the Heathcote experience exhausting. The Goldsmiths were only there for a

\footnotetext{
${ }^{8}$ Brown, 204, 216; Timothy Miller, 60s Communes: Hippies and Beyond (Syracuse: Syracuse University Press, 1999), 8.

${ }^{9}$ Tony Norris, phone interview with author, May 19, 2011.

${ }^{10}$ Paul Salstrom, “The Neonatives: Back-to-the-Land in Appalachia's 1970's,” Appalachian Journal 30, no. 4 (Summer 2003): 318.
} 
year, and in a matter of two or three years, Joanie's entire cohort had left, many to settle on individual plots of land in Lincoln County, West Virginia. ${ }^{11}$

The Goldsmiths began homesteading in Lincoln County in May of 1970. While they were not the first alter-natives to settle there (one VISTA worker and several Catholic Workers who moved to the county in 1968 and 1969 earned that distinction), they were largely responsible for inciting a virtual flood of hip homesteaders to the county during the 1970s. Word of mouth, articles in popular homesteading journals, and a radio advertisement drew people to Lincoln County. But larger societal forces contributed as well, and by the late 1970s, the county's alternative population had swelled to between three and four hundred people. ${ }^{12}$ Other mountain communities became equally as popular. Towns like Elkins, West Virginia, hosted large populations of alternative in-migrants, as did the counties surrounding Boone, North Carolina, and Blacksburg, Virginia. One alter-native, when discussing his reason for moving to Floyd, Virginia, described the one-stoplight county as having been a "natural progression from Woodstock” because of its thriving countercultural community. ${ }^{13}$ People were drawn to Appalachia because of its rock-bottom land prices, scenery, proximity to urban centers, and preconceived notions about the local culture. The region seemed, on the surface anyway, to offer the sweetness of the southern climate, hospitality, and folk customs without the bitterness of the Deep South's racial intolerance. But perhaps more important, the region offered refuge from the likes of Mayor Daley, inner city turmoil, and later, economic and political upheavals that thrust the nation into a major identity crisis during the 1970s.

\footnotetext{
${ }^{11}$ By the start of 1976, Heathcote was in dire need of residents. See Larry Lack, "Help Wanted at Heathcote Center,” Green Revolution, January 1976, 4; Goldsmith interview; Salstrom, “The Neonatives,” 318.

${ }^{12}$ Salstrom, "The Neonatives,” 316, 318.

${ }^{13}$ Ed Gralla, interview by author, Floyd, Virginia, August 4, 2011.
} 
“It was loud and it was mean and it was violent”: Understanding the Migratory Push

Nineteen sixty-eight was a pivotal year for Joanie Goldsmith, as it was for the rest of America. The Tet Offensive, the assassinations of Martin Luther King, Jr. and Robert F. Kennedy, the Democratic National Convention in Chicago, and the election marked the beginning of the end of the postwar liberal consensus, that mid-century faith in a balanced economy regulated by a strong central government, social welfare legislation, and the communist threat to American prosperity. ${ }^{14}$ The election in particular, which brought Richard Nixon to power, spelled the end of the New Deal order, which had been a voting bloc composed of African Americans, intellectuals, poor southern whites, middle class urbanites, organized labor, and others who had swelled the ranks of the Democratic Party during Franklin Roosevelt's administration. Vietnam and the Democrats’ alignment with civil rights had crippled the coalition, while the New Left, disillusioned with liberalism’s lack of willingness to promote equality at all costs, “delivered the final blow.” By engaging in increasingly radical actions against the government and other bureaucratized institutions, young, white protesters drove a wedge between those African Americans and middle class whites who advocated for equality, on one hand, and lower and working-class whites who desired "law and order" and the maintenance of traditional values on the other hand. Although the Democrats enjoyed one final victory with the election of Jimmy Carter in 1976, Ronald Reagan’s assumption of the presidency in 1980 marked the end of the postwar liberal era. ${ }^{15}$

\footnotetext{
${ }^{14}$ Maurice Isserman and Michael Kazin, America Divided: The Civil War of the 1960s, $2^{\text {nd }}$ ed. (New York: Oxford University Press, 2004), 229-248; Ira Katznelson, "Was the Great Society a Lost Opportunity?” in The Rise and Fall of the New Deal Order, edited by Steve Fraser and Gary Gerstle (Princeton: Princeton University Press, 1989), 185205.

${ }^{15}$ Isserman and Kazin, 51, 244-248; Godfrey Hodgson, America in Our Time (Garden City, NY: Doubleday and Company, Inc., 1976), 67; Bruce Schulman, The Seventies: The Great Shift in American Culture, Society, and Politics (Cambridge, MA: DaCapo Press, 2001), 141.
} 
From 1968 until the early 1980s, ongoing social upheaval stemming from racial tension in urban areas blended with inflation, energy shortages, and growing concern about the environment to prompt over one million people to move to the countryside. Many of the back-tothe-landers and alter-natives moved because of a sense of fear and loss of control over their own destinies in the wake of events like the Chicago convention. Social commentators at the time and scholars since have often used the words "pessimism" and "malaise" to describe the tone of the 1970s. Back-to-the-land literature had pessimistic undertones_-former homesteader Eleanor Agnew calls it the homesteaders' "doomsday-leaning canon"—and it often conveyed a sense of urgency about staking claim on a plot of land as a protective measure against economic uncertainty, corporate bureaucracy, and what agrarian advocates believed was an increasingly untrustworthy and corrupt government. ${ }^{16}$ Stewart Brand’s 1970 warning was typical: “The time to get out of the city onto a plot of ground may be NOW. Even poor ground may be better than no ground at all." ${ }^{17}$ Paul Salstrom echoed the sense of urgency about finding land in 1972. "If and when America's market economy collapses," he wrote, "many of us will find ourselves refugees. If you'd rather not find yourself a refugee in that eventuality, the best preventative measure is to begin developing a self-sufficient homestead."18

Collectively, the issues that spurred the back-to-the-land movement cast a gloomy shadow over American society. Still, among many former New Leftists and counterculturalists, strains of 1960s idealism and optimism remained. The "Movement" - that collection of initiatives for social reform that began with civil rights and eventually championed the rights of women, homosexuals, and more—may have fractured, gas prices may have skyrocketed,

\footnotetext{
${ }^{16}$ Eleanor Agnew, Back From the Land: How Young Americans Went to Nature in the 1970s, and Why They Came Back (Chicago: Ivan R. Dee, 2004), 8.

${ }^{17}$ Stewart Brand, “Your Editor,” Whole Earth Catalog, Fall 1970, 23.

${ }^{18}$ Paul Salstrom, "Goats, Part 2," Green Revolution, May 1972, 6.
} 
inflation may have pinched purses, and two presidents may have fallen from grace in recent years, but homesteaders and communitarians believed that they still had the opportunity to forge a new world order, “an earth-shaking revolution” that could come "out of a potato patch."19 Michael Doyle, a professor cited in Eleanor Agnew’s Back From the Land, asserts, "We back-tothe-land people really conceived of ourselves as about to win. Our analysis of American society, we thought, was about to be proved accurate.” Alternative agrarian communities, he continued, "would serve as laboratories of the next civilization that would supplant the existing discredited American civilization.”20

Even in 1970, a year defined by violent protests, the newly created Mother Earth News was able to issue a cheery report on a commune, Twin Oaks, that had been founded in 1966 just east of the Shenandoah Valley in Virginia. "Twin Oaks people see themselves as only the beginning of what they expect will become a very large movement—a movement of young people forming groups so alternate social structures may be experimented with to find the structures that produce the things that people value.” The idea was to mix partial self-sufficiency with meaningful productive work (in the form of a hammock business), embrace technology, and "reform" their residents to become accustomed to communal living so that new generations of people could "throw off their previous conditioning by straight society."21 Even in a place like Appalachia, with its history of exploitation and poverty, remarked Salstrom, the fact that "newcomers" in Lincoln County "have met with a deep acceptance ... may portend a new and brighter era for the region.,22

\footnotetext{
${ }^{19}$ Ken Kern, "By the People, For the People, and of the Earth," Green Revolution, February 1975, 3.

${ }^{20}$ Agnew, 7.

${ }^{21}$ Editors, “Twin Oaks: The Great Farm Revolution,” Mother Earth News, January 1, 1970: under "Twin Oaks,” http://www.motherearthnews.com/Nature-Community/1970-01-01/Community-Approach-To-Revolution.aspx (accessed December 17, 2011).

${ }^{22}$ Paul Salstrom, “Report from W. Virginia,” Green Revolution, February 1975, 1,7.
} 
As with all social movements (and the back-to-the-land movement was comparatively small when measured against the era's other mass movements), ${ }^{23}$ there were complicated and long-standing trends that fed it and gave it shape. Immediate concerns of the day certainly spurred the back-to-the-land movement, but it had also been born of (or revived by, depending on the viewpoint) cultural and political developments that extended several decades back to the depression and immediate postwar era. The optimistic strain in homesteading rhetoric derived in part from postwar liberalism, the political ideology of reform that was “forward-thinking” but maintained a fervent belief in the government's ability to improve society. Some liberals were relatively utopian (such as New Dealer and back-to-the-land enthusiast Arthur Morgan), while others remained grounded in reason. As New Left veteran Todd Gitlin observes, all generally felt that "society could be understood and, once understood, rationally steered through responsible action.”24 This mid-century liberalism was markedly different than the liberalism of the early New Deal, which still embodied a class-based analysis of society. The 1937 recession and, later, the wartime experience transformed the philosophy into one that emphasized the "rights and freedoms of individuals and social groups” over the importance of economic equality. ${ }^{25}$

\footnotetext{
${ }^{23}$ Jeffrey Jacob, New Pioneers: The Back-to-the-Land Movement and the Search for a Sustainable Future (University Park: Pennsylvania State University Press, 1997), 4-5.

${ }^{24}$ Todd Gitlin, The Sixties: Years of Hope, Days of Rage (New York: Bantam Books, 1987), 58.

${ }^{25}$ Alan Brinkley, The End of Reform: New Deal Liberalism in Recession and Reform (New York: Vintage Books, 1995), 8-11, 164-168. Alan Brinkley elucidates this process in The End of Reform. He roots the shift from laissezfaire liberalism to rights-based liberalism in the 1930s and World War II. Although New Dealers had rejected progressives' concerns with reforming political and business corruption, they embraced the notion that the government should oversee the economy. While the 1937 recession, which left many New Dealers doubting the government's ability to restore economic prosperity, quelled support for a massive economic overhaul, it perpetuated the idea that "liberalism meant a commitment to reform, and in particular to using government to deal in some way with the problems of the modern economy.” Reform impulses remained to an extent through World War II, but the rhetoric focused increasingly on sustaining economic growth rather than restructuring the economy. Wartime economic recovery and consumer spending prompted a renewed faith in capitalism, and the federal government's mobilization and war contracts legitimized Keynesian fiscal policies. This sparked a renewed belief in capitalism's ability to spur continual economic growth and to raise everyone to a higher standard of living. Wartime critiques of totalitarianism and fascism abroad hastened the shift by illuminating the issue of equal rights at home. African American soldiers were particularly influential in this development; they pointed out that America, which was supposed to stand for freedom, was oftentimes less accommodating to blacks and other minorities than some of the countries in which they were fighting. After the war, they increased their calls for government legislation to
} 
The liberals who shaped mid-century politics (and gave birth to sons and daughters who later rebelled against their policies during the 1960s) believed in the power of the federal government to champion the rights of the average person. They also believed that the "government was the natural ally of the common people at home and the natural enemy of totalitarianism abroad." ${ }^{26}$ They embraced the welfare state, Keynesian fiscal policies, and the idea of social equality. But they were not always politically strong enough to push through legislation that could enact major social or economic reforms. ${ }^{27}$ Quite often, liberals found themselves having to back away from civil rights issues to maintain support from southern Democrats. To be sure, social welfare legislation that had been implemented during the New Deal-era remained in place, but anticommunism and a conservative political atmosphere dominated the political landscape from the late 1940s until the early fifties. ${ }^{28}$ During the 1950s, racial tension, anticommunism, and organized labor that had been weakened by Taft-Hartley and McCarthyism divided the Democratic Party. In an effort to regroup, liberals continued to reach out to southern Democrats. To do this they maintained a moderate political stance, which left little to distinguish the Democrats from Republicans. With Stalin’s passing and the end of the Korean War in 1953, and McCarthy's censure the following year, a liberal consensus had been born. $^{29}$

address inequality and racism. The black migration to northern urban centers, coupled with the "labor-capital accord" that occurred during World War II, further pushed the political dialog toward race relations and away from economic restructuring.

${ }^{26}$ Gitlin, 58.

${ }^{27}$ Isserman and Kazin, 48.

${ }^{28}$ President Truman's Fair Deal expanded New Deal programs but did little to challenge capitalism. The Fair Deal reflected the new rights-based liberalism to some degree in that it desegregated the military, increased the minimum wage, expanded Social Security, and passed the Housing Act, but congressional conservatives weakened organized labor through the Taft-Hartley Act, prevented more advanced civil rights legislation, curbed aid to education, and prevented the passage of national health insurance. Alonzo Hamby, "The Vital Center, the Fair Deal, and the Quest for a Liberal Political Economy,” The American Historical Review 77, no. 3 (June 1972): 653-678.

${ }^{29}$ Hodgson, 67. 
With the adoption of consensus little partisan conflict occurred in the years immediately following the 1952 election. President Eisenhower enjoyed a GOP-controlled Congress in his first term, and until his appointment of Justice Earl Warren in 1953, he enacted a fairly conservative agenda. He remained unresponsive to civil rights issues throughout his administration, believing correctly that adopting a pro-civil rights stance or addressing the issue of poverty would alienate the Dixiecrats. But Eisenhower, acutely aware of the popularity of certain New Deal programs, expanded some social programs including Social Security. ${ }^{30}$ The federal government's failure to address economic and social inequality frustrated not just African Americans and young white activists in the 1960s; it also fed into growing resentments of the working class and other groups that eventually turned away from the New Deal order as society unraveled during the late 1960s.

The inability of New Dealers and postwar politicians to enact major economic reforms and to address inequality aside, the postwar era experienced unprecedented economic growth and stability. Children born into this prosperity enjoyed a period of exceptional national wealth and confidence, and this played a major role in shaping their outlook toward society. Between the end of World War II and the early 1970s, America was riding a wave of economic growth spurred by war-torn foreign markets, government defense spending, full employment, relative political stability, and increased consumer spending. Both working class and middle class Americans enjoyed varying levels of discretionary income. The baby boom, which saw four million babies being born per year during the 1950s, helped fuel the economic engine. People wanted to exercise their new purchasing power, and they needed more space in which to put their growing families and consumer goods. Spurred by the federal GI Bill, suburban developments

${ }^{30}$ Gary W. Reichard, Politics as Usual: The Age of Truman and Eisenhower (Wheeling, IL: Harlan Davidson, Inc., 1988), 126; Carl M. Brauer, “Kennedy, Johnson, and the War on Poverty,” Journal of American History 69, no. 1 (June 1982): 101. 
sprang up on city outskirts. Between the late 1940s and the 1950s, nearly eighty-five percent of all new homes built were suburban. ${ }^{31}$ Children raised amidst these developments enjoyed various forms of entertainment: televisions, toys, popular music and literature, drive-in movie theaters, and family vacations. This prosperity led many to believe that poverty and hardship were becoming things of the past. Even though economic inequality still existed, many in the lower classes had risen to a more comfortable economic level. ${ }^{32}$

The relative affluence of the era imbued baby boomers with a sense of self-confidence and optimism that they carried with them into their adulthood. James Patterson calls the 1950s and sixties an era of "grand expectations," when scientific developments, prosperity, and the belief in the ability of the federal government to solve the nation's social problems fostered an “optimistic spirit” that would later turn rights-based liberalism into a rights revolution. Experts, people believed, had an answer for everything, from eradicating polio to sending humans into space. Government officials spoke confidently about eradicating poverty and hunger and equalizing people regardless of class, ethnicity, or religion. And the sheer numbers of baby boomers gave that generation a sense that they, too, could accomplish anything. With their access to knowledge through higher education, they believed that they had the ability to usher in a new era of freedom and prosperity that had never before been experienced. ${ }^{33}$

John F. Kennedy symbolized this postwar optimism, although scholars contend that this perception was based more on JFK's style than on substance. Allen Matusow asserts that people's confidence in Kennedy upon his election rested more on his potential for greatness than

\footnotetext{
31 James T. Patterson, Grand Expectations: The United States, 1945-1974 (New York: Oxford University Press, 1996), 333.

${ }^{32}$ Gitlin, 12-13; Isserman and Kazin, 12; Patterson, 313-317.

${ }^{33}$ Patterson, 317, 451-452; Berkowitz, 6; Gitlin, 18.
} 
on past actions that had demonstrated greatness. ${ }^{34}$ Still, JFK’s youthful swagger and good looks seemed to embody a revived liberalism in the sixties, one that provided a renewed focus on social justice and other causes. ${ }^{35}$ His election ushered in a new era of tolerance that enabled civil rights leaders to be more assertive about their demands for equality. And international criticism about ongoing American racism stung Kennedy and other liberals in the context of the cold war. By 1963, Kennedy bowed to both international and domestic pressure to respond to southern violence and delivered a speech calling for new civil rights legislation. ${ }^{36} \mathrm{He}$ also, somewhat reluctantly, attended to the liberal issues of women's rights and poverty, the latter of which brought renewed attention to Appalachia. ${ }^{37}$

But there were dark undertones to the 1950s and early sixties that reached deep into the psyches of many baby boomers, undertones that eventually led them to question conventional notions about prosperity, the good life, and the benevolent authority of an increasingly powerful centralized government and its "experts." Beginning in the late 1950s, intellectuals, politicians, and social critics such as Michael Harrington began writing about America’s hidden pockets of poverty. The discovery of indigence in inner cities and rural areas, notes historian Ronald Eller, "challenged the optimistic assumptions that underlay the affluent society—-the premise that the American path to affluence would eventually produce a unified, classless, and rich society.” ${ }^{38}$ In some ways, Appalachia became the postwar poster child for populations left behind. In the coalfields, mechanization of the coal industry and declining demands for the black rock had left thousands of people unemployed and destitute. Between 1940 and 1960, nearly 1.2 million

\footnotetext{
${ }^{34}$ Matusow, 13-14.

${ }^{35}$ Isserman and Kazin, 57. Isserman and Kazin describe JFK, however, as a pragmatic politician who dismissed "idealists and moralists as sentimental fools."

${ }^{36}$ Mary L. Dudziak, Cold War, Civil Rights: Race and the Image of American Democracy (Princeton: Princeton University Press, 2000), 154-155, 179, 201.

${ }^{37}$ Isserman and Kazin, 65.

${ }^{38}$ Ronald D. Eller, Uneven Ground: Appalachia Since 1945 (Lexington: University Press of Kentucky, 2008), 2, 92.
} 
people responded to persistent unemployment by leaving eastern Kentucky and West Virginia in search of jobs elsewhere. Non-coal producing areas similarly suffered. Agricultural production had been declining in the region since the early 1900s, and industrialization hastened the process: "Between 1950 and 1960, half of the farmers and farm laborers in Appalachia left the land. By the end of the decade, only about 6 percent of the mountain population was employed full time in agriculture.” Even the region’s urban centers suffered. Many who remained in the mountains became impoverished, struggling through periods of unemployment and becoming increasingly reliant on welfare for survival. ${ }^{39}$

The notion of persistent poverty in Appalachia entered baby boomers' consciousness through a barrage of television images, books, and articles. In 1960, Kennedy visited southern West Virginia in an effort to rally support for his campaign. As a Catholic, he was initially concerned with overcoming religious barriers in a traditionally Protestant state, but while he was there scenes of poverty and desperation moved him. Cameras following the young candidate captured images of unemployed coal miners and soiled children with tattered clothes. A media frenzy ensued. Journalists from the New York Times and Washington Post, television anchors, and other writers from popular magazines delivered to the masses images of financial hardship and pain. And in 1963, Harry Caudill published Night Comes to the Cumberlands, his widelyread chronicle of Appalachian poverty that placed the blame for Appalachian indigence not solely on attributes or cultural isolation, as had earlier critics, but on absentee industrialists and corrupt politicians who had systematically exploited the region's natural and human resources. These accounts helped to build political support for federal programs that could develop the region. But it also solidified the image of Appalachia as a place in, but not of, America; a place

\footnotetext{
${ }^{39}$ Eller, 2, 28-29.
} 
of outsiders. ${ }^{40}$ And it stained the perception of American economic strength, a fact that greatly troubled cold warriors like Kennedy. ${ }^{41}$

Other problems cast shadows over the affluent society in the 1950s and early 1960s. Todd Gitlin describes the 1950s as "a seedbed as well as a cemetery,” referring to both the hope for the future that came out of prosperity and pervasive fears rooted in past and current circumstances. At a time when America was celebrating nearly full employment and unprecedented economic growth, some still questioned whether consumer goods provided the ticket to personal fulfillment. Baby boomers may have enjoyed relative comfort, but they were constantly being reminded that prosperity could be fleeting. Living with the memory of the Great Depression, adults, says Gitlin, "were acutely aware of how hard they had worked to afford the picture window, the lawn, the car, the Lionel trains." There were lingering doubts "that their well-upholstered consumer paradise was here to stay.” (According to regional scholar Jerry Williamson, the era's popular hillbilly cartoons and movies such as Ma and Pa Kettle didn't do much to help middle-class adults forget. On one hand, the hillbilly served as a form of comic relief, reminding middle-class Americans that there was always somebody lower on the economic totem pole. On the other hand, it also reminded them that they were one financial disaster away from becoming hillbillies themselves. This American icon, he warns, "is a keep away sign on the far edge of our own deniable possibilities”). ${ }^{42}$

Expendable income couldn't ease fears of economic hardship, nor could it ameliorate the anxiety that came from the cold war. A couple of back-to-the-landers rooted their decision to homestead not in the context of the late 1960s or 1970s, but in their childhoods. "You have to

\footnotetext{
${ }^{40}$ Eller, 53-54, 61-67, 136.

${ }^{41}$ Brauer, 101.

42 Jerry Williamson, Hillbillyland: What the Movies Did to the Mountains and What the Mountains Did to the Movies (Chapel Hill: University of North Carolina Press, 1995), 5.
} 
use your head to project here," advised West Virginia back-to-the-lander Bill Ambrose. “This whole time that we were growing up, there was this specter of utter annihilation. And the missile gap, which never existed by the way, the idea that we were always behind the Soviets, it was always this. I mean I remember! I really bought into it.”43 Judy Hile’s fears of Russians and a nuclear attack were so pervasive, she was still afraid after she began to homestead in West Virginia:

I was ten when my little brother was born, and my biggest focus of concern about my baby brother-I used to lay awake at night—was that when the Russians came to our front door ... in Orlando, where was I going to hide him. And I finally kind of settled on, it would be a dresser drawer. I'd put him in my dresser drawer. And when we first started homesteading in West Virginia and I had my first baby, I was trying to think when the big nuclear incident happened, we would go in our cellar house where there were potato bins and things. But that wouldn't help for very long ‘cause we'd need some air at some point. ${ }^{44}$

Communism, nuclear annihilation, juvenile delinquency, UFOs...there was no shortage of real (and imagined) monsters lurking under baby boomers' beds. The era’s anxiety manifested itself in several ways, from the escalating numbers of life insurance policies being taken out to the explosion of psychiatry practices opening between 1940 and the mid-sixties. ${ }^{45}$

There was yet another mid-century concern that shaped baby boomers and later influenced some people's decisions to embrace the simple life: the loss of individuality and

\footnotetext{
${ }^{43}$ Bill Ambrose, interview by author, Wood County, West Virginia, January 27, 2011.

44 Jane Hearne, interview by author, Wood County, West Virginia, January 27, 2011.

${ }^{45}$ Gitlin, 12, 17-26.
} 
autonomy at the hands of mass culture. ${ }^{46}$ Reflecting the larger shift in focus away from classbased analyses and the oppressive political atmosphere of the late 1940s and 50s, former Marxist intellectuals were no longer able to target America's political economy as the root cause of society's problems for fear of being persecuted as communist sympathizers. Instead, they increasingly took issue with "mass culture," referring to the creation of expressive forms for consumption by vast audiences rather than creation that stemmed from purely artistic impulses. ${ }^{47}$ A number of bestselling books were released during the 1950s that questioned mass culture's role on the loss of the middle-class's entrepreneurial spirit, creativity, and autonomy. America's growing middle-class, charged thinkers like C. Wright Mills, was in danger of becoming the pawns of corporate businessmen, bureaucrats, and military leaders. ${ }^{48}$ Mass culture, they feared, was choking individual expression in America.

Mass culture created the problem of an unthinking, homogenized middle-class, yet it also provided a solution. Because the intellectuals' criticism was typically targeted at people in the center of the economic spectrum, Americans began to see people existing on the margins of society as a potential answer. Historian Grace Elizabeth Hale details this phenomenon in A Nation of Outsiders. Rebellious fictional characters portrayed by James Dean, as well as real life African Americans, Native Americans, and other marginalized people, all became the subjects of white middle-class fantasies through records, radio, literature, films, and television. The postwar middle-class youth's romanticization of people on the fringe of society began with black culture that they absorbed through early white rock-and-roll stars like Elvis who emulated black performers. Corporations capitalized on the outsider frenzy. "To keep the mainstream

\footnotetext{
${ }^{46}$ Ibid., 17-26.

${ }^{47}$ Grace Elizabeth Hale, A Nation of Outsiders: How the White Middle Class Fell in Love with Rebellion in Postwar America (New York: Oxford University Press, 2011), 36.

${ }^{48}$ Gitlin, 19.
} 
entertained,” says Gitlin, they “scouted the margins, absorbing outsiders and outsidedness, packaging them in marketable form, relaying the idea that authorities were questionable and that to be young was to be weird, angry, marginal, dispossessed." ${ }^{49}$ The imagined connection deepened during the folk revival of the late 1950s and 1960s. This allowed fans to experience raw and emotive sounds from America's tucked away places. In the voices of performers like southern bluesman Mississippi John Hurt and Appalachian songbird Jean Ritchie, young people could imagine themselves away from the sterile, homogenous confines of the suburbs and as part of a more authentic, feeling, autonomous culture. "Folk music," explains Hale, provided a refreshing break from the "fake, plastic, slick, mass-produced, usually segregated" mainstream. ${ }^{50}$ This imagined connection to marginalized groups matured during the 1960s as young white college students labored alongside civil rights workers in the South and, later, the urban poor and destitute Appalachians. To express solidarity with America’s outsiders, they began remaking themselves as part of the folk in their dress, speech, and choices of where and how to live. ${ }^{51}$ They joined them in order to resolve "an intractable mid-century cultural and political conflict, the contradiction between the desire for self-determination and autonomy and the desire for a grounded, morally and emotionally meaningful life." ${ }^{52}$

Activist baby boomers based their solidarity with African Americans and other marginalized groups on an imagined sense of shared alienation from Middle America and its culture of conformity rather than on shared class or political ideologies, as had previous generations of radicals. Because of the cultural criticisms popularized by C. Wright Mills, Albert Camus, and other intellectuals in the late 1950s, the emerging New Left became concerned with

\footnotetext{
${ }^{49}$ Gitlin, 29.

${ }^{50}$ Ibid., 84.

${ }^{51}$ Ibid., 84, 106.

${ }^{52}$ Ibid., 3.
} 
declaring not just political or economic freedom, but psychological freedom as well. "The Port Huron Statement," says Hale, "positioned white college students as outsiders with a crucial role to play in a New Left political alliance. And it accomplished this essential revision of the Old Left's vision of a coalition grounded in economic exploitation by expanding the definition of oppression to include psychological and cultural alienation.”53 James Patterson's research supports Hale’s interpretation. "Millions of Americans,” he asserts, “imagined, often narcissistically, that they could achieve great personal 'growth' and 'self-actualization.”' Rightsbased liberalism expanded to encompass not only equal access to economic, social, and political institutions; it began to include the right to "profound psychological satisfaction." 54

White baby boomers' search for psychological well-being was rooted in postwar affluence—people had to "come from comfortable backgrounds" in order to "reject middle-class comforts," notes Timothy Miller—and it first manifested itself through their work with the civil rights movement. ${ }^{55}$ But in response to African Americans' rejection of white involvement in their liberation efforts during the mid-to-late 1960s, the latter turned to other marginalized groups and entities to find meaning and purpose. Some activists turned back to Old Left principles to advocate on behalf of the working class. Paul Gallimore, who eventually moved to an intentional community in western North Carolina, taught math and science classes to inner city children in Alexandria, Virginia. He described the experience as helpful to them but also "nourishing” to him: "I’m getting a sense of participating in something greater than myself, and being a part of the healing and not so much the hurting." ${ }^{56}$ Others, including the VISTAs and

\footnotetext{
${ }^{53}$ Ibid., 179.

${ }^{54}$ Patterson, 452-453. Patterson doesn't limit the pursuit of rights to baby boomers; Civil Rights workers, union members, Native and Hispanic Americans, the elderly, the poor, and a variety of other "public interest groups" began to demand certain protections under the law.

${ }_{55}^{5}$ Miller, 15.

${ }^{56}$ Paul Gallimore, interview by author, Leicester, North Carolina, June 12, 2008.
} 
Appalachian Volunteers, switched their focus to impoverished Appalachians ${ }^{57}$ Some organized for women's, GLBT, and Native American liberation, and some advocated for a non-human entity: the environment. Then there were the hippies who simply turned inward, seeking to find transcendence in their own minds and bodies. Using psychedelics, sex, nature, and an amalgamation of eastern, Native American, and self-created spirituality, the counterculture launched its search for greater purpose in life within the inner recesses of the mind. ${ }^{58}$

In the 1970s, as hippies and New Leftists matured, a general trend emerged among their cohort of emphasizing simplicity over conventional middle-class displays of wealth in order to achieve emotional grounding. The foundational beliefs behind the push for simplicity, observes David Shi, "included spiritual commitment, civic involvement, human-scale technology and decision-making, ecological awareness, and conscientious consumption." ${ }^{59}$ For many, the pursuit of psychological satisfaction that came from living an ecologically and socially responsible existence meant fully engaging in a self-sufficient lifestyle in the country. ${ }^{60}$ The solution to pollution, overpopulation, and overconsumption, wrote an anonymous contributor to the Last Whole Earth Catalog, was finding "psychological techniques for creating an awareness of 'self' which includes the social and natural environment." "61 "We yearned for psychic rewards and spiritual wealth" instead of money, recalls Eleanor Agnew, "so we planned to generate mere

\footnotetext{
${ }^{57}$ As an example, Hale refers to the Whitesburg, Kentucky, media production company Appalshop, which was founded as a War on Poverty project. But she fails to add that the program actually helped to keep a small group of young natives from leaving the region by providing them with employment opportunities and a new lens, so to speak, through which they could analyze and understand their own communities. Ibid., 227.

${ }^{58}$ Ibid., 226-229.

${ }^{59}$ Shi, 268-269.

${ }^{60}$ Jeffrey Jacob's survey demonstrates that those living full-time in the country actually do achieve a high-level of psychological satisfaction from the experience in spite of the problems inherent in living in rural areas; ninety-three percent reported being "very or fairly satisfied" with where they live. Jacob, 100-103.

61 "Four Changes,” The Last Whole Earth Catalog, June 1975, 45.
} 
trickles of cash flow from our cottage industries, manual labors, and crops. The payoff was to be freedom.,

The search for psychological grounding and self-determination that led some baby boomers to embrace voluntary simplicity also had the unanticipated and unfortunate effect of destroying the New Left's vision for building a broad progressive movement. The problem with white romanticization of marginalized groups was that it veiled important differences between themselves (middle-class youth) and the nation's economic outsiders. They were unable to recognize, and deal with, important class, race, and gender differences that existed between themselves and the people they idealized. African Americans wanted equality with whites, not to be the catalyst for young whites' quest for authenticity, meaning, and fulfillment. Black leaders understood that economic privilege was what enabled young, middle-class Americans to remake their lives in the image of the poor. Leaders such as Stokely Carmichael began to advise whites to advocate on behalf of their own people and encouraged blacks to do the same. Of course, this separatist rhetoric also stemmed from the continuing racism of white America in general and the failure of postwar liberalism “to represent all American citizens."63 "Racial separatism,” writes Allen Matusow, “found expression at mid-decade both in the slogan 'black power' and, more ambiguously, in the great ghetto riots” that crippled cities during the second half of the decade. ${ }^{64}$ In an indirect way, then, baby boomers' search for authenticity helped to launch the back-to-theland movement on two fronts: internally, within their own minds, and externally, as African Americans' dissatisfaction with ongoing racism and inequality was expressed through a wave of inner city riots.

\footnotetext{
${ }^{62}$ Agnew, 4.

${ }^{63}$ Hale, 204-208, 235-236.

${ }^{64}$ Matusow, 345.
} 
A critique of cities is almost ubiquitous in twentieth century back-to-the-land literature. Generations of agrarian advocates have railed against urban areas because of their high crime rates, the materialist cultures that they represent, the pollution that they create, and the dangerous and/or mind-numbing work that they demand of their residents. "How could we enjoy" the luxury of cities, asked Ralph Borsodi in 1933,

when we were financially insecure and never knew when we might be without a job; when we lacked the zest of living which comes from real health and suffered all the minor and sometimes major ailments which come from too much excitement, too much artificial food, too much sedentary work, and too much of the smoke and noise and dust of the city ... when our lives were barren of real beauty - the only beauty which comes only from contact with nature and from the growth of the soil, from flowers and fruits, from gardens and trees, from birds and animals? ${ }^{65}$

The 1970s were no different. The counterculture viewed cities as centers of power and corruption, while the rest of America began to associate them with high crime rates, racial violence, and pollution. In 1975, Robert Rodale observed that the long-standing trend of migration to cities was reversing. The thousands of people leaving urban areas wanted to "put some distance between” themselves “and the mob,” and “generate self-sufficiency.”66

Crime and racial tension were significant motivators for would-be homesteaders and alter-natives to leave. Although the majority of media attention during the early 1960s had been paid to racial violence in the South, by the end of the decade Detroit, Los Angeles, and other urban areas had experienced their own wave of civil rights-related turmoil. Tension had been

\footnotetext{
${ }^{65}$ Ralph Borsodi, Flight from the City: An Experiment in Creative Living on the Land (1933; repr., New York: Harper Colophon Books, 1972), 2-3.

${ }^{66}$ Robert Rodale, "Rural Renaissance on the Way,” Organic Gardening and Farming, September 1975, 44.
} 
simmering for years because of the influx of southern African Americans to the rust belt of northern cities. Middle and working-class whites, many from immigrant backgrounds, had typically responded to the demographic change by moving to the suburbs. But buying new homes became more difficult in the inflationary 1970s. Blue-collar workers harbored lingering resentment toward blacks for affirmative action, a practice that they feared might cost them jobs in an unfavorable economy. And the issue of busing, a solution imposed on many school districts that still supported largely segregated neighborhood schools, became incredibly divisive. In areas like Boston, neighborhood schools came under fire for having failed to meet the demands of Brown v. Board of Education, so a federal judge implemented busing as the solution. Such measures increased resentment that whites felt toward African Americans who they believed had received special privileges as a result of the Civil Rights Act of 1964 and subsequent legislation. ${ }^{67}$

Inner city crime was a common complaint among homesteaders. "It was a combination of noise, pollution, and crime in the city which caused us to take that drive through the country in 1969,” recalled Paul Edwards, who later moved to Guernsey County in Appalachian Ohio. ${ }^{68}$ West Virginia alter-native Connie Abraham, who had actually grown up on a Michigan farm, quickly realized after graduating college that she could not tolerate living in an urban area.

After graduating I moved to a Detroit suburb and taught first grade there for six years, and it was that period of time when the Vietnam war was going on, there were race riots in the streets, and the cities were burning, and Attica prison was going on. I mean, there was so much going on at that time, it just seemed to be overwhelming. It was loud and it

\footnotetext{
${ }^{67}$ Berkowitz, 173-176.

${ }^{68}$ Paul Edwards, “Report from Them That's Doin'," Mother Earth News, March / April 1976”: under "Paul Edwards," http://www.motherearthnews.com/modern-homesteading/becoming-self-sufficient-zmaz76mazhar.aspx (accessed December 19, 2011).
} 
was mean and it was violent and I needed to get away from that. And that's one of the reasons why I came. I knew I didn’t want to go back to my hometown, and I knew I didn’t want to stay in an urban area. I knew that. It just didn’t fit me to be in an urban area. $^{69}$

Karl Hess, who had at one time written speeches for Barry Goldwater and other Republican politicians, moved to Berkeley County, West Virginia, in the mid-seventies after having been the victim of several robberies in the Adams-Morgan area of Washington D.C. Hess had already become a harsh critic of the military-industrial complex that he had once celebrated, and he had engaged in several urban agricultural and aquacultural endeavors while in D.C. But "crime ... caused us to leave Adams-Morgan,” he confided to Mother Earth News's “Plowboy." "We were robbed about once every two months during the years we lived there.”70

Several of the earliest "new pioneers" can pinpoint a specific moment at the end of the 1960s that prompted them to consider escaping the violence and hostility rankling urban areas. For many, painful experiences at decade’s end were their major push factors. Marjie Shew, who was in college in Baltimore during the mid-sixties, joked that she "majored in nonviolent protest.” But she eventually grew tired of being arrested at rallies, and after teaching for a time in an area of Washington D.C. that had been subject to rioting after Martin Luther King's death, she realized that she "needed to either move deeper into the city and live in the problems or get out

\footnotetext{
${ }^{69}$ Abraham interview.

${ }^{70}$ Karl Hess, "Presidential Speechwriter Turned Homesteader,” Mother Earth News, January 1, 1970: under "Karl Hess,” http://www.motherearthnews.com/Nature-Community/1976-01-01/The-Plowboy-Interview-Karl-Hess.aspx (accessed December 20, 2011).
} 
and live an alternative lifestyle.”71 Jayn Avery, who moved to Floyd, Virginia, in the early 70s, had participated in the student movement and lived in Berkeley at the height of what she calls “absolute hippiedom.” But she shed her hip connection after attending the ill-fated Altamont Music Festival in 1969. She recalls:

That, to me, was the opposite of Woodstock. It was the closing of the gate ... I walked out of that, just before, thanks to David Crosby I think it was, or one of those guys who said, "If you have it together at all, leave now" in the middle of the concert. And Grace Slick and all those guys were doing their thing and saying, "This is not right. Something’s not happening.”

Avery left the festival just prior to Meredith Hunter's stabbing and considers that moment of departure as her "conscious shift to the back-to-the-land movement."72

Jim Chojnacki witnessed the Kent State shootings, and that event sparked his decision to move back-to-the-land. "College took me out of society,” he recalls. "Kent being the place it was, got a big dose of political action and police action, National Guard action. It was a bitch of a time to be in college.” When asked to reflect on the day, he said:

I was standing behind Jeff Miller from here to about maybe the store. He got it in the head. I was standing there, thunder going off, thinking, 'Blanks,' and a bullet hit a sign next to me from here to the tree. It rang out. So I was like, 'Oh, not blanks.' Hit the ground. And it got quiet and I got up and exited down the hill to the left. Wasn't about to take another volley. I missed a lot of the mopping up action. Ended up back in the suburbs. That night they closed down the school, kicked everybody out. Got the few days

\footnotetext{
${ }^{71}$ Marjie Shew, unpublished essay delivered via email message to author, July 1, 2009.

${ }^{72}$ Jayn Avery, interview by author, Floyd, Virginia, July 23, 2008.
} 
of realizing that most people didn’t think they killed enough. There was the big vocal applause in support of the killings. Kind of set me a little further distance from my fellow citizens. $^{73}$

While Chojnacki was the only person interviewed for this project who personally witnessed the shootings, another alter-native cited that event as being a major impetus to escape mainstream America. Although Kip Rondy did not move to West Virginia until 1974, Kent State, Martin Luther King's assassination, and other troublesome events of the late 1960s left him with the "sense that things were really unraveling fast." Some of his friends at Kent eventually told him about land in Lincoln County. And after being repeatedly harassed by the police throughout the early seventies, he decided to pay the county a visit. ${ }^{74}$

Reflecting the difficulty of the time, most alter-natives cite Vietnam or general feelings of uneasiness and disillusionment about the era. Many developed a lack of desire to keep supporting with one's time, talent, or finances the bureaucratic machine of which they feared they had become a part during their college years, war service, or employment. Cindy Rank, a native Pittsburger who settled in West Virginia, rooted her decision to move in "an underlying uneasiness with the world and where it was going. ${ }^{, 75}$ Patricia Harman, who first homesteaded in Minnesota and later moved to West Virginia, reflected on her husband's decision to dodge the draft and his effort to "create a new world" by protesting the war and moving back-to-the-land. His decision hurt his family, who at the time supported the war, and he feared that they viewed him as "crazy, or worse, un-American.” Harman summarizes the era by considering underlying current of pain running through the events of the time:

\footnotetext{
${ }^{73}$ Jim Chojnacki, interview by author, Lincoln County, West Virginia, July 2, 2011.

${ }^{74}$ Kip Rondy, interview by author, Athens, Ohio, March 24, 2011.

${ }^{75}$ Cindy Rank, interview by author, Morgantown, West Virginia, July 31, 2008.
} 
TV and movies portray hippies and protestors as kids going crazy with love and drugs, but in reality there was pain everywhere. Pain, on our families' parts, when they lost their children to a world they didn’t understand. And pain, on our part, when our parents rejected us for not believing what they believed and not wanting to live as they lived.

Pain when we saw the photos of the war on TV. Pain when people we loved were put in jail for protesting or killed as soldiers in the jungles of Vietnam. We put flowers in our hair, partly to celebrate and partly because we'd be too sad if we didn't. ${ }^{76}$

The pain that Harman describes fed into the disillusionment and pessimism that defined the 1970s and spurred the back-to-the-land movement. ${ }^{77}$ That strain of liberal optimism never completely disappeared, but the emphasis on public activism faded somewhat as part of a larger trend toward privatization. As the Movement fractured and split into interest groups, "The personal and rooted,” recalls Todd Gitlin, became “more appealing than the political and outré. ${ }^{78}$ The trend extended top to bottom. Politically, Nixon began the process of shifting power away from the federal government and toward state, local, and corporate institutions that Reagan would complete in the 1980s. Reflecting this trend, Americans, and even former radicals, developed a renewed faith in the marketplace during the decade. ${ }^{79}$ Among baby boomers, a 1960s ideal of revolutionary change remained, but instead of engaging in mass protests, people began to evaluate their own lives and communities for things needing change. Plus, the baby boomers had grown up. They "turned inward," asserts seventies scholar Edward Berkowitz, in

\footnotetext{
${ }^{76}$ Patricia Harman, Arms Wide Open: A Midwife's Journey (Boston: Beacon Press, 2011), 233.

${ }^{77}$ Hale, 227; Schulman, 87; Gitlin, 429-430.

${ }^{78}$ Gitlin, 428 .

${ }^{79}$ Schulman, 29, xv.
} 
part because of a tough job market and in part because they were settling down to raise families. ${ }^{80}$ The introspective shift was also reflected in a "third great awakening" that occurred when millions of people either swelled the ranks of existing churches or became adherents of any variety of "New Age” religions. ${ }^{81}$

Perhaps the most significant force driving people back-to-the-land was the economy; the recession and inflation played a huge role in igniting the wave of urban outmigration. The New Deal order had maintained an abiding faith in the power of the federal government to regulate the economy and, more specifically, to prevent major economic downturns from occurring. The experience during the 1970s made Americans question this policy. Berkowitz writes, "Just as the thirties left a permanent mark in the way that Americans thought about the economy and policymakers used the federal government to stabilize the economy, so the seventies, with great inflation, worries about productivity, and the energy crisis, reoriented America’s approach to economic policy.” Unemployment, inflation, and recession caused take-home wages to fall over the course of the decade, which damaged America's position in the global economy. ${ }^{82}$ While only a fraction of the population responded to economic pressures by purchasing their own land, millions attempted to become more self-reliant and reduce costs by producing some of their own food and exploring energy alternatives. General Motors produced its “economy champ,” the Chevette, starting in 1975 and even explored marketing an electric car, the "Electrovette,” in anticipation of gas prices rising to $\$ 2.50$ per gallon. The Electrovette, like GM’s earlier and later

\footnotetext{
${ }^{80}$ Edward D. Berkowitz, Something Happened: A Political and Cultural Overview of the Seventies (New York: Columbia University Press, 2006), 159.

${ }^{81}$ The resurgence of Christianity occurred more among evangelicals than mainstream Protestants, and this fostered an anti-intellectualism that helped to feed the Right's resurgence. Schulman, 92-101.

${ }^{82}$ Berkowitz, 54-56.
} 
electric models, never made it to market. ${ }^{83} \mathrm{~A}$ canning lid shortage also became a hot issue in the summer of 1975 as the Ball Corporation, which claimed to be operating at full capacity, was unable to meet supply demands. The company blamed consumers for hoarding the lids while consumers accused the company of withholding lids to inflate the price. The problem became so great it garnered the attention of West Virginia Senator Robert C. Byrd and resulted in an investigation by the Federal Trade Commission. ${ }^{84}$

As it had during the 1937 recession, the 1970s' economic crisis spurred a renewed critique of centralization, which further eroded postwar liberalism. Not surprisingly, Ralph Borsodi gained an even broader audience, and his ideas about decentralization became widely disseminated through his own work and a new generation of adherents. Borsodi’s writings reached new audiences through the reissue of his book Flight from the City and through periodicals like Mother Earth News and The Green Revolution (subtitled "A Voice for Decentralism"). And in addition to Mildred Loomis, he attracted other noteworthy followers who helped to popularize and refine his ideas. Robert Swann, a long-time member of the peace movement who had been imprisoned during WWII as a conscientious objector, worked with Borsodi to refine and spread the concept of the community land trust and local monetary systems. A number of articles were published in The Green Revolution during the mid-seventies that described Borsodi’s “quiet revolution” against Wall Street and big government. ${ }^{85}$ During the 1960s, Swann helped to link non-violent civil disobedience with decentralization, and he later attracted new attention to E.F. Schumacher’s decentralist book Small is Beautiful, which argued

\footnotetext{
${ }^{83}$ Peter Valdes-Dapena, “GM’s Long Road Back to Electric Cars,” CNN Money, April 7, 2009: under "GM’s Long Road Back to Electric Cars,” http://money.cnn.com/galleries/2008/autos/0809/gallery.gm_electric_cars/index.html (accessed December 13, 2011).

84 "Investigations begun of lid shortage,” The Glenville Democrat, August 7, 1975; “Canning Supplies Remain Short," The Glenville Democrat, August 17, 1975.

${ }^{85}$ Mildred Jensen Loomis, “The Revolution is Here!” Green Revolution, July-August 1973, 10.
} 
against notions of basing standards of living on mass consumption of goods, continuous economic growth, and "large-scale systems" on the grounds that they were environmentally unsustainable and detrimental to society. ${ }^{86}$

Heathcote veterans were particularly attuned to decentralist arguments. Paul Salstrom and Marjie Shew used decentralist philosophy to inform their decisions to homestead or, at least, to encourage others to do so. Salstrom, who described himself as more of a back-to-the-land facilitator than practitioner, was fully engaged with decentralist arguments. From the late 1960s through the 1970s, he wrote articles in The Green Revolution that focused on the connections between land trusts, local currency, and social justice. ${ }^{87}$ Marjie Shew likewise recognized the connection that existed between her and earlier decentralists. Writing over the winter of 1970/'71, she remarked,

There is at Heathcote the nourishing consciousness of the history of the efforts of the School of Living. While each branch grows in its directionless push for fullness, the trunk carries from and to the roots. Those who have held the cause of decentralized living since before I was born pushed down into the dirt. Now their theories become the assumptions of my theories, and my life confirms the validity of their life. My God! The Borsodi and Loomis roots have grown into a truly decentralized community—a tree with an open center. $^{88}$

But she, like the other Heathcote residents, became weary of the constant stream of visitors to the community. Heathcote was intended to be an institution that could disseminate decentralist ideas

\footnotetext{
${ }^{86}$ Bob Swann, “The Land Question,” Green Revolution, October 1975, 5-6; Brown, 216; E.F. Schumacher, "Buddhist Economics," Green Revolution, January 1970/71, 15.

${ }^{87}$ Paul Salstrom, interview by author, Morgantown, WV, March 6, 2008.

${ }^{88}$ Marjie, "Letter to the editor," Green Revolution, December / January 1970/71, 9.
} 
to the public, so it was widely publicized and it received thousands of visitors per year. "It was pretty much agreed by everyone there that we could do our gardening, building, family raising and gardening much better without the crowds," she recalls. "But the Board of The School of Living saw [attracting lots of people] as our whole reason for being there.” ${ }^{89}$ She, like Joanie Goldsmith, eventually decided that homesteading would be better suited for raising a family than continuing to live on a commune.

Like the economy, the oil crises exacerbated Americans’ nervousness about their stability and the nation's economic position on the global stage. It also helped to elevate consciousness about Americans’ energy consumption, which in turn helped to swell the ranks of the burgeoning environmental movement. The movement had its roots in older conservationist impulses, new scientific research, the decade’s various social movements, and growing alarm at environmental degradation. Several factors led to the development of a mass environmental movement during the late 1960s and early 1970s. Reports had been released during the previous decade about nuclear fallout from tests, and a string of environmental disasters, from oil spills to a burning river, raised concern about environmental quality and human health. The publication of Rachel Carson's Silent Spring, a best-selling expose of the negative effects of pesticides on humans and the environment, was integral to the movement's development. The book mobilized both traditional conservation groups and individuals who had given little prior thought to environmental quality. ${ }^{90}$ The counterculture, which revered nature and voluntary simplicity, and other social movements helped environmentalists develop the political language and skills

\footnotetext{
${ }^{89}$ Marjie Shew, email message to author, July 1, 2009.

${ }^{90}$ Kirkpatrick Sale, Green Revolution: The American Environmental Movement, 1962-1992 (New York: Hill and Wang, 1993), 4-6, 18-19; Edward P. Morgan, The 60s Experience: Hard Lessons about Modern America (Philadelphia: Temple University Press, 1991), 232.
} 
necessary to advance their causes. ${ }^{91}$ The movement further coalesced with the first Earth Day celebration held on April 22, 1970. Demonstrations drew an estimated twenty million participants, and the activities, which involved everyone from politicians to young activists, were modeled on antiwar teach-ins. ${ }^{92}$

Environmentalism figured heavily into the back-to-the-land migration. Weary of public activism, homesteaders and communitarians began to focus more on how their personal choices and lifestyles could reflect their beliefs in sustainability. Although not all alter-natives articulated their decisions to homestead in terms of environmental views or their sentiments toward nature, they would all likely consider themselves environmentalists. Jeffrey Jacob identifies environmentalism as the unifying factor among back-to-the-landers who were still practicing in the 1980s and 90s. In fact, he views the back-to-the-land movement as a radical strain of environmentalism. By escaping the consumerist mainstream and engaging in at least partial selfsufficiency, many back-to-the-landers believed that they were modeling a new way of living in an eco-friendly fashion for the rest of the world. ${ }^{93}$ In Appalachia, "they had a vision of an intimate relationship with the bounteous mountain environment that could be achieved through economic self-sufficiency and separation from mainstream society.” Their attachment to the land and the mountain environment in some cases helped them to bond with native neighbors. In other cases, their reverence of the land caused divisions within the community as residents confronted decisions regarding land use and development, as will be discussed in subsequent chapters. ${ }^{94}$

\footnotetext{
91 Ibid., 12.

92 Ibid., 24-25.

93 Jacob, 5.

${ }^{94}$ Patricia D. Beaver, Rural Community in the Appalachian South (1986; repr., Prospect Heights, Illinois: Waveland Press, 1992), 120.
} 
At least one homesteader was very clear about having based his decision on environmental concerns. Although he had participated in the antiwar and civil rights movements, Paul Gallimore, the founder of Long Branch Environmental Education Center in Leicester, North Carolina, believed the environment to be "the ultimate cross-cutting issue."

Civil rights is civil rights ... but then war and peace issues are human rights, and then environmental issues and rights are the rights of future generations. If we don’t act responsibly now then future generations are going to suffer. And we're going to suffer with civil rights abuses and war issues and stuff. But then with pollution and habitat destruction and everything, future generations are going to suffer as well as other species. Other life forms are going to suffer. And I just thought, no, no. We've gotta be able to do better than this. So that's what really launched me in this direction. ${ }^{95}$

Other alter-natives might have been less clear about their environmental views as motives for moving back-to-the-land, but they were no less moved by the experience of living close to nature. For Lincoln County, West Virginia, alter-native Ric MacDowell, “being able to live in a much more natural environment has just been so important ... Not that this is pristine or untouched or anything, but to be able to have birds flying around and see the stars at night, and see a turkey or a fox . . . that has a real grounding, key kind of component of all this.”96

There were few instances of alter-natives citing Nixon's Watergate scandal as a predominate reason for moving although that event certainly contributed to the sense of dissatisfaction and distrust in America’s institutions and government. Patterson posits that it likely seemed “trivial” compared to the decade-long war in Vietnam. Still, as Bruce Schulman

\footnotetext{
${ }^{95}$ Gallimore interview.

${ }^{96}$ Ric MacDowell, interview by author, Hamlin, West Virginia, June 30, 2008.
} 
asserts, it “only intensified Americans' alienation from public life: their contempt for the secrecy, inefficiency, and failures of 'big government.'” One former political flunky-turnedback-to-the-lander, Karl Hess, was particularly frustrated with the political landscape; he cited his disillusionment with right-wing politics and the Republicans' alignment with the militaryindustrial complex as his reason for turning away. He believed that the New Left better represented "Old Right” values of "individual responsibility and self-determination" than did the right of the 1970s. To prove his point, he mentioned having read part of the Port Huron statement to Barry Goldwater without telling him who had authored the document. 'That's really wonderful!,’ responded Goldwater. ‘Did that come from the Young Americans for Freedom?’” When Hess told him the source of the document, Goldwater "was stunned." "But one of the great things about Barry Goldwater," Hess continued, "is that his thinking is not limited or directed by labels. And after a while Goldwater said, 'I don't care who wrote that statement, it's right..”97 While pessimism from energy crises, inflation, political corruption, and a decade of social upheaval certainly shaped the character of the back-to-the-land movement, optimism for a more sustainable future figured heavily as well. Social critics frustrated with the shift toward privatization contended that self-centeredness had replaced the 1960s-era sense of civic duty. But David Shi contends that while there were elements of "public indifference and private narcissism,” the 1960s search for "a more personally meaningful and socially responsible existence” continued. ${ }^{98}$ Postwar liberalism's optimism and reformist ethos did not die with the collapse of the New Deal order. It was carried into the backwater hills and hollers of Appalachia by people who wanted to commune with nature and to find authenticity and grounding in the rural way of life.

\footnotetext{
${ }^{97}$ Hess, "Presidential Speechwriter."

${ }^{98}$ Shi, 262.
} 
"Who ever found a hillside to be an obstacle for goats?": The Migratory Pull

“The best reason to know about Appalachia,” wrote Gurney Norman in the Whole Earth Catalog in 1970, was not the strip mining or the years of exploitation by coal companies or the outmigration of recent decades. It was because "the slate is clean there . . ain't no way to go but up.” The Appalachian writer had not "seen any [geodesic] domes on strip-mined hillsides yet," but he could "imagine them." Norman, who hailed from the central Appalachian coalfields, probably would not have believed at the time that over the course of the next decade, many Appalachian counties would host the very thing that he envisioned. His words were almost prophetic. Almost. Back-to-the-landers indeed came to the mountains and built geodesic domes, erected teepees, parked buses, and even lived in caves as they constructed new agrarian lives for themselves. Most, however, avoided the heart of coal country just like they avoided the southern hill counties that lay a bit too close to the epicenters of the previous decade's civil rights battles. ${ }^{99}$ Still, Divine Right's Trip, Norman's epic psychedelic tale about a mountain-born hippie who went on a journey to find himself only to find himself literally and metaphorically back in Appalachia, helped to put a countercultural spin on a place that Americans had come to know again during the late 1950s and early 1960s. ${ }^{100}$ The story was first published in Whole Earth Catalog, so he reached a wide audience of would-be and practicing homesteaders. His additional discussions of lingering folk traditions and "mysterious" mountains in the magazine brought

\footnotetext{
${ }^{99}$ Williams, 353.

${ }^{100}$ Since the late $19^{\text {th }}$ century, waves of social workers, folklorists, educators, and benevolent workers have called attention to Appalachia both for its poverty and perceived backwardness and for its folk culture. See Jane S. Becker, Selling Tradition: Appalachia and the Construction of an American Folk (Chapel Hill: University of North Carolina Press, 1998); Henry Shapiro, Appalachia On Our Mind: The Southern Mountains and Mountaineers in the American Consciousness, 1870-1920 (Chapel Hill: University of North Carolina Press, 1986); and David Whisnant, All That is Native and Fine: The Politics of Culture in an American Region (Chapel Hill: University of North Carolina Press, 1983).
} 
renewed attention to the region among baby boomers seeking to remake themselves as rural farmers or hoping to commune with nature. ${ }^{101}$

Norman understood that Appalachia had gotten a bad rap from the media in previous years. As mentioned above, eastern Kentucky, where the writer spent part of his childhood, had been the center of media attention during the early sixties as Presidents Kennedy and Johnson used the area to advance their campaigns and domestic agendas. During a visit to Appalachia in 1964, President Johnson announced his plans for "a program designed to bring the nine-state Appalachian region out of the economic doldrums.” ${ }^{102}$ Appalachia became virtually synonymous with poverty and backwardness, and the perception of it as a region of "others" was solidified in people’s minds. The 1967 fatal shooting of a Canadian filmmaker by eastern Kentucky native landowner Hobart Ison, a "mountain man” that the New York Times rather redundantly noted was “quick to anger,” did not help; this deepened existing notions about regional violence. These new images combined with old stereotypes to confirm what many already believed to be true about Appalachia: that its residents were backward, uneducated, prone to violence, and in desperate need of outside assistance. ${ }^{103}$

But there was another, more positive, side to Appalachian stereotypes that appealed to would-be homesteaders. The media also shaped ideas about Appalachian resilience and folk culture in the postwar era. Appalachia had come to be known as the "other America," and while that disturbed many local policymakers and regional residents, it appealed to baby boomers

\footnotetext{
${ }^{101}$ Gurney Norman, “Appalachia,” Whole Earth Catalog, September 1970: under “Appalachia,” http://www.wholeearth.com/issue/1120/article/225/appalachia.and.on.heroes (accessed December 20, 2011); Gurney Norman, Divine Right's Trip (1971; repr., Frankfort, KY: Gnomon Press, 1990).

102 "War on Poverty," Huntington Herald-Dispatch, April 25, 1964: under “President Johnson eastern Kentucky,” http://www.wvculture.org/history/government/waronpoverty.html (accessed December 19, 2011).

103 “Kentuckian Gets 10 Years in Jail For Killing Canada Filmmaker,” New York Times, March 25, 1969.
} 
seeking to reinvent themselves as part of the rural poor. ${ }^{104}$ Mountaineers were popularly known to be independent, self-reliant, and industrious, qualities attractive to people who wanted to rely as much as possible on their own efforts for survival. One article on the Alleghenies describes mountain residents in a stereotypical, albeit appealing, manner: "Mostly native-born, white Protestants, they've spent years in a geography and climate that invite an outdoor, un-confined lifestyle.”105 Pennsylvanian homesteader Nancy Bubel saw West Virginians in the same romantic light. She reshaped the potentially negative stereotypes of mountaineers' independence and poverty into something positive when she praised "the spirit of the mountain people" and noted "the remedies and herbs and cookery of people who for years have been making it on their own." ${ }^{106}$ Writing to The Green Revolution in 1974, Paul Salstrom reported that over 350 "hippie landowners" were present in Lincoln County, and they had moved there "neither to exploit nor change the hill people; they've come to join them, and learn their way of life, and eventually pass it on to their heirs." 107

Other newcomers believed that Appalachian residents were fairly open-minded. The reality of this perception depended on the neighbor and the location, but some areas were, and still are, reputed for having a high level of tolerance toward outsiders and alternate lifestyles. Becky Anderson, former director of Handmade in America, told USA Today that the diverse mixture of artists, musicians, writers, and dancers fostered cultural tolerance in western North Carolina. One Asheville alter-native who came to the region in the 1970s remarked, “There’s a

\footnotetext{
${ }^{104}$ Eller, 93.

${ }^{105}$ Elizabeth Brown, "The Southern Alleghenies,” Mother Earth News, May 1, 1988: under "The Southern Alleghenies," http://www.motherearthnews.com/Nature-Community/1988-05-01/The-Southern-Alleghenies.aspx (accessed August 9, 2008).

${ }^{106}$ Nancy Bubel, “The Peaceable Kingdom,” Mother Earth News, September/October 1971: under "The Peaceable Kingdom,” http://www.motherearthnews.com/Green-Homes/1971-05-01/The-Peaceable-Kingdom.aspx (accessed April 14, 2008).

${ }^{107}$ Paul Salstrom, “From Rugged Individualism to a Community Land Trust,” Green Revolution, February 1975, 7.
} 
tradition among the mountain people to live and let live.” The man was impressed by the fact that natives of the area had been more tolerant of his homosexuality than people in the larger cities of the North. ${ }^{108}$ Jayn Avery echoes the same belief: "Live and let live is the Appalachian philosophy. You don’t bother me, I don’t bother you.” 109

The folk revival, as mentioned before, exposed baby boomers to what they understood to be more feeling, emotive, and authentic sounds that came from marginal groups. The Newport Folk Festival helped to popularize mountain musicians like Jean Ritchie and Doc Watson. Folk festivals exploded during the 1960s and seventies and in some cases were almost overrun with countercultural visitors. Festivals became an important introduction to Appalachian culture for many back-to-the-landers. New and more established festivals, many of which suffered from low attendance during the 1960s, became wildly popular. “Appalachia is 'in’ and has been for five years or more," wrote West Virginia journalist David A. Peyton in 1975. "The arts, crafts, the Appalachian life style are a lure to those from outside the region.” Mountain State Folk Festival promoter Mack Samples "watched the mountain folk culture rise from an obscure remnant of past glories to an honored place among those seeking alternative life styles.”110 Joanie Goldsmith and several others from Heathcote attended Don West's inaugural festival at Pipestem in West Virginia, and that was where she first fell in love with the state. ${ }^{111}$ After moving to Lincoln County, she and some of her ex-Heathcote cohort traveled to the festival to sell their crafts and produce every summer. ${ }^{112}$

\footnotetext{
${ }^{108}$ Gene Sloan, "High-Country Hip: Nightlife and Art Scene Make Asheville, N.C., the Most Happening Town in the Blue Ridge," USA Today, October 3, 2003.

${ }^{109}$ Jayn Avery, interview by author, Floyd, Virginia, July 23, 2008.

${ }^{110}$ David Peyton, “Appalachian Culture Boom,” The Nation, November 8, 1975, 465-467.

${ }^{111}$ Goldsmith interview.

${ }^{112}$ Shew, email.
} 
The media played yet another role in luring people to Appalachia; popular movement literature like the Whole Earth Catalog included articles and advertisements that discussed and celebrated life in the mountains. In March of 1970, it published a feature on the Foxfire books, “a quarterly publication concerned with researching, recording, and preserving Appalachian folk art, crafts, and traditions.” These became wildly popular among homesteaders because they provided practical "how to" guides for producing crafts. Mother Earth News and The Green Revolution regularly featured articles highlighting the region's suitability for the movement. In 1970, shortly after Joanie and Lawrence Goldsmith had settled in Lincoln County, Lawrence wrote about his search for land in both publications. He had contacted the United Farm Agency in Kansas City, Missouri, for information on available, affordable land. The agency sent him flyers on two locations that caught his eye: "northcentral Pennsylvania and almost the entire state of West Virginia.” Considering such factors as “size, location, climate, price, farmable land, water, access roads, and neighbors,” Goldsmith set his sights upon southern West Virginia, and after meeting with some locals and the county agricultural extension agent, he settled on a "93 acre farm with a nice log house priced at \$2700 (less than \$30 an acre).” For Goldsmith, the dream of being a self-sufficient landowner became a reality in central Appalachia. Having worked up the deed through a local attorney, he cheerily forecasted, “soon we shall set up housekeeping and homesteading” deep in Lincoln County, West Virginia. ${ }^{113}$ Paul Salstrom later pinpointed Goldsmith’s Mother Earth News article as being the major impetus behind the group migration to Lincoln. In fact, the magazine aired parts of Goldsmith’s article on the radio to support its sales. The result was “a minor stampede” to the county. Indeed, Salstrom estimates

\footnotetext{
${ }^{113}$ Lawrence Goldsmith, "How to Buy Land,” Green Revolution, June 1970, 2; See also, Lawrence Goldsmith, “Locating and Buying Low Cost Land,” Mother Earth News, May/June 1970: under “Locating and Buying Low Cost Land,” http://www.motherearthnews.com/Modern-Homesteading/1970-05-01/Locating-and-Buying-Low-CostLand.aspx (accessed December 16, 2008).
} 
that between three and four hundred eager homesteaders moved into the county after the first neonatives, Ric MacDowell in 1968 and members of a Catholic Worker farm in $1969 .{ }^{114}$

Movement literature, along with conventional newspapers and magazines, called additional attention to Appalachia’s available land, communes, culture, environment, and homesteading activities. Mother Earth, The Whole Earth Catalog, The Green Revolution, and Communities all advertised available land or communes in the region that were seeking membership. "For lack of help to develop" their land, wrote one couple in The Green Revolution in 1973, "we now want to sell a piece of 30 acres ridge land . . for \$2,000."115 In 1976, they published another notice informing readers that West Virginia’s Department of Agriculture produced a bulletin that let people know of land for sale as well as “caretakers and hired hands." ${ }^{116}$ A number of communes published ads to recruit new members in the early 1970s; Free Growth commune in West Virginia sought "self-actualized people who wish to change their lives by developing non-role oriented, non-exploitative communal lifestyles.” Another upstart community in the Potomac Highlands of West Virginia hoped to found a "love-motivated, nonexploitative society" that could "relate to mankind and nature according to the Creator's Will." Like a number of other socially-conscious alter-natives, they also wanted to provide outreach for impoverished mountain residents. "Seeing a need for Appalachia aid,” wrote the authors, "we hope we can” use an existing handmade furniture business to "involve area people outside our fellowship in a Gandhi-type home craft industry.”117

\footnotetext{
${ }^{114}$ Paul Salstrom, “The Neonatives: Back-to-the-Land in Appalachia’s 1970’s,” Appalachian Journal 30, no. 4 (Summer 2003): 312, 316.

115 “Land for Sale, West Virginia,” Green Revolution, July-August 1973, 19.

116 "Homestead Schools and Apprenticeships,” Green Revolution, March 1976, 4.

${ }^{117}$ Dick Baker and Ross Anderson, "We are four adults," Communities 4, 1973, 55.
} 
Communities focused quite extensively on antipoverty initiatives that were being implemented by communitarians. The magazine regularly ran articles and advertisements that came from regional activist groups selling crafts as fundraisers. These ads drew attention to Appalachia as a place to settle; the image of handmade quilts, dolls, hammocks, and other items appealed to back-to-the-landers' romantic ideas about mountaineers' self-sufficiency. But they also raised awareness about the environmental and social issues confronting the region. The Grassroots Craftsmen of the Appalachian Mountains, based in Breathitt and Wolfe counties, Kentucky, sold quilts and clothing to raise money for local women. The Pike County Citizen's Association, which served counties in Kentucky, Tennessee, and Virginia, also sold locally crafted quilts to raise money. ${ }^{118}$ Communities also published a feature article on the efforts to form a Peacemaker Land Trust in West Virginia. It profiled Chuck Matthei's search for land in West Virginia and highlighted many of the problematic issues that mountain residents face in regards to landownership: inflated prices due to an influx of second homeowners and absentee ownership. While the farm had not yet been established, he hoped that some of the displacement of local residents could be ameliorated by allowing them "to stay on the land and teach the new people what they know. Many people who are older," it continued, "have amazing knowledge about how to live off the land, but have let it lie idle because of lack of young, strong bodies to help them." "Can we create an alliance between the grandparents and grandchildren to re-create community and self-sufficiency?" 119

The Green Revolution devoted a significant amount of attention to Appalachia through the mid-seventies because of the increased numbers of ex-Heathcote residents who had moved to the Mountain State. Attention to the region escalated even further after Paul Salstrom assumed

\footnotetext{
118 “The Grassroots Craftsmen” and “Pike County,” Communities 3, 1973, 28-29, 36-37.

119 "Trekkin with Chuck Matthei of Peacemaker thru West Virginia," Communitas 2, September 1972, 42-43.
} 
the editorship of the magazine and began to publish it out of Huntington, West Virginia. In this role, he increasingly called attention to both the beauty of the mountains and the struggles taking place within the region. He authored articles that discussed the history of self-sufficiency, the exploitation of labor and natural resources, the development of local land trusts, and some of his adventures in the Mountain State. He also devoted significant attention to coal strikes, much to the dismay of a man named Joe Ennis, who after reading the 1975 wildcat strike article complained that the magazine had morphed into an advocate for the "Red Revolution" instead of the "Green Revolution.", 120

Conventional magazines and newspapers also helped to call attention to Appalachia as a suitable place for would-be homesteaders. Connie Abraham recalls wanting to move to West Virginia after reading an article in Redbook magazine about a homesteading couple that had moved to Webster County. She and her husband actually sought out the people in the article so that they could "see how they found their land, how they managed what they did." ${ }^{21}$ The Associated Press ran an article featuring Lincoln County homesteaders Pete and Marjie Shew from Heathcote and another couple, Naomi and Harvey Cohen, who had moved to the state in the sixties to work as poverty lawyers. The article detailed their lives in the countryside, explored their decisions for moving, and highlighted some of the hardships that they had experienced. ${ }^{122}$ The Cohens had also been featured in an earlier article published by the Wall Street Journal on the decision of many former anti-poverty workers to remain in Appalachia as homesteaders. “Appalachia is the new home for many 'outsiders,"” it read, “who came here as warriors in the war on poverty and have stayed, partly to continue antipoverty work and partly to enjoy the

\footnotetext{
${ }^{120}$ Paul Salstrom, “The By-Laws of Trust in the Hills,” Green Revolution, September 1975, 7; “The 1975 Coal Strike,” October 1975, 2; “Son of Coal,” November 1975; Joe Ennis, “Paul,” Green Revolution, November $1972,4$. ${ }^{121}$ Abraham interview.

122 Stratton Douthat, “Back to the Earth,” Lincoln Journal, October 24, 1973.
} 
slow-paced life of Appalachia.” Thomas Thodenbaugh believed that many of the volunteers had been consumed with "hollow fever." They appreciated the simpler existence of rural life and understood that Appalachians were "much more capable of enjoying life" than city dwellers. ${ }^{123}$

The regional environment was a huge draw for back-to-the-landers and other alternatives. Western society has long regarded mountains as places where one can go to reconnect with the spiritual realm, to rejuvenate the soul, to restore the body and mind. For thousands of New Agers who helped shape the "third great awakening" of the 1970s, the Appalachian Mountains had special appeal. Many back-to-the-landers, particularly the Floyd County contingent, said they felt spiritually connected to the area. Some came because of Edgar Cayce predictions that maintained in the event of "earth changes," the Ridge and Valley portion of the Blue Ridge would be safe. ${ }^{124}$ Ruth Bason, a horse trainer and Cayce adherent from Raleigh, North Carolina, started one of the first communes in Floyd, Travianna, after seeing an advertisement for a farm in a North Carolina newspaper. Although Bason intended to found a Cayce-based community, she welcomed anyone who passed through her gate: serious communitarians, would-be homesteaders looking for land in the area, and dozens, if not hundreds, of transient young people. ${ }^{125}$

A second wave of homesteaders discovered the county in the late 1980s during the “harmonic convergence,” an event that Ruth Bason’s son, Will, described as “a worldwide celebration of planetary unity." Attendees would "pray, meditate, fast, sing, dance and practice whatever practice it is that brings us personally and collectively into resonance with the Earth

\footnotetext{
${ }^{123}$ Thomas Lindley Ehrich, "Home in the Hollows: Many Former Workers in the War on Poverty Settle in Appalachia,” Wall Street Journal, March 15, 1971.

${ }_{124}^{124}$ Melody Cochran, interview with author, August 3, 2011; A'Court Bason, interview with author, August 1, 2011.

${ }^{125}$ A’Court Bason interview.
} 
and receptivity to the power of Heaven." ${ }^{126}$ A New York Times article described it as an event that believers claimed would usher in "a quarter-century in which the earth may shake itself asunder unless enough of its inhabitants marshal their collective spiritual will or 'harmonic convergence' to neutralize the vibration.” The collective meditation event, which took place on Sunday, August 16-17, 1987, generally took place in "sites of great scenic beauty or religious significance,” like Mt. Shasta, Machu Picchu, and Floyd. ${ }^{127}$ And while it drew many newcomers to Floyd, apparently not all attendees were completely pure in heart; Bason's brother A'Court recalls that Travianna's tractor went missing after the convergence. ${ }^{128}$

Religious historian Rebecca Kneale Gould identifies homesteaders as "spiritual seekers," people who seek grounding and meaning outside of conventional religious institutions. They and other alter-natives operate within a Western tradition of viewing nature for its sacred or redemptive qualities and "find in nature," rather than in conventional religious expressions, "a source of truth, authority, and immortality.” ${ }^{129}$ People have long viewed mountains (and wilderness more generally) with ambivalence, feeling on one hand that they offer the opportunity for connection with the divine and on the other that they can be treacherous and terrifying. But during the mid-to-late nineteenth century the "sublime" wilderness "became domesticated." The writings of John Muir best represent this shift. While he celebrated mountains as divine cathedrals and articulated his experiences in the mountains of Yosemite and elsewhere as spiritual ecstasy, two of his predecessors, Henry David Thoreau and William Wordsworth, still found their mountaintop experiences to be both awe-inspiring and frightful. This ambivalence

\footnotetext{
${ }^{126}$ Will Bason, "Worldwide Celebration,” Floyd Press, August 13, 1987, 14.

${ }^{127}$ Walter Sullivan, "New Era Dawns—or Just a New Day,” New York Times, Aug. 11, 1987, C3; "Rangers at Mt. Shasta Brace for a 'New Age,"” New York Times, Aug. 16, 1987, 44.

${ }^{128}$ A'Court Bason interview.

${ }^{129}$ Rebecca Kneale Gould, At Home in Nature: Modern Homesteading and Spiritual Practice in America (Berkeley: University of California Press, 2005), 4-11.
} 
reflected long-standing attitudes about wilderness as places of temptation, sinfulness, and waste. A century and a half earlier, the explorer Robert Fallam had expressed the same ambivalence when he first gazed upon the "pleasing tho dreadful” Blue Ridge Mountains in southwest Virginia. The perception of domesticated mountains emerged amidst industrialization, the closing of the frontier, and the fear that America’s last wild lands were vanishing. "The sublime wilderness had ceased to be a place of satanic temptation,” writes environmental historian William Cronon, “and become instead a sacred temple, much as it continues to be for those who love it today."130

Isolation on the mountain was problematic for Thoreau, but not for Appalachian alternatives_at least not initially. One of the enduring stereotypes about Appalachia is that it has been culturally cut off from the rest of society because of its steep topography and lack of development. This notion, while grossly overgeneralized in many mid-century accounts of the region, still has an element of truth; the most rural mountain areas were often difficult to access, and even as late as the 1970s, many mountain residents still lived without electric power, running water, television, paved roads, or other modern amenities. But isolation, particularly for people weary of war, protests, and riots, was exactly what some alter-natives sought. After having been put into jail because he was a friend of a man who had witnessed an undercover policeman beating up a Vietnam veteran in Ohio, Kip Rondy, who had also previously won a lawsuit from Youngstown for being unjustly incarcerated, decided to leave Ohio the next day. ${ }^{131}$ Remoteness suited him, as it did Barbara Weaner, who came to West Virginia after deciding to prematurely

\footnotetext{
${ }^{130}$ William Cronon, “The Trouble with Wilderness; or, Getting Back to the Wrong Nature,” in Uncommon Ground: Rethinking the Human Place in Nature, William Cronon, ed. (New York: W.W. Norton, 1996), 70-77; Robert Fallam, “The Expedition of Batts and Fallam,” in West Virginia: Documents in the History of a Rural-Industrial State, edited by Ronald L. Lewis and John C. Hennen (Dubuque, IA: Kendall / Hunt Publishing Company, 1991 ), 4. ${ }^{131}$ Rondy interview.
} 
end her studies at Duke University. She recalled her future husband and another friend targeting the most isolated plots they could find.

When we were sitting in our friend John's house in North Carolina, looking at those maps of the Monongahela National Forest, he was explaining to us that on the map, all the green on the map was public land, and all the white on the map was private land. So when we were going to look for property, we should look for white land that was near green. Because that would mean that it was purchasable because it was private, but close enough to the forest that it was wild. And Scott looked at the map and said, 'Look at these little places. These are little white circles completely surrounded by green.' And there were a number of them on the map. And we decided that those were islands, private land that was surrounded on four sides by national forest. And Scott's strategy to buy land was to start in the southern part of the Monongahela Forest and drive to every one of those little white circles that was surrounded by green, and maybe something would come up. And this farm is one of those circles. ${ }^{132}$

Ron Juftes, a late arriver to Floyd, Virginia, eventually purchased additional tracts around his farm to provide a buffer between himself and other farmers who continued to rely on pesticides. He also wanted to prevent that land from further development and to allow it to return to a more natural state. ${ }^{133}$ Artistic alter-natives also valued isolation, but for a different reason: creativity. Jayn Avery asserted, “In its own way it’s isolated, and isolation culturally is considered a bad thing, but it's what artists need." ${ }^{134}$

\footnotetext{
${ }^{132}$ Barbara Weaner, interview with author, Randolph County, West Virginia, January 22, 2011.

${ }^{133}$ Ron Juftes, interview with author, Floyd, Virginia, July 16, 2011.

${ }^{134}$ Avery interview.
} 
But for many alter-natives, the notion of isolation was qualified. They wanted the feeling of remoteness while still having access to a community of like-minded people, cultural institutions, and marketing outlets. Both communitarians and individual homesteaders sought to create countercultural enclaves in the mountains. This is perhaps why there were so many group migrations to the region. As John Alexander Williams observes, back-to-the-landers often migrated to the region "in small clusters." ${ }^{135}$ One such group migration occurred in Wetzel County, West Virginia. Lynn Stasick, who moved there in 1972, was among a dozen or so individuals from New Jersey, Massachusetts, and other northeastern states who followed a friend to the county. Likewise, Jimmy Savely and his wife moved to Ashe County, North Carolina, after hearing about available land from friends who already resided there. ${ }^{136}$ Ruth Bason and, later, Ed Gralla did the same in Floyd; Gralla described himself as an “ambassador” for other newcomers. He helped them find and purchase land and introduced them to other in-migrants. ${ }^{137}$ Jock Lauterer and his wife Maggie joined Bill Byers and several others on a 300-acre farm in Rutherford County, North Carolina, in $1974 .{ }^{138}$ In addition, two neonatives, "Larry” and “Linda,” served as scouts for other would-be homesteaders. To fend off potential social isolation, the couple envisioned creating "a counterculture community in the mountains" that could be realized by enticing other like-minded individuals to purchase land nearby. ${ }^{139}$

A rather large group migration occurred in Lincoln County after the Goldsmiths’ arrival. Writing to The Green Revolution in 1972, Lawrence Goldsmith reflected on his experiences in West Virginia up to that point. He indicated that he and his "now exwife and acquaintance" were

\footnotetext{
135 John Alexander Williams, Appalachia: A History (Chapel Hill: University of North Carolina Press, 2002), 353.

136 Jimmy Savely, interview by Patricia Beaver, Ashe County, NC, fall, 2001.

${ }^{137}$ Gralla interview.

138 Jock Lauterer, Hogwild: A Back-to-the-Land Saga (Boone, North Carolina: Appalachian Consortium Press, 1993), 1-7.

${ }^{139}$ Beaver, 125.
} 
no longer lone ex-Heathcote pioneers. "April of 1970 I left Heathcote for the southern foothills of Appalachia. Drove my old truck through the hills and hollows and bought a beautiful 140-acre farm. Wife and child joined me and we began to get it together. No, that's not quite right. Wife and child and eight acquaintances joined me and none of us ever got it together [but] we sure learned a lot." ${ }^{140}$ As discussed above, the Heathcote situation had grown tiresome for many of its residents who were ready to settle down and have children. Paul Salstrom adds, "there was pretty much a Heathcote refugee situation in central Lincoln County in the early '70s. Kind of a pipeline from Heathcote to Lincoln County, and everyone wanted to have their own land and not live communally anymore." ${ }^{\not 141}$ Along with Lawrence Goldsmith, Paul became a key figure in attracting additional alternatively minded people to his new community.

Another positive feature of the Appalachian region was that it offered reasonable access to both eastern and Midwestern cities. ${ }^{142}$ This was important both for people who needed to transition more slowly from city to country and for artists and farmers who required access to urban markets. The convenient location allowed many homesteaders the opportunity to prepare for life on the land while keeping their jobs in cities. Alter-native Paul Edwards needed to maintain his urban job in order to pay for his family's homesteading dream. As he told the readers of Mother Earth News, he continued working to purchase their farm and livestock and to ready their home. Though he admitted his frustration with having to continue the "rat race," he cheerily projected that they had "12 to 18 months to go before" they could become "completely

\footnotetext{
${ }^{140}$ Lawrence Goldsmith, “Comfortin’ news from our W.Va. family,” Green Revolution, August 1972, 17.

${ }^{141}$ Paul Salstrom, interview by author, Morgantown, WV, March 6, 2008.

${ }^{142}$ The Encyclopedia of Appalachia maintains that proximity to east coast urban centers were a major draw. The same can be said for some of the rust belt cities like Cleveland and Cincinnati. Connie Ann Kirk and Dana L. Stuchul, "Back-to-the-Land Movement," in Encyclopedia of Appalachia, ed. Rudy Abramson and Jean Haskell (Knoxville: University of Tennessee Press, 2006), 295.
} 
self-sufficient.” ${ }^{143}$ Garry Biggers continued his job with a television station in Charlotte, North Carolina, until he and his wife completed their cabin in Marion County. ${ }^{144}$ The publishers of Communitas touted additional benefits for the six communes that had formed by 1972 in Virginia’s Piedmont and Blue Ridge regions. Their proximity to Washington D.C., Charlottesville, and Richmond allowed members the opportunity to sell their produce, find work, and keep themselves from "becoming too isolated and provincial." They also believed that cities provided them access to a "liberal-radical population" from which they could solicit new members. $^{145}$

In the September/October 1971 issue of Mother Earth News, John Miller published a piece on searching for land in and around colleges and universities across the country. Reflecting a general concern that back-to-the-landers had about potential culture clashes between themselves and rural residents, Miller suggested that homesteaders consider living in backwater college towns. He found those places to be more open-minded than the typical country town. “The rural university borough is frequently a delightfully kinkier version of the more common straight country town.” He opined that rural college towns were more tolerant of “alternative life styles” and thus would make good choices for homesteaders seeking freedom to live as they chose. ${ }^{146}$ John Alexander Williams observes that "Athens, Ohio, Morgantown, West Virginia, Boone, North Carolina, and Blacksburg, Virginia,” all became home to small populations of

\footnotetext{
${ }^{143}$ Paul Edwards, “Report from Them That's Doin”” Mother Earth News, March/April 1976: under “Them That's Doin," http://www.motherearthnews.com/Modern-Homesteading/1976-03-01/Report-From-Them-Thats-Doin.aspx (accessed April 13, 2008).

${ }^{144}$ Garry Biggers, interview with the author, Black Mountain, North Carolina, June 12, 2008.

145 "Virginia: The New Dominion of Community," Communitas, November 1972, 4.

${ }^{146}$ John Miller, "Living in a Small College Town," Mother Earth News, Sept/Oct 1971: under "Living in a Small College Town,” http://www.motherearthnews.com/Modern-Homesteading/1971-09-01/Living-In-a-Small-CollegeTown.aspx (accessed April 14, 2008).
} 
homesteaders. ${ }^{147}$ Floyd and Lincoln counties were both bedroom communities to a number of college and university towns, and this played a major role in attracting people to those areas. Floyd alter-native Ed Gralla, for one, selected that county in part because it was near Virginia Tech, Radford, and other schools. ${ }^{148}$ Many alter-natives eventually took advantage of the educational opportunities nearby; as they had children and discovered that self-sufficiency was a difficult goal to achieve, quite a few went back to college to either complete their degrees or receive additional education.

Other environmental factors played a role in the migration. While the back-to-the-land movement extended up into New England and Canada, Appalachia attracted people who desired a warmer climate. The growing season was longer and winters shorter. Avery considered settling in the Northeast but understood that Maine's "weather was not conducive to supporting yourself with goats and garden." ${ }^{149}$ The region’s topography could be a draw, although not without some qualifications. In November 1970, Mother Earth News published one of many articles on searching for land that mentioned Appalachia. “Don’t pass up rolling countryside or hillside acreage,” the magazine advised. "Those Appalachian farmsteads are not only beautifully scenic and remote...the land is generally excellent for gardening.” The magazine touted the benefits of the topography for soil drainage and fending off frost and added, "Besides, who ever found a hillside to be an obstacle for goats?”150 The availability of natural resources helped as well. John Vivian recommended Appalachia because "hill country land is cheap, water is plentiful, and there are many places where you can dig your own coal from surface seams that are too small for

\footnotetext{
${ }^{147}$ Williams, 354.

${ }^{148}$ Gralla interview.

149 Colleen Redman, interview by author, Floyd, Virginia, July 23, 2008; Avery interview.

150 "How to Find and Finance a Farm," Mother Earth News, November/December 1970: under "How to Find and Finance a Farm,” http:/www.motherearthnews.com/Modern-Homesteading/1970-11-01/How-To-Find-and-Financea-Farm.aspx (accessed April 14, 2008).
} 
commercial mining.” ${ }^{151}$ The more thoughtful homesteaders realized that they would need a reliable water source on their property, so the presence of mountain springs often served as the determining factor whether or not somebody would decide to purchase a specific plot of land. Floyd County sits atop one of several aquifers that underlay the Valley and Ridge Province, and because of this, rumor has it that all of the water flows out of the county. ${ }^{152}$ For people trying to escape urban pollution, the notion of abundant water untainted by industry would have had special appeal.

The final, and perhaps most important, pull factor was partially related to the environment and partially related to economic forces that had prompted over one million mountain residents to leave during the postwar era. Coal and farming had collapsed, leaving the region's young people faced with the unfortunate decision of either having to leave to find work elsewhere or stay and accept part-time work, limited farm incomes, or welfare. The mass exodus caused significant land devaluation in many places. And that was a major draw for young adults who had eschewed conventional labor in favor of voluntary poverty. Lawrence Goldsmith paid less than $\$ 30$ an acre for his land in West Virginia, while Salstrom paid $\$ 400$ total for over twenty acres of land. Lynn Stasick mentioned that he received his sixty-one acres of land in Wetzel County, West Virginia, for \$2,500. ${ }^{153}$ Another potential buyer reported finding 100 acres for $\$ 3,000$, while “some freaks nearby” purchased their “68 acres undeveloped land” for “\$1,500 cash.” The person also mentioned that a real estate agent had advertised "60 acres undeveloped

\footnotetext{
${ }^{151}$ John Vivian, “A New Year New Plans,” Mother Earth News, January / February, 1976: under "New Year, New Plans,” http://www.motherearthnews.com/modern-homesteading/practical-homesteading-zmaz76zhar.aspx (accessed December 19, 2011).

152 "Floydfest Grows Up,” Jambase, August 27, 2004: under “Floydfest Grows Up,” http://www.jambase.com/Articles/5462/FLOYDFEST-GROWS-UP (accessed December 19, 2010).

${ }^{153}$ Lynn Stasick, interview by author, Morgantown, WV, March 2, 2008.
} 
for $\$ 3,500$,” and then remarked, “These real estate agents carry the more expensive land!” 154 Further south in North Carolina, land prices were higher and rising rapidly due to the influx of second homeowners. Ashe County homesteader Jennifer Gardiner paid \$200 an acre for her land, and Jock Lauterer, who jointly purchased 300 acres with two other families, paid roughly $\$ 280$ an acre for his plot. ${ }^{155}$

Such inexpensive land seemed ideal for would-be homesteaders and communitarians who had rejected conventional employment in favor of partial or full self-sufficiency. Indeed, it enabled them to reject the trappings of modern life and to live, for a time anyway, as had many Appalachians half a century or more before. Cheap land also enabled them to continue their search for grounding and meaning through a perceived closeness with nature and as part of a like-minded community. Throughout the 1970s, as word spread about the region’s cheap land, hospitality, and friendly folk, entire countercultural sub-communities formed in counties like Lincoln and Floyd. Alter-natives labored and played together, helping each other to birth children, harvest crops, and build cabins, and celebrating seasonal rituals, weddings, and birthdays. In some ways, life seemed idyllic. But if cheap land provided these young counterculturalists with the opportunity to have their own farms and communes in Appalachia, it also signaled deeper structural problems that would eventually cause most alter-natives to move either literally or metaphorically back from the land, to borrow Eleanor Agnew’s phrase.

\footnotetext{
154 “From a Travelling Friend,” Communities 1973, 64.

155 Beaver, 125; Jimmy Savely, interview by Patricia Beaver, Ashe County, NC, fall, 2001; Lauterer, 3-4.
} 


\section{Chapter Three}

\section{"Sane and sound and working counterculturalists": Life on the Land}

Jason Rutledge grew up under his grandparents' care on a tobacco farm in the piedmont of Virginia. After graduating high school, he attended Virginia Polytechnic University on a football scholarship but suffered an injury that forced him out of the sport and, in turn, prompted him to reevaluate his life. "I wanted to have a job that was outdoors and that gave me a connection with nature and land," he recalled, so he considered forestry as a possible major. But he became disillusioned with the program because "the whole forestry education system was ... not about how to grow a forest, but about how to quickly and rapidly remove a forest and plant it back into a monoculture of single species pine.” That, and “it also didn’t pay very well.” Rutledge was faced with the decision whether or not to continue his education. He ultimately dropped out. Well aware that his action would result in his being drafted for the war in Vietnam, he enrolled in the Navy. His service took him to England where he remembered seeing his first Suffolk Punch horse, a draft breed known for its compact size and raw power. Having been raised around horses on his grandparents' farm, he felt drawn to the animal, and after his return to the United States, he purchased property in Floyd County, Virginia, where he began to work with and breed the animals. ${ }^{1}$

“These horses are one way of getting back to an old idea,” Rutledge told Jake Page of Mother Earth News in 1987. "It’s called independence." ${ }^{2}$ Draft animal power became an important component of Rutledge's mission "to take care of myself and be independent and be

\footnotetext{
${ }^{1}$ Jason Rutledge, interview by author, Floyd, Virginia, July 21, 2011.

2 Jake Page, “The Suffolk Punch,” Mother Earth News, July/August 1987: under “Jason Rutledge,” http://www.motherearthnews.com/Sustainable-Farming/1987-07-01/The-Suffolk-Punch.aspx (accessed May 4, 2012).
} 
self-sufficient. Grow my own food, provide my own fuel, even have my own transportation, and live my own life without dependence on the outside for very much.” Like others of his generation, Vietnam, social and economic problems, and environmental concerns became the major factors sending him back to the land. But his background was a bit different from that of the ex-urbanites who had little agricultural experience and swelled the ranks of the back-to-theland movement. Rutledge was a back-to-the-lander in the most literal sense, and as such, he was aware that one could achieve a sense of “dignity” through agricultural labor, self-sufficiency, and a close relationship with nature. ${ }^{3}$ Horses, and the homesteading lifestyle more generally, enabled Rutledge to redefine his life in opposition to the fast-paced, debt ridden, consumption-oriented society that surrounded him. For Rutledge, the animals symbolized his personal mission to reassert autonomy and self-determination in the wake of the war, social upheaval, and environmental disasters, and to find a sense of meaning and purpose in his labor and lifestyle.

Although back-to-the-landers have often been dismissed as backward, escapist, or nostalgic for an American agrarian past, most in fact would argue that they were just the opposite, that they structured their lifestyles according to the understanding that human consumption and the heavy reliance upon fossil fuels, particularly among residents of the western world, would almost certainly spell disaster for future generations. According to Rutledge, a panel discussion was held following the release of Rutledge's Mother Earth News article, during which a “USDA agronomist” called Rutledge’s preference for draft animals “an anachronism.” ${ }^{4}$ Unsure of the word's meaning, Rutledge "looked it up and found out that it

\footnotetext{
${ }^{3}$ Rutledge interview.

${ }^{4}$ When Rutledge told the story, he remembered that it was a USDA official who called his preference an "anachronism," and before learning the meaning of the word, wondered if he should "hunt him down and whoop his ass for calling me something that I didn't understand." There was a panel discussion printed in Mother Earth News following the feature on Rutledge, but I have not been able to identify which participant was the USDA official. Still, Rutledge's recollection underscores the frustration that he felt toward the government agency for its short-
} 
meant someone that was out of time with the present." He "brooded" about the label for many years but eventually concluded that the journalist was correct, only not in the way originally suggested. Rutledge believed himself to be out of step because he lived for the future instead of the present. ${ }^{5}$ Rutledge and thousands of others engaged in simple living viewed their activities as progressive and forward-thinking rather than nostalgic or backward. They believed that they were modeling new ways of living that might be more labor intensive, to be sure, but would ultimately prepare them for living in a post-fossil fuel world that would more likely be shaped by scarcity than abundance. It was better to learn to be self-sufficient by choice—and to have the luxury of time to experiment with different approaches to simple living — than to be caught without any survival skills during a complete economic meltdown. Echoing that sentiment, Tony Norris wrote in 1971, “I’m collecting tools now because if it all comes down, tools will mean survival." " 6 "The reason that I'm in the future and the reason that the principle core values of the back-to-the-land movement are in the future,” Rutledge later reflected,

are because of the reality of the finiteness of our resources. We don't have infinite amounts of oil to offset the value of human labor. We don’t have a healthcare system that will support the attending of people who have lived now for several generations eating foods that had ingredients in them that we couldn't pronounce. We're going to have to have core human skills to move society forward in the future. And the back-to-the-land

\footnotetext{
sighted acceptance of agribusiness as opposed to small-scale farmers, and for certain forms of technology that, while perhaps more efficient, would in the long run prove deleterious and detrimental to the environment. Rutledge eventually accepted the label but turned the meaning on its head by acknowledging that he was out of synch with his own time, but in a progressive, rather than regressive, way. He viewed his use of draft animal power as a linkage, or "bridge," between the past and the future that may not make sense to many people in the present but will ultimately serve the greater good as fossil fuels dry up. Rutledge interview; Jake Page, “The Suffolk Punch.”

${ }^{5}$ Rutledge interview.

${ }^{6}$ Tony Norris, “Letter,” Green Revolution, December 1970 / January 1971. A side note: although most homesteaders now believe that their earlier missions to achieve self-sufficiency were foolhardy, they still believe that "if it all goes down," they will be well equipped to navigate the change.
} 
group - the successful, surviving, the stuck-with-it back-to-the-land group-are the ones who are refining that skill set and are in that process carrying that forward to the future for the benefit of all of us. ${ }^{7}$

By recalling certain details of his past, like his frustration with the corporate focus of Virginia Tech's forestry program and his subsequent decision to drop out, the threat of the draft and his proactive enrollment in the Navy, and his interpretation of the word "anachronism," Rutledge provides counterpoints to his progressive narrative, moments or ideas that highlight what he views as the backwardness of American society compared to his proactive planning for the future. He juxtaposes his understanding of the world as it was at those various points in his life with his vision of the world as it should be: one that "includes draft animal power . . . solar energy and house construction, low impact development, site development, sensitivity to the place that you are in." 8 The world in the 1960s and 70s, according to Rutledge and many other baby boomers who decided to “drop out," was unacceptable in terms of the level of control that large institutions like universities attempted to exact over the populace. It was unacceptable because many people realized for the first time that fossil fuel shortages could cripple the nation and that the dollar, in fact, was not almighty. It was unacceptable because government officials, who were supposed to provide leadership in times of economic, social, political, or environmental crisis, still dismissed people with alternative visions as “anachronistic,” or worse. It is through such counterpoints that we begin to understand homesteading-and all of the activities that it involved — as a form of political dissent and measure of social reform.

\footnotetext{
${ }^{7}$ Rutledge interview.

${ }^{8}$ Rebecca Kneale Gould, At Home in Nature: Modern Homesteading and Spiritual Practice in America (Berkeley: University of California Press, 2005), 137; Rutledge interview.
} 
The strands of progressivism, idealism, and even to some extent pessimism that strung together the back-to-the-land impulse took many forms in Appalachia. The way homesteaders adapted to their new environments, built sub-communities, and began to form social and economic institutions in the mountains were reflections of their hope to construct workable alternatives to conventional mainstream culture. Homesteading or otherwise engaging in selfsufficient activities should be seen as acts of political dissent and the promotion of social reform, although that dissent was expressed in private choice as much as public action. For certain, some homesteaders and communitarians emulated earlier leaders like Helen and Scott Nearing or Ralph Borsodi by becoming public advocates for a lifestyle that they fervently believed could instill a greater sense of meaning and purpose in Americans' lives as well as offer a chance for greater levels of sustainability and social equality. But for other homesteaders, who were focused more on the practice rather than promotion of homesteading, political dissent was expressed in actions more than words. By understanding homesteading as dissent, alter-natives' choices to plow fields or log forests with draft animals begin to make more sense.

This chapter demonstrates that notions about freedom and independence, strength and vitality, and rebirth through closeness with nature shaped alter-natives' actions, reactions, social networks, and even their built environments. It first examines the movement's political and spiritual underpinnings to make the case for the movement as an attempt at social reform, a perspective that will need to be considered in subsequent chapters that examine the ways in which alter-natives created their sub-communities and began to integrate into indigenous social, economic, and political networks. A brief overview of life "on the land” follows. Practical applications of "green" technology, the development of support networks of like-minded individuals, and financial support—from families, employment, or, occasionally, the federal 
government — enabled some tenacious and enterprising newcomers to adapt and adjust to the lifestyle and to establish roots in their new communities. Those who stayed-and even a few who eventually left—helped to found new businesses and social groups that catered to the wants and needs of the countercultural in-migrants. These new initiatives provided additional incentive to remain and, in some cases, served as the foundations for the development of community-based organizations that worked alongside other indigenous groups who responded to some of the worst excesses of capitalism in Appalachia. ${ }^{9}$ Of course, many in-migrants' expectations bordered on the illusory, as popular movement literature and homesteading stories piqued the imaginations of weary urbanites working nine-to-five jobs or seeking to escape urban unrest and pollution. Many, excepting perhaps Rutledge and a few others with agrarian roots, came with relatively unrealistic expectations about what their lives would be like once on the land. For this reason, many people had left Appalachia by the mid-1980s.

\section{A “Green Revolution” in Appalachia}

Reflecting at a meeting of homesteading advocates, communitarians, and other "sane and sound and working counterculturalists” at the Heathcote Center in the fall of 1972, Ralph Borsodi repeated his call for a “Green Revolution”: a "social, economic, and political movement" that would begin "not with political agitation but with persuading people to" choose to "live in accordance with a culture fundamentally different from that which is now prevalent." The problem with the movement up to that point, he argued, was that it was too amorphous; it

\footnotetext{
${ }^{9}$ Richard A. Couto and Catherine S. Guthrie, Making Democracy Work Better: Mediating Structures, Social Capital, and the Democratic Prospect (Chapel Hill: University of North Carolina Press, 1999), 2. Couto and Guthrie identify these community organizations as "mediating structures," suggesting that they help to protect "consumers, workers, and others" from the "savage side of market capitalism." This chapter will only consider the beginnings of some of the organizations founded by newcomers that eventually served as mediating structures. Subsequent chapters will examine in more detail environmental organizations and other groups that were formed in response to a variety of issues.
} 
needed to "articulate both its principles and practices.” Borsodi saw great promise in the rising popularity of the Whole Earth Catalog and other magazines that catered to the simple life crowd, but he believed that the "sane" counterculturalists (as opposed to the "hippies, yippies and the crazies”) needed to settle on a "libertarian economy and polity" as opposed to a centralized strain of agrarian social reform. He hoped that organizations like the School of Living, with its focus on decentralization and "program of right-education and self-sufficient living on the land,” could steer people toward the former. "People can put the [School of Living's] program into action themselves directly,” he claimed. “They can organize land trusts . . . they can resort to an alternate currency and end inflation for themselves; they can form cooperatives to escape from the corporate state; and they can build homesteads on the land and avoid at least for themselves the economic and ecological catastrophe toward which the nation is heading.”10

Borsodi was fairly accurate in describing events that gradually unfolded in several dozen Virginia and West Virginia communities during the 1970s and early 80s. That was no mere coincidence; Borsodi remained a leading voice in the push for self-sufficiency until his death in 1977. His vision of decentralization influenced the new generation of homesteaders seeking to reject the "rat race” and the "urban and industrial quagmire.”" Editors of popular homesteading magazines likewise helped to re-popularize the concept of self-sufficiency among baby boomers, turning it into a catch phrase for the back-to-the-land movement. ${ }^{12}$ In 1973, John Shuttleworth, founder of Mother Earth News, told the Associated Press that the back-to-the-land movement, which had started its revival in the 1960s and quickly escalated into mass "hysteria," was composed of "people who are moving out onto the land . . . looking for self-sufficiency." Echoing other baby boomers who feared that their generation had lost self-determination, he

\footnotetext{
${ }^{10}$ Borsodi, "Green Revolution versus the Counter-Culture.”

${ }^{11}$ Borsodi, "Green Revolution versus The Counter Culture."

12 Robert Rodale, “Rural Renaissance on the Way,” Organic Gardening and Farming, September 1975, 44.
} 
conveyed his belief that the movement was an outright "rebellion against a system that wants us to be such complete 'nerds' that we can’t do anything, not even entertain ourselves without being plugged into an electronic tube.” While he voiced a degree of concern about the unsustainability of the movement at its current level of popularity, his magazine nonetheless encouraged the masses to push themselves toward independence by publishing how-to guides, interviews with high-profile homesteaders, and letters from “Them That's Doin.”13

In that same interview, Shuttleworth expressed his firm belief that homesteading was a form of political action and protest. But Borsodi, while espousing a libertarian ideology that shaped his personal homesteading activities and advocacy, seemed to be less certain about where the sentiments of the rest of the movement's populace lay. Indeed, his observation about homesteaders' inability to articulate a clear ideology holds some degree of truth, particularly if one considers the group of Appalachian homesteaders who were most familiar with his work: the ex-Heathcote residents who had migrated to Lincoln County, West Virginia. Joanie Goldsmith, for example, had spent over a year as a resident at Heathcote, but she described her homesteading activities as relatively “apolitical.” However, there were people like Paul Salstrom, Larry Lack, and Tony Norris who grounded their decisions to homestead in clearly defined political and/or religious philosophies. If Goldsmith was indeed apolitical, a point that will be examined below, then Salstrom was on the exact opposite of the spectrum. His activism stemmed from early involvement in environmental and peace initiatives, and his concern for a broad range of social justice issues, ranging from labor organizing to land reform, was evident during his tenure as editor of the Green Revolution. Many of the articles that he chose to print in the magazine were political in nature, particularly in comparison to those being published in the Mother Earth News at the same time. If this small sampling and the eclectic array of transient

\footnotetext{
${ }^{13}$ Stratton Douthat, “Back to the Earth,” Lincoln Journal, October 24, 1973.
} 
residents at Heathcote in the 1960s and early 1970s is any indication, there is little wonder that Borsodi had trouble predicting which direction the back-to-the-land movement would take politically: toward centralization, decentralization, or adrift without any clear ideology at all. ${ }^{14}$

Borsodi is not alone in his questioning of the politics of baby boom back-to-the-landers. Leading scholars have also wrestled with the question of whether or not the back-to-the-land movement was purely reactionary — that it was just a "flight from the city" with loose ideological underpinnings — or whether it should be viewed as a more organized, comprehensive form of social protest with central leaders and a clear agenda. Vivian Ellen Rose’s dissertation understands the entire $20^{\text {th }}$ century back-to-the-land impulse as a measure of social reform, but the study acknowledges the limitations of leaders' efforts to build anything sustainable and widespread. If there was any continuity between the different waves of homesteading from the late $19^{\text {th }}$ century until the 1970 s, then it was due to the women who operated in support of male

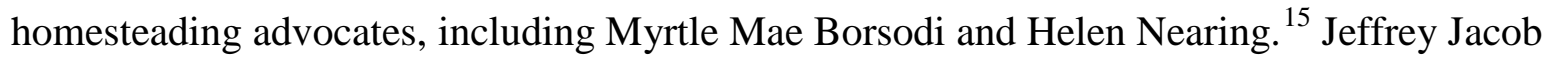
believes that the movement was a form of lived activism, although he places it within the context of the larger environmental movement rather than identifying it as a separate and distinct phenomenon. Homesteaders saw themselves as "actually demonstrating, or trying to demonstrate, a sustainable way of life on their smallholdings,” rather than picking or choosing certain campaigns to which they would devote time, money, and energy. ${ }^{16}$ He questions whether or not they were drawn into activist roles once engaged in homesteading. The grim realities of

\footnotetext{
${ }^{14}$ In a reflective piece on the Heathcote community, Larry Lack observed that part of what had led to a general decline of membership in the early 1970s was the lack of commitment to "defining and carrying out the work of the School of Living." Only "some," he claimed, were truly committed to Borsodi's vision of decentralization and social reform through simple living. Larry Lack, "The Heathcote Experience: Personal Reflections,” Green Revolution, December-January 1971.

${ }^{15}$ Vivian Ellen Rose, "Homesteading as Social Protest: Gender and Continuity in the Back-to-the-Land Movement in the United States, 1890-1980” (PhD diss, State University of New York: Binghamton, 1997), 41.

${ }^{16}$ Jeffrey Jacob, New Pioneers: The Back-to-the-Land Movement and the Search for a Sustainable Future (University Park: Pennsylvania State University Press, 1997), 5.
} 
rural areas as national "sacrifice zones" occasionally elicited activist responses from the inmigrants who had moved in search of a higher quality of life. He discovered that homesteaders got involved with local and national initiatives but perhaps not as often as one might expect. Most of his respondents "sympathized" with activist groups, but less than half provided financial support or belonged to at least one activist organization. Still, he concluded, "most, or even a majority, of back-to-the-landers do not have to be country activists for the movement itself to posses an activist quality.” The act of engaging in simple living and self-sufficiency was a "quiet" but "broad-based protest" against flagrant consumption and the "irrational materialism of urban life." 17

Rebecca Gould and Dona Brown provide deeper analyses of homesteading as a form of activism or political dissent. Gould, whose study explores contemporary homesteaders’ religiosity and the spiritual connections between themselves and high-profile historic figures like the Nearings, argues that practitioners are not as overtly political as their predecessors who homesteaded earlier. They "still long for reform and seek the experience of community and intimacy in the face of threats to stable social structures,” but they tend to avoid advocating sweeping social programs like New Deal-era resettlement communities. ${ }^{18}$ It seems that the transition away from arguments for centralized homesteading may have, in fact, been rooted in the 1970s. ${ }^{19}$ Dona Brown finds that "some new homesteaders saw the act of homesteading . . . as a political act in itself-perhaps the last political act left to them” in light of the government crackdown on radical action, particularly after Nixon’s election. But Brown believes that the

\footnotetext{
${ }^{17}$ Jacob, 178-179, 3.

${ }^{18}$ This does not mean that the alter-natives did not involve themselves in regional or national initiatives after moving to Appalachia. Some of the newcomers, in fact, became very involved with issues ranging from political corruption to surface mining, as we shall see in subsequent chapters. Gould, 194.

${ }^{19}$ There is currently very little discussion regarding centralized government planning for self-sufficient or ecofriendly communities, but the vision for independent collectives in the form of intentional communities or ecovillages is still very much alive and part of the modern-day back-to-the-land discourse.
} 
variety of solutions that high-profile homesteaders offered to the public narrowed somewhat with the 1970s revival in comparison to earlier back-to-the-land impulses. From the early to midtwentieth century, simple life advocates had promoted both centralized and decentralized backto-the-land visions of social reform. But the decentralist argument became much more popular in the 1970s than centralized back-to-the-land planning. ${ }^{20}$ Brown finds that Scott Nearing, for example, remained dedicated to “centralized global socialism,” but his political leanings were virtually absent from the interviews he provided to Mother Earth News and other movement literature. Indeed, he was often promoted as "the embodiment of the values of middle America." Stripped of his politics in what was arguably the most popular homesteading magazine, he and his wife simply became “older and more experienced versions of their fans.” The implications of this lack of consideration for the broad range of historical back-to-the-land efforts meant that those practicing in the 1970s were left "in great need of models" from which to learn. ${ }^{21}$

\footnotetext{
${ }^{20}$ Brown and Gould differ on this point. Brown argues that Borsodi's decentralized vision gained prominence during the 1970s, while Gould believes that the "countercultural homesteaders tended to prefer the Nearings' example over the Borsodis'”. The latter contends that it was the Nearings' radical politics—he was a socialist—that appealed to younger homesteaders who had been active in 1960s social movements. But Paul Salstrom, who worked with Borsodi on issuing an alternative currency called the Constant, maintains that the Nearings were far more popular than Borsodi predominately because of "their well-documented example" of homesteading, and that their socialism "was (and is) irrelevant to their popularity." See Dona Brown, Back to the Land: The Enduring Dream of SelfSufficiency in Modern America (Madison: University of Wisconsin Press, 2011), 215-217; Gould, 296; Paul Salstrom to Jinny Turman, comments on Chapter Three, notes in the author's possession.

${ }^{21}$ Brown discusses the implications of this individualist leaning, but she offers relatively little explanation as to why the libertarian strain of homesteading dominated popular literature. Other scholars like Bruce Schulman, Edward Berkowitz, and Todd Gitlin have chronicled a general shift toward the personal, the private, and the small scale during the 1970s. This shift was a response to larger societal disillusionment that came with war, an obtrusive government, and dramatic demographic and social changes taking place in both rural and urban areas. In urban areas, part of this was due to the fact that many average Americans had grown tired of social engineering and felt threatened by some of its effects on the availability of jobs, their sense of community cohesion, and their children's access to "good" (and largely white) schools. Rural areas experienced their own issues with big government and other highly centralized institutions; Kanawha County, West Virginia, skyrocketed into national consciousness as some of the county's rural residents protested the use of literature textbooks that promoted multicultural learning. Of course, economics also played a factor in both rural and urban settings, as inflation made people question the viability of Keynesian solutions to economic stabilization. See Brown, 215-222; Edward D. Berkowitz, Something Happened: A Political and Cultural Overview of the Seventies (New York: Columbia University Press, 2006), 169177; Todd Gitlin, The Sixties: Years of Hope, Days of Rage (New York: Bantam Books, 1987), 428; Bruce Schulman, The Seventies: The Great Shift in American Culture, Society, and Politics (Cambridge, MA: DaCapo
} 
One "Plowboy Interview" in Mother Earth News provides a regional, and rather unique, example of this individualist trend even among former conservatives who might have disdained a strong central government's domestic programs but accepted its domination in foreign affairs. Karl Hess produced one of the more interesting homesteader "conversion narratives," as Gould calls them, given his high-profile and politically conservative past. ${ }^{22}$ In a 1976 interview with Mother Earth News’ Anson Mount, Hess detailed the process through which he transitioned from GOP darling to libertarian and simple life advocate. ${ }^{23}$ After Thomas Dewey’s second loss in 1948, Hess had begun writing “speeches for the Republican National Committee” and GOP big shots like Richard Nixon, Gerald Ford, and Dwight Eisenhower. He achieved his greatest level of notoriety as Barry Goldwater’s chief writer during his presidential campaign in 1964, but Goldwater's loss freed Hess to attend more closely to some of the ideas being circulated among student radicals. He was especially drawn to the New Left’s ideas about “individual responsibility and whether or not we should stick our noses, and our guns, into other countries’ business.” Oddly enough, he began to believe that the New Left espoused the values and ideals

Press, 2001), Carol Mason, Reading Appalachia From Left to Right: Conservatives and the 1974 Kanawha County Textbook Controversy (Ithaca, NY: Cornell University Press, 2009).

${ }^{22}$ Like Karl Hess, many Appalachian alter-natives engaged in what Gould has labeled as an important "meaning making” process by reflecting on their experiences and presenting those reflections to the public. It is through their written texts, songs, interviews, and other public presentations of the self that they conveyed how they exchanged a life of frustration amidst mainstream culture for the return to a simpler, independent, and more grounded existence in nature. She contends that these stories resemble the "conversion narratives" of traditional religions, meaning that they are "stories that have to be told because they bear witness to right ways of living and," importantly, "encourage others to follow suit." Some Appalachian alter-natives became prolific writers and engaged in these types of activities. A few published books about their homesteading experiences, while others wrote letters to the editor, appeared in newspapers or magazines, or wrote songs that celebrated their decisions to give up consumption and subservience to nine-to-five jobs in exchange for freedom through austerity. Some of these measures were created in an attempt to call attention to the choices that people have regarding their consumption patterns and complicity (whether intentional or unintentional) in maintaining dominant power structures and inequality, while others were quieter, more reflective forms of self-analysis that avoided any overt advocacy of social reform measures. Still, by producing these works, homesteaders had attached meaning to their own experiences while simultaneously constructing models for others who might have been considering following a similar path. Gould, 25-30.

${ }^{23}$ Having started his career as a reporter for Mutual Broadcasting at fifteen years of age, he worked through various Virginia and Washington newspapers and was fired from a job with the Washington Daily News after refusing to write the obituary for Franklin Delano Roosevelt, who he believed "was the first real social fascist on the North American Continent." Had Goldwater won, Hess believes he would have gone on to serve as Deputy Secretary of Defense for International Affairs. At the time, he claims he was a "very dedicated Cold War advocate." 
of Old Right leaders like Robert Taft and other “old-fashioned American conservatives.”24

Between 1964 and 1968, Hess grew increasingly libertarian and, simultaneously, disillusioned with Washington politics and the town’s middle class “social structure.” Two events prompted him to move to West Virginia. The first was his decision to purchase a motorcycle, which went against middle-class notions of propriety. His neighbors' scathing reaction to the bike prompted him to see "for the first time — and very clearly—-that” they “didn't care whether or not I was capable or honest or loving, what they cared about was how I looked.” The second was his decision to move to the Adams-Morgan area of D.C., where he worked with the Institute for Policy Studies, which, he claimed, “advocates a much more decentralized society than any other political faction.” It was through the Institute that he began applying appropriate technology to community development. ${ }^{25}$ The high crime rate, however, pushed him out of the city, and after having been robbed repeatedly, he and his wife said, “To hell with it, we won’t stay here another night.” They "threw what was left" of their possessions into a truck and "drove out to the few acres Therese happened to own . . . in West Virginia.”26

Hess's decision to turn away from the middle class and to homestead in the Mountain State was born of frustration with the constraints of middle-class propriety and urban

\footnotetext{
${ }^{24}$ Hess read a portion of the Port Huron statement to Goldwater without first mentioning the source and claims that Goldwater was intrigued by the ideas being presented. "That's really wonderful!" he said. "Did that come from the Young Americans for Freedom?" Hess recalls that Goldwater "was stunned” when he learned the truth, but "after a while he said, 'I don't care who wrote that statement, it's right.'” Hess' emphasis on individual freedom and responsibility led him to sympathize also with the more radical elements of the New Left, including the Weathermen. Hess eventually became a key leader in the development of the libertarian party. See Brian Doherty, Radicals for Capitalism: A Freewheeling History of the Modern American Libertarian Movement (New York: Public Affairs, 2007), 345-353.

${ }^{25}$ The concept of "appropriate technology" is credited to economist E.F. Schumacher, whose book Small is Beautiful articulated a new vision for small-scale production based on a blending of technology suited to localized needs and resources. See E.F. Schumacher, Small is Beautiful: Economics as if People Mattered (New York, NY: Harper \& Row, 1973).

${ }^{26}$ Karl Hess, “The Plowboy Interview: Karl Hess,” Mother Earth News, January/February 1976: under "Karl Hess,” http://www.motherearthnews.com/Green-Homes/1976-01-01/The-Plowboy-Interview-Karl-Hess.aspx (accessed April 14, 2008).
} 
degeneration, but having spent almost his entire life in politics, he was able to clearly articulate the political underpinnings of his decision to reject mainstream society. Another West Virginia homesteader, Mike Kreyche, was equally vocal about his dissatisfaction with American involvement in overseas affairs when he published an article in the Green Revolution. "The most important motivation for me has been the desire to break with the injustices built into society, to try 'creating a new society within the shell of the old,"” he wrote, quoting Peter Maurin, a leading figure in the Catholic Worker movement. Kreyche had developed a heightened sense of social consciousness during college and later traveled to Latin America, where he had witnessed "how much the industrialized world dominated the life of poorer countries." He realized that he "could not resume a conventional life" in the United States "without being at best an unwilling agent of institutional injustice." Homesteading became his primary "means of escaping a guilty involvement in institutional injustice.” Although he asserted that he could not claim to be "entirely non-oppressive" in his lifestyle (he confessed that he still bought bananas and used money for a few necessities), he was living as lightly as possible off the grid and refusing to pay income taxes, a decision that he and Hess both made after their respective moves. "I've come to love the soil," he concluded in his report, "and have gratified the delight I've always had in working with my hands. I've also been stimulated intellectually and have found in this way of life a wholeness which satisfies me more than anything else.”27

Hess and Kreyche were very clear about their political motives for moving back to the land. But what about those individuals like Joanie Goldsmith or countless others who drifted into the lifestyle via friends or fortuitous circumstances and might not have been as reflective or articulate—or public—about their decision? For people who were committed to the lifestyle and

\footnotetext{
${ }^{27}$ Mike Kreyche, “Why Homestead?” Green Revolution, December 1975.
} 
remained on the land for an extended period of time (as opposed to the thousands of "transients" who dabbled in homesteading for a few months to a year or so), Gould argues for homesteading as a form of "lived religion," a perspective that is important to consider when trying to understand how and why a movement that seems akin to retreat should be understood instead as a push for social reform. Homesteaders' view of nature as "sacred, beneficient, and redemptive” bears striking resemblance to the ways in which members of more conventional faiths view a person or thing as the center of morality. Because they were products of the largely Christian culture in which they were raised, homesteaders took those dominant religious structures and reconfigured them for their own purposes. ${ }^{28}$ Gould finds that the spiritual views of contemporary Maine homesteaders share many themes with members of conventional religious institutions. Homesteaders typically have rituals in which they participate; a shared sense of tradition based on the insights of spiritual forbears such as Henry David Thoreau; a commitment to community and "concerns beyond the self”; conversion narratives; and clear distinctions between their own alternative culture and the culture of conventional, mainstream America. They also, significantly, view their work as an expression of dissent against dominant social structures. ${ }^{29}$ How does this happen? People attach meanings to the work that they do. Self-chosen farmwork becomes a ritualization of a new way of life, and the work becomes an expression of dissatisfaction with other types of labor that may be seen as subservient, environmentally or socially destructive, or contributing to a corrupt system that perpetuates inequality. ${ }^{30}$

\footnotetext{
${ }^{28}$ Gould, 3-5.

${ }^{29}$ She also argues that homesteaders have constructed a formal, nature-based belief system that goes beyond mere "lifestyle enclaves" that tie people of a certain socio-economic status together through consumption patterns or recreational activities. These enclaves do include environmental sensibilities and a love for the outdoors, but that explanation falls short for a population that structures its entire existence around the home and its place in nature. Gould, 96-101.

${ }^{30}$ Gould argues that homesteaders' emphasis on the home and their attentiveness to daily activities should be understood as a form of ritualization. In other words, such expressions should be viewed as a meaning-making
} 
For these reasons, this study argues that homesteading is a form of social protest, even when its practitioners might not articulate their political leanings or advocate for the lifestyle on a public platform in the way that Borsodi, Hess, Kreyche, the Nearings, Salstrom, or some of the other movement supporters did. A discussion of their values and their beliefs about work and homelife, and those activities' relation to nature, is necessary to understand why they made the choices that they made once in Appalachian communities. The conversion narratives typically reflect practitioners' focus on independence, but they also integrate themes of home and its place in the environment as a way to promote social reform. Home became the means through which alter-natives expressed and asserted their independence. To homestead means to base one's life and livelihood out of the home, "a home," says Gould, “consciously built with attention to a particular place in the natural world.” Emphasis on the domicile and its relationship to nature that is found in so much of the movement literature was a reflection of practitioners' intent to regain autonomy—it allowed them, in theory, the chance to escape the seemingly never-ending cycle of subjection to the demands and expectations of family, society, government, and market—and to find peace and order in every aspect of their lives. ${ }^{31}$

Activities surrounding the home became the defining features of the homesteading lifestyle. The hope was to base one's entire existence, or as much of it as possible, out of the home: the production of food, clothing, and shelter; childbearing and childrearing; education; and social life. Although there was a great deal of variation between how alter-natives carried out

process that stems from homesteaders' attempts to redefine their lives in opposition to a mainstream culture that celebrates consumption, exploitation, and religious beliefs that are by and large divorced from nature. Homesteaders engage in tedious, laborious work because of the experiences of transcendence that it can afford them. Through their labor, they have the potential to experience a sense of "expansion or dissolution of the self" amidst nature.

Sometimes people experience this transcendence as expanded consciousness; they see their physical and spiritual selves become part of the nature that surrounds them. In other cases, homesteading activities enable them to experience a feeling of dissolution of the self that results in their ability to forget for a time current circumstances and concerns. See Gould, 64-70.

${ }^{31}$ Gould, 69. 
their vision of structuring life around the home or commune, there was a relatively consistent desire to attend closely to daily tasks at the home and on the farm, to savor those experiences, and to recognize and appreciate how those activities connected the individual to the surrounding natural landscape. Brown goes so far as to write that homesteaders in the 1970s were even likelier than earlier generations to live in the most primitive conditions possible. Part of this, she says, was simply due to a lack of money. But they were more likely motivated by a desire to reject any and all trappings of modern life, even if that meant trekking to an outhouse through several feet of snow. ${ }^{32}$

Floydian author Fred First's writing exemplifies homesteaders' pursuit of freedom from the corporate grind by attending to the home and its place in nature. In his introduction to Slow Road Home: A Blue Ridge Book of Days, he explained his move to the county in the context of his search for grounding and meaning in everyday tasks and in the surrounding environment. Like Jason Rutledge and other simple life practitioners, First juxtaposed his new life of slowness and attentiveness to the "hurry-sick pace of corporate imperative.” He speculated about what his new role would be since he had foregone conventional labor in exchange for life on the land. My work would be in getting to know my part here at home—a home where I did not fully belong those mornings as the valley took shape and its textures appeared softly in the first sun of dawn, flaming red against the barn roof. For the days ahead, my goal each foggy morning and everynight under the stars would be to find wonder and meaning in whatever kind of light the days or nights would bring.

Nothing would be ignored, no thing trivial: not the wind or the woods; not the rain or the water underground or the creeks. The garden, the forest, the sounds of summer, the wonders of imagination, the familiar unnamed smells of the seasons-all of these

\footnotetext{
${ }^{32}$ Brown, 222.
} 
common elements just beyond the front steps would be objects of curiosity and importance.

His life as a homesteader would be spent "sitting still on the ridge, walking by the creek, leaning on my rake in the garden.” Over time, his attention to nature nurtured his creative sensibilities and, in essence, transformed him. "In the slowness, in the stillness, words and images came," he continued, “not every morning but most—a kind of manna I had never known.”33 For Fred First, fulfillment came when he rejected the fast-paced corporate life, reoriented himself toward the home, and took the necessary time to observe nature and his place within it. The book is about self-discovery, first and foremost, but it also provides a subtle lesson to readers: slow down, pay attention to your natural surroundings, and you too can find peace, order, and fulfillment.

From Corn Cribs to Cabins: Settling In

It is important to consider the philosophical dimensions of homesteading and communal activities as they relate to nature, for that helps to explain the great lengths to which many alternatives in Appalachia went to construct dwellings and cultivate, as well as support, their smallholdings. From cabins to food choice, the hope for reducing dependency on the mainstream economy and bringing themselves as close as possible to nature remained a constant. The intense physical labor, the trips to the outhouses, the stripped down and bare bones existence, the attention to the "unnamed smells of the seasons": all of these had significance for homesteaders who fervently believed that their newly adopted lifestyles could change them from within and, slowly, steadily, reshape the world without.

\footnotetext{
${ }^{33}$ Fred First, Slow Road Home: A Blue Ridge Book of Days (Floyd, VA: Goose Creek Press, 2007), 3-4; Gould, 25.
} 
For many homesteaders and communitarians, the earliest months spent in Appalachia were done so in the most meager conditions. A number of people purchased or rented land with few or no livable structures on them. ${ }^{34}$ Several moved onto their land with little more than tents, teepees, or motor vehicles. Jan Salstrom spent well over a year living in a teepee on an isolated ridge in Lincoln County. ${ }^{35}$ Rob Yard, an ex-Canadian flutemaker who moved to Floyd, lived with his young family in a "converted school bus” on a communal piece of land. The bus had “no electricity or indoor plumbing,” and his family slept "together in the same bed.”36 This dwelling choice was popular; even Mother Earth News featured an article that instructed readers how to “custom design your own mobile home.”37

Others camped out in root cellars, dilapidated cabins, or corn cribs. Before moving into her teepee, Jan Salstrom lived in an old barn that sat on a friend's plot of land. She and two others had arrived to the county in 1974 hoping to be "as self-sufficient as possible” in order to avoid becoming “dependent on a failing system.” They spent the winter of that year sleeping in the hayloft and used a 55-gallon drum to burn wood for heat. ${ }^{38}$ After purchasing their land in central West Virginia, Connie Abraham and her spouse moved into a root cellar, “an eleven by fifteen building," located on the property. Her neighbors had given them “an old coal burning stove that was full of holes" as well as "some old rugs to get started.” The couple had their first child in the root cellar, but when Connie became pregnant with their second, they decided to

\footnotetext{
${ }^{34}$ Some socially conscious homesteaders even struggled with the concept of land ownership. They were aware that purchasing land could elevate taxes and had the potential to squeeze out local populations. Chuck Smith, who moved to Lincoln County as part of the Catholic Worker movement, worried that buying land would cause price increases, which could in turn have the adverse effect of pushing locals off the land and hindering their ability to be independent. This issue will be discussed in later chapters.

${ }^{35}$ Jan Salstrom, interview by author, Morgantown, WV, November 20, 2008.

${ }^{36}$ Seth Williamson, "The New Pilgrims of Floyd County,” The Roanoker April 1981, 24.

${ }^{37}$ Don Stephens, “Custom Design Your Own Home,” Mother Earth News 8, March 1, 1971.

${ }^{38}$ Jan Salstrom, email to author, July 9, 2008; Jan Salstrom, interview by author, Greenville, NC, May 13, 2012.
} 
move "up the holler a little farther to a corncrib, which was pretty much the same size, except that it had a loft, so it afforded us a little more space with two kids."39

Living in such meager conditions did not typically last long; alter-natives quickly began refurbishing existing structures or building new ones on their land. Transforming their old, worn out farms into workable homesteads and communes could be a long, arduous process, full of trials and triumphs. Jan Salstrom detailed the process of building cabins in Lincoln County: "So we did saddle notches" on the ends of the logs, "which the really old cabins had the dovetail notch. Took a whole lot more skill than what we had, cause we were just using hand tools. There might have been one or two chainsaws amongst all of us, but for the most part we were all using hand tools." To fill in the spaces between the logs, they used "quarter rounds. So you would take a narrower log and split it into quarter pieces. Then it was like a puzzle. You would take all of these quarter pieces and try to find the right fit for the hole between the logs.” The quarter rounds were nailed in place, "and then on the outside, we would ... staple chicken wire up, and then we'd try to get the purest clay mud that we could, and then we'd throw that up against the chicken wire. And that’s how we chinked it.” Using clay for chinking, as Salstrom later discovered, was not an optimal material, as it deteriorated quickly and invited mud daubers and other insects. Once they realized that the chinking could crack, leaving "powdery red clay kind of filtering down in through the cracks" of the cabin, they switched to mortar for chinking. Salstrom's assessment of living in the cabin: it "was drafty, to say the least." 40

Cabins might have been drafty, but they afforded many in-migrants with cheap, sturdy housing that could be erected quickly. The act of building, and in some cases restoring, them, as

\footnotetext{
${ }^{39}$ Connie Abraham, interview with author, Flatwoods, WV, March 18, 2011.

${ }^{40}$ Jan Salstrom interview, 2008.
} 
with other homesteading activities, also left them with a sense of independence and freedom.

Thurlowe Scudder moved with his family to Floyd County in 1981 from Ohio. The day that they arrived to the community, he felt, was “'a nice day to declare our independence.”' Like Rutledge, he felt ambivalent about the phrase "back-to-the-land," because he believed that it suggested that he was trying to return to some romanticized agrarian past divorced of modern technology and circumstances. He argued instead that his interest in homesteading and preserving log structures combined elements of "both the traditional and modern.” Along with his wife and son, he lived in a log cabin that "doubles as living quarters," but he eventually planned to build a separate cabin for himself, his wife, and his mother. ${ }^{41}$

Although Scudder and other alter-natives dismissed notions of their activities as nostalgic, there were elements of romanticization inherent in the decisions that they made regarding their lifestyles in rural Appalachian communities. Many alter-natives were prompted to move to Appalachia based on highly developed illusions about what the region's society, culture, and environment could offer them in terms of a more authentic and grounded experience. ${ }^{42}$ This was evident in the widespread popularity of regional folk performers like Doc Watson and the booming attendance at mountain folk festivals through the late 1960s and 70s, as well as newcomers' expressed hope to learn all they could from regional neighbors who they considered to be independent and self-sufficient. Their decision to stop identifying with the dominant culture in which they were raised and to start emulating outsiders—in this case, white Appalachians and Native Americans—-was their first act of declaring autonomy against a corrupt and oppressive

\footnotetext{
${ }^{41}$ Wanda Combs, "Pilot Man 'Pioneering' with Varied Lifestyles,” Floyd Press, November 18, 1982.

${ }^{42}$ Patrick C. Jobes, author of a sociological study of aesthetic migration into the Northern Rockies, writes at length about the disillusionment that newcomers experienced because of the "inaccurate illusions" they had of the places to which they were moving. His research suggests that the greater the illusion, the less likely the in-migrant was to remain in the community long-term. See Patrick C. Jobes, Migrating Nearer to Heaven: The Illusions and Disillusions of Migrants to Scenic Places (Westport, Connecticut: Praeger Publishers, 2000).
} 
system. The physical spaces they created on the imagined fringes of society, argues Grace Elizabeth Hale, were the second. And “environmentalists,” she adds, “dropped living people altogether . . . and romanticized nature instead as a place uncorrupted and innocent, harmless and pure.”43

So the built environment became a physical manifestation of the process through which alter-natives expressed their identification with nature and the rural poor. But it is important to recognize that while the push for self-sufficiency was infused with nostalgia for an imagined past and illusions about rural residents and the environment, there were pragmatic and progressive undertones to the movement as well. Like Rutledge argues in his interview, and as movement thinkers like E.F. Schumacher contended at the time, in order to succeed on the land, one should borrow time-tested tools and technology from the past but also should not ignore modern advancements that would make life simpler and more sustainable. In his book on the Whole Earth Catalog, Andrew Kirk contends that the sprawling sourcebook so heavily used by homesteaders and other counterculturalists actually helped to develop a "pragmatic” strain of environmentalism that had not existed prior to 1969, when the first catalog was published. Rather than drawing a line between human activity and nature, as had generations of conservationists, and focusing solely on bureaucratic policies to mitigate the worst excesses of industry, the Whole Earth Catalog provided practical technological solutions that individuals could apply to their daily lives. Because so many homesteaders and communitarians in Appalachia and elsewhere read the Whole Earth Catalog, it is reasonable to assume that they were at least partially

\footnotetext{
${ }^{43}$ Grace Elizabeth Hale, A Nation of Outsiders: How the White Middle Class Fell in Love with Rebellion in Postwar America (New York: Oxford University Press, 2011), 6.
} 
responsible for disseminating some of those ideas to other rural residents equally concerned about energy shortages and inflation. ${ }^{44}$

In Appalachia, the embrace of the new "green” technology took many forms. There was no standard way in which people built or refurbished their cabins, outbuildings, water systems, or other amenities. But people improvised, sometimes using "how-to” articles from magazines like Whole Earth and sometimes relying on trial and error. In an advertisement for a commune seeking people in western North Carolina, Tom Schmidt cautioned readers, "any home would have to start from the resources immediately available in the local mountain community, the family, and the Whole Earth Catalog.” ${ }^{45}$ One of the first improvements that Lynn Stasick made to his land in Wetzel County, West Virginia, was rerouting a creek branch to the main creek in order to drain a field. He and his wife then proceeded to build their cabin out of lumber taken from a dilapidated barn on their land. The rest he obtained from a sawmill where he worked in exchange for the wood. But he also fashioned a gravity-fed water system, which was a common solution for alter-natives who needed access to running water.

I eventually put running water in. I built a-there were two converging ravines, about a hundred and fifty, maybe a hundred seventy five yards up above my house, up in the hollow — and I built a big stone cistern which would fill with water, and then I ran a pipe

\footnotetext{
${ }^{44}$ The form and function of the built environment on Appalachian homesteads and communes reflects the confluence of several different strains of thought about nature, antimodernism, and technology in the 1970s. Even as technology was celebrated in the postwar era, there was growing criticism of some of its excesses, particularly related to nuclear power. Added to that critique were influential thinkers like Rachel Carson and Barry Commoner, who joined with others questioning just how beneficial technology might be. Lewis Mumford in particular, who had early in his career celebrated technological advances, had grown critical of technology because of its ability to facilitate unprecedented capitalist growth and power. But perhaps most influential to the counterculture, which sought to reject the centralizing tendencies of science and government, was E.F. Schumacher, whose book Small is Beautiful articulated a new vision for "appropriate technology." Various strains of political activists, scientists, and counterculturalists contributed to the original definition, and there was little coherence in how it translated to action on the ground. But as Kirk summarizes, such technology should be "cheap, simple, and ecologically safe" as well as conducive to creating more "self-sufficient lifestyles and new social structures based on democratic control of innovation and communitarian anarchism.” See Andrew G. Kirk, Counterculture Green: The Whole Earth Catalog and American Environmentalism (Lawrence: University Press of Kansas, 2007), 26-31.

${ }^{45}$ Tom Schmidt, “Letter,” Communities, September 1972.
} 
down to the house and I took a water tank, a big old iron water tank, and put it up on a rack and painted it flat black, and it would sit all day. You'd have an outside shower at night with some warm water.

Stasick admitted that many of his ideas and innovations came from books or articles that had been publicized in the sprawling sourcebook. ${ }^{46}$

Access to water was crucial, and not always easy, for in-migrants. Some people had purchased land assuming that drilling a shallow well would provide an easy water source only to find that they had to drill much deeper than originally anticipated. Costs could double, and sometimes triple, as a result. The more thoughtful alter-natives who took great time and care in choosing their plots of land made sure they had easy access to springs, creeks, or rivers. Homesteaders celebrated the purity of water in Floyd. The pristine mountain streams that only flow out of the county—no water flows in from elsewhere-meant that water quality could more easily be protected by local laws and ordinances, once they were established. ${ }^{47}$

Some people had few qualms about using available resources if it meant that they could achieve independence. Some areas, particularly in West Virginia, were rich in fossil fuels, and homesteaders and communitarians who moved to those places took advantage of the available resources. A lucky few migrants to the Mountain State discovered that they had "free," or relatively easy, access to coal, oil, and natural gas, a welcome amenity for people seeking shelter in ice-cold cabins and corncribs. But attempts to tap into these resources did not always pan out, as Paul Salstrom discovered on his hunt for "free coal.” He, along with two other in-migrants, sought out a native named Mike who knew where to find old or abandoned mines. Mike, a

\footnotetext{
${ }^{46}$ Lynn Stasick, interview by author, Morgantown, WV, March 2, 2008.

${ }^{47}$ More will be said about alter-natives' attempts to protect the county’s water in Chapter Six. "Floydfest Grows Up,” Jambase, August 27, 2004: under “Floydfest Grows Up,”

http://www.jambase.com/Articles/5462/FLOYDFEST-GROWS-UP (accessed December 19, 2010).
} 
disaffected Vietnam Veteran, took them to three separate sites with dynamite in tow, but they never obtained access to coal. The veteran attributed their lack of success to either the rising prices of coal, which had led mineral owners to tighten access to their mines, or his adverse military record, which left him facing a chilly reception from community residents. ${ }^{48}$ Low-cost natural resources were sometimes advertised in movement literature. John Vivian recommended Appalachia to readers of Mother Earth News because "hill country land is cheap, water is plentiful, and there are many places where you can dig your own coal from surface seams that are too small for commercial mining."49 Jerry Brunetti, who co-founded a commune in Harrisville, West Virginia, indicated to potential members that they planned to build a "central community house offering a kitchen” with “a place for electrical appliances (hopefully generated by our own natural gas wells some day).”50

Independence or Imperialism? Ethical Considerations

The question of relying on coal, oil, or natural gas sometimes raised ethical dilemmas, particularly for the most environmentally-conscious homesteaders and communitarians. The acquisition of land could be equally troublesome. Many in-migrants, like Judy Strasser, were conflicted about land ownership and use. She cautioned that anyone who moved to rural areas without a high level of commitment to "achieve rural equality and rural independence” would be “no different” than a "British imperialist” or "Nelson Rockefeller cooling his heels and refreshing his spirit on the grounds of his four elegant country retreats." 51 Tony Norris "was not

\footnotetext{
${ }^{48}$ Paul Salstrom, "Son of Coal,” Green Revolution, November 1975.

49 John Vivian, “A New Year New Plans,” Mother Earth News, January / February, 1976: under "New Year, New Plans,” http://www.motherearthnews.com/modern-homesteading/practical-homesteading-zmaz76zhar.aspx (accessed December 19, 2011).

50 Jerry Brunetti, “Leatherbark Community Farm,” Communities, February 1973.

51 Judy Strasser, “The Land is No Escape,” Communities, December 1974.
} 
sure it was ethical to own land," so he refused to purchase a plot after moving to West Virginia from Heathcote. He only reluctantly agreed to support a land trust in Lincoln County that Paul Salstrom helped to initiate in 1975. In fact, that land trust was part of a statewide contract that was initiated in 1974 at a conference held on a Catholic Worker farm in the county. Mildred Loomis attended, as did Salstrom, members of the Peacemaker farm in Hacker Valley, West Virginia, and in-migrants from other counties. The land trust was one way that socially conscious alter-natives could implement their ideas about preserving the environment, particularly in a state that relied so heavily on natural resource extraction, and some, like Tony Norris, could reconcile their ambivalence toward landownership while still being able to engage in small-scale farming and homesteading. In a trust, land was "placed into collective trusthold in perpetuity.” It could "never be sold, rented, or used as a form of capital or wealth to make profit from the labor of others (as in tenant farming or wages unequal to the proportion of work done).” Chuck Matthei of the Peacemakers, a pacifist group extending back to the late 1940s, placed that organization's decision to form a land trust in the context of the plight of local farmers and the burgeoning tourist industry in the Hacker Valley. Farmers were destitute and ready to sell land to willing buyers, including tourists and second homeowners. He felt "it was not morally right to buy land from someone [a local farmer] who was hard pressed, in effect capitalizing on his predicament.” Several members of the Peacemakers believed "that land, like air and water, is not rightfully subject to ownership; that each of us has a natural right—a right to life—-to use the land we need to live and make a living, but not to abuse any land or to hold and limit the availability to others of land beyond our real needs." It was in that context that they decided to put the land in trust. Added to the sprawling, multi-county contract was a clause "stipulating that in the event of a 
threat to any of its holdings, especially . . . strip mining . . . all parties to the charter would 'meet to consider unified direct action against the threat, including nonviolent civil disobedience., ${ }^{52}$ Expressions of dissent against conventional notions of ownership, consumption, and control expressed themselves in other ways. The fear of the deterioration of control over one's own life_-and body_ - and the decline of a sense of community that was wrought by suburbanization, bureaucracy, and unsavory technological developments prompted homesteaders and communitarians to center their lives on the home and the sub-communities that they built in Appalachia. The home became the symbolic and literal center of birth, growth, and death for alter-natives. Many women sought to remove themselves from all reaches of the "technocracy," including the medical establishment. Asserting one’s independence meant regaining control over the body and decisions regarding physical health and well-being. Many alter-native women opted to have childbirth at home, and several proceeded to become certified nurse midwives later in life. "In our community,” recalls Joanie Goldsmith, “and other communities, home birth was the way to go ... That was just to have the experience. When you have a baby, the way we felt was we wanted to know what that was about. We wanted to feel it. We didn't want it to be a medical procedure." ${ }^{53}$ For Katherine Chantal, homebirth was just another expression of the desire to assert autonomy over her body as well as her family. An herbalist, she considered herself to be her family's primary health care practitioner and only used medical professionals as a last resort. ${ }^{54}$ Some, like Susan Meade and Jan Salstrom, even became involved with statewide movements to create standards for midwifery and to push for either new legalization or the

\footnotetext{
52 Tony Norris, interview by author, Morgantown, WV, May 19, 2011; Paul Salstrom, "From Rugged Individualism to a Community Land Trust,” Green Revolution, January 1975; “Trekkin with Chuck Matthei of Peacemaker through West Virginia,” Communitas, September 1972; “What is Peacemakers?” Green Revolution, September 1976.

53 Joanie Goldsmith, interview by author, June 24, 2011.

${ }^{54}$ Katherine Chantal, interview by author, Floyd, Virginia, August 3, 2011.
} 
reformation of existing laws that prohibited midwives from accepting payment for their services. $^{55}$

Homeschooling as well became a popular educational option for alter-natives, particularly for those who believed, as did Rob Yard, that public “'education now has as its purpose to provide those in power with satisfactory puppets to do their work so the masters can remain wealthy.'” Rejection of conventional public education systems became yet another expression of political dissent and alter-natives' pervasive fear that their children would become “indoctrinated” and groomed for mindless, uncreative work. Sometimes this took the form of “unschooling,” an educational philosophy that Ed Gralla applied to his own children. It maintains that children decide their own curriculum; they follow their own interests rather than being fed information they are expected to know. ${ }^{56}$ In other cases, parents banded together to found new schools that encouraged socialization yet still allowed parents to have significant control over their children’s educations. Many newcomers also opted to homeschool their children or established new schools that they felt would better foster independence and creativity among their children.

Overcoming Isolation: Building Alternative Communities

Fairly quickly after arriving, homesteaders sought to recruit other like-minded people to their communities. In 1977 Patricia Beaver observed that countercultural migrants to western North Carolina often hosted guests, friends who maintained a "shared vision of a counterculture community in the mountains.” The homesteaders she documented actively recruited other like-

\footnotetext{
${ }^{55}$ Susan Meade, interview by author, Floyd, Virginia, July 20, 2011; Jan Salstrom, interview, 2012.

56 Jacque Wilson, “Unschoolers Learn What They Want, When They Want,” CNN, August 3, 2011, under “Unschooling,” http://www.cnn.com/2011/US/08/03/unschooling.sudbury.education/index.html (accessed June 3, 2012).
} 
minded individuals who sought to reject conventional lifestyles in favor of self-sufficiency. Part of this recruitment was born of the alter-natives' altruistic desire for social reform. To them, the more people to model a less consumption-oriented, more sustainable way of life for the rest of the world, the better. But it was also a normal response to loneliness. One of the homesteaders featured in her book, "Linda," frequently invited friends to visit her and her husband "Larry.” She sought both "artistic outlets" in social networks that existed outside of the immediate community and "people with whom to share her ideas and perspectives."57

Visits to the couples' home sometimes translated into more people moving to the area. "They were always looking for others who could buy and move" to the county, observes Beaver. It was in these visits that the process of building the countercultural community began. New arrivals would typically locate land through "an established realtor, a local country store, a local land entrepreneur, or a friend's connections in the community." They typically knew at least one other established countercultural family, so they would quickly integrate into the alternative subcommunity. Those who did not know anybody "were occasionally introduced through a local health-food store, restaurant, or craft shop” and were invited to participate in community events. During their transition between old and new locations, they would often camp out on established residents' land or stay in their homes. The assimilation process for new arrivals was made smoother by the fact that "the rhetoric and lifestyle were so extensively shared that formal introductions and long periods of getting acquainted were seldom needed before close helping and sharing relationships were established." 58

\footnotetext{
${ }^{57}$ Although some homesteaders moved to the mountains seeking social isolation, the reality was that it became a major factor in some alter-natives' eventual decision to leave.

${ }^{58}$ Because of the high prices of land in western North Carolina, transitions from old communities to new could sometimes take longer than in cheaper areas like Floyd County, Virginia, and Lincoln County, West Virginia. People would sometimes keep jobs in surrounding lowlands, like Charlotte, to be able to pay for their land and buildings. In some ways, they became temporary weekenders who resembled the wealthier second homeowners or seasonal residents who were likewise responsible for driving up the costs of land prices in the region. Patricia D.
} 
The types of assimilation into the countercultural community in western North Carolina that Beaver describes were not exclusive to that area. The story repeats itself in Floyd, Lincoln, and other Appalachian counties. Would-be in-migrants heard about a location through friends or acquaintances, paid visits to the area, found the existing alternative community to be warm and welcoming, and enlisted their assistance in finding property or a place to live. Alternative subcommunities emerged as homesteaders and communitarians worked, lived, ate, and played together. They helped each other to realize their vision of the good life based on simplicity and self-sufficiency by organizing work parties, food cooperatives, and social events.

Food cooperatives, which were founded in dozens of Appalachian communities during the 1970s, served as important avenues for obtaining products not typically available in rural Appalachia. Perhaps more importantly, they provided alter-natives with the opportunity to connect with like-minded individuals in their own communities and, occasionally, in other areas of Appalachia. The most basic idea behind the food cooperatives was to allow members to purchase bulk foods — typically grains, beans, flour, and other dry products—at discounted rates with profits being returned to members. But cooperatives were about much more than obtaining costly products at a discount. They were an extension, asserts journalist Craig Cox, of a countercultural vision to create a "self-sufficient network of cooperatively owned enterprises serving the common good.” The tofu, quinoa, and wheat germ were a reflection of middle-class tastes and preferences for a high quality of life, but those products also symbolized a larger push to reform society by creating “cooperative commonwealths,” networks of alternative enterprises-from organic farms to communes to "hippie lawyers" - that were "connected by a spiritual, cultural, and economic fabric woven from shared experiences and beliefs." He reveals

Beaver, Rural Community in the Appalachian South (1986; repr., Prospect Heights, Illinois: Waveland Press, 1992), 125-126. 
that entire cooperative networks were established in regions across the country that could serve any variety of needs of people pushing for independence and self-sufficiency. ${ }^{59}$

At food co-op meetings in Appalachia, families typically brought dishes to share and ate, drank, and conducted their meeting to order food products and supplies. But the co-operatives also belonged to larger, regional organizations. The Appalantic Federation of Cooperatives serviced smaller co-ops in North Carolina, Virginia, and parts of West Virginia, including Floyd's co-op and the New River Co-op in Hinton, West Virginia. ${ }^{60}$ The Federation of Ohio River Cooperatives, or FORC, provided food for communities in Lincoln, Roane, Calhoun, and other West Virginia counties, as well as communities in Ohio. Cooperatives connected inmigrants in rural communities to other like-minded individuals in the region and provided them with opportunities to discuss larger issues related to nutrition, food consumption and production, and economic inequality. These organizations wrestled with questions surrounding access to nutritional foods for "low-income people in the inner-cities and rural areas," and whether or not to “include more conventional grocery items" rather than just "natural” foods. ${ }^{61}$

In Floyd, roughly twenty-seven newcomers belonged to a cooperative before it found a home in a three-story gristmill on Route 720, just outside of the downtown area. It opened in early 1977 and offered items such as “grains, beans, and flours.” By 1981, when Roanoker Magazine published a feature article on the alternative community in Floyd, it had evolved into a "headquarters” for the new arrivals. As manager Lynne Ray said, it became “"a sort of forum for people who have moved here from outside. It serves a definite social function." "62 People who were looking for access into Floyd's alternative community_either for land or services—would

\footnotetext{
${ }^{59}$ Craig Cox, Storefront Revolution: Food Co-ops and the Counterculture (New Brunswick, NJ: Rutgers University Press, 1994), 2-5.

60 “Co-op Manager Attends Conference,” Floyd Press, July 30, 1981.

61 “Co-op Manager Attends Conference,” Floyd Press, July 30, 1981.

${ }^{62}$ Seth Williamson, “The New Pilgrims of Floyd County,” The Roanoker, April 1981.
} 
often visit the co-op to gather information. "Karen Martin,” who lived in Christiansburg before moving to Floyd, began searching for a midwife on behalf of a friend in the late 1970s.

Following the lead of some "rumors" about midwives who practiced in Floyd, she visited the Mill Co-op to try to obtain names of women who could attend the birth. "Nobody" provided midwives’ names “because I was a stranger,” and Virginia had made it illegal in 1976 for women to attend homebirths without a license in nurse midwifery. "There were midwives here but they would get in trouble," she recalled. But in spite of her failure to locate a midwife, she found at the co-op a community of "like-minded" people such as she felt were relatively absent from Christiansburg. She and her husband eventually relocated to Floyd County. ${ }^{63}$

The Mud River Pantry in Lincoln County likewise served as an important social outlet and free space for new arrivals in that area. ${ }^{64}$ The "Spooner family" founded the co-op; they had moved to Lincoln from Kent, Ohio, where they had founded a separate cooperative. The Pantry began in 1973 when the Spooners' attempt to deliver natural foods to newcomers in Lincoln got stuck in the mud. "It started off in a van stuck in the head of a hollow full of food from Kent," remembered Jim Chojnacki. "Then it came over to our farm and we put it in the back of our house for a while." It later "got a place of its own over at the mouth of Middle Creek.” That, he added, was in the "heyday" of the back-to-the-land movement in Lincoln County. With a grant

\footnotetext{
63 "Karen Martin,” interview by author, Floyd, Virginia, September 26, 2011; See also, Christa Craven, Pushing For Midwives: Homebirth Mothers and the Reproductive Rights Movement (Philadelphia: Temple University Press, 2010), 13.

${ }^{64}$ Scholars such as Sara Evans, Harry Boyte, Richard Couto, and Stephen Fisher understand "free spaces" as places within communities that provide citizens with the opportunity to develop greater self-awareness and a sense of collective identity, solidarity, and civic purpose. This new awareness has the potential to provide participants with strength and conviction in confronting class-based, racial, or gender inequalities. But, as Stephen Fisher and another scholar, Benjamin Barber acknowledge, there is the potential for these institutions to reinforce existing antidemocratic impulses. Although this topic warrants further exploration, food co-operatives in Appalachia likely provided countercultural newcomers with an increased sense of collective identity and purpose in fulfilling their self-sufficient mission. There is also evidence that the co-ops provided free space for people to engage in planning in regards to staging protests against perceived threats to their way of life, environmental or otherwise. Still, food cooperatives also reinforced a middle-class, urban aesthetic by not offering food products that would have appealed to the local population, the exclusion of meat being one example. Couto, 46-51.
} 
from the West Virginia Catholic Diocese, the co-op found a permanent home in an old farmhouse. As Paul Salstrom reported through the Green Revolution in 1976, both newcomers and old timers began frequenting the store. "A network of sharing and trust ... evolved" in the community because of the co-op. "Especially popular at the monthly business meetings of the co-op" was "the communal meal followed by lots and lots of music." ${ }^{35}$ Not only was the Pantry important for social gatherings; it also became an important location for the discussion of key issues in the community, including how to prevent surface mining from taking place in the county. "There [were] priests here doing some Catholic work and they were active with the strip mine issue,” says Chojnacki. "Yeah, the Pantry was the meeting place of the environmental resistance to the coal [interests]." 66

Work parties likewise fostered a sense of community among newcomers. Cabin raisings are one of the most commonly cited activities in which homesteaders and communitarians participated during the early years of the movement. Constructing the log structures was not simply an act of asserting independence, as described by Thurlow Scudder; it was additionally an important community-building activity for newcomers (as well as natives, which will be examined in the next chapter). Jan Salstrom so enjoyed them that she hiked ten miles across Lincoln County to attend one with a man who later became her husband. John Salstrom had heard that she liked to attend cabin raisings, so he visited her teepee at the head of a hollow to see if she would be willing to accompany him. ${ }^{67}$

In the words of Joanie Goldsmith, alter-natives might have been "busy, busy, busy all the time,” but they still created plenty of opportunities for play, and their recreation served an important role in strengthening social networks and interdependent relationships among the new

\footnotetext{
${ }^{65}$ Paul Salstrom, “The Pantry,” Green Revolution, September 1976.

${ }^{66}$ Jim Chojnacki, interview by author, Myra, West Virginia, July 2, 2011.

${ }^{67}$ Jan Salstrom, interview, 2011.
} 
arrivals. The Goldsmiths' cohort periodically visited their friends who "had heat and they had a stereo and they had a TV." They trekked to their home "once every ten days or so" to shower and to "listen to great music and get high and eat good food and all that stuff that we just didn't [normally] do” while on the farm. Potlucks became a staple of the countercultural social calendar, as did solstices, weddings, harvest festivals, and other activities.

When asked about social activities in Floyd, Will Bason remembered potlucks as having been one way of connecting and socializing with other countercultural residents. But the big anchors of the community were solstice gatherings and the annual Halloween party, which was held at a skating rink that had once housed a bar with a reputation for drunken debauchery. By the 1970s, it had become a skating rink that the alter-natives would rent on Halloween: "There was this annual Halloween roller skating party that was one of the high points of the social calendar for quite some time," said Bason. "And then there were the solstice gatherings, summer solstice gatherings. Those two things." But the solstice gatherings became "too big and too crazy," he added, and the host commune, Riverflow, located in the northeastern portion of the county, decided ultimately that it did not want to sponsor them any longer. ${ }^{68}$

Bason lamented the loss of the solstice gatherings at Riverflow because they served as an important "touchstone" for the countercultural community in Floyd. Although Beaver makes no mention of communes in her North Carolina study, they became central to the development of the in-migrant population both in terms of recruitment of additional residents and of identity and cohesion for a number of Appalachian communities. While most communes were relatively short-lived, they served as an important medium for promoting the self-sufficient ideal, for recruiting countercultural in-migrants, and for anchoring burgeoning alternative subcommunities. A few independent homesteaders dismissed the commune movement as separate

\footnotetext{
${ }^{68}$ Will Bason, interview by author, Floyd, Virginia, September 25, 2011.
} 
and distinct from the back-to-the-land movement, but in reality, there was a significant degree of overlap between the two. They were not mutually exclusive. ${ }^{69}$ Some people, including Joanie Goldsmith, had already lived in community prior to moving back to the land and ultimately decided that nuclear families were best suited to their needs. Others, like Patricia Harman, resided in Appalachian communes temporarily, leaving once they had children or found their own plots of land, or after the rest of the membership had drifted away. ${ }^{70}$ Still, a number of original in-migrants preferred communal living and often adjusted the communes to fit their individual needs for privacy as they aged. Many of the Floyd alter-natives reside in "intentional communities" to this day.

Advertisements in Communities magazine from the 1970s reveal some of the ways in which people connected to other in-migrants and hoped to achieve self-sufficiency by living in community. Arnie Freiman and Ileane Jones announced plans to create a commune in Roane County, West Virginia, that would focus on children and would create a "totally self-sufficient farm based on small farming and cooperative businesses.” They also hoped that their farm would form the nucleus of an alternative community in their area. ${ }^{71}$ Lydia, who wrote to Communities to recruit membership for Iris Mountain Community in Unger, West Virginia, spoke of her commune's focus on caring for children, personal responsibility, and green living. "The little people are top priority for time," she warned. "Equally important is the emphasis on individual responsibility for behavior and commitment to the common ... whatever, with freedom to get

\footnotetext{
${ }^{69}$ In addition, there seems to be some confusion regarding what exactly constitutes a commune. Timothy Miller's study of 1960s communes offers some guidelines that inform this study. Communes are composed of people who interact with each other on a regular basis and encompass more than just nuclear family, live in geographic proximity to each other, share "a sense of common purpose" and alienation from mainstream society, provide some level of economic support for membership, and actually existed (as opposed to thousands of others that were proposed but never materialized). Timothy Miller, The 60s Communes: Hippies and Beyond (Syracuse, NY: Syracuse University Press, 1999), xxiii-xxiv.

${ }^{70}$ See Patricia Harman, Arms Wide Open: A Midwife's Journey (Boston, MA: Beacon Press, 2011).

${ }^{71}$ Arnie Freiman and Ileane Jones, “Letter,” Communities, October / November 1973.
} 
one's head, etc. together.” Ultimately, the community’s idea of the “'good life”” meant "organic gardening, wholesale buying, simplicity of lifestyle, and conservation of natural resources and energy."72 The Free Growth commune, situated in Monroe County, West Virginia, acknowledged that it had struggled to work out "a lot of the emotional problems of communal living,” but through the process had developed "communal goals with flexibility and recognition of continual change." They hoped to find "self-actualized people who wish to change their lives by developing non-role oriented, non-exploitative communal lifestyles" and who could become participants in a life of "joy, love, unity with man and nature, sensual fulfillment, sharing, selfsufficiency, cooperation, and ... freedom." ${ }^{, 73}$ Four adults who hoped to start a commune in the Potomac Highlands of West Virginia specifically sought members skilled in organic farming and craft production. Their proposed community would draw from a variety of religious traditions including Christian, eastern, and Native American ones, and would minister to the surrounding community. "For the good life, we believe men should live with the threatened end of civilization. We want to relate to mankind and nature according to the Creator's Will by trying to start a love-motivated, non-exploitative society." 74

In Floyd, communes such as Riverflow and Travianna became key avenues through which people seeking alternative lifestyles were introduced to other alter-natives. Floyd alternative Ed Gralla had spent a great deal of time and energy evaluating different communities along the East Coast for their suitability for farming, low taxes, a sense of culture, and proximity to centers of higher education. He had initially considered Asheville, North Carolina, as a possibility, but he found that area to have been "less welcoming” than Roanoke, Virginia. While visiting a health food store in the Star City of the South, he heard about Floyd and paid a visit to

\footnotetext{
${ }^{72}$ Lydia, "Iris Mountain,” Communities 2, February 1973, 53.

73 "Free Growth," Communities 3, 1973, 57.

${ }^{74}$ Dick Baker and Ross Anderson, “Letter," Communities 4, December / January 1974, 55.
} 
a local farm. He found land that day and soon after attended a newcomer social gathering at Riverflow. He left with the sense that Floyd could offer a "natural progression from" the spirit of community at the Woodstock festival. ${ }^{75}$ Melody Cochran, who was the daughter of a man who first visited and then settled in Floyd, ahd spent her childhood summers in the county. She recalled in vivid detail the warm, inviting atmosphere that the Travianna's matriarch, Ruth Bason, "fostered" for visitors and permanent residents. Even at a young age, Cochran observed a "sense of community there and openness." Ruth made Travianna available "to anybody who wanted to come" and, in Melody's mind, made it even more welcoming "than a lot of people normally would [have been] ... that were coming to homestead. [Bason] was kind of like, 'Well, we've got plenty of land here. Come.'” The end result was a steady stream of young drifters, artists, and musicians who passed through the commune in search of themselves, in search of land, and in search of refuge. Many “just stayed for visits" while other "people stayed for years." 76

“No Way a Little City Gal Could Actually Do That”: Problems with Self-Sufficiency

As Eleanor Agnew observed in her book on the back-to-the-land movement, there were problems with the self-sufficient vision that transcended both communes and independent homesteads. The hardships inherent in simple living ultimately undermined hopes for any sweeping social reform that might have come out of the movement. (It did, however, have its small successes and prompted the creation of more eco-conscious consumerism, which will be discussed in subsequent chapters). Communes in particular were easy targets for politicians and other people critical of the counterculture and its emphasis on collectivism, personal liberty, and

\footnotetext{
${ }^{75}$ Ed Gralla, interview by author, Floyd, Virginia, August 4, 2011.

${ }^{76}$ Melody Cochran, interview by author, Floyd, Virginia, August 3, 2011.
} 
hedonism. For many communitarians, naïveté sometimes blended with immaturity to thwart plans for self-sufficiency. Communal matriarch Ruth Bason's younger son, A’Court, who came of age while living at Travianna, made some interesting observations about that community's dynamics, observations that reflected a mixture of philosophical rationality and the unreconciled frustrations of youth. Because it served as a (typically temporary) home to such a wide variety of people, "there was no real structure" to the community. Residents attempted self-sufficiency by gardening, keeping livestock, churning butter and making cheese, but there was a general problem with a "bunch of numbskull students and crazy spiritualists" who had assumed little responsibility for anything before in their lives. "These were like 19, 20, 23 year olds,” Bason recalls. "They've never been in a real marriage or relationship. Still selfish ... It was pretty rough. It was difficult. Sometimes it'd be like eighteen people living in that one farmhouse all winter.” Providing an example of a typical conversation that communitarians once had about their responsibilities, he said, “'It's your turn to milk the cow!' 'Oh no! ... I'm not milking the cow.",77

Bason's experiences were not unique; social commentators at the time and scholars since have speculated that one of the main reasons that the commune movement of the 1960s failed, with a few important exceptions, was because of immaturity and the difficulty that people who had been raised in nuclear family households had adapting to communal living arrangements. Several people writing in the 1970s knew that the commune movement was troubled. One person wrote to the Last Whole Earth Catalog to vent about conditions at The Farm in Tennessee, which is outside of this study's geographical area but nonetheless influenced a number of alter-natives who eventually migrated to Appalachia. The author spoke of a "pigs-in-a-trough" vibe that, in

\footnotetext{
${ }^{77}$ A’Court Bason, interview with author, August 1, 2011.
} 
his or her opinion, forecast the community’s decay. “If you don’t eat fast, your sty-mate will get more than you do. And if you don't avoid chores, you will be doing more work than your sty mate ... Because there is no sense of community, each person is 'right' in grabbing the goodies and avoiding the work." ${ }^{78}$ Mildred Loomis speculated that nuclear family-based homesteads were more successful than communes because of the need for privacy. "Homesteading decentralists," she observed, "are not just drop-outs escaping to a doubtful hedonism. They are not fleeing from memories they reject and from a future they dread. They choose their life-style in reference to what they call 'norms of living' -i.e., values, standards and actions through which they can best fulfill their human potentials.” They could best realize their potentials, she believed, by living independently. ${ }^{79}$ Historian David Shi notes that because of "their disgust for the modern work ethic," young communitarians "tended to exchange the materialist hedonism of the consumer culture for the sexual and sensory hedonism of the counter culture.” The result, he contends, was that they often produced "more babies than bread.",80

Scholarly and popular criticisms of communal living should not diminish the painful realities of transitioning away from communal arrangements to independent homesteading. Patricia Harman, who chronicled her life in community and her evolution as a midwife, captured the emotional turmoil that some people experienced once they realized that their communal family was disintegrating. Several years after moving to Roane County, West Virginia, Harman watched as her community slowly atrophied. One couple or individual after another decided to leave. One of Patricia's friends explained that she had grown “'tired of grubbing in the earth ... of always being cold or hot or dirty."” Patricia’s partner Tom felt optimistic about the change,

\footnotetext{
78 “All Asshole Farm Expose,” The Last Whole Earth Catalog, 1971, 181.

${ }^{79}$ Mildred Loomis, "Decentralists Go Ahead and Live,” reprinted in Communitas 2, September 1972, 45.

${ }^{80}$ David Shi, The Simple Life: Plain Living and High Thinking in American Culture (Athens: University of Georgia Press, 1985), 258.
} 
but she failed "to see anything positive about the dissolution of our commune." It was a "slow landslide” and she reluctantly and bitterly accepted that there was "no way to stop the erosion." Dissolution was the eventual outcome of a vast majority of sixties- and seventies-era communes both in Appalachia and across the United States. Still, some people remained in communal living situations. They continued to live in either communes or the more contemporary "intentional communities," organized "neighborhoods" that allowed members a greater degree of independence while still enjoying a shared sense of purpose and community. In fact, the Floyd County Museletter, the alternative community’s newsletter that had originally been established as a forum for their independent school, continued to publish articles and commentary exploring the benefits of living in community throughout the 1980s and 1990s.

Illusions about what the self-sufficient lifestyle could offer in terms of personal satisfaction and growth were common among in-migrants, and they ultimately spelled the movement's demise on a large scale, although there were many holdouts. By and large, the 1970s-era back-to-the-land movement had peaked at mid-decade and tapered off by the mid$1980 \mathrm{~s}^{82}$ Vivid descriptions of the wonders of living close to nature and finding purpose and meaning in such mundane, daily tasks as cutting firewood or weeding that were presented in movement literature did little to prepare ex-urbanites for the hardships of rural life. Agnew believes that the movement failed once homesteaders realized that the lack of money, healthcare, leisure time, and intellectual stimulation in rural areas might not be worth the peace and quiet of country life. Many homesteaders began to desire the incomes and socialization that only urban areas offered. ${ }^{83}$ Movement adherents who had migrated based on popular notions about

\footnotetext{
${ }^{81}$ Patricia Harman, Arms Wide Open: A Midwife’s Journey (Boston: Beacon Press, 2011), 164.

${ }^{82}$ Jacob, 3.

${ }^{83}$ See Eleanor Agnew, Back From the Land: How Young Americans Went to Nature in the 1970s, and Why They Came Back (Chicago: Ivan R. Dee, 2004).
} 
mountaineers' independence and self-sufficiency perpetuated by movement literature quickly faced the economic, social, and political realities of rural areas. Building countercultural communities helped to mitigate the hardships to some degree, but even social institutions often failed to bolster a sustainable, enduring movement in Appalachia.

So what happened? Without completely rehashing the lively declensionist narrative offered in Agnew's book that points to lack of cash, harsh realities of rural life, children, isolation, and a host of other problems that induced most homesteaders to either migrate away from their farms or adapt by adding modern amenities, it is important to touch on a few of the problems that arose in Appalachia that both support and add new region-specific insights to her findings. Lawrence Goldsmith provides a perfect example of the types of general problems that regional homesteaders faced. He decided to move to the state after attending a folk festival in Pipestem, West Virginia, and contacting the United Farm Agency, which informed him that the southwestern corner of West Virginia offered the warmest climate and cheapest land in the midAtlantic. ${ }^{84}$ Although Goldsmith and his wife Joanie had only been in Lincoln County for a year, he conveyed in an article to the Green Revolution the difficulties that they had faced as homesteaders. They had gone in debt to purchase a 140-acre farm and planned to pay it back by selling organic potatoes and tomatoes in East Coast cities. Having been "too broke" to travel to those markets, they were "forced to sell tomatoes" locally at much lower prices. To survive, he and his wife went on welfare for four months until he took a temporary job at the welfare office. The position was extended, but he felt he was "going mad for the lack of time to do things" on his farm. But in order to purchase "seed and feed and all that other stuff," he needed income. The

\footnotetext{
${ }^{84}$ Lawrence Goldsmith, "How to buy Land,” Green Revolution, June 1970.
} 
stress of the situation affected his marriage; he reported that his wife had moved out and was building "her own house on the farm." 85

Financial demands that ultimately forced people to spend time away from homesteads or communes surfaced as the dominant trend behind the decline of the back-to-the-land movement. Going without health insurance or enough savings to cover potential accidents was an enormous risk. As Agnew observed, rural residents had a thirty to forty percent greater chance of accidental “disability and death” than city dwellers. The risk may have been even higher for homesteaders who had little clue of how to operate machinery or work with livestock. ${ }^{86}$ After injuring his hip, Garry Biggers realized that his simple life could not continue without a much greater income than he and his wife received from their nine-to-five jobs:

If we had had a steady income from, say, a trust fund or something like that, we'd still be there. There's no doubt in my mind, because we wouldn't have felt the necessity to have a business. But we just weren’t making enough money by working for somebody else. But if we'd have had, I don’t know, access to maybe eight thousand, ten thousand dollars a month, we'd have never had to leave there. We'd still be there. And it would have been a lot of fun. ${ }^{87}$

This was not for lack of trying. Homesteaders and communitarians came up with a host of ways to make money and financially support their farms. One means of financial support came from bartering. Earl M. Clough discussed this form of trade in Mother Earth News: "I was offered a Tri-Sport with its motor taken apart, in lieu of money owed to me. I carried it home on

\footnotetext{
${ }^{85}$ Lawrence Goldsmith, “Comfortin’ news from our WVA family,” Green Revolution, August 1972.

${ }^{86}$ Agnew, 160.

${ }^{87}$ Garry Biggers, interview with the author, Black Mountain, North Carolina, June 12, 2008.
} 
the top of my station wagon, a neighborhood boy put it back together, and I traded it for a ninefoot patio door." He also traded some walnut logs for labor. "Well, that's the way we do things here in West Virginia,” he explained, “and, until I started reading Mother, I'd never even thought of it as barter!” ${ }^{88}$ But bartering could only provide so much support for a farm. Some back-tothe-landers found themselves having to rely on food stamps to survive. Joanie Goldsmith and other ex-Heathcote in-migrants "had food stamps on and off depending on who worked and who didn't.” Some, including her husband and Tony Norris's wife Sue, even went to work for the welfare office. ${ }^{89}$ Others patched together odd jobs to make ends meet. During his tenure on the land, Lynn Stasick played music in bars, taught guitar lessons through a continuing education program at a local school, cut lumber at a sawmill, and cleaned for a local gas station. His friend Richard DiPretoro went into the mines and later became a pilot. ${ }^{90}$ Karl Hess and his wife relied solely upon her work as a freelance editor because in 1968 Hess had stopped paying income taxes. And former VISTA volunteer Ric MacDowell held positions as a county extension agent, a teacher, a director for an alternative wastewater project, and an amateur photographer. ${ }^{91}$

Small craft businesses became one solution to the problem of finding work that did not require alter-natives to abandon the home. Judson Jerome’s Fulton County, Pennsylvania, commune faced serious economic problems in 1976. The produce from their organic garden was not nearly enough to support the commune's nine members, and they were badly in need of “shop machinery, running vehicles, and, alas, A\&P groceries." They had to sacrifice some of

\footnotetext{
${ }^{88}$ Earl M. Clough, “\$uccessful \$waps,” Mother Earth News, March/April 1977, under “Earl Clough,” http://www.motherearthnews.com/Modern-Homesteading/1977-03-01/Successful-Swaps.aspx (accessed April 14, 2008).

${ }^{89}$ Goldsmith interview.

${ }^{90}$ Stasick interview.

${ }^{91}$ Karl Hess, “The Plowboy Interview: Karl Hess,” Mother Earth News, January/February 1976: under "Karl Hess," http://www.motherearthnews.com/Green-Homes/1976-01-01/The-Plowboy-Interview-Karl-Hess.aspx (accessed April 14, 2008); Ric MacDowell, interview by author, Hamlin, West Virginia, June 30, 2008.
} 
their self-sufficient ideals for the opportunity to earn much needed cash. "Indeed," he wrote, "in our formative years (which still continue), the practical demands of survival do take precedence over those of our various ideals and visions. Though our way of life was relatively simple, there was no way we could continue at all without some cash income.” The membership thus began making handcrafted "Hollolog Planters" to sell. ${ }^{92}$ They quickly found, however, that producing crafts for a local market was nearly impossible, for most native Appalachians could typically not afford such luxuries. Artistic alter-natives found that they had to join craft circuits and travel extensively to other cities and regions in order to make a profit. Maureen Hearn told the Floyd Press that when she "thought about having my own business ... I'm going to have more time for myself, for my land. I'll be able to really live the good life, and not be working this forty hour week, nine-to-five thing.” As it happened, she started putting in much more time to produce baskets. "Well,” she added, "I work eighty hours a week! And if I’m not working and making a basket, I'm feeling guilty and feeling like I should be making a basket.” She confessed that the craft show cycle was "killing" her because it demanded that she attend roughly one show per month. ${ }^{93}$

Children inevitably took time away from homesteading activities, changed to some degree the gender dynamics among alter-natives, and created the additional demand for income. As Ric MacDowell keenly observed, "It was one thing to struggle and eke out a living and not have running water or electricity when it was just the two of you, but when you had babies, it just altered stuff.” Caring for children was laborious; caring for children when you had to haul buckets of water in from a well, heat the water, and hand wash dirty diapers and clothing was another situation entirely. And when those children became teenagers, they typically wanted to

\footnotetext{
${ }^{92}$ Jud Jerome, “Downhill Farm and the School,” Green Revolution, December 1976, 11-12.

${ }^{93}$ Marysu Telsch, "Basket maker turns craft into profit,” Floyd Press, May 16, 1985.
} 
assimilate with their peers. MacDowell remembered a conversation with one woman who was upset because her daughter came home crying when her classmates discovered that she used an outhouse. Enjoying the same material comforts as mainstream America thus became a much bigger factor when children were introduced to the homestead. ${ }^{94}$

The intensity of farm labor drove some people away from homesteading. Many people, excepting perhaps Rutledge and a few others who had been raised on farms, were quite simply ill-prepared to handle the high physical demand. Despite the joys that may have come from living close to nature, observing the seasons, and digging in the earth, life on a subsistence farm was difficult, particularly for those ex-urbanites who had little to no previous farming experience. Naiveté about rural and agricultural life was a major problem for newcomers hoping to become self-sufficient. ${ }^{95}$ Letters to the editor of the Floyd Press revealed just how little homesteaders knew about farming and rural life. In June of 1977, Richard Creasy reported to readers that his first year in Floyd County, or more precisely, the community of Check, had been wonderful. He confessed that he had arrived to the county from the city "not knowing a hoe from a hog,” so he was most grateful to have landed in a place where people were willing to lend a hand. ${ }^{96}$ Another newcomer to Floyd, Bobbye Langston, was just as unfamiliar with country life. While still living in Richmond, Virginia, she discovered during a visit to a farm that her children believed that chocolate milk came from brown cows. Her own understanding of farm life was not much better. After arriving to Floyd in the spring of 1978, she planted a garden, and in the late summer she discovered "some dead looking things" that had surfaced in it. "I wasn't quite sure what they were,” she admitted. “It didn’t take that long for someone to tell me they were

\footnotetext{
${ }^{94}$ MacDowell interview.

${ }^{95}$ Jobes, 18.

${ }^{96}$ Mr. and Mrs. Richard Creasy, “Letter to the editor,” Floyd Press, June 9, 1977.
} 
potatoes!” Like Creasy, she was thankful to have found people in her community who took the time to help her develop gardening skills. ${ }^{97}$

A general lack of knowledge about self-sufficiency limited the duration of the movement and constrained its ability to prompt widespread social change. The notion of self-sufficiencythe core value of the movement and the motive that propelled so many people to Appalachia and elsewhere—was flawed. For certain, some homesteaders and communitarians fervently believed that they could achieve the goal. Judy Williams was one such person. She was no baby boomer; she was of retirement age when she became interested in homesteading. She convinced her husband, who had been raised in near poverty on a "hardscrabble farm" in east Tennessee (he had a "path to a potty," she asserted), that they should retire to a farm in Calhoun County, West Virginia. She, like many others, wanted to "grow [their] own food and live off the land." She and her husband had "sixty acres of woodlands and a wood stove" and "cut that wood by hand with an ax and a saw.” They also raised pigs and grew a garden. ${ }^{98}$ Her husband initially decided that if they were going to homestead, then they would do everything as primitively as possible. "We did everything by hand,” she claimed. "I guess maybe he was trying to help me see that going backto-the-land is hard work.” Horses may have worked for Jason Rutledge’s agrarian vision, perhaps because he recognized the need to incorporate traditional farming methods with modern technology, like plows, when necessary, but not everybody had such success, including Williams. ${ }^{99}$ She and her husband tried plowing with horses, but over time they realized that "on that hard clay hillside, there was no way a little city gal could actually do that.” Like others, they eventually decided to ease the lifestyle by adding power tools and forgoing the horses. And they

\footnotetext{
${ }^{97}$ Roberta (Bobbye) Langston, “Our First Winter in Floyd,” Floyd Press, May 10, 1979.

98 Judy Williams, interview by author, Morgantown, WV, January 14, 2011.

99 Jake Page, “The Suffolk Punch,” Mother Earth News, July/August 1987: under “Jason Rutledge,” http://www.motherearthnews.com/Sustainable-Farming/1987-07-01/The-Suffolk-Punch.aspx (accessed May 4, 2012).
} 
realized that the quality of the land was not "like the county agent had told us; it was not land to really make a living farming off of.”100

Many starry-eyed homesteaders who dreamt of full self-sufficiency quickly realized the futility of the goal. Jubal Stuki vented his frustration in the Green Revolution:

Simple living embodies the concept of getting closer to nature, of homesteading, of eating good organic foods, of getting along with less instead of more, of becoming less dependent upon others and more dependent upon self, of raising our own food, making our own clothes and our own entertainment. Unfortunately, the realities of 'simple living' are not as simple as the dream.

Simplicity is generally defined as the absense [sic] of complexity, intricacy or artificiality. But anyone who has tried a life of self-sufficiency has soon learned that the amount of knowledge and skill, fortitude and hard work — combined with the ability to improvise — that are required sometimes make simple life very complicated. ${ }^{101}$ Williams admited that it did not take long for her to realize that self-sufficiency was nearly impossible, even with retirement pensions. "We never had the extra resources to put into things in like” wind turbines and dams for electricity. "But I would have loved to have been completely self-sufficient” in West Virginia, “but it turns out that takes a lot more resources than a daydreaming city girl might come up with.”102

Ed Grant from South Bloomington, Ohio, tried to coach regional back-to-the-landers through how-to guides in The Green Revolution. He said he had seen too many would-be homesteaders fail because they did not have the right tools. "Well, you can't cut down a tree with

\footnotetext{
${ }^{100}$ Williams interview.

101 Jubal Stuki, “Simple Living Ain’t So Simple,” Green Revolution, November 1976, 7-8.

${ }^{102}$ Williams interview.
} 
a nail file," he wrote, "nor can homesteaders make it without many tools to work their new land." ${ }^{103}$ As former back-to-the-lander Lynn Stasick keenly observed, "How could you expect somebody coming from another area, never having done this sort of thing before, [to] come in and do this when others can't?"104 Indeed, small Appalachian farmers had been struggling to make ends meet for years. Their numbers declined throughout the twentieth century due to soil exhaustion, the limited availability of cultivatable farmland, and increased work opportunities outside of agriculture. Plus, the lifestyle was fraught with hardships. Farm labor was physically demanding, crops and livestock were subject to the whims of nature, and farming consumed an incredible amount of time, something that many alter-natives had less of as they took conventional jobs to help pay for and support their farms.

John Verlenden, who homesteaded in West Virginia, cited the winter of 1977-78 as his impetus for leaving. It had been so harsh that it forced him to realize that he could no longer engage in the self-sufficient lifestyle. The temperatures were too cold and the labor was too demanding for him to be able to continue. “'All of a sudden,” he related, “'life in the country stopped being a game and started being survival for real.'” He was petrified that as he tromped out into the sub-freezing temperatures to fell additional trees for firewood, his reflexes would be so slowed that he would not be able to get out of the way should a tree fall in the wrong direction. “"The snow was so deep that my body effectively disappeared in it while I was doing this cutting, and my feet would be so numb I wasn't sure I could jump out of the way if it hit wrong, took a wrong bite out of the tree and kicked back."' In addition, he had learned to cut

\footnotetext{
${ }^{103}$ Ed Grant, “Letters,” Green Revolution, September 1976, 26.

${ }^{104}$ Stasick interview.
} 
trees through Mother Earth News rather than by an experienced mentor, so as he found himself facing imminent danger he began to recognize the folly of his experiment. ${ }^{105}$

Verlenden's move to West Virginia had been “unpremeditated,” and the “'rashness”” of his decision had come back to haunt him. Like Goldsmith, his marriage fell apart. In addition to suffering under the strain of a harsh winter, the isolation became troublesome. “'We were stuck up there, and we had hardly anybody around us,"” he recalls. ${ }^{106}$ In spite of the efforts to create community support networks with like-minded people, isolation was a major problem for exurbanites accustomed to social outlets. Road conditions, particularly in West Virginia, were bad in the dry season, never mind between November and May. Many in-migrants (and especially the in-migrants who have since left) recalled having to drive through creek beds to get to their hollows, some of which were miles off of the paved highways. Some spoke of crossing ice banks to get in and out of their property, while others reported having had cars stuck and stranded on muddy roads or in creek beds. Homesteader Connie Abraham indicated that she had to stay at home for stretches of two weeks or more because of weather. Paul Salstrom warned Green Revolution subscribers to "beware” when visiting West Virginia. "The roads are usually impassable! That's why back-hollow and ridge-top land is so inexpensive here.” ${ }^{\prime 107}$ Such isolation hindered people's abilities to reach potential agricultural or craft markets, or to take jobs that could provide them with opportunities to develop or add amenities to their homesteads and communes. As sociologist Patrick C. Jobes notes of the migrants in the Gallatin Valley of

\footnotetext{
${ }^{105}$ Agnew, 194-195.

${ }^{106}$ Agnew, 196-197.

${ }^{107}$ Abraham interview; Paul Salstrom, "How it might be on the back roads," Green Revolution, July-August 1973.
} 
Montana, people might have found "inspiration in the beauty and solitude" of remote scenic areas, but “most people who were geographically isolated” eventually “moved away.”108 In spite of some of the reports of abysmal failures at attempts to be self-sufficient, for most homesteaders and communitarians it should be understood as an ideal that existed on a continuum rather than as an ultimate goal that all expected to achieve. The hope was, after all, to regain a sense of autonomy and self-determination, but in reality the lifestyle sometimes restricted people's freedom by tying them to the home and farm. As Jeffrey Jacob observes, "For those who accept the limitations with grace, self-reliance can be a very satisfying, even exhilarating, experience, while the new pioneers who pursue it single-mindedly often find themselves exhausted, plodding after an elusive, constantly receding goal." ${ }^{109}$ Ed Gralla explains:

Well, I'm not self-sufficient. I never will be. It's impossible in this society unless you're living in a cave and rooting out roots, and even then it's somebody's land. So there's no such thing. I'm moving as close as I can to it, but it costs a fortune. I mean, my bills a year to run this place are significant. I don't make any money at all at this. I wouldn’t even try to do that because that's really slave labor. That would make this life a struggle as opposed to a joy.

Although Gralla acknowledged the impossibility of ever being completely self-sufficient, he took comfort in knowing that if the economy collapsed, he and his family would be in a good position to navigate the changes: "If the world crashes, that won't be an issue for anybody anyway. We

\footnotetext{
108 Jobes, 213.

109 Jacob, 91.
} 
have plenty of seeds and knowledge how to survive that." But, "Self-sufficiency?" he concluded, "Not a possibility.","10

The dogged pursuit of complete independence from the economic mainstream sometimes robbed alter-natives of the joy of living close to nature. The point of homesteading was to achieve a higher quality of life and moral satisfaction by remaining focused on nature and the home, by escaping the doldrums of conventional labor, and by understanding that the hard, repetitive, physically demanding work was somehow serving the greater good. Becoming a slave to the farm was hardly part of the agrarian vision. Members of the Kharma Farm in Ulysses, Pennsylvania, likewise realized this truth: “Couldn't someone have told us about all the suffering and hard work and hours of expended energy and all the disappointments and problems?" "Sure it’s all worth it (we didn’t say it wasn’t!), but damn if it wasn’t a hell of a struggle.”111

Because of his childhood experience on a tobacco farm, Jason Rutledge had few illusions about what his life would be like on a rural mountaintop. He moved back to the land in the truest sense of the phrase with a solid grasp of what self-sufficiency and independence truly meant. In becoming a homesteader, he sought to change people's minds about what constituted "modern" technology and hoped to achieve the sense of "dignity" through hard work that he had observed in his grandfather. Others who came to Floyd County, Lincoln County, or other Appalachian communities from urban areas were often a bit less clear about their motives; although they still saw the potential for social change through homesteading, they were generally ill-prepared to navigate life on a rural homestead. Still, a few were determined to see their vision of a new world order forged through some degree of self-sufficiency and closeness with nature realized in the

\footnotetext{
${ }^{110}$ Gralla interview.

${ }^{111}$ The Kharma Farm, “Ulysses, Pennsylvania,” Mother Earth News, July/August 1976: under “Them That’s Doin,” http://www.motherearthnews.com/Do-It-Yourself/1976-07-01/Report-from-Them-Thats-Doin-Ulysses-Penn.aspx (accessed April 13, 2008).
} 
mountains of Virginia and West Virginia. In order to survive, they leaned on each other for assistance. And as they discovered, their native neighbors had even more to offer by way of local knowledge and understanding of how to make it on one’s own. In order to tap into that knowledge, however, they had to overcome some significant cultural barriers. 


\section{Chapter Four}

\section{“Where 'Howdy' and 'It's far out to see you' meet and shake hands”: Early Integration into Appalachian Communities}

Wanda Vest and her husband, Bernard, settled on a piece of land in Floyd County, Virginia, that they purchased from her grandfather in 1947. This was a year after they married, and they received the land along with five head of cattle for five thousand dollars. The land had been in Wanda's family for generations, and the young couple used the cattle to start their dairy business, which grew to average twenty head. But like so many of the New River Valley’s dairy farmers in the post-war era, they struggled under the weight of competition from cheaper markets. ${ }^{1}$ To compensate for the lack of income, Bernard began laying brick in the evenings and on weekends. Wanda periodically took jobs in nearby textile mills, particularly during the winter, to try to supplement his income. They expanded their dairy but were ultimately unable to keep the operation going. According to Wanda, Bernard nearly had a "breakdown" from the stress of his labor, and after a short stay in the Veteran’s Hospital, they approached Virginia Polytechnic Institute to see how they could better manage their farm. Wanda was instructed to keep exact records of "everything that [they] spent on those cattle, and then what [they] made each month from selling the milk.” After returning the results to Virginia Tech, the school told Wanda that the cows had caused her husband "to work to pay for them.” They decided to sell the dairy. They sold “everything," she said, including a sizeable piece of land that they advertised for sale in

\footnotetext{
${ }^{1}$ Historian Ronald Eller notes that the number of regional farms had been in decline since before the beginning of the twentieth century, but that process accelerated even more during the 1950s and 60s, as outmigration accelerated and people found more profitable labor elsewhere. In that period, he claims, "half of the farmers and farm laborers in Appalachia left the land.” At the end of the 1960s, “only about 6 percent of the mountain population was employed full time in agriculture.” See Ronald Eller, Uneven Ground: Appalachia Since 1945 (Lexington: University Press of Kentucky, 2008), 29.
} 
North Carolina newspapers. ${ }^{2}$ They sold their property to the Basons, who moved up from Raleigh, North Carolina, in search of spiritual grounding, self-sufficiency, and community with other people and the natural world.

This type of land transaction between struggling farmers who decided to sell to eager new homesteaders and communitarians occurred throughout the Appalachian region during the 1970s. Struggling farmers like the Vests saw in the young migrants opportunities to relieve themselves of the burden of debts or unprofitable farms, or to obtain cash, so they sold off parcels of land to the willing buyers. Such transactions were the first of many exchanges between Appalachian "old-timers” and the new arrivals. Some of the sellers developed close relationships with their new neighbors—close enough to be considered family in some instances. "When they came in over here, it was company to me,” recalled Vest of the Basons and others who passed through Travianna. Two of Vests’ children were already grown and out of the house-one had been drafted into the Vietnam War-and her youngest was ten years old. She developed a close bond with several of the communitarians, particularly Ruth, whom Wanda recalled would play the guitar and sing at her house. Other Travianna residents developed strong relationships with the Vests; one woman agreed to care for Wanda’s father-in-law while Wanda and Bernard traveled to visit their first grandchild in California. Others would stay with him while the couple ran errands. ${ }^{3}$

Engrained patterns of neighborly reciprocity were often extended to the newcomers; many were quickly incorporated into the community’s social fabric. The process was not always smooth; there were conflicts, rumors, and occasionally confrontations between some locals and

\footnotetext{
${ }^{2}$ Wanda Vest, interview by author, Check, Virginia, August 5, 2011.

${ }^{3}$ Vest interview.
} 
new arrivals who clashed over values and lifestyle preferences. But in spite of initial reactions, nearly every in-migrant had at least one family or local elder who helped to facilitate assimilation. Patricia Beaver identified these individuals as mountain “patrons,” local men and women "who made the transition to the local community bearable and, in fact, possible.” Bernard and Wanda Vest became patrons to their new neighbors. Not only had they sold land to the in-migrants, but they also took the time to make sure that the young people were surviving on their meager incomes. “I was concerned about all them being over there and maybe they didn’t have enough to eat,” she remembered, "but I finally realized they surely knew how to buy food. A big part of them had some college education and they knew they was going to be okay.” Still, on occasion, Bernard offered the males work, and when the young people took care of Bernard's father, the Vests provided them with some form of compensation, be it a pack of cigarettes, food, or use of their house. ${ }^{4}$

Alter-natives may not have moved to the mountains concerned about gaining acceptance from the indigenous population or concerned about what their rural neighbors thought of their focus on self-sufficiency, appearance, or unconventional lifestyles. For some, such considerations would have been the farthest thing from their minds. But even as they built subcommunities of other like-minded people during the 1970s and 80s and enjoyed the physical and social support that they provided, many found that in order to survive on the land, they needed the knowledge and expertise of their native neighbors. Intentionally or not, they became acquainted with the locals who surrounded them and were eventually drawn into the community. This chapter will examine exchanges between newcomers and established residents, paying particular attention to early impressions and the relationships that were built between neighbors

\footnotetext{
${ }^{4}$ Patricia D. Beaver, Rural Community in the Appalachian South (1986; repr., Prospect Heights, Illinois: Waveland Press, 1992), 121-122; Vest interview.
} 
as the alter-natives sought to learn skills from old-timers so that they could survive in the Appalachian countryside.

In Search of Community:

Back-to-the-land movement advocates and scholars have generally understood the act of homesteading in twentieth century America as a declaration of independence, a measure to obtain freedom from the doldrums of industrial labor, or a way to otherwise escape the pressures of modern life. While, as Dona Brown notes, the century’s back-to-the-land movements were full of vagueness and variety, the dominant tropes were ultimately about celebrating independence from economic, social, or political pressures. She contends that while there were many different back-to-the-land visions, there were a few key "powerful motives” that drove people to want to engage in self-sufficiency: "the desire for autonomous and fulfilling work, for independent proprietorship, for a buffer against the ups and downs of the economy, and for a modicum of security in old age. ${ }^{5}$ But this independent strain should not undermine the desire for community that existed in the 1970s-era rural migration turnaround, even among nuclear-family homesteaders. The question of community remains relatively unexplored, although Jeffrey Jacob includes a sub-chapter in his study that examines the extent to which his survey respondents valued being part of a larger community. He finds that sixty percent of smallholders (as opposed to communitarians who actively searched for community), while generally protective of their privacy, still believed that cultivating a "sense of community” in their new areas was "very or

\footnotetext{
${ }^{5}$ Dona Brown, Back to the Land: The Enduring Dream of Self-Sufficiency in Modern America (Madison: University of Wisconsin Press, 2011), 10
} 
quite important.”6 This suggests that there may have been an underlying tension in late twentieth century back-to-the-land impulses that existed between the longing for independence and autonomy and the desire to build communities that could provide members with a sense of identity, security, and purpose, and could lend greater meaning to the self-sufficient experiment. Homesteaders who moved to Appalachia and elsewhere might have couched their decisions to attempt self-sufficient living in terms of freedom and independence, but their actions once on the land suggest that they were similarly looking to become part of a community. What happened in Appalachia for a majority of alter-natives is that even as they attempted to regain autonomy over their lives, they simultaneously began building alternative sub-communities and carving paths into the indigenous community.

Underlying currents of dissatisfaction with the disintegration of community in the postwar era shaped alter-natives' experiences once they arrived in Appalachia. There were, to be sure, people like Jan Salstrom who staked out remote pieces of land miles from civilization to see how far they could go in making it on their own. But many of those people also went to great lengths to remain connected, particularly to like-minded people, by attending co-op meetings, social gatherings, or work parties. Over time, they also found themselves increasingly connected to the indigenous community. As has been discussed, full self-sufficiency was an elusive goal, and alter-natives typically found that they had to rely on the people around them to be able to carry out their agrarian experiment.

Mid-century social commentators were aware of the tension that existed between Americans' independent streak and the perpetual desire for community. "We have learned that

\footnotetext{
${ }^{6}$ Jeffrey Jacob, New Pioneers: The Back-to-the-Land Movement and the Search for a Sustainable Future (University Park: Pennsylvania State University Press, 1997), 187.
} 
man is not self-sufficing," remarked sociologist Robert Nisbett in 1953, "that his nature cannot be deduced simply from elements innate in the germ plasm, and that between man and such social groups as the family, local group, and interest association there is an indispensable connection. We know no conception of individuality is adequate that does not take into consideration the myriad ties which normally bind the individual to others from birth to death." ${ }^{7}$ Nisbett's insight about humankind's need for social networks and support provide an interesting launching point for understanding how and why supposedly reclusive or escapist in-migrants eventually wove their way into Appalachian communities. Along with worries about the weakening effects that "mass culture" had on mid-century Americans was a general concern about what the deterioration of communities might mean for both individuals and families. The baby boom generation in particular had suffered an identity crisis in the absence of traditional communities that provided members with important social, economic, and psychological support. Nisbet theorized that the rise of the modern centralized state had damaging effects on the traditional familial and community networks that once mitigated some of the excesses of external economic and political forces. His book Quest for Community sought to uncover the causes of the widespread feelings of alienation and insecurity. The "modern State" had penetrated “man's economic, religious, kinship, and local allegiances" and in doing so disconnected him from "established centers of function and authority." These dislocations were behind "the twentieth-century’s obsessive quest for moral certainty and social community."8

\footnotetext{
${ }^{7}$ Robert A. Nisbett, The Quest for Community: A Study in the Ethics of Order and Freedom (New York: Oxford University Press, 1953), 229. Emilia E. Martinez-Brawley's discussion of why contemporary Americans search for a sense of community pointed me to a number of sources cited in this section, including those by Nisbett, Theodore Roszak, and the Newsweek article by Morganthau and Maier. See Emilia E. Martinez-Brawley, Perspectives on the Small Community: Humanistic Views for Practitioners (Silver Spring, MD: National Association of Social Workers Press, 1990), 25-51.

${ }^{8}$ Nisbett, The Quest for Community, viii.
} 
Decades later, people still wrestled with the question of community. Echoing Nisbet’s concerns, Theodore Roszak vented that while so many institutions in America had grown larger, particularly the federal government, the American family had shrunk. "Things have gotten too big at the expense of basic structure," he complained. "Some of these structures—the neighborhood, the village, the community of work—have simply been driven into the ground as obstacles to big system efficiency.” The family "lingered on” but only in an weakened condition. ${ }^{9}$ The concern persisted into the 1980s. In 1981, Newsweek reporters Tom Morganthau and Frank Maier theorized that the mass migration to rural areas was a response to fears about the disintegration of the traditional values of "family, home and community" during the postwar era. ${ }^{10}$

Part of this disintegration was due to suburbanization. The commodification of housing prompted many families to move, first out of the cities to the suburbs and then to increasingly nicer neighborhoods. "Increasingly,” writes Lizabeth Cohen, "people from long-established, often highly industrialized, and, by the end of the war, congested and deteriorating urban centers ... left homes near jobs, relatives, and long-established ethnic and religious communities” to move to the suburbs. Middle-class Americans' identity became wrapped up in consumption rather than extended family networks. This process disrupted the traditional support networks found in inner city ethnic enclaves and rural communities. Grace Hale insists that white baby boomers' romanticization of outsiders stemmed not just from fears about cultural homogenization but also from concerns about loss of control over their own lives because of suburbanization, bureaucracy, and changes in family life. That generation lost its sense of

\footnotetext{
${ }^{9}$ Theodore Roszak, Person/Planet: The Creative Disintegration of Industrial Society (Garden City, NY: Anchor Press / Doubleday, 1978), 152.

${ }^{10}$ Tom Morganthau and Frank Maier, “America’s Small Town Boom,” Newsweek July 6, 1981.
} 
identity and grounding in community and sought to reclaim it by rejecting mainstream culture, identifying with marginalized people, and forming new communities based on imagined connections with those cultures as well as nature. ${ }^{11}$

Sociologists argue that “contrived” or "artificial” communities developed in the absence of traditional networks. The emergence of communes and countercultural "tribes" in the 1960s and 70s, as well as the mass migration to rural areas, became part of a widespread search for a “personal solution” to the era’s anxiety and rootlessness. ${ }^{12}$ Emilia Martinez-Brawley believes that the "alternative arrangements that take the place of Gemeinschaft," or a small community in which residents share and have a clear understanding of where they and others stand in relation to each other, flourished in the absence of natural communities. This uprooted generation found "personal salvation" in alternative communities, either in the form of communes or by creating tight-knit networks of friends in the 1960s and 70s. Others, she claims, found identity in fabricated communities like shopping malls. "The smaller the family becomes," says MartinezBrawley, "the more individuals search for purpose and meaning in the larger collective, in contrived groups, and in artificial or utopian communities." ${ }^{13}$

Will Bason, who currently posts many articles and personal reflections on Facebook about both the breakdown and reclamation of communities, has expressed his own frustration with pseudo-communities structured around "sports teams with animal totems." He captured the sentiment of many earlier scholars and social commentators when he wrote, "We all miss our home villages and our tribes." "We all long to belong to and miss the clans and extended families

\footnotetext{
${ }^{11}$ Lizabeth Cohen, A Consumer's Republic: The Politics of Mass Consumption in Postwar America (New York: Vintage Books, 2003), 197; Grace Elizabeth Hale, A Nation of Outsiders: How the White Middle Class Fell in Love with Rebellion in Postwar America (New York: Oxford University Press, 2011), 5.

${ }^{12}$ Martinez-Brawley, 25.

${ }^{13}$ Martinez-Brawley, 26-29.
} 
we evolved in and the social safety net they naturally provided. We feel culturally dislocated because we are! dis located, having lost our connection to our localities in the cultural maelstrom of modern, global civilization.” ${ }^{14}$ Many alter-natives, either through actions or words, lend support to Bason's feelings about the centrality of community and the need to regain a sense of belonging to networks larger than oneself.

One of the problems with replacement communities, at least in terms of their relevance to the back-to-the-land movement, was that they were often based on nostalgia for the past or illusions about what rural communities could offer. As such, they did not guarantee long-term happiness or satisfaction. Patrick C. Jobes, who documented twenty years of quality-of-life migrations into—and out of —-the Gallatin Valley in Montana, argues that the people who were most enthusiastic about wanting to move to the area for its intimate and friendly community atmosphere were typically the quickest to leave. "It became apparent," he recalls, "that those recent arrivals who intensely listed the beautiful environment, the friendly community, and the developed cultural resources as the sources of their future happiness were unintentionally waving a red flag that they were likely to be moving away soon.” Their rootlessness prompted them to move, but it also created problems for the host community. He finds that there was typically a disconnection between what the in-migrants "say they want and then actually do" after their arrival. This created "confusion and conflict with the residents and even within the individuals themselves." They never integrated into traditional community networks such as "family, neighborhood, church, community," and this left them out of reach of the social control and influence of the larger populace. ${ }^{15}$

\footnotetext{
${ }^{14}$ Quoted with permission from author. Will Bason's Facebook page, accessed June 15, 2012, http://www.facebook.com/will.bason.1.

${ }^{15}$ Jobes, 19-20, 77.
} 
Jobes and Grace Hale are somewhat critical of the romanticization of outsiders and rural communities, Hale because it ultimately harmed chances for a sweeping social movement during the 1960s and 70s, and Jobes because it sometimes had dramatic and painful effects on the Gallatin Valley's social, economic, and political landscapes. But Martinez-Brawley, who created her study to be used as a manual for social workers, is more tempered in what "artificial or utopian" communities provide for their members. She believes that "people find meaning in their social role within communities" and "in the participatory responsibilities." People who do not suffer under the weight of complete societal breakdown, or anomie, are still interested in being engaged in a larger community. In her examination of some of the "essential elements" of community—feelings of "solidarity, significance, and security"—she notes the inconsistency with which modern society acknowledges the importance of community. She cites a 1976 Philip Slater study in which he claimed that the counterculture had arisen in part as a response to the individualism of the 1950s. He believed that Americans had become somewhat "schizophrenic," for in one respect they had "pursued competition, success, and material gains," while in another "they sought associations, freshness of air, and communal backyard talk.” Regardless of whether or not community as the predominant social value was in vogue, people would nonetheless compensate by creating their own new communities in the absence of traditional ones. ${ }^{16}$

For the countercultural contingent who engaged in the back-to-the-land lifestyle—-for not all identified themselves as "hippies" — this desire to find community blended with the romantic impulse to head to the countryside and to assert independence through hard work and a relationship with nature. Although the counterculture was born an urban movement, the trend trickled out into the countryside. Cities became seen as "physically intolerable for life" observes

\footnotetext{
${ }^{16}$ Martinez-Brawley, 14-15, 27. See also Philip Slater, Pursuit of Loneliness: American Culture at the Breaking Point (Boston: Beacon Press, 1976), 10-11.
} 
Timothy Miller, and “incompatible with a liberated or tribal lifestyle.” City dwellers became "infected" with "rural romanticism," so a move to the countryside enabled "clans" to "grow and consume" their own food, "breathe clean air, be naked at will, [and] be close to nature and to the cosmic forces. ${ }^{17}$ Countercultural leaders like Allen Ginsberg, adds Miller, supported and celebrated the emergence of tribal families in the rural countryside. “"We are obviously changing,"” observed Ginsberg, “'altering in family structure ... There’s no reason to think it so strange that it might alter in a direction that some groups of people might want. And the tendency toward a commune and community and enlarged family is a very definite tendency."”18 Said Floydian alter-native Fred First, "The whole hippie thing was not just about dressing weird and doing drugs. A lot of it was about relationship to the planet and to neighborhood and community." 19

The trick, especially for the more overt countercultural types determined to carry on with any variety of expressions of personal liberation in the countryside, was finding the balance between a community small enough to make its membership feel connected and valued without being too restrictive or limiting. "It is in the smaller units," explains Martinez-Brawley, "that people probably can achieve recognition and social support.” But, if the restrictions "community places on an individual's freedom result in his or her unhappiness and estrangement, then a community that is a small unit is not the solution. ${ }^{, 20}$ Her statement helps to shed light on one of the reasons why so many people from urban areas left their adopted small town homes after a short period of time. They often went in search of freedom and independence but found instead that they had to constrain them in order to reap the benefits of community participation.

\footnotetext{
${ }^{17}$ Timothy Miller, The Hippies and American Values (Knoxville: The University of Tennessee Press, 1991), 91-93.

${ }^{18}$ Miller, 93.

${ }^{19}$ Fred First, interview by author, Floyd, Virginia, July 23, 2008.

${ }^{20}$ Martinez-Brawley, 36.
} 
Patricia Beaver observed this dilemma in western North Carolina. As newcomers established relationships with their native neighbors, they found themselves curbing expressions of personal liberation in order to get along. A couple profiled in her study, "Larry" and "Linda," moved to the mountains to assert their independence and to enjoy the natural surroundings. Isolation, rather than community, was one of the key impulses that prompted them to move. But their integration into the local culture that happened out of necessity ultimately constrained expressions of freedom, liberty, and solitude. Their eventual decision to leave, Beaver found, was rooted "in the increasing complexity of their involvement with the Rocky Creek community.” Like countercultural migrants elsewhere, “They had a vision ... of a type of existence free from the bounds, rules, and norms of mainstream, or any, society, in communion with the 'natural world,' where free expression of all sorts was possible.” But the couple’s success with their back-to-the-land experiment "was ultimately dependent upon their participation in the traditional community and upon the many acts of kindness that neighbors would trouble themselves to extend.” Beaver concluded, "The very isolation and natural beauty that made the mountains desirable for those seeking an alternative lifestyle also made getting along difficult, and, at times, nearly impossible.”21

To be sure, some in-migrants remained withdrawn from the surrounding indigenous community. But for the vast majority of people who stayed for a period of several years or more, connecting with the neighbors became an integral part of their back-to-the-land experience. In some cases, newcomers developed almost familial relationships with their elder neighbors. But those relationships may have come at the price of curbing expressions of personal freedom. And

\footnotetext{
${ }^{21}$ Beaver, 126.
} 
during the early years of the migration, conflicts occasionally arose when new arrivals pushed the boundaries of propriety that had long been established in the small communities. ${ }^{22}$

No community is without conflict. But alter-natives’ integration into regional communities — whether an intentional process on their part or not—led some, particularly those who remained in Appalachia for years, to forge deep and satisfying relationships with at least a few local families. This was a process that involved misunderstandings and misguided first impressions, as we shall see, but it also opened peoples' minds to different cultures and helped a seemingly rootless generation find grounding and meaning in small Appalachian communities.

\section{Locals’ First Impressions}

During the mid-to-late 1960s, news reports, television, and popular magazines documented the blossoming of the urban counterculture and its subsequent spread into the countryside. Middle America watched as major news networks broadcast images of young people in "bizarre dress" with "long hair" and showcased interviews with prominent countercultural figures like Jerry Garcia of the Grateful Dead, who in one interview with CBS

\footnotetext{
${ }^{22}$ To avoid chalking up constraints on personal freedom to Appalachian or rural parochialism, it should be noted that "all communities" find ways to "safeguard themselves from outside forces impinging on the communal unit." Martinez-Brawley cites studies that examined the 1960s and 70s commune movement to prove this point. Morningstar Ranch in California, for example, at one point welcomed anyone interested in communal living, but it gradually became more exclusive because of the disruptive forces associated with allowing unfamiliar newcomers into the group. New arrivals to any community have the potential to tax that community's resources, raise questions related to growth and development, and challenge existing power dynamics. This may be why, at least publicly, there seem to have been more conflicts between local elites and newcomers in Appalachian communities than between newcomers and old-timers. While problems occasionally arose between neighbors because, in part, "old timers claim a degree of deference, respect, and adherence to prevailing codes of behavior that newcomers are often unwilling to grant," the overt expressions of hostility toward in-migrants typically emerged during periods of public debate about political, environmental, or economic issues. Alter-natives' participation in these debates may have been perceived as threatening to the existing power structure, a topic for subsequent chapters. See MartinezBrawley, 41.
} 
described for audiences the hip vision of a "peaceful planet” via the use of psychedelic drugs. ${ }^{23}$ As the 1960s waned and conditions deteriorated in the cities, hippies migrated into the countryside, much to the consternation of some rural people who had watched with shock and amazement footage of the outlandish youth on television. One West Virginia native remembered the images of the flower children in the late 1960s: "You saw that on the television before they came here, the hippies in San Francisco. You saw that. I mean everybody saw that.” And once it became clear that West Virginia and other areas of Appalachia had become a popular destination for the hippies, “everybody thought, 'Well, here they come. They’re here.,”24

Well before the arrival of the vast majority of permanent homesteaders and communitarians to Appalachia, countercultural young people flocked to regional folk festivals. Festival boosters grew concerned about how to navigate the increased crowds, but more importantly, how to deal with real or perceived threats to indigenous folkways and social codes that the hip crowds posed. Some of these discussions reveal a variety of reactions to the counterculture that in turn provide some insight as to how locals might have responded upon learning that "hippies” were moving in on a more permanent basis. While not all festival attendees planned to move to Appalachia after visiting folk festivals, some did; as mentioned in Chapter Two, the events became one route through which would-be back-to-the-landers were introduced to the region. West Virginia journalist David Peyton commented on the phenomenon in an article that he wrote for the Nation in 1975: "Thousands of them are lured to Appalachia annually. Many buy inexpensive hillside farms and vow to build lives based on the Appalachian values and traditions they have found at folk festivals.” Peyton’s article profiled Mack Samples,

\footnotetext{
${ }^{23}$ YouTube, “1967 Hippie Temptation TV Documentary,” CBS, http://video.search.yahoo.com/video/play;_ylt=A2KLqILyTfRPCmcA.h_7w8QF;_ylu=X3oDMTBrc3VyamVwBH NlYwNzcgRzbGsDdmlkBHZ0aWQD?p=haight+ashbury+cbs\&vid=3F8 (accessed July 4, 2012).

${ }^{24}$ Mack Samples, interview by author, Duck, WV, July 8, 2008.
} 
who at the time organized the annual Mountain State Folk Festival in Glenville, West Virginia. Samples, wrote Peyton, had "watched the mountain folk culture rise from an obscure remnant of past glories to an honored place among those seeking alternative life styles.” At the time, Peyton and Samples were critical of the attention that non-natives had paid to regional folkways in recent years, for they shared the widespread belief that the presence of "outsiders” at the festivals might join with popular media, including mainstream music and television, to snuff out an already anemic folk culture. The popularity of mountain traditions attracted new followers, which in turn introduced new tastes, styles, and techniques to existing cultural expressions, a reality that some natives found problematic. ${ }^{25}$

Samples, like other festival organizers, struggled with the rising popularity of local events and the tension that existed between countercultural attendees and native residents. Peyton observed that "the oldsters" at the Mountain State Folk Festival "kept their distance" from the hippies. For one thing, hip women played the fiddle, and "the old ways of the mountain culture declare that a fiddle is not an instrument to be played by women." ${ }^{26}$ Hygiene was another issue. Years later, Samples reflected on his community’s view of hippies’ participation in festival activities, particularly square dances: “The primary problem that central West Virginia natives had with them was just personal hygiene. They wouldn't clean up, they wouldn't take a bath, they wouldn't wash their clothes, and people just had no tolerance for that at all. Because the people they knew who lived off the land weren’t like that.” And at the festival square dances on “Thursday, Friday, and Saturday nights . . . they just destroyed the dance because nobody would dance with them and yet they all wanted to get on the dance floor. When they'd get on, everybody’d get off.” Samples acknowledged that over the years he became well acquainted with

\footnotetext{
${ }^{25}$ David Peyton, “Appalachian Culture Boom,” Nation, November 8, 1975.

${ }^{26}$ Peyton, “Appalachian Culture Boom.”
} 
several of the newcomers, but, he maintained, "the first impression was that you wanted nothing to do with them.”27

The Fiddlers’ Conventions at Union Grove in Iredell County, North Carolina, provide another striking example of the range of residents' initial reactions toward the counterculture. While Iredell is technically in the Appalachian foothills, every spring since 1924 the county had drawn "hundreds of backwoodsmen, farmers, workers, and plain old 'grits' ... down out of the southern Appalachian mountains” to perform and compete. But as with the Mountain State festival and others, the massive popularity of folk music translated into unmanageable crowds and tension between old-timers and young visitors. By 1969, the Union Grove festival had become so popular that it attracted tens of thousands of people, among them high profile musicians like John Sebastian of The Lovin’ Spoonful and Jerry Garcia. ${ }^{28}$ According to some accounts, old-timers had a pervasive fear that “'the hippies were going to take over.”” As one reporter described it in 1970, the festival had been overrun by “jonquilled” young men and “ "the motorcycle crowd'” who had cast a pall over the ill-fated Altamont festival the year before. Other accounts, particularly those coming from alternative newspapers, purveyed a rosier impression of native and non-native relations. ${ }^{29}$

The pressure was real, however, and it led to a split between festival founder H.P. Van Hoy’s sons, Pierce and Harper, in 1969. The festival, originally housed at a local school, had for

\footnotetext{
${ }^{27}$ Samples interview.

${ }^{28}$ Jim McNally, “Old Time Fiddlers Convention returning to Union Grove,” Statesville Record \& Landmark, March 17, 2012, under “Jerry Garcia Union Grove,” http://www2.statesville.com/news/2012/mar/17/old-time-fiddlersconvention-returning-union-grove-ar-2054114/ (accessed July 5, 2012).

29 “Union Grove Fiddling Festivals: Will the Real Fiddler's Convention Stand Up?” Protean Radish, March 25, 1970, under "Fiddler’s Grove Retrospective," http://www.lib.unc.edu/mss/sfc1/fiddlers/HTML_Final/Articles/1970/1970_032570_ProteanRadish.htm (accessed June 25, 2012); Rob Thompson, “The Lion and the Lamb: The Way It Was at Union Grove,” Source Unknown, April 5, 1970, under "Fiddler's Grove Retrospective,” http://www.lib.unc.edu/mss/sfc1/fiddlers/HTML_Final/Articles/1970/1970_040570_US_01.htm (accessed June 25, 2012).
} 
decades remained a small-scale, local event. But by the late 1960s, the influx of "hippies, radicals, cycle freaks, and zonked souls” led to a battle between Union Grove residents and the Van Hoy family. Early in 1970, word began to spread that the sons would split the festival in two, with Pierce offering a continuation of the festival as it had evolved and Harper providing a festival that catered to local preferences. The Village Voice attributed the problem to some locals' distaste for the more flamboyant attendees, who, they argued, engaged in “drunkenness, dope, and prostitution” on school grounds. The school board voted to stop supporting the convention. One local woman vented that the "hippies” caused normally well-behaved local children to "let go of themselves." ${ }^{30}$ Pierce Van Hoy, however, maintained a less critical view of attendees, at least according to event enthusiast and Great Speckled Bird journalist Steve Wise. After reflecting on the presence of drugs and alcohol at the festival, which resulted in a number of busts by local and state police, Wise added, "Still, bluegrass and old time music are part of an 'outlaw' culture, in a way. Dancing and singing, if not in direct praise of the Lord, is a sin to many upright, devout, God-fearing Christian folk who consider fiddlers to be the scourge of the Devil. But some folks,” including Pierce Van Hoy, “didn’t let that bother them.” Van Hoy “declared he didn’t think anybody should go to jail for enjoying themselves, and if someone were arrested, he'd go to jail with them.”31

At another festival, a promoter's own radicalism blended with that of the countercultural contingent to evoke a particularly hostile reaction from the host community. Appalachian activist Don West, who started a folk festival in 1968 at his recently established Appalachian South Folklife Center in Pipestem, West Virginia, had mixed feelings about the young urbanites who

\footnotetext{
${ }^{30}$ Mike McGee, “Fiddlin \& feudin,” Village Voice, April 9, 1970, under “Fiddler’s Grove Retrospective,” http://www.lib.unc.edu/mss/sfc1/fiddlers/HTML_Final/Articles/1970/1970_032570_ProteanRadish.htm (accessed June 25, 2012).

${ }^{31}$ Steve Wise, “Old Time Fiddlers’ Convention,” Great Speckled Bird, April 10, 1972.
} 
attended his events. The "preacher, teacher, organizer, and poet” purchased the farm in 1966 to establish a Danish-style folk school in order to provide educational "reclamation" for regional high school dropouts. The festival became an extension of the school's mission by providing attendees with the opportunity to celebrate mountain traditions and folk culture. As West's biographer James J. Lorence reveals, the school and festival activities quickly began to rouse local suspicion. West's intent to "train revolutionaries," while subtly expressed in the programming, was not lost on local journalists or state politicians who frequented the site. Folklorist Archie Green, who visited the festival in 1970, indicated that the programming was centered on "political engagement, social activism, nondenominational religious commitment," and education related to the labor and environmental organizing campaigns that were occurring in the Appalachian coalfields at the time. ${ }^{32}$ In 1968, after an article came out in the Princeton Times accusing West of "leftwing tendencies," his center was raided by "a dozen carloads of drunks and half-drunks" who threatened his neighbors and wife (West was away on a youth trip). ${ }^{33}$ The hippies and New Leftists who attended the festival exacerbated the problem; Lorence asserts that they "enraged local residents," leaving the Folklife Center vulnerable to negative publicity. For this and his own personal reasons, West was "somewhat conflicted" about them. $\mathrm{He}$ "resented their condescension and disapproved of their tendency to offend local residents with their dress, habits, and moral relativism.” He felt that the young, middle-class ex-urbanites remained disconnected from the "common" folk because of the way that they had recast themselves as outsiders. ${ }^{34}$

\footnotetext{
32 James J. Lorence, A Hard Journey: The Life of Don West (Urbana: University of Illinois Press, 2007), 192.

33 James A. Haught, “'Pipestem Pinko Purge’ Called Beer Joint Crusade,” Charleston Gazette, October 2, 1968.

${ }^{34}$ Lorence, 194.
} 
Green, while not an Appalachian native or resident, likewise exhibited ambivalence toward the countercultural and New Leftist elements he encountered when he attended the 1970 Appalachian South Folk Festival. Green was critical of the non-natives who he believed misinterpreted local musical traditions, but he also expressed deep respect for a few of them who were serious about confronting Appalachian poverty. He reflected positively on his conversations with Robb Burlage, an Austin, Texas, member of SDS who "seemed to be able to synthesize new Marxism . . . and the current needs of the Appalachian poor.” He also met a young couple from western North Carolina, Peter and Polly Glott, "who had gone native ... by building a log cabin and living off the land. Generally," he reflected in his journal, "I dislike folky people but my affection for the Glotts was instant," particularly since they discussed with Green the problem of record labels cheating traditional performers out of royalties.

Green had less initial success connecting with another young performer and West Virginia alter-native, Michael Kline, who, along with his wife Carrie, went on to become a highly respected folklorist in his own right. Green watched Kline perform Jean Ritchie’s "Blue Diamond Mine” the night before they met and privately criticized the man's introduction of the song because he did not accept Kline’s statement that it had been written "by an old miner down in Letcher County [Kentucky].” Green also disagreed with Kline’s insertion of a new verse about the murder of Jock Yablonski, the 1969 candidate for presidency of the United Mine Workers of America on the grounds that he felt it "strayed beyond Jean's philosophic position.” When they met, Green "stated" rather bluntly, and without having had any proper introduction to the man, that he would "like to talk to Mike about his role at Pipestem." "Mike responded at once, in anger, that he played no role and would not” converse with Green. 
Also telling about both West’s and Green's attitudes toward the non-native folk enthusiasts, Green recalls seeing one native youth, David Morris, who had "aspired to be a collegiate hippy (long hair and beard) until Don steered him back into mountain culture.” On Sunday, as the festival was winding down, Green also encountered Heathcote resident Tony Norris, who gave Green an orange and a copy of the School of Living's Green Revolution. ${ }^{35}$ Norris later followed several of his Heathcote friends to Lincoln County, West Virginia. Reflecting on the attendees, Green concluded that the event had been composed of: "a. traditional singers, b. revival singers, c. political radicals and freaks, and d. non-singers, non freaks. ${ }^{36}$ Townsfolk and the festival organizers, as well as guests like Green, were left to wrestle with the meaning—and consequences—of this "hippie invasion."

As the early 1970s unfolded and Norris, along with thousands of others, settled in Appalachian communities, rumors about nudity, unconventional sexual behaviors, unfamiliar religious practices, drug use, and squalor quickly began to circulate among the locals. First impressions blended with community gossip, and outlandish stories of hippies up the hollers became part of the local folklore. Gossip served an important function in regional communities, explained Patricia Beaver, for it was the "primary means by which local information" was "circulated" and opinions of the newcomers were formed. It also became an important "medium for expressing personal and collective evaluations of behavior" and enabled locals "to avoid

\footnotetext{
${ }^{35}$ Heathcote residents, including some who moved to Lincoln County, West Virginia, continued to cultivate relationships with Don West and participate in his festivals. In 1976, Preston Stern wrote to Green Revolution to inform readers about attempts to establish wind power at Pipestem. He expressed gratitude for Green Revolution's "interest" in Pipestem and suggested that he might write an article on windpower for a future issue. See Preston Stern, "Dear Paul," Green Revolution, March 1976.

${ }^{36}$ Archie Green, Pipestem Log, July 30-August 3, 1970, The Archie Green Papers 1944-2009, The University of North Carolina Libraries Southern Folklife Collection.
} 
face-to-face encounters" while still serving as a means of social control. ${ }^{37}$ One lively example of community gossip comes from author and Lincoln County, West Virginia, native Lenore McComas Coberly. In her book The Handywoman Stories, a short story describes the introduction of a hippie tribe to the local community. It begins with a conversation between two local women, Ruby Louise and Alma Ruth, who have just learned that hippies have moved to their community:

"Well, Ruby Louise, it has happened. I knew it would. It was just a matter of which out-of-the-way place it would be. A bunch of hippies has moved in up at Wysong’s Clearing.”

“Good heavens, are you sure? There isn’t any house up there.”

“They went over to West Hamlin to Waggoner’s Lumberyard and bought a bunch of stuff to build lean-tos to live in while they make bricks out of the clay around Adkins's pigpen!

"I never heard of such a thing. I'd like to see how they do that."

"You’re as bad as Old Man Adkins. He just let them come in over his land back around on the other side of the hill and take their jeep right up to Wysong's Clearing. They are dirty and they are strange.”

“Well, they don’t have a corner on dirty and strange around here, Alma Ruth, but I do wonder who sold them that land. I never thought about it belonging to anybody.”

\footnotetext{
${ }^{37}$ Beaver, 162-163. Sociologist Patrick C. Jobes contends that gossip can also be an important “coping mechanism” for locals who feel stressed or threatened by an in-migrant population. See Patrick C. Jobes, Moving Nearer to Heaven: The Illusions and Disillusions of Migrants to Scenic Rural Places (Westport, Connecticut: Praeger, 2000), 23.
} 
As the story progresses, one of the hippie women visits Ruby Louise's house, and after talking awhile they find common ground through their shared anti-war sentiments and the hippie’s interest in Ruby Louise’s cooking. Ruby Louise then invited the entire group of back-to-thelanders to her house for Sunday dinner, where the young people met Alma Ruth and admired one of her quilts. The alter-natives’ interest in local cultural expressions like cooking and quilting won the women over. ${ }^{38}$

Many rumors reflected concerns about how the new population might challenge local social conventions as well as economic and political structures. As the local criticism launched at Don West's festival suggests, rumors about alter-natives were rampant in regional communities. Both Floyd and Lincoln County in-migrants were subjected to their fair share of tall tales about their lifestyles, as were hosts of other homesteaders and communitarians in other areas. Appearances were one source of gossip and speculation about the new population. Writing to the Lincoln Journal in 1976, a man who identified himself sarcastically as “Lover of Hair” had choice words for some "elderly men" who he claimed he had "overheard . . . discussing (or rather persecuting) people with long hair." "The next time you walk down the street and some guy speaks to you [and] his hair is long don't snarl your nose up and think 'Hippie.' You're not the judge and besides, you might hear a little voice saying, 'Why persecutest thou me?’,39

There were also rumors about theft and other criminal activity. The rumors were typically harmless and short-lived, but occasionally they resulted in local hostility or police action. In Floyd, Wanda Vest recalled hearing a number of rumors about her new neighbors, including her

\footnotetext{
${ }^{38}$ Lenore McComas Coberly, The Handywoman Stories (Athens, OH: Swallow Press, Ohio University Press, 2002), 81-91.

${ }^{39}$ Lover of Hair, “Dear Haters of Hair,” Lincoln Journal, February 11, 1976.
} 
neighbors' belief that "they would steal." ${ }^{40}$ This was a common assumption. Before buying property in Wetzel County, West Virginia, Lynn Stasick witnessed a police raid on his friend's home after a local hunter had peered into the cabin and seen a woodstove that looked similar to his that had been stolen:

We were up in Honey Run, which was a mile up the creek bed at . . . Richard DiPretoro’s house. And, in fact, I think we were just down visiting yet and hadn't even really bought land. And suddenly he said, 'I hear something.' I said, 'No.’ And sure enough, here came these vehicles, and they were county sheriffs people, state police, and they had come that mile up there. Some guy was hunting, and they came in and they searched the place. This was nine thirty, ten o'clock at night. This was really frightening. This almost caused me not to move to West Virginia. But some guy was hunting, and he looked in Chico’s house, peeked through the window, and saw a woodstove that looked like one that he'd had stolen. So he reported that that was his stove .. . They came and they investigated at ten o'clock at night. Go figure that. But this was shortly after these people had just moved to the region, and nobody was used to these outsiders yet. ${ }^{41}$

Given the media attention directed at the use of psychotropic substances among the urban counterculture during the late 1960s, it is not surprising that rumors about drug use were prevalent. Mack Samples captured this rumor in his murder mystery, Hippies and Holiness. The plot is driven by local suspicion that hippies were behind the murder of a young woman in fictitious Vandalia County, West Virginia. Says lead character and murder investigator Corley

\footnotetext{
${ }^{40}$ Vest interview. Rumors about marijuana were not completely unfounded; many people indeed engaged in either consuming or producing the product. This issue will be explored further in Chapter Six.

${ }^{41}$ Lynn Stasick, interview by author, Morgantown, WV, March 2, 2008.
} 
Malone to his friend, Julie, "Of course the rumor is that these hippies are growing a cash crop where the old Appalachians used to raise food. I have heard that this West Virginia soil is excellent for growing pot. They may all be getting rich where the old hill people starved out." ${ }^{42}$ Reality was not much different. Wanda Vest believed that many local residents “didn’t like them because they were into marijuana, which they thought was awful." 43 "Back at the time they all figured we were all making all of our money on pot,” acknowledged Lincoln County homesteader Maggie Hennessey, "and some of us did make some." ${ }^{44}$ Those rumors often targeted the entire population of back-to-the-land in-migrants, although there were many individuals who eschewed both drugs and alcohol for health, religious, or other reasons. But the rumors built upon at least some element of truth in both Floyd and Lincoln counties, as elsewhere. Some locals took the reports with a grain of salt or recognized the newcomers' illicit activities as fitting in with an existing underground economy based on moonshining, which will be discussed in a later chapter. But the rumors also occasionally led to harassment or police action. In 1975, the Lincoln Journal, a paper managed by a man named Gene Brewer, who was hostile to the in-migrants, reported that the local police had found 70,000 marijuana plants on alter-native Jeremiah Greenberg’s property. Greenberg, who moved to the county in 1973, quickly made a name for himself by becoming an outspoken advocate for marijuana use, so he became an easy target of Brewer and local police. But Greenberg was incensed at what he insisted was the misinformation that Brewer had presented to the community regarding his case. “The story that was published about me in yesterday’s paper,” Greenberg wrote, "was not true.” He conceded, "it contained a few grains of truth" but "that's about all." "I never had a pound of

\footnotetext{
${ }^{42}$ Mack Samples, Hippies and Holiness (Marceline, Missouri: Walsworth Publishing Company, 1999), 125.

${ }^{43}$ Vest interview.

${ }^{44}$ Margaret Hennessey, interview by author, Hamlin, West Virginia, July 3, 2011.
} 
pot in my home” or “70,000 plants on my land. These things aren't true. They are lies.” 45 The newspaper in Floyd took a more neutral stance toward the in-migrants, but the local sheriff did not. From the late 1970s until the late 1980s, sheriff George Branscome made it his personal mission to eradicate the county's pot stands. He often based his raids on leads that had been provided by locals who had either heard about their in-migrant neighbors engaging in drug cultivation or witnessed it for themselves. ${ }^{46}$

Rumors about sexual activity and nudity were equally rampant. Timothy Miller surmises that what happened in Wheeler's Ranch in Sonoma County, California, likely occurred in areas across the nation: “one neighbor regularly took in the scene through binoculars.” ${ }^{47}$ This reportedly happened in Harmonsburg, Pennsylvania, where a group of roughly thirty hippies had purchased a farm in 1968. According to Ramparts Magazine, "the farm at Harmonsburg was merely a curiosity” in its earliest days. "For Sunday diversion, local people would pack their kids into the family auto and drive” out to catch a glimpse of the strange new arrivals. The commune’s “spokesperson,” George Hurd, decided to open the commune to visitors in an attempt to stave off rumors, but his decision came back to haunt him. Local teenagers began visiting and, after one of them went to the hospital with a case of hepatitis, "the regional health officer went on the radio urging all residents to keep away from the hippie farm.” The result was a "hepatitis scare of bubonic plague proportions.” As a result, the community shut out the hippies from all businesses and the police raided the farm, charging them with "maintaining a disorderly house,” a law implemented in the 1860 s. ${ }^{48}$ One of the most outlandish rumors related to sexual behavior was directed at Lynn Stasick and his cohort: "that we had come down from New Jersey

\footnotetext{
45 Jeremiah Greenberg, “Dear Mr. Brewer,” Lincoln Journal, September 24, 1975.

${ }^{46}$ Mike Sager, “There’s Pot in Them Thar Hills,” Washington Post, August 15, 1981.

${ }^{47}$ Miller, 218.

${ }^{48}$ Robert Houriet, “Communing in Meadville,” Ramparts Magazine, November 30, 1968, 10-11.
} 
and bought this property and built all kinds of little buildings so women could come in and lay. In other words, we were developing a farm-like whorehouse.”49

A few alter-natives have admitted that they remained rather oblivious to the local culture or they chose not to concern themselves with what people thought of their appearance or lifestyle choices. “If people were talking about us,” said Floyd alter-native Colleen Redman, “I just didn’t hear it or care or realize it." ${ }^{50}$ Maggie Hennessey realized many years after moving to Lincoln County that her tendency to go barefoot might have been offensive to locals, particularly those who lived at or near the poverty level. But others were well aware of what was being said about them, so they made attempts to temper expressions of countercultural values and abide by local social codes, at least while out in public. A Virginia alter-native wrote in anger to Communities after having received an issue with nudity on the cover. Annoyed by the magazine’s lack of consideration for homesteaders trying to assimilate to the local culture, the person wrote: "I hope to be able to enjoy 'Communities,' but find it difficult when I receive an issue with nude people on the cover through the small rural post office in my community. I am not uptight about nudity, but most of my friends and neighbors here are, and their friendship and trust are more important to me than your magazine.” The Virginian requested that future magazines be sent in a paper covering and then admonished Communities to "take into consideration the reaction of people in those communities to the cover and other pictures." ${ }^{51}$ Joanie Goldsmith indicated that members of her alter-native cohort typically hid marijuana use from most locals, although one or two neighbors became close enough with them that they felt comfortable using it in front of them. ${ }^{52}$ And Goldsmith also explained that her group of in-migrants tried not to "flaunt" their

\footnotetext{
${ }^{49}$ Stasick interview.

${ }^{50}$ Colleen Redman, interview by author, July 23, 2008.

51 A Resident of a Rural Virginia Community, "Readback," Communities, Oct./Nov. 1973: 2.

52 Joanie Goldsmith, interview by author, June 24, 2011.
} 
educational backgrounds in front of neighbors. She and others had grown somewhat selfconscious because they overheard people say, “'Well, they have all this book learning. What, do they think they're better than us?” Their conversations with other alter-natives might have contained more intellectual content, but those with neighbors took on "more of a hands-on, how do I survive” quality. This last point suggests that there were some important differences that the two parties had to navigate, particularly related to class.

Navigating class-based differences:

In Mack Samples' preface to Hippies and Holiness he reveals that "many mountain folks looked upon the invaders as a threat to their serenity,” but he also acknowledged that some individuals "accepted and encouraged" the folks who came seeking to learn about Appalachian traditions. The main character, Corley Malone, and his counterpart, local state trooper Sam Somerville, found an inroad into the hippie community through shared interest in music. In fact, the first time Malone met one of the hippie "patriarchs" was during a square dance at a local beer joint. His first impression of the newcomers was that they looked ridiculous trying to emulate local dance styles. But through Malone Samples offers a deeper analysis of one of the key impressions that shaped early relationships between old-timers and newcomers. When Malone visited the newcomers' farm, which had at one time been owned by a local old-timer, he immediately recognized that the young people came from affluent backgrounds. The hippie women, introduced as "Sunshine, Moonglow, and Stargirl," smiled at Malone, and as they did, the character noticed, “even though they were unkempt, they all had perfect teeth and had probably been attractive at one time.” The observation continues: 
It was pretty widely known that most of these lost souls that folks called hippies had come from prosperous backgrounds and had enjoyed all of the advantages that kids who grew up in West Virginia did not even know about. Carpeted bedrooms, visits to museums, orthodontists, and big league baseball had been commonplace to them. Most of the native kids who grew up in holders like Sugar Camp never even saw a dentist until they were grown and got out on their own. But these kids from the upscale world found life up the hollers quaint, the quaintness that young West Virginians had been running from since the mid-1950's. ${ }^{53}$

Alter-natives’ privileged backgrounds put them in the unique position to choose Appalachian quaintness over conventional living, and this was sometimes a source of confusion, and occasionally frustration, for local residents. This reality was not lost on some of the alter-natives, who realized that natives struggled to understand why they had rejected the trappings of modern life. “We don’t fit into any particular” mold, explained Jayn Avery. "We're both have-nots and haves," the "educated poor." 54

Even those alter-natives who came from poorer backgrounds in other states realized that they were still better off than many of their Appalachian neighbors. Responding to Jayn Avery's comment, Colleen Redman asserted, "I was pretty have not for a long time!” She contended that she was able to identify with local farmers because of her own working class roots. "I took college courses but I never went to college. I relate to them in that way, the salt of the earth, kind of ... and I had a grandmother that did a lot of this stuff. Canned with the wax on the jars, foraged for mushrooms.” Redman's interests in those types of traditions helped her to connect

\footnotetext{
${ }^{53}$ Samples, 83, 128.

${ }^{54}$ Jayn Avery, interview by author, Floyd, Virginia, July 23, 2008.
} 
with locals in Floyd. But in other cases, it fostered misunderstanding. Lincoln County alternative Maggie Hennessey remembered a general impression among locals that she and her cohort came from well to do families. Hennessey had lived in poverty in Vermont although she conceded that her background involved "a richer poverty" than what existed in West Virginia at the time of her arrival. Her husband, Bill, with whom she moved to the county, had come from wealth though, as had many other in-migrants. She realized that locals likely believed that all of the in-migrants were wealthy because they were rich enough to come to the county and buy land. The fact that they could afford property in a county with a $25 \%$ poverty rate left them subject to rumors and speculation about their intentions, even as they developed relationships with their neighbors and people in town. One of Hennessey's mountain patrons, Lilly Burns, had grown blind, and after breaking her hip, she was admitted to a nursing home in nearby Teay's Valley. Maggie recalled going "every week to visit her just because she was a neighbor, and ... [she] would feed her.” After Lilly died, Maggie and her husband sought to purchase Lilly’s property. The land was in heirship, and since Lilly had no direct descendants, Bill was faced with the overwhelming task of contacting her remaining nieces and nephews. Maggie recalled, "Bill spent months phoning people because they were all over the United States. And we finally got the piece of land. So my neighbor said to me, he used to live down the road, he goes, 'So Lilly gave you the property?' And I said, 'No, we bought it.' And he says, 'Oh, I thought that's why you were taking care of her.' And that's the attitude,” she concluded, "that you take care of somebody in hopes that they're going to give you what they have. And you're only taking care of them for that. You're not taking care of them for the goodness of your heart. And I says, 'No, I took care of her because she was a nice person and I was her neighbor, and no, we bought the place.' And he was totally shocked.",55

\footnotetext{
${ }^{55}$ Hennessey interview.
} 
Given the region's history of absentee land ownership and unethical practices in the way that extractive industries, speculators, and other industrialists obtained land and mineral rights from residents, it is not surprising that there would have been some suspicion about alter-natives' motives when it came to purchasing property. But it should be noted that land sales to countercultural in-migrants also provided people like the Vests opportunities to relieve themselves of heavy debt loads or otherwise obtain expendable cash. Losing family land could be emotionally painful, but at the same time, it provided them with important economic opportunities. Patricia Beaver's contention that some western North Carolinians preferred to sell their land to homesteaders rather than to summer homeowners or real estate developers may also have rung true, particularly for Floydians who lived in areas bordering the Blue Ridge Parkway. Alter-natives' reverence for the land likely made selling to that population more palatable than to people who wanted to dramatically alter the landscape by erecting fences, building roads, putting up security lights, and building sprawling homes or A-frames in natives’ viewsheds. ${ }^{56}$

One of the more contentious issues was regarding alter-natives' use of welfare services. On several occasions, people already frustrated with high welfare rates vented that the back-tothe-landers, who they perceived to have come from wealthy backgrounds, took advantage of government assistance. In a diatribe against the New River Community Action Program's suggestion that Floyd County schools adopt a free breakfast program, Melvin Simmons countered that the money to support the program would come from taxpayers who were already supporting "the newcomers who have moved into the area to take advantage of the federal giveaway programs." ${ }^{57}$ The frustration often manifested itself most visibly during periods of debate about development such as surface mining. In 1975, a person who addressed him- or

\footnotetext{
${ }^{56}$ Beaver, 124.

${ }^{57}$ Melvin L. Simmons, “No Free Breakfast,” Floyd Press, March 13, 1980.
} 
herself as "Bah Hum Bug” responded to another letter from newcomer Ann Contois Farewell who argued against strip mining in the county: "I could not help but wonder if the lady is among the many recent arrivals to this state whose purpose seems to be buying cheap land with out of state funds then posing as poor and destitute and getting on the welfare programs of the state and federal government.” The person continued, "Yes, they really love this place and people for what they can take we poor foolish hill-billies for. They love to swell our relief rolls." ${ }^{58}$ There was some truth to this kind of accusation. Pete and Margie Shew, who moved to the county in 1971, confessed to the Associated Press that they had, on occasion, relied on food stamps for survival. ${ }^{59}$ Joanie Goldsmith also recalled having had food stamps at times, and her husband, and Tony Norris’ wife Sue, even went to work for the county’s welfare office. ${ }^{60}$ But others, like John and Jan Salstrom, refused to rely on government assistance and took offense at the suggestion that they had. In 1978, during a contest over whether or not to allow a coal company to open a surface mine in Lincoln County, Salstrom expressed his dismay at the notion that had been put forth by the editors of the Lincoln Journal that the in-migrants, many of whom fought the mine, had swelled relief rolls in the county. He listed several of the "nasty jobs" that he had worked in order to keep his family off of welfare and then challenged readers to consider whether strip mining would offer a permanent solution to the county's problem of poverty and dependency on federal aid. ${ }^{61}$

Indeed, there were several periods, particularly in Lincoln County, when the editor or journalists at the local newspaper expressed significant hostility toward the new arrivals for their

\footnotetext{
${ }^{58}$ Bah Hum Bug, “Dear Sir and To Whom it May Concern,” The Lincoln Journal, March 19, 1975.

${ }^{59}$ Stratton Douthat, "Back to the Earth,” The Lincoln Journal, October 24, 1973.

${ }^{60}$ Goldsmith interview. Although this is not documented, there may also have been frustration among some locals with the newcomers' ability to take local jobs since many of them came with college educations.

${ }^{61}$ John Salstrom, interview by author, Hamlin, West Virginia, December 18, 2008; John Salstrom, “Editor,” Lincoln Journal, September 6, 1978.
} 
reliance on welfare and other issues. In 1979, the Charleston Gazette reflected on the back-tothe-land movement in West Virginia in a piece titled “'New Pioneers’ Rooted in State.” Journalist Strat Douthat remembered the "suspicion" that "farm folk" had toward the hippies, but, he added, the "suspicion melted as time went by.” The newcomers had found jobs, ceased to rely on food stamps, and "became surrogate children of the old folks" who had lost their own offspring to outmigration. ${ }^{62}$ Lincoln Journal reporter Paul Akers railed against Douthat’s assessment. He presented a scathing critique of the "beard and bead crowd" that had come, not as people seeking refuge from the city or bringing new talent and energy to rural populations, but as "cultural carpetbaggers" intent upon "fabricating” the idea of Appalachian folk culture for their benefit. He compared the true poverty of native West Virginians like journalist Gaylen Duskey, who grew up in a cabin with a dirt floor in Gilmer County, to the self-imposed poverty of the inmigrants:

The poverty of the Duskeys directly opposes the inherited affluence of most of the people who wanted to hand him a dulcimer and keep him in bib overalls. My observations about the Northern kids who came to West Virginia in the '60s and '70s are that they were generally from well-to-do families, disdained most conventional values, and had been deeply pocked by the epidemic of anomie-the collapse of the social structure, characterized by alienation and rootlessness.

Akers asserted that their biggest fault was their seriousness about their mission, which involved activities that reflected their "extremist environmentalism" and concerns about quality of life. And in response to Douthat's assessment that the back-to-the-landers had "settled in and gained acceptance," he acknowledged that while "in many cases, that is true ... you hardly need

${ }^{62}$ Strat Douthat, “ 'New Pioneers’ Rooted in State,” Charleston Gazette, February 11, 1979. 
seismographic sensitivity to detect a tension and hostility that still exists between some of the immigrants and many of the native-born Lincoln Countians.”63

While Akers' bitter analysis of the alter-natives should in no way be considered representative of the entire Lincoln County_or Appalachian-population, his concept of “cultural carpetbaggers” leads to an important final point about undercurrents of animosity that might have been felt toward alter-natives and their real or perceived class status. Alter-natives who came in part because of their impressions of regional folk traditions and quaintness may have run up against a century-long history of Appalachians’ interaction with middle and upper class urban folk enthusiasts and reformers (sometimes these people were one and the same). Over time, these interactions built up local ambivalence, or even animosity, toward upper class non-natives who took interest in Appalachian culture. While this animosity should not be overstated — for many relationships were built on shared interest in folkways — there has been a long-standing perception of Appalachia as quaint, a perception was developed in part by upper class reformers who moved into the mountains during the late $19^{\text {th }}$ and early $20^{\text {th }}$ centuries in order to ease anxieties about the restless laboring classes who could potentially incite revolt. It was no coincidence that as mountain feuding and moonshining began to attract national attention at the end of the $19^{\text {th }}$ century, middle and upper class Protestant women from the Northeast, as well as Protestant ministers, began to turn their attention away from southern blacks (southern whites proved to be too hostile to their mission) and toward mountain whites. These reformers sought to bring America’s marginalized populations into the mainstream by establishing settlement schools, churches, and other institutions that could instill patriotic values while celebrating distinctive_-and select—-local traditions. Enthusiasm for Appalachian crafts, music, storytelling, and other expressions of folk culture lingered on throughout the first half of the

\footnotetext{
${ }^{63}$ Paul Akers, “Akers Away,” Lincoln Journal, February 14, 1979.
} 
twentieth century. But those cultural expressions were also shaped and molded to fit middle-class consumers' tastes and values, so the power to shape cultural expressions was often wrested away from the producers. ${ }^{64}$

The mid-twentieth century folk revival that attracted some young people to the mountains was perhaps more innocent in its political motives than the earlier revivals that were intent upon integrating mountaineers into the economic and social mainstream, but the two groups shared a universal quality in their regard for folk culture. Referring to late nineteenth and early twentieth century middle-class consumers of folk culture, historian Jane Becker describes a phenomenon that lingered on into the later twentieth century. They "often sought out people who, they imagined, lived in tightly knit societies, close to the soil, where life more closely resembled a preindustrial and precapitalist ideal. Folkways ... flourished in” rural areas not affected by industrialization. Relationships were "presumably personal and informal, the community took care of its members, human and spiritual values reigned, and beauty and value lay in carefully crafting from raw goods the material necessities of everyday domestic life.” “Traditional practices, many believed, might be restorative, uniting body and spirit, nourishing the soul, encouraging self-reliance, and upholding the family. They might provide a mythic source of collective identity, a mirror in which to view oneself, and a means to understand and come to grips with the contemporary world.”65

Rootlessness and anomie drove the baby boom generation to seek meaning and purpose by identifying with marginalized groups. And as people sought to return to the land in the 1970s,

\footnotetext{
${ }^{64}$ David Whisnant, All that is Native and Fine: The Politics of Culture in an American Region (Chapel Hill, NC: University of North Carolina Press, 1983), 5-16. For more information on the Appalachian craft revival and the construction of the Appalachian region in American consciousness, see respectively Jane Becker, Selling Tradition: Appalachia and the Construction of an American Folk: 1930-1940 (Chapel Hill, NC: University of North Carolina Press, 1998); Henry D. Shapiro, Appalachia On Our Mind: The Southern Mountains and Mountaineers in American Consciousness, 1870-1920 (Chapel Hill, NC: University of North Carolina Press, 1986).

${ }^{65}$ Becker, 3-4, 5.
} 
the notion that a traditional culture was available to help them find restoration through traditional practices became a major attribute. Shared interest in traditional folk expressions connected oldtimers and the alter-natives in many instances, but it also opened them up to criticism from people like Paul Akers, who likely felt challenged or threatened by their economic and educational backgrounds, or Mack Samples, who believed that their influence might alter or further weaken traditional expressions.

Local attitudes toward antipoverty back-to-the-landers

The alter-natives who sought to alleviate poverty by advocating back-to-the-land lifestyles occasionally faced even greater hurdles with community relations. Like the alternatives drawn to Appalachia for cultural reasons, antipoverty homesteaders occasionally confronted animosity or downright hostility that was rooted in a long history of non-indigenous involvement in regional social, economic, and political issues, particularly related to the poor. The Appalachian Volunteers chronicled in Thomas Kiffmeyer's Reformers to Radicals is a case in point; the young idealistic antipoverty workers, sincere as their desire to alleviate poverty might have been, early on accepted the culture of poverty model for understanding mountain indigence; they believed that mountain residents' culture, and particularly its fatalistic outlook, had ensnared them in generational depravation. Gradually, however, they came to realize that poverty was the result of structural deficiencies tied to capitalism and, more specifically, to extractive industries and corrupt politicians. Challenging the power structure in eastern Kentucky, particularly as it related to their involvement in anti-strip mine activities, caused the program's demise. Similar events occurred in Mingo County and other communities in West 
Virginia in the 1960s, even to the point that top public officials like Robert Byrd got involved, and these conflicts drew national media attention. ${ }^{66}$

Needless to say, public memory of the conflicts between regional political machines and antipoverty warriors in Central Appalachia had not faded by the time the back-to-the-land movement began in earnest. In the Mountain State, homesteaders and communitarians who hoped to uplift the poor by advocating decentralization and simple living based on small-scale agriculture inadvertently moved into a political hornet's nest. Sometimes their antiwar activism exacerbated hostility from locals who took pride in their sons' and daughters' willingness to serve in Vietnam. In other cases, their involvement with environmental, social, and political issues threatened the local power structure, which subjected them to verbal and occasionally physical harassment.

Two cases in West Virginia illustrate the types of tension that could exist when there was a clash between the antipoverty back-to-the-landers' ideals and those of the locals. The first was in Lincoln County, a county with one of the highest poverty rates in the state. ${ }^{67}$ In 1969 , a group of Catholic Workers established what they called an "agronomic university” on seventy acres of land in order to "present one alternative style of life” to impoverished West Virginians: communal-based self-sufficiency through decentralization and subsistence farming. The Catholic Workers, unlike some of their homesteading counterparts, were not interested in merely retreating or modeling a different way of living, although that was certainly part of their mission.

\footnotetext{
${ }^{66}$ See Thomas Kiffmeyer, Reformers to Radicals: The Appalachian Volunteers and the War on Poverty (Lexington: University Press of Kentucky, 2008); Huey Perry, They'll Cut Off Your Project: A Mingo County Chronicle (1972; repr., Morgantown: West Virginia University Press, 2011).

${ }^{67}$ This is based on a 1980 report from the Appalachian Regional Commission. Interestingly, the four counties ranked with higher poverty rates were also ones to attract significant populations of back-to-the-land in-migrants: Braxton, Calhoun, Clay, and Webster. See "Poverty Rates, 1980: Appalachian West Virginia,” Appalachian Regional Commission, under "Poverty Rates, 1980, West Virginia" http://www.arc.gov/reports/region_report.asp?FIPS=54999\&REPORT_ID=13 (accessed July 15, 2012).
} 
Instead it was grounded in liberation theology, so as new residents they quickly became involved in the social and environmental issues that plagued the county during the 1970 s and 80 s. ${ }^{68}$

Although Catholic in-migrants have since been accepted as part of the community, they had a rough start. Maggie Hennessey, the granddaughter of Catholic Worker co-founder Dorothy Day, explained that part of the problem was that antipoverty activity in the mountains was often seen as "insulting." Further, Catholics were viewed with suspicion in the predominately Baptist community. She reported that the Catholic Workers who moved there a few years before her, as well as the well-intentioned Jesuits who came to promote social and environmental justice during the 1970s, “weren’t real welcome” in the county. Catholic Worker Chuck Smith’s antiwar sentiments made problems worse; his farm had welcomed draft resisters who visited from other states or after release from the Federal Youth Prison in Ashland, Kentucky, and his protest at a Fourth of July celebration in the county seat of Hamlin resulted in him being thrown into the Mud River by a Vietnam veteran. ${ }^{69}$ Catholic Workers also became actively involved with the local anti-strip mining campaigns that divided the community in the 1970s and 1980s, as well as issues related to welfare rights, women's rights, and other social justice issues.

The Catholic Workers’ involvement in the anti-strip mining campaigns elicited particularly venomous responses from local elites and out-of-work miners, which would at least partially explain why Paul Akers, in his response to the Charleston Gazette's articles on the state's "New Pioneers," singled them out in his diatribe against the alter-natives. While in his response to the Gazette he railed against the homesteading population in general, he minced no words when speaking of the Catholic Workers. "A striking number were backslidden Catholics,

\footnotetext{
${ }^{68}$ Michael Tierney, interview by author, Charleston, WV, March 23, 2011.

${ }^{69}$ Hennessey interview; Chuck Smith, “The Farm,” Green Revolution 11, September 1971.
} 
pumping into their spiritual vacuum, one pseudo-Theology or another,” including

environmentalism and "union agitation. And they were nothing if not devoted to their particular belief-system . . . Many of their ideas sounded to the average West Virginian like fingernails on a blackboard.”70

Early resistance to the Catholic Workers should not suggest that all Catholics in Lincoln County or elsewhere in Appalachia were met with resistance or had difficulties integrating into the local community. ${ }^{71}$ Michael and Marcel Tierney, both of whom came to West Virginia as volunteers through Catholic organizations in the late 1970s, later helped to found a community center in Big Ugly at the far southeastern corner of the county in the early 1990s. The Tierneys never considered themselves countercultural, but like their homesteading counterparts, they embraced the idea of living close to nature and living a sustainable and self-sufficient lifestyle. When asked how the locals had received their organization, the Tierneys remarked that they were accepted because their community involvement had begun with their role as concerned parents rather than as missionaries. They became involved in a grassroots fight to keep a local elementary school from closing, and that afforded them local respect. When the county school board proceeded to close the school in spite of the community's wishes, the Tierneys proceeded to fight to obtain access to the school to use as a community center. Michael recalls his initial

\footnotetext{
${ }^{70}$ Paul Akers, “Akers Away,” Lincoln Journal, February 14, 1979.

${ }^{71}$ Resistance or suspicion seems to have been targeted more toward Catholic missionaries than in-migrants who were Catholic. Another group of missionaries to the coalfields in southwestern Virginia likewise had difficulties being accepted in the earliest years of their work. Coal producing areas of Virginia like Big Stone Gap attracted antipoverty workers during the late 1960s and 70s, including a group of Catholic Glenmary Sisters who organized the Federation of Communities in Service, or FOCIS, in 1967. This group, according to Ronald Eller, was more "aggressive" in terms of how they approached the issue of poverty compared to many community action programs, promoting to the full extent President Johnson's idea of maximum feasible participation of the poor. The Glenmary Sisters struggled to adapt in large part because of their habits. A woman named Anne Leibig, years after having made her first round of visits to mountain families, was reportedly told that they believed her to be "a witch in her dark robes." Although they were eventually granted permission to wear lay clothes, some residents still believed that they were engaging in "subversive" activities, only in an undercover manner. See See Eller, 123-124; Helen Lewis and Monica Appleby, Mountain Sisters: From Convent to Community in Appalachia (Lexington: University Press of Kentucky, 2003), 36, 92.
} 
concern that there would be little local interest in starting educational programs because people were so "discouraged" that the school system had hesitated to grant them access, but when he organized a meeting to reopen the facility, twenty people showed up. They restored the school and eventually used it for educational programming and other purposes. Because of their efforts to work in tandem with the community on an issue of shared concern, they gained the community's trust. $^{72}$

The Tierneys conceded that over the years there were "times that [they had] been part of the rumor mill for taking leadership” roles. And their neighbor admitted to them years after they had moved to Lincoln County her belief that they would not "last six months" in the area. But they insisted that any suspicion or rumors about their activities resulted more from to their prominence in the community than from the fact that they were considered "outsiders." The "local leaders," they believed, had it even worse. They often fell victim to the Appalachian admonition against "going above your raising" and were occasionally reprimanded or scorned by the community if they acted in ways that contradicted local norms. Michael and his wife, an attorney, often wound up on the receiving end of local gossip. "Because we're not kin to everybody,” he explained, "we get off scott free ... It's like we're the safety valve that people can tell stories and know that will never get back, that they told the family story.” Marcel added, "people just drive in and pull up" and ask Michael if he is a lawyer, and when he says no and points them to her, they ask, "Well, you have a couple of minutes?" “They'll sit on the stoop and they tell me the ins and outs of their particular legal problem and I'll try to point them in the right direction. They're very glad to have talked to a lawyer and so they go on their way."73

\footnotetext{
${ }^{72}$ Tierney interview.

${ }^{73}$ Tierney intervew.
} 
The difference may have been, then, in how well-meaning alter-natives approached community involvement. Small communities typically resist rapid, systemic change. "Because influence is particularistic," observes Martinez-Brawley, "the narrower the issue the more feasible the concessions vis-à-vis the overall community equilibrium." ${ }^{74}$ This may help to explain why the Teirneys, whose involvement with a very localized issue demonstrated shared values between themselves and other local parents and did not threaten the power structure, were more openly received than the Catholic Workers who had values that contrasted with some members of their targeted population. In-migrants who came in anticipation of making dramatic change to the political or economic structures of a community often found themselves being targeted as radical or simply dismissed. In order to be accepted as an insider, newcomers had to understand how to act during their interactions with other community members. This included properly navigating local power structures. Those in-migrants who tried to act as "experts" or to assert authority on issues related to the community tended to be dismissed as outsiders and excluded from the decision-making process altogether. ${ }^{75}$ "Incomers are expected to take their behavioral cues from the locals," claims sociologist Scott K. Phillips, and "they should not presume to alter local ways.” Incomers were welcome to participate in community activities— and their engagement could afford them insider status—-provided they did not act against accepted forms of behavior or attempt to change local behavioral patterns. ${ }^{76}$

An even more dramatic case of community hostility toward well-meaning in-migrants occurred in Pendleton County, West Virginia, where several newcomers started a school with

\footnotetext{
${ }^{74}$ Martinez-Brawley, 58.

${ }^{75}$ Sociologist Lisa Moran finds that some natives can be perceived as outsiders if they do not conform to accepted patterns of behavior within the community. Lisa Moran, "Negotiating Boundaries or Drawing the Line? Transcending 'Insider/Outsider’ Distinctions in Connemara,” Irish Journal of Sociology 16.2, (2007): 145-147. ${ }^{76}$ Scott K. Phillips, "Natives and Incomers: the symbolism of belonging in Muker parish, North Yorkshire," in Symbolising Boundaries: Identity and diversity in British cultures, edited by Anthony P. Cohen (Manchester, UK: Manchester University Press, 1986), 151.
} 
outdoor educational programs akin to Outward Bound. The Woodlands Institute, later renamed the Mountain Institute, was subject to some of the same rumors typical of other communities. In a memoir based on his life in Pendleton County, John O’Brien conveyed some of the remarks that he had heard in the community regarding the newcomers:

Some say they’re Communist ... I heard tell they got tunnels dug all under that mountaintop ... I tracked a wounded buck onto that land up there and found this small plane hidden under a brush pile. You tell me now . . . They’re growing marijuana . . . It’s all some experiment on us ... All of 'um go to different churches, spread'n out you know ... One of them cults . . I've seen the CIA set things up like it in Africa ... Oh, it's a money-making deal. These elite people with connections have found a way to get rich ... I can’t rightly say what they're up to, but it’s like my neighbor said just the other day, they bear watch'n.

But problems extended beyond mere speculation about the newcomers' intent. According to O’Brien, the school was founded as a wilderness school for children of east coast elites, but by the late 1970s, its mission had changed to focus on serving West Virginian students who hoped to go to college. The local newspaper announced that the school was to receive hefty sums of money from state and federal sources to become more sustainable. O’Brien noted that while the school's actual proposed activities varied, its mission was based on "advancing mountain culture and preserving mountain environments.” He claimed that the school had failed to clearly articulate its mission to the local population, which elevated the level of suspicion that locals had toward the “come heres,” as they were called. After Woodlands Institute founders Daniel TaylorIde and Jim Underwood attempted to work with state politicians to try to implement experimental educational programming in county schools, the local tolerance for the new arrivals 
collapsed. As O’Brien explained, “State politics has been, and still is, notoriously corrupt, and people around the state are not convinced that Charleston has their community's best interests at heart.” He quoted a local man, John Sites, to illustrate his point: “ 'These people think we're a bunch of ignorant hillbillies. They talk to us like we're morons. You get that bunch cozying up with the crooks in Charleston, and it can't be good for us. You watch.”,77

Jennifer Taylor-Ide, a Woodlands co-founder, believed that O’Brien's account did a "disservice" to the community "because of how he employed those controversies" in the book. It looked very unfavorably upon Woodlands' founders and failed to highlight areas of cooperation and respect that she felt had been cultivated with locals. Taylor-Ide countered that her cohort, along with several other newcomers, have been "hugely influential” in the community, particularly due to their work in education and health care. In contrast to O'Brien's assertions, she reported having had very close and positive relationships with neighbors surrounding Woodlands; one woman in particular taught her gardening and other skills. Still, she admitted that there were some problems with the broader community, particularly when Woodlands staff became ensnared in the issue of school consolidation. Discussion about consolidation had surfaced periodically since the 1970s and had been pushed by state administrators, but it was not until after a devastating flood in 1985, and Woodlands' subsequent decision to operate an office out of the county seat of Franklin, that they got involved. The question facing the community was whether or not to close the more remote, and "less affluent," schools in the North Fork community. Those residents understandably did not want to give up control of their local schools or have their children bused over curvy mountain roads to the county seat of Franklin, while proponents of consolidation understood that their schools would receive extra funding for

\footnotetext{
${ }^{77}$ John O’Brien, At Home in the Heart of Appalachia (New York: Alfred A. Knopf, 2001), 151-152, 96.
} 
forging ahead with the action. The Taylor-Ides had loosely proposed that the county adopt experimental educational programming to avert consolidation. But a conversation that resulted in the local school superintendent hearing about the proposal via a state senator earlier than he was supposed to sparked hostility and suspicion toward Woodlands. The debate became so heated that even the Washington Post picked up the story. As it reported, on the night of a community meeting "fears and tempers were raised so high that sheriff deputies and state troopers for miles were alerted for possible violence.” So the community was rife with tension over consolidation, but at the same time, Taylor-Ide observed that subsequent debates about economic development that did not involve Woodlands were equally contentious. ${ }^{78}$

Floyd, Virginia, and the Virginia Blue Ridge more broadly, did not experience as much antipoverty work as its coalfield and West Virginian counterparts. Poverty rates in 1980 in Floyd and surrounding counties generally remained in the low-to-mid teens, suggesting that the region in general fared better than Appalachian counties further west. ${ }^{79}$ A community action agency was founded in 1965 that represented Floyd and Montgomery counties, but there has been little evidence to suggest that Floyd or other Blue Ridge communities received the same level of attention from antipoverty workers in the 1960s or 1970 s. ${ }^{80}$ Any local animosity directed toward homesteaders and communitarians in Floyd for their attempts to involve themselves in the community had more to do with the dynamics that came from conflicting visions about planning and development than about the alter-natives' hopes to alleviate or uplift the mountain poor. Journalist Seth Williamson captured the spirit of the Floydian alter-natives' hands-off approach

\footnotetext{
${ }^{78}$ Jennifer Taylor-Ide, interview by author, Morgantown, WV, February 28, 2011; Mary Jordan, “School 'Reform': Promise or Threat?” Washington Post, February 14, 1992.

${ }^{79}$ Appalachian Regional Commission, “Poverty Rates, 1980: Appalachian Virginia,” Appalachian Regional Commission, "Poverty http://www.arc.gov/reports/region_report.asp?FIPS=51999\&REPORT_ID=13 (accessed July 15, 2012)

${ }^{80}$ New River Community Action, “New River Community Action Home Page,” New River Community Action, http://www.swva.net/nrca/ (accessed August 29, 2012).
} 
to politics when he commented that in spite of "what their past politics may have been" in the 1960s, they are "content to live in peace without attempting to convert their neighbors." According to a local farmer, the fact that they remained relatively quiet in the earliest years of the migration might have helped smooth the transition: “"At first when the hippies started to come in I'll admit we was a little leery of 'em. This has always been a nice place to live and we didn’t want no demonstrations or to have them growin’ heroin or marijuana all over the place. But most of 'em seem to be pretty quiet folks, and steady. So I say if they don't bother nobody else, we got no call to bother them.",81

Alter-natives’ Impressions of Appalachians:

While there may have been significant buzzing among locals in regional communities during the early years of the back-to-the-land movement, the in-migrants had their own set of impressions to digest. Many who came to the mountains reveled in the local folk culture and actively participated in community events like festivals and square dances that gave them a sense of connection and belonging to a grounded, traditional culture. Others either remained oblivious to the local culture or felt that the intensity of their homesteading activities left them little time for socialization with the neighbors. Still, almost everyone at one point or another had some level of contact with long-term residents, and as can be expected, their impressions ranged from the positive to the negative and in between. While most alter-natives praised their native neighbors for harboring a "live and let live” attitude (and many natives say the same thing about their own culture), they also had to occasionally navigate narrow-mindedness, conventionalism, racism,

${ }^{81}$ Seth Williamson, “The New Pilgrims of Floyd County,” The Roanoker, April 1981, 26. 
and other parochial attitudes. Some openly challenged these attitudes, particularly when they conflicted with the in-migrants' notions of liberty, equality, and fairness, while others curbed their own countercultural expressions to varying extents just to get along.

Most alter-natives interviewed for this project had many positive things to say about the local population. They typically commented on the region's friendliness, openness, and tolerance in spite of having caught wind of occasional rumors or having been involved in confrontations. Writing to the Floyd Press in 1977, Richard Creasy commented on the "trusting" nature of the local population and the "understanding and caring" that he and his family had "never experienced” during their "city dwelling years." 82 "The feeling of the mountains and the friendly people are very inspirational," remarked Floydian artist Judy Cox. ${ }^{83}$ Another artist, Jayn Avery, found that most people held the attitude of “Live and let live ... You don’t bother me, I don't bother you. ${ }^{\circledR 4}$ Lincoln County alter-native Ann Farewell touted both the area’s beauty and the warmth of the residents in an interview with the local newspaper: "The people in West Virginia are just amazing, they're all friendly." ${ }^{85}$ Alter-natives in other locations likewise cited Appalachians' openness and "live and let live" attitude. One Asheville, North Carolina, alternative who came to the region in the 1970s remarked to a newspaper, “There's a tradition among the mountain people to live and let live.” The man was impressed by the fact that natives of the area had been more tolerant of his homosexuality than people in northern cities. ${ }^{86}$

\footnotetext{
${ }^{82}$ Mr. and Mrs. Richard Creasy and Children, "Letters to the Editor,” Floyd Press, June 9, 1977.

${ }^{83}$ Wanda Combs, “Artists Find County A Place of Inspiration,” Floyd Press, May 25, 1978.

${ }^{84}$ Avery interview.

${ }^{85}$ Tommy Galloway, “Anne Farewell Prefers to Paint Stained Glass,” Lincoln Journal, December 25, 1974. In an earlier letter to the editor of the Lincoln Journal, Ann Farewell spelled her name without an 'e.' It appears that this article had her name spelled incorrectly.

${ }^{86}$ Gene Sloan, "High-Country Hip: Nightlife and Art Scene Make Asheville, N.C., the Most Happening Town in the Blue Ridge,” USA Today, October 3, 2003.
} 
There were other impressions, some neutral and some negative, that shaped early relationships between alter-natives and locals. Several alter-natives felt that moving into rural Appalachia was akin to moving back in time. A'Court Bason, who was a teenager when his mother and sibling established Travianna on the Vests' former property, described his move from Raleigh, North Carolina, as having been akin to "time travel." "When we moved here," he said, “I knew ... that I had just moved twenty years back in time.” He remembered that on his bus to school, his "bus driver once asked, how many kids had ever been to the ocean.” Only "one of them had," he claimed. When she asked how many had been to Roanoke, forty miles to the northeast of Floyd, "only five or six” had ever been. "They were twenty years behind the game," he concluded. Even "the colloquialisms were twenty years old. They still thought calling something 'stout' was cool ... So it was in the seventies, but we moved into the fifties." ${ }^{87}$

Accents, limited worldviews, and some rather extreme examples of primitive living shocked other alter-natives. Joanie Goldsmith remembered meeting two gentlemen who lived way up a holler in Lincoln County after they “showed up on our property on a mule." "I couldn’t even understand them," she admitted, because "their accents and their colloquialisms and everything were so back woods and backwards.” The men "had never been in a car, they had never had running water, they had never been to school. They were almost like cave men," she concluded. Goldsmith conceded that not everyone in the county lived that way, but there were “neighbors, a lot of them,” whose “kids dropped out of school early and really didn’t have any idea about the outside world." She continued to describe the primitive conditions she found in her community, comparing her own experiment with self-sufficiency to their lifestyle:

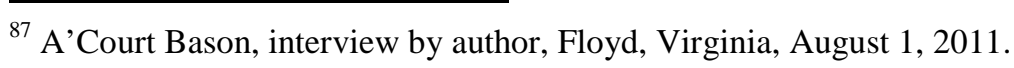


One of our nearest neighbors, he didn't have electricity or any kind of plumbing. They had an outhouse. We all had outhouses but, we actually had a toilet that was usable in the summer, but there were different degrees of primitive living. Those two guys were really the most primitive I ever saw. But there were these hollers that go off of other hollers and the further back you got the more primitive it became. It's hard to describe. They just had less and less knowledge or wanting to know about the outside world. They didn't watch the news, they didn't read newspapers, a lot of them. Not all, but some of the people. ${ }^{88}$

"Karen Martin,” who initially settled in Giles County, Virginia, before making her way to Floyd in the 1990s, recalled the experience of coming to Appalachia as "total culture shock." She shared a holler with several old-timers who had never, or only rarely, been off the mountain. One was an old man who had "never in his whole life ... been outside this little holler.” For entertainment, "He listened to a country music station" on an old "radio that had all kinds of flashy lights and stuff and a black dial.” But he had never seen television until somebody gave him a TV as a gift. After watching it for about a day, "he threw it out of his house" because "it scared the begeebers out of him. Cause it was this whole huge outside world that he could not even begin to visualize. It was so threatening to him to see” shows like soap operas and sitcoms that were popular in the late 1970s and early 80s. Another elderly couple in the holler, claimed Martin, lived without electricity or cars.

You could only walk up to [their] house, and [the wife] sold eggs. I used to walk up there and buy eggs from her. She didn’t have any refrigerator. The eggs all just sat in a big

\footnotetext{
${ }^{88}$ Goldsmith interview.
} 
bowl on the table. And you never knew how old they were. You just learned to crack each one in a bowl before you used it. Cause there might be a rotten one in there. But mostly they were fine. She did every once in a while get the bowl and dig it out if enough people came up and bought eggs. She'd give them to her dogs or something. And she'd never been off that mountain, hardly. She was like the matriarch of this whole big clan of people round there, and so she had her kids and grandkids and everybody came up and visited. Actually, both of them, the couple was both alive, and they were ancient. The guy had a big white horse. Years later I had a big white horse and it reminded me of him. He never had a car. They never had a car.

People like this, she claimed, were not exceptional at the time. There were still a number of people "like that that were living all the old ways." 89

Gender relations in mountain communities could be particularly confusing, and sometimes troubling, for liberated in-migrants. The oral histories that contain comparisons between gender dynamics in the local community and the alternative community, or the interviewee's own experiences on a homestead or in a commune, sometimes exposed a range of ambivalences regarding home-based labor, attitudes about women's liberation, and the rejection of mainstream values. ${ }^{90}$ Ironically, homesteading women interlaced their impressions of cultural backwardness with remarks about gender relations while they still celebrated their own roles in creating domestic havens from mainstream society. In some cases, these ambivalences were present well before their move to the mountains. While Goldsmith recalled that Heathcote commune in Maryland had been relatively balanced in terms of gender equality, she admitted

\footnotetext{
89 "Karen Martin,” interview by author, Floyd, Virginia, September 26, 2011.

${ }^{90}$ This will be explored at length in a chapter to be added for publication.
} 
that others had struggled with the issue as the women's liberation movement unfolded. But in Lincoln County, "They were in the fifties still as far as men go to work, women stay home, raise the children, do the canning and all that stuff." Goldsmith also insisted that she felt comfortable with engaging in traditional women's work like cooking and canning. "I like to cook and I love to can,” she admitted, “and maybe that's a woman thing but I do that.” But, she added, she also "helped build houses and ... chopped a ton of wood, especially after" she and her husband separated." ${ }^{91}$

Although Karen Martin acknowledged that women in Giles County went to work, she still found their primary focus on domestic duties troubling: "The liberated women in Giles County were the ones that went to a factory job and came home and took care of the house and kids." "I say that sarcastic," she added, "but they were just, oh, awful. I was never so lonely in my life.” Rather than finding any deep friendships with native women, she connected with two other non-natives, one from New York City and the other from Switzerland, for company. But given her perception of rigid gender roles in her community that left her feeling alienated from local women, it is somewhat surprising that she found an unlikely role model in Appalachian musician and actress Dolly Parton. "Given where she came from, she’s incredibly smart. She’s brilliant. And I don't know where she got that ability to stand up for herself so well. I think maybe a bunch of kids in her family maybe to stand out or something? I don't know. But she apparently had it from the time she was a very little girl. Anyway, she was about my only heroine there in Giles County." ${ }^{92}$

\footnotetext{
${ }^{91}$ Goldsmith interview.

${ }^{92}$ Karen Martin interview.
} 
Other alter-natives found it strange that the genders sometimes remained socially segregated. Maggie Hennessey admitted that she had been rather ignorant about social norms in her exchanges with local men when she first moved to Lincoln County. She had been raised in a large family with several brothers, so she was accustomed to speaking to men in the same manner as women. But in Lincoln County, she claimed, the community norms were different: unmarried or unrelated men and women were not to speak to each other outside of large group settings. "I always feel comfortable around men," she asserted. "It's not cause I'm a flirt. It's not sexual." But "here, when we met some young people here, some locals ... I would feel comfortable with talking with the guy by myself, and the wife was so uncomfortable. And it took me a long time to catch on what was going on. I wasn't supposed to talk to him. I was only supposed to visit with her and not have anything to do with him ... and that's even with the young people." ${ }^{93}$ Floydian alter-native Ed Gralla, who conceded that through the years he maintained a predominately business, rather than personal, relationship with locals, nonetheless recalled having been surprised by how "shy" local men were toward women. "When we moved here,” he said, "the men would not talk to my wife generally, mechanics and other people.” This shocked them, because in New York they had "traveled pretty much as equals" and understood that "everybody could communicate with everybody." He remembered that it had taken them “the greater part of a year to realize that these guys were so shy. They just couldn't talk to a woman in the same way."94 And Greg and Verena Sava, who homesteaded in Nicholas County, West Virginia, likewise found the custom of visiting with people of one's own gender to be foreign. Verena recalled, "We would sit [with] the women in the living room, and the guys were all outside sitting on stumps and stuff." She "couldn't imagine” why they did not visit together,

\footnotetext{
${ }^{93}$ Hennessey interview.

${ }^{94}$ Ed Gralla, interview by author, Floyd, Virginia, August 4, 2011.
} 
"but that's the way that the women visited—in one place," and at the time they did not have their kitchen completed, so the women remained in the living room while the men socialized outside. When she asked her neighbors about the custom, "they were very surprised because that's the way you visited, apparently.,95

As much as some men and women struggled to understand what at least initially appeared to be feminine subservience in Appalachian communities, they also had their own broad range of outlooks, worldviews, perceptions, and challenges to navigate. Their impressions reveal a great deal about American society's perceptions of rural culture in general—-that it was backward, that women were typically viewed as subordinate to men, and so on—and Appalachia in particular. To be sure, these perceptions were grounded in reality to some degree, but they also limit understanding of the complexity of gender relations in Appalachia. While women were often expected to put family first, many worked, and there are countless examples of women who emerged as community or religious leaders, union organizers, environmental activists, and more. Still, notions of traditional gendered divisions of labor and propriety between the sexes persisted, particularly in communities like Floyd and Lincoln that maintained strong religious traditions. In reading between the lines of the above impressions, one can see that Appalachian women in the 1970s were, like women elsewhere, faced with difficult decisions about navigating the demands of homelife and economic need. Women like the factory workers in Giles County, and even Wanda Vest in Floyd, may have felt pressured at times to enter the workforce while still feeling compelled by duty to remain at home, raise children, and care for their husbands. Vest's husband, after all, sold the property after having worked himself so hard that he was admitted to a hospital. So alter-native women’s understanding of Appalachian women’s subordination and

\footnotetext{
${ }^{95}$ Greg and Verena Sava, interview by author, Nicholas County, West Virginia, May 20, 2011.
} 
passivity is likely as much a reflection of their own misunderstandings that stem from experiences grounded in social class, education level, and urban upbringings as it was a reflection of any rigid or persistent social customs that shaped regional community interaction. ${ }^{96}$

Issues related to race were equally complex and were probably more likely to spark conflict between some locals and socially-conscious alter-natives who had identified or sympathized with the civil rights movement. Before analyzing the in-migrants' reactions to racism in Appalachian communities, it should be noted that among the other myths about Appalachians that back-to-the-landers may have carried with them into the mountains, there also existed the conventional understanding that the region's white residents were relatively innocent of the racism and hatred that plagued the rest of the South. John Alexander Williams suggests that this myth likely helped to direct the warmer climate-seeking back-to-the-landers into the mountains rather than lowland southern communities. ${ }^{97}$ The notion of Appalachian innocence has been so pervasive that, as sociologists Larry Griffith and Ashley Thompson contend, Appalachian scholars have had the freedom "to help [mountain whites] achieve 'selfdetermination"” in a way that would have been completely unacceptable for scholars or activists laboring in Dixie. The perception of mountain whites' racial innocence was rooted in part in

\footnotetext{
${ }^{96}$ Scholarship on Appalachian women’s community involvement and its ties to gender relations is sorely lacking, but there are a few studies that shed light on the issue. It should be noted that while mountain women were generally expected to care for children and home, many engaged in public work and became active leaders in their churches, communities, and places of work. For more information on women's involvement in Baptist Churches and revivals, see Deborah Vansau McCauley, Appalachian Mountain Religion: A History (Urbana: University of Illinois Press, 1995), 221; for personal stories of mountain women's struggle and resistance, see Kathy Kahn, Hillbilly Women (Garden City, NY: Doubleday and Company, 1973); for an analysis of broad issues that have affected southern women in general during the $20^{\text {th }}$ century, see Melissa Walker et al., Southern Women at the Millennium: A Historical Perspective (Columbia: University of Missouri Press, 2003); for an exploration of women’s leadership and involvement in labor struggles in northeast Tennessee, see Jacquelyn Dowd Hall, "Disorderly Women: Gender and Labor Militancy in the Appalachian South,” Journal of American History 73 (September 1986), 354-382; and for deeper discussion of applying feminist analysis to Appalachian Studies and vice versa, see Elizabeth S.D. Engelhardt's introduction to Beyond Hill and Hollow: Original Readings in Appalachian Women's Studies (Athens: Ohio University Press, 2005).

${ }^{97}$ John Alexander Williams, Appalachia: A History (Chapel Hill: University of North Carolina Press, 2000), 353; See also, John C. Inscoe, ed., Appalachians and Race: The Mountain South from Slavery to Segregation (Lexington: University Press of Kentucky, 2001), 1-2.
} 
resistance to the Civil War (some areas resisted while other areas fought for the Confederacy), and northern whites' hopes for "sectional reconciliation" afterward. Although somewhat flawed, they provide evidence suggesting that Appalachians in the central and southern mountains may identify themselves as southern more frequently than their lowland counterparts and may even have a tendency to exhibit more "Neo-Confederate" sympathies. In Virginia, for example, they find that $83.3 \%$ of those living in Appalachian counties identified themselves as southern, whereas only $61.1 \%$ of lowland Virginians did. ${ }^{98}$ In West Virginia, the rates were lower, but since the entire state is contained within the Appalachian mountains, highland / lowland comparisons are impossible. Still, nearly one third of West Virginians considered themselves to be southern. Their more damning evidence suggests that mountain whites were more likely to believe that the south would have been better off had it won the Civil War and that they were "less likely to favor unqualified racial integration" than lowlanders. "Insofar as attitudes such as these illuminate important aspects of collective identity,” Griffin and Thompson conclude, "then, whites from the Appalachian South seem overwhelmingly to express ... a Southern identity and, at least as frequently as do lowland Southern whites, voice understandings that affirm 'whiteness' and its role in the region's racial history and symbols." ${ }^{99}$ The problem with the survey, however, is that it failed to control for race among its informants, so clearly more research needs to be conducted on the subject. Still, it highlights the presence of pro-Confederate attitudes in the upland south and complicates the notion that people living in Appalachia identify themselves as Appalachians instead of simply as southern.

\footnotetext{
${ }^{98}$ This was based on the Appalachian Regional Commission's definition of Appalachia. Griffin and Thompson also offer statistics based on the 1962 Thomas Ford and Rupert Vance survey. In that case, the statistics are just as telling: $78.2 \%$ to $60.2 \%$, respectively.

${ }^{99}$ Larry J. Griffin and Ashley B. Thompson, "Appalachia and the South: Collective Memory, Identity, and Representation,” Appalachian Journal 29 (Spring 2002): 309-312.
} 
As of the 1960 census, both Floyd and Lincoln Counties had very low African American populations. Floyd reported 307 African Americans, not quite three percent of the county's population, while Lincoln had only three. ${ }^{100}$ Like many southern counties, Floyd saw its fair share of racial struggles. The county school board ultimately decided to integrate in 1959, however, rather than close the school, as had several other county education systems. In fact, it graduated only the second African American in the entire state following the Brown v. Board decision. But the school system still resisted to the point that the student's family spent months in court. The closest African American school had been the Christiansburg Institute, a school founded by the Freedmen's Bureau in 1866, and the black families fought continued segregation in county schools in part due to the long distance their children had to travel to get to Christiansburg. ${ }^{101}$ In Lincoln County, with a population of African Americans so small and with a state government that generally cooperated with the federal mandate to desegregate, the issue of desegregation was less salient. However, in 1974, as neighboring Kanawha County exploded in controversy over new Language Arts textbooks that employed materials from Malcolm X and others, a number of Lincoln Countians became involved. Their involvement exposed locals’ concerns about incorporating multiracial textbooks into the schools' curriculum and embracing "secular humanism." The cast of characters in the protests, which drew from a number of surrounding counties and even states like Ohio, suggests that racism at least in part fueled the conflict, although that is not the full extent of the story. The county paper does not clearly state the exact number of people from Lincoln County who joined protests against the educational

\footnotetext{
${ }^{100}$ University of Virginia Library, “Historical Census Browser for Virginia and West Virginia," University of Virginia Library, http://mapserver.lib.virginia.edu/ (accessed August 6, 2012).

${ }^{101}$ Anna L. Mallory, “' “It didn’t seem fair': Floyd's first black graduate to miss $50^{\text {th }}$ reunion,” The Roanoke Times, August 7, 2010, under "Daisy Penn," http://www.roanoke.com/news/nrv/wb/256195, accessed August 6, 2012.
} 
materials, but it does suggest that there were at least eight who attended an October 1974 protest and possibly as many as three hundred who at least tacitly supported the protests. ${ }^{102}$

Several alter-natives reported experiencing local racism in conversation, either directly or by overhearing racial slurs. Some chose not to voice their disapproval for fear of disrupting the new relationships that they were trying to build. Joanie Goldsmith recalled hearing the word “nigger” frequently in conversations with locals. She ultimately decided not to challenge them, however, because she understood that the county was "conservative” and was part of "the south.” Karen Martin admitted that she was initially surprised that people in the community avoided discussing difficult issues such as race or religion. "Nobody would actually come up and say anything that had any sort of emotional, political, religious charge to it.” And after "living in San Francisco and stuff, I thought these were the most beat around the bush people I had ever met in my life. I was just really craving some more up front people who would tell you how they actually felt about everything.” But she learned from another alter-native in Floyd that "you might be living next to these people for the rest of your life, so you don't really want to say anything to put you on bad footing or that's going to make you uncomfortable to be neighbors.” Although she witnessed racist attitudes in the community, she speculated that this type of thing was part of the reason why locals were by and large "very reticent to express themselves." 103

Others were less willing to tolerate racism. Tom Harward, who moved to Barbour County, West Virginia, to work as a physician’s assistant, had a large interracial family. While

\footnotetext{
102 “Some here did attend textbook rally Oct. 6," Lincoln Journal, October 23, 1974; Carol Mason, “From Textbooks to Tea Parties: An Appalachian Antecedent of Anti-Obama Rebellion,” West Virginia History: A Journal of Regional Studies Vol. 5, no. 2 (Fall 2011): 9. Carol Mason finds archival records indicating that "some arguments against the books were issued from neo-Nazis bemoaning purported Jewish-controlled publishing, some from racists who wanted the 'nigger books out,' some presuming the books were pushing communism and pornography, some calling for parental rights to oust ineffective school officials, some fearful of Satan, [and] others still suggesting that the books portended a new threat called humanism." See also Carol Mason, Reading Appalachia from Left to Right: Conservatives and the 1974 Kanawha Textbook Controversy (Ithaca, NY: Cornell University Press, 2009).

103 Karen Martin interview.
} 
working at his practice he occasionally encountered racism, and when this happened, he quickly let the individuals know that he would not tolerate those types of attitudes. On a few occasions, Harward severed ties with certain individuals who would not curb their racist rhetoric. Maggie Hennessey, who also worked as a medical professional, likewise refused to tolerate that behavior from her coworkers. She recalled hearing about "this place over in West Hamlin that they...[called] ' $N$ ' word Ridge ... and they were talking about it one day. The name has [since] been changed. So they've advanced some. But they were talking about it, and the nurse was using the old name. And I looked at her and said, 'Don’t you use that word in front of me."” "I can't handle” hearing the " ' $n$ ' word,” she explained in an aside. The woman who had used the old name of the Ridge explained to Hennessey, "well, that's what we call it.'” And Hennessey replied, “ ‘Well I don’t care. Don't say that word in front of me.”” The woman then "backed off." 104

Through these impressions we see how different alter-natives responded to some of the early challenges of living in rural areas. First impressions typically changed as the newcomers came to know their native neighbors on different levels, some for the better and some for the worse. Hennessey declared that could she revisit the past, she would not choose Lincoln County as her home partly because of those instances of narrow-mindedness described above. She also felt that the area was not particularly well suited for the kind of farming that she wanted to be able to do. ${ }^{105}$ Others, in spite of those moments when they witnessed racism, intolerance, or conservative attitudes toward women, still declared that they found the culture generally open and inviting.

\footnotetext{
${ }^{104}$ Hennessey interview.

${ }^{105}$ Hennessey interview.
} 
Connecting with the neighbors:

Early impressions and even conflict between some newcomers and old-timers should not diminish the strong relationships that alter-natives cultivated with their mountain patrons. Both parties had their own initial perceptions, concerns, and adjustments to navigate, but at least between the newcomers and their elderly native neighbors, those barriers eventually broke down. Nearly every person interviewed for this project recalls having had at least one local old-timer who provided them with unsolicited assistance, offered them guidance on any variety of tasks related to farm labor, imparted knowledge about local traditions or the natural environment, and helped them to become acquainted with the rest of the community. Connecting with neighbors was an integral part of becoming integrated into the community. People like Henry Baker in Lincoln County and Wanda Vest in Floyd helped to promote acceptance by dispelling myths and rumors and by providing the newcomers with social and economic opportunities.

Before discussing relationships between the old-timers and young agrarians, however, it is important to note that the dynamic between the in-migrants and locals of their own age was not always as warm. Several alter-natives commented on this dynamic, attributing it to a clash in values that came from competing rural and urban or class-based worldviews. They wanted to reject consumer culture while the local young adults, many of whom had been raised without the luxuries of the middle class, embraced it and aspired to rise in economic status. Avery speculated that young adults in Floyd associated rural living with poverty:

The ones that, the neighbors that were our age, our peers, couldn't relate to us at all, because, ‘Why would you want to can?’ They grew up canning. They didn’t want to can 
anymore. They didn’t want to do any of that anymore because they related it to poverty. And they related it to feeling bad about themselves. And that's something that took me a while to learn. That the rural culture included a real state of mind of ... 'Is there something a little stupid about you? You're a redneck. Dumb redneck.'

She added that although members of her own age cohort are now cordial to the alter-natives, they remain socially segregated. Joanie Goldsmith observed the same thing in Lincoln County: "The older the people the more we were accepted. It was interesting. Whereas a lot of the younger twenty and thirty something people had been raised in poverty and were trying to become more middle class / mainstream and they were more cautious about us. They didn't understand why we were giving up our middle class and going back-to-the-land and living in a more primitive way.” ${ }^{106}$ Vietnam veterans also appeared in alter-natives’ recollections of their own age cohort. Sometimes they too sought out a "laid back" lifestyle, according to John Salstrom, so the two groups occasionally partied together. But there were also those veterans who suffered from Post Traumatic Stress Disorder and could be “very aggressive.” One, John recalled, “almost put a knife through [him].” He was just not into what us hippies were doing and probably thought we were all anti-war and, which most of us were.”107

According to several alter-natives, the old-timers, many of whom had lost children to outmigration, were flattered and proud to have young people take interest in their traditions and knowledge. In a collective oral history, Jayn Avery, Colleen Redman, and Fred First, all Floydian in-migrants, analyzed and described their experiences with mountain patrons. They believed that part of the reason why old-timers had accepted them was because the local children

\footnotetext{
${ }^{106}$ Goldsmith interview.

${ }^{107}$ Salstrom interview.
} 
had not. "Their kids wanted to go to Wal Mart," explained Jayn Avery, "and become upgraded in the American culture.” ${ }^{108}$ The back-to-the-landers, however, demonstrated deep interest in traditional folkways, and the old-timers were happy to share their knowledge. "There was one family on the road that just loved the new people coming in because they recognized our wanting to live on the land." The farmer "would come over and talk to my husband who was raising the goats and taking care of them, and they would talk farmer talk and just loved it. And you could tell that he and his wife were so proud that there was a young couple over there that were into canning and gardening." "We were honoring the way they grew up," she added. "We wanted to know more about how they did it here. And so we asked them questions about the farming and the land and the trees and the chestnuts and whatever happened there. And so we were way more interested in their lifestyle and their living” than some of their own children. Colleen Redman agreed. “I just can’t think of any negative experiences I had with an old-timer,” she said. “Walk and show me ginseng, things like that. And so maybe that was going on, that they were impressed that we cared, and they could pass on what they knew to us."109

Fred First described one of his early back-to-the-land experiences with a native neighbor in Wytheville, Virginia, where he moved prior to coming to Floyd. His story illustrates the type of quiet assistance that newcomers received. The man "was uneducated" but was "one of the smartest, wisest people” First said he had ever known. The man lived across the street from First, who "had moved from Birmingham to Wytheville. Didn’t know nothin', ' he admitted. “We froze to death the first spring we were here, even at seventeen cents a gallon, we couldn’t burn it fast enough to keep the house warm.” His neighbor advised First to purchase a wood stove,

\footnotetext{
${ }^{108}$ Several alter-natives in Floyd, Lincoln, and other communities have also indicated that they initially struggled to connect with locals of their own age group. See Avery interview and John Salstrom interview.

${ }^{109}$ Redman interview.
} 
which forced First to admit that he did not " know how to get my own wood.” So the man took him "under his wing [and] taught [First] how to use a chainsaw. "But," First continued,

he came over one time when we were planting our first garden. We had a whole lot more enthusiasm than we had knowledge about gardening. We knew we wanted to get back to the earth and here we were in the middle of Wytheville, and they said, 'Well, you're right in the middle of town. The noise is going to kill you.' We just laughed. We had just come from Birmingham. So we tore up the yard. Used his rototiller-which I had never used a rototiller - tilled up the yard, and he expected us to plant when everybody else did. But no, we went ahead and put our tomatoes in the ground the first of April because that's when you put them in the ground in Alabama. So he comes over and he sort of stands there and doesn't say anything, just holds his pipe.

'Mm hm. Whatcha doin'?'

'Getting some tomatoes in the ground,' replied First.

'Well they’re gonna die,' said the neighbor.

That's all he said. Turned around and walked off.

Colleen Redman responded to First’s narrative, saying, “Well, he didn’t want to tell you what to do." First agreed, averring that "they were so supportive and our kids looked on them like grandparents, and they taught us so much about so many different things ... there was no animosity or suspicion or hesitancy whatsoever." He believed that the relationships built between the back-to-the-landers and the "people who have deep roots, multi-generational roots" were 
founded upon "general cooperation and sharing, at least on the small, local level.” And, he concluded, "that maybe makes Floyd a little different than a lot of places."110

Others admitted that their native neighbors recognized their lack of skill and knowledge about farming. Greg and Verena Sava, who own a goat dairy in Nicholas County, West Virginia, had the same assessment of both their own ignorance and their neighbors’ willingness to guide them in their homesteading endeavors. “They could recognize how dumb we were,” said Verena. During their first year on the farm, they had planned to cut their firewood with a hand-held bow saw. Realizing that the alter-natives were destined for trouble, the old-timers told them, “'You guys are gonna freeze to death.”’ They then spent a weekend cutting firewood for the neophyte couple. ${ }^{111}$ Lynn Stasick was equally naïve about just how much firewood he would need to survive the winter. "I cut a stack of wood about three feet high, about seven feet long, and about two feet wide and thought that'd last the winter. It got us through a week and a half,” he admitted. He also had to learn from a local how to use a chainsaw: “Kenny Carmen, who’s now dead, those guys, crazy as he was and his brothers were, they helped us tremendously. Helped us cut wood so we wouldn't freeze to death ‘til I learned how to use a chainsaw. Not how to use it. Well, yeah, how to use it! How to sharpen the damn thing. But it's useless if you can't sharpen it."112

Stasick had several mountain patrons in Wetzel County who taught him everything from plowing to identifying plants and herbs. A man named Red Schuman, he recalled, "taught me how to drive a tractor, how to plow, how to harrow, and how to plant.” Another person "took us for a walk one day through the hills and showed us . . . what ginseng looked like, yellowroot

\footnotetext{
${ }^{110}$ First interview.

111 Sava interview.

112 Stasick interview.
} 
looked like, and snake root. Where you could find teaberry, and the different mints and all that. And identifying flowers, and identifying trees." "I learned an awful lot," he concluded. But such lessons could also be mixed with mountain humor, so newcomers like Stasick had to be careful about which pieces of advice to follow. Another one of his patrons, Rex Hemilrick, a man who could "sharpen a scythe so you could shave," had an equally sharp wit and liked to joke with the new arrivals.

He gave me some advice when we were up there and we were going to plant potatoes. He said, 'Now you’ve gotta wrap them in newspaper,' and I said, 'Okay.' And I'd never heard that before, and my grandmother was agrarian. And he said, 'You know why?' And I said, 'No,' and he said, 'To keep the dirt out of their eyes. Waaahh!' So those kinds of things. So you've got to take this with a grain of salt, what they're teaching. Don't plant too close to the carrots, or the onions; it'll make their eyes tear up, and all that stuff. But once they figure they can’t put over on you anymore, then you start getting the honest stuff.

Relationships deepened over time, and intimacy developed between many of the alternatives and their native neighbors. Stasick joked around with Red Shuman's son, Justin Other. (The name Justin Other Shuman speaks volumes about the family's sense of humor). The two played practical jokes on each other, including one time when Justin “nailed” Stasick’s "outhouse door shut, and then he threw the pry bar in through the window." So Stasick had to "climb through the outhouse window in order to get the bar in order to get the door open to get out.” On more serious occasions, patrons provided both advice and solace for the alter-natives. One of Jim Chojnacki’s friends had moved to Lincoln County and subsequently lost his mother, 
who had followed him to the county. Jim and the man dug a grave up on a ridgetop but had to stop when they hit bedrock at about two feet. Word of the tragedy spread throughout the hollar, so "two old timers come walking up out the ridge carrying a case of beer and a case of dynamite. So we drank and blasted and drank and blasted all evening."113

As mentioned at the beginning of this chapter, sociological and anthropological studies of small towns reveal that as populations shift and increasing numbers of newcomers move into a rural area, tensions can mount between the new population and old timers. On a micro level in Appalachia, the two parties were able to put their initial reservations aside and form strong bonds over time. Even though the in-migrants are still—forty some odd years later—not recognized as "natives," they slowly integrated into social and familial networks and, by proxy, the fabric of regional communities. But this process did not occur without some conflict; clashing ideals and worldviews presented problems for each party, as did age differences, economic backgrounds, and more. Patricia Beaver best summed up the dynamic of community integration between "foreigners" and locals in Appalachia by pointing to the ways in which old-timers' lives were enriched and enhanced because of the back-to-the-land migration. They "expected friendship and sharing, particularly since the counterculture folks were indeed curious and interesting. The experiences and diversity they brought with them made them appealing and entertaining, and their insights—-though frequently naïve—-were often useful or at least provocative. They provided spice of life." ${ }^{\prime 14}$ At the same time, many of the alter-natives, having felt deprived of gemeinschaft in their early lives, readily welcomed the reciprocal, neighborly relationships they forged with the locals.

\footnotetext{
${ }^{113}$ Jim Chojnacki, interview by author, Myra, West Virginia, July 2, 2011.

${ }^{114}$ Beaver, 137.
} 
But the old-timers likewise expected deference and conformity to existing social codes. While most people likely kept their opinions to themselves regarding alter-natives' expressions of countercultural values, occasionally, when alter-natives became involved in public debates, tensions bubbled up to the surface. As Beaver explained, countercultural newcomers occasionally became "convenient scapegoat[s] for local tensions, as they were in truth representative of economic changes in the nation that were tearing at the local social fabric. They represented the unsettling cultural changes as children were exposed to drug use in public schools, women moved into the public labor force, unemployment rose, and the economy placed greater strain on the family." ${ }^{\prime 15}$ Indeed, Beaver's insights point to the central causes of much of the conflict between newcomers and locals in regional communities during the back-to-the-land migration: economic changes that left Appalachian communities in dire need of revenue and, in turn, left them vulnerable to outside exploitation by corporations or individuals little interested in preserving the character of the local community or the quality of its environment. While many alter-natives moved to the countryside hoping to retreat from public life, threats to their quality of life led them to become actively engaged in public discussions about development. For new residents in Floyd and Lincoln Counties and elsewhere, their participation in public debates occasionally sparked or exacerbated tension between so-called "outsiders" and "insiders.”

\footnotetext{
${ }^{115}$ Beaver, 137.
} 


\section{Chapter Five}

\section{“Hooray for the Outsiders!”: Grassroots Environmental Activism and Native / Newcomer Relations in Floyd and Lincoln Counties}

On January 29, 1988, Lincoln County, West Virginia, alter-native John Salstrom called a meeting to order in the Hamlin Community Center to discuss whether or not a permit should be approved for a joint mining venture, Black Gold and Mountain Black Diamond (BGMBD), to open a strip mine in the Six Mile Creek area of the county. Debate had been raging over the issue since a Black Gold representative, Delbert Burchett, began going door to door the previous summer to ask people if they were willing to sell their land to the company. By January, tempers had reached fever pitch. It seemed that a line in the community had been drawn between those who wanted the mine for employment and those who were concerned about potential decreases in property values and environmental degradation. Salstrom had hoped that the meeting would foster an "exchange of ideas and information" between the different parties. ${ }^{1}$ Instead, it devolved into a shouting match between mining proponents and opponents, almost coming to fisticuffs as Burchett and local high school principal Jennings Midkiff rushed toward federal mining engineer Jack Spadaro during a disagreement over how the mine might affect the local water supply. ${ }^{2}$ Black Gold’s CEO Sandra Perry, Salstrom, and another woman from the community quickly restrained Burchett and Midkiff. But after the meeting Midkiff told local reporters that he would soon pay a visit to Governor Arch Moore to demand that Spadaro be

\footnotetext{
${ }^{1}$ John Salstrom, interview by author, Lincoln County, West Virginia, December 18, 2008.

${ }^{2}$ Lincoln County's Weekly News Sentinel (also called Lincoln Journal-the titles switched intermittently) reported that the disagreement between Burchett and Spadaro was over the water supply, but in a recorded interview Spadaro indicates that he called Burchett out for having been an outlaw mine operator in eastern Kentucky. This issue will be examined below. Jack Spadaro, interview by author, Richmond, KY, March 12, 2011.
} 
fired. “He’s on the federal payroll,” Midkiff stated. "We're not putting up with this outside stuff. That's all there is to it."3

References to “outside stuff,” or more commonly, “outsiders,” in the county was nothing new; for over a decade a handful of native residents, particularly those in positions of economic or political power, had periodically grumbled about non-natives’ attempts to influence local developments. This complaint was only partially accurate; many of the people speaking out against strip mining were native West Virginians, including Spadaro. ${ }^{4}$ But Lincoln County had at one point hosted a large population of alter-natives, although by the time of the Black Gold battle, the majority had already left. The ones who remained had, by and large, integrated into the community. Few still homesteaded full time; instead, they supplemented gardening with parttime work or worked full time as manual laborers, health care workers, or government agents, sometimes having to commute to nearby Charleston or Huntington. Some had become heavily involved with local issues related to education, economic development, the environment, and social justice, while others remained relatively isolated from the larger community. Salstrom became involved with the anti-strip mining movements in the 1970s and 80s, but his emergence as a leader in the 1980s was, he admitted, more because of the immediate threat that the mine posed to his home and family than because of his “environmental sensibilities.” He regarded himself as the "ultimate NIMBY (not in my back yard)” in the Black Gold battle. ${ }^{5}$ Regardless, his leadership elevated his status in the community and, in turn, made him a primary target for people like Midkiff who viewed the alter-natives’ involvement as threatening.

\footnotetext{
${ }^{3}$ Dan Elman-Roche, “Tempers Flare Over Strip-mine Issue,” Lincoln Journal, February 3, 1988.

${ }^{4}$ Jack Spadaro was born and raised in Fayette County, West Virginia, three counties east of Lincoln. He moved to Lincoln County in the 1970s. Spadaro, interview.

${ }^{5}$ John Salstrom interview.
} 
The collective efforts to stave off surface mining serve as one example of the organizational capabilities of the back-to-the-land population. The emergence of organizations like John Salstrom's Home Place, Inc., founded in response to Black Gold and Mountain Black Diamond, demonstrate that the alter-natives formed strong, supportive sub-communities and utilized the free spaces they had carved out in their local food co-operatives and other community centers in order to wage war against environmental threats. ${ }^{6}$ In a county that had a low tolerance for political dissent, it is somewhat remarkable that Home Place was able to win its campaign against the mining enterprise. The win was likely assisted by the fact that the owners of Black Gold proved to be corrupt. It came at the high price of community polarization, however. The community, and the Salstroms in particular, faced periods of elevated hostility that stemmed from a volatile mix of high unemployment and poverty rates, a lax regulatory atmosphere among state and local politicians, and local elites jealous of their control and protective of their financial interests, particularly mineral rights. But Home Place’s campaign also demonstrated that significant native support existed for pro-environmental causes.

Native/newcomer tensions are common during developmental battles in communities that host large in-migrant populations, although the dichotomy is more complex than is popularly understood. Occasionally newcomers themselves have to navigate competing economic and environmental visions. ${ }^{7}$ Around the same time as the Black Gold battle, Floyd County alter-

\footnotetext{
${ }^{6}$ Sara M. Evans and Harry C. Boyte, Free Spaces: The Sources of Democratic Change in America (New York: Harper and Row, 1986), 17; Stephen Fisher, ed., Fighting Back in Appalachia: Traditions of Resistance and Change (Philadelphia: Temple University Press, 1993), 319. As Sara Evans and Harry Boyd define the phrase, free spaces are "environments" where community members can come together and collectively strategize and implement their vision of a more just society. But as later scholars, including Appalachian sociologist Stephen Fisher, have argued, free spaces can also sometimes act in limiting ways. Free spaces have the potential to foster the democratic ideal and often have provided platforms for advancing progressive agendas, but they have also been used for less progressive purposes such as restricting certain sectors of communities based upon racial, class-based, or gendered lines. Still, the potential is there, he believes, for free spaces to become "the foundation for mass-based social movements."

${ }^{7}$ Kathleen M. Brennan and Christopher A. Cooper, "Rural mountain natives, in-migrants, and the cultural divide," The Social Science Journal 45 (2008): 280-292. For a detailed analysis of the evolution of theories regarding
} 
natives questioned whether to convert an experimental wood fractionation facility into one that recycled chemicals. The plant's founder, Luke Staengl, firmly believed that the shift was an economically viable and environmentally sound option for the plant. Other alter-natives feared for the health and safety of local residents should such a process be allowed. The result was a clash of visions about how the county’s development would reflect the growing newcomer population's environmental sensibilities and the need for local jobs.

The Appalachian alter-natives migrated to the region in large part because of their hope to find peace, health, and close kinship with nature in the rural countryside. They revered the aesthetic beauty of the Appalachian Mountains and sought to live simply by cultivating the land, bartering, and foraging in forests and fields. In some ways their sense of place in their communes and on their homesteads grew to reflect that of the native population, and in spite of early local suspicion that sparked occasional conflict, the ones who remained long-term in their adopted

differences in rural/urban environmental values see Robert Emmet Jones, J. Mark Fly, James Talley, and H. Ken Cordell, “Green Migration into Rural America: The New Frontier of Environmentalism?” Society and Natural Resources 16 (2003): 223-226; L. Fortmann and J. Kusel, "New Voices, Old Beliefs: Forest Environmentalism Among New and Long-Standing Rural Residents,” Rural Sociology 55, no. 2 (1990): 214-232. See also D.J. Blahna, Turnaround Migration and Environmental Conflict in Northern Lower Michigan (PhD diss, University of Michigan, 1985); D.J. Blahna, "Social Bases for Conflict in Areas of Reverse Migration,” in Community and Forestry: Continuities and Sociology of Natural Resources, ed. R.G. Lee, D.R. Field, and W.R. Burch (Boulder, CO: Westview Press, 1990); M.D. Smith and R.S. Krannich, "Culture Clash Revisited: Newcomer and Longer-Term Residents' Attitudes Toward Land Use, Development, and Environmental Issues in Rural Communities in the Rocky Mountain West,” Rural Sociology 65, no. 3 (1999): 396-421. Rural sociologists have long pondered the root causes of native/newcomer tensions, particularly as they relate to conflict over developmental issues in small communities. For years the reigning model was the "culture clash" theory, which pointed to socio-demographic and value-based differences between the two groups. In-migrants' middle-class, urban, and educational backgrounds produced a different set of values than rural dwellers, so those of the former group were "expected to pose a threat to the established native community." Sociologists now challenge this limited view, arguing that it does not predict how those values might change over time after resettlement in rural communities. Newer theories, such as the "new voices" and "gangplank" theories, go further to explain how in-migrants' environmental activism in particular might cause conflict. Louise Fortmann's and Jonathan Kusel's "new voices" theory maintains that rural residents already have environmental sensibilities but are less likely to mobilize against perceived environmental threats than the inmigrants. The newcomers, who lend human capital to environmental campaigns, empower the rural population to act. Collectively, pro-environment natives and newcomers end up challenging "commodity interests [that] have historically held the balance of power in resource-dependent communities." The "gangplank" hypothesis posits that in-migrants to "natural amenity" communities like Floyd view those areas as places of "refuge." As a result, they actively campaign against undesirable forms of development. They "are thought to be more willing to pull up the gangplank (or drawbridge) on any new growth or development that is trying to 'invade' their" rural haven. 
communities bonded with their native neighbors by demonstrating interest in old folkways and traditions that deepened their knowledge of and connection to the land. The bridges that were built between the alter-natives and their immediate neighbors during the 1970s and 80s were founded upon shared interests and reverence for the natural world, although those interests might have been expressed in different ways. This mutual affection for the region's cultural and environmental heritage helped in-migrants to assimilate and become engrained in the local community.

Part of the challenge for in-migrants who settled permanently was figuring out how to preserve the rural quality of their new homelands and protect the environment while acknowledging the area’s desperate need for jobs. Many of them had arrived with "relatively inaccurate illusions,” says one sociologist, “about what the new community and their life within it” would be. ${ }^{8}$ As mentioned in previous chapters, these illusions were sometimes projected upon both the locals and the natural world that surrounded them. They shaped how Appalachian alternatives dealt with threats to the local environment. The region's depressed economy often meant that small communities became "sitting ducks” for environmentally unfriendly industries. ${ }^{9}$ Grassroots environmental initiatives blossomed across Appalachia in response to those threats during the 1970s, 80s, and 90s. The illusions of Appalachian communities as Shangri-Las, as places removed from urban and industrial filth, grime, and corruption, prompted alternative inmigrants to move to the region. When they realized that a multitude of threats to their quality of life existed, they felt compelled to become involved with initiatives to keep those threats at bay.

The case studies presented in this chapter shed light on the complex issues related to newcomer involvement in developmental debates in rural Appalachia. Examining the two

\footnotetext{
${ }^{8}$ Patrick C. Jobes, Moving Nearer to Heaven: The Illusions and Disillusions of Migrants to Scenic Rural Places (Westport, Connecticut: Praeger, 2000), 18.

${ }^{9}$ Kamala Bauer, interview by author, Floyd, Virginia, August 1, 2011.
} 
grassroots campaigns—-Home Place and Floyd Environmental Action Team, which organized against the proposed chemical recycling—complicate existing notions of small town resistance to change while assessing the impact that the back-to-the-land movement has had over time in regional communities. Homesteaders and communitarians who remained in the region long-term contributed human capital to their communities, energizing or initiating local movements to improve or preserve the quality of life. Long-term residents' acceptance of this involvement varied depending on the general context in which the issue arose. The local power structures, as well as a bevy of economic and political forces emanating from state, national, and international trends, shaped the activists' campaigns and chances of success. Remarkably, both were successful, and they owed their achievements to both alter-native and native leadership in the grassroots efforts. Hence, this chapter also supports existing sociological studies that highlight increased environmental sensibilities among rural populations in general during the late $20^{\text {th }}$ century.

Newcomer Involvement in Grassroots Environmental Campaigns

The Appalachian alter-natives migrated to the region in large part because of their hope to find peace, health, and close kinship with nature in the rural countryside. They revered the aesthetic beauty of the Appalachian Mountains and sought to live simply by cultivating the land, bartering, and foraging in forests and fields. In some ways their sense of place in their communes and on their homesteads grew to reflect that of the native population, and in spite of early local suspicion that sparked occasional conflict, the ones who remained long-term in their adopted communities bonded with their native neighbors by demonstrating interest in old folkways and traditions that deepened their knowledge of and connection to the land. The bridges that were 
built between the alter-natives and their immediate neighbors during the 1970s and 80s were founded upon shared interests and reverence for the natural world, although those interests might have been expressed in different ways. This mutual affection for the region's cultural and environmental heritage helped in-migrants to assimilate and become engrained in the local community.

Part of the challenge for in-migrants who settled permanently was figuring out how to preserve the rural quality of their new homelands and protect the environment while acknowledging the area’s desperate need for jobs. Many of them had arrived with "relatively inaccurate illusions," says one sociologist, "about what the new community and their life within it" would be. ${ }^{10}$ As mentioned in previous chapters, these illusions were sometimes projected upon both the locals and the natural world that surrounded them. They shaped how Appalachian alter-natives dealt with threats to the local environment. The region's depressed economy often meant that small communities became "sitting ducks" for environmentally unfriendly industries. ${ }^{11}$ Grassroots environmental initiatives blossomed across Appalachia in response to those threats during the 1970s, 80s, and 90s. The illusions of Appalachian communities as Shangri-Las, as places removed from urban and industrial filth, grime, and corruption, prompted alternative in-migrants to move to the region. When they realized that a multitude of threats to their quality of life existed, they felt compelled to become involved with initiatives to keep those threats at bay.

Save Our Mountains and Home Place: The Fight Against Strip Mining in Lincoln County

\footnotetext{
${ }^{10}$ Patrick C. Jobes, Moving Nearer to Heaven: The Illusions and Disillusions of Migrants to Scenic Rural Places (Westport, Connecticut: Praeger, 2000), 18.

${ }^{11}$ Bauer interview.
} 
Lincoln County is located in the southwestern quadrant of West Virginia, just one county over from where the Mountain State meets the Ohio and Kentucky lines. Although southern West Virginia is home to the state's heaviest coal producing counties, Lincoln has traditionally seen very little mining activity as compared to its neighbors Boone, Logan, and Mingo counties. ${ }^{12}$ In fact, by 1969, the county had no coal mines, surface or underground. ${ }^{13}$ Because of the absence of surface mines and pressure from anti-strip mining groups, in 1971 state lawmakers included Lincoln County in a moratorium created to prevent any from opening in counties that had never been strip mined. The law was not permanent; it came under review every two years and fell under pressure from the coal industry and some state politicians. Still, the moratorium was renewed in 1973, just as the homesteader migration was picking up steam in Lincoln County. ${ }^{14}$

Surface mining as a practice grew after World War II as technology advanced. The creation of massive draglines coupled with the escalating size of heavy machinery and trucks made surface mining an increasingly efficient form of extraction. ${ }^{15}$ Although West Virginia had imposed legislation to regulate surface mines in 1941, the state did little to enforce those laws, and amendments further weakened them in the 1960s. In response, a coalition of native residents and antipoverty workers began to protest, with some arguing for a complete ban and others for

\footnotetext{
${ }^{12}$ For statistics related to the development of mining in southern West Virginia, see West Virginia Department of Mines, Annual Report of the Department of Mines for the Fiscal Year Ending June 30, 1920 (Charleston: Tribune Print Co., 1920), 121; West Virginia Department of Mines, Annual Report of the Department of Mines for the Fiscal Year Ending June 30, 1930 (Charleston: Tribune Print Co., 1930), 88.

${ }^{13}$ West Virginia Department of Mines, Annual Report of the Department of Mines, 1970 (Charleston: Tribune Print Co., 1970), 12-13.

${ }^{14}$ The moratorium included twenty-one other counties. "Group in Lincoln County Fighting Against Strip Mining by Appalachian Power Co,” Lincoln Journal, August 7, 1974; Penny Loeb, Moving Mountains: How One Woman and Her Community Won Justice from Big Coal (Lexington: University Press of Kentucky, 2007), 55.

${ }^{15}$ Chad Montrie, To Save the Land and People: A History of Opposition to Surface Coal Mining in Appalachia (Chapel Hill: The University of North Carolina Press, 2003), 24.
} 
tighter regulation. ${ }^{16}$ Similar circumstances occurred in other eastern coal producing states, so that between the late 1960s and mid-1970s, a number of opposition groups formed in the central Appalachian coalfields. ${ }^{17}$ Widespread attention to the issue prompted the passage in West Virginia of one of the strictest control laws in Appalachia, although regulation remained lax. ${ }^{18}$ Grassroots opposition to surface mining in West Virginia shaped state politics during the first half of the 1970s. During the 1972 elections, candidates who opposed strip mining defeated those backed by industry. In the gubernatorial primaries, John “Jay” Rockefeller IV, who was against surface mining at the time, bested other Democratic candidates with ties to coal, although he lost to Arch Moore in the general election. In Kanawha County, where the state capital of Charleston is located, eleven strip mining opponents were nominated "for the county’s fourteen seats in the House of Delegates, including eight Democrats and three Republicans.” In Raleigh and Wyoming Counties, another surface mine critic, Warren McGraw, defeated Tracy Hilton in the state Senate race. The issue was so prominent that federal mining engineer Jack Spadaro recalled a state legislative session from that era that "fell one vote shy of abolishing" the practice. $^{19}$

The region-wide flurry of activity to end strip mining peaked in 1972, when the nascent environmental movement was energized, activist groups were most organized, and the national energy crisis had not yet occurred. Because many of the organizations had little success obtaining state-level support for abolition bills, and because state court rulings so often favored

\footnotetext{
${ }^{16}$ Montrie, 112-113.

${ }^{17}$ Organizations included Save Our Mountains, Save Our Cumberland Mountains (TN), Appalachian Group to Save the Land and People (KY), and the West Virginia-based Citizens for the Abolition of Strip Mining, an organization funded by Jay Rockefeller. Even the relatively conservative Council of the Southern Mountains spoke out against strip mining in the 1970s. Montrie, 101-104, 115, 125; Kiffmeyer, 19; Bill Allen, "Save Our Cumberland Mountains: Growth and Change Within a Grassroots Organization,” in Fighting Back in Appalachia: Traditions of Resistance and Change, ed. Stephen L. Fisher (Philadelphia: Temple University Press, 1993), 86.

${ }^{18}$ Montrie, 114.

${ }^{19}$ Rockefeller believed that his position against strip mining cost him the 1972 election. After the election, Rockefeller began defending surface mining. Montrie, 125; Spadaro, interview.
} 
coal operators, activists focused their efforts on the federal government. The first significant hearings on federal strip mining legislation came in 1968, but it wasn't until 1971, when Congressman Ken Hechler introduced H.R. 4556, that discussion of phasing out strip mining truly began. Hechler's arguments against surface mining included preservation of the landscape and environment, the need to develop tourism, and decreased jobs for deep miners. But, as historian Chad Montrie observes, "Very quickly after the campaign against stripping moved to the national level, it became dominated by representatives of organizations who strove to be 'reasonable' and 'flexible,' viewing a ban only as a prod to get the House and Senate to pass strict controls.” By 1972, so-called "compromisers,” who included even some environmental groups such as the Sierra Club, killed the fight for abolition, with the end result being the passage of the Surface Mining Control and Reclamation Act five years later. ${ }^{20}$

Back-to-the-land migrants generally avoided settling in Appalachia's coal country, so it likely caught Lincoln alter-natives off guard when, in early 1974, a company named Capital Fuels, Inc. filed a permit application to open a surface mine in the county. ${ }^{21}$ Many of the inmigrants vehemently opposed surface mining and several quickly became key leaders in both local and state efforts to prevent the practice. West Virginia’s Department of Natural Resources had initially denied the permit because of the moratorium, but Capital appealed the decision, arguing that two clay mines had been allowed to operate in the county in 1970, a year before the moratorium was imposed. ${ }^{22}$ Capital's action evoked an immediate response from several people

\footnotetext{
${ }^{20}$ The Surface Mining Control and Reclamation Act (SMCRA) established a regulatory partnership between states and the federal government. Each state became responsible for overseeing its own control program, provided it abided by the act's standards. While SMCRA banned highwall mining, it allowed states to create their own laws about restoring mines to the mountain's original contour, relaxed standards for small operators, failed to include a consent clause for surface owners, and allowed mountaintop removal mining to become a normal extraction method rather than an exceptional method requiring a special permit.

Montrie, 134, 137-138, 177-178.

${ }^{21}$ John Alexander Williams, Appalachia: A History (Chapel Hill: University of North Carolina Press, 2002), 353.

22 “Strip Mining Ruling 2 Months off; Local Group Chooses Name,” Weekly News Sentinel, August 14, 1974.
} 
in the county. In July 1974, Ric MacDowell, who had come to West Virginia in 1968 as a VISTA volunteer and settled on an old farm, founded Lincoln County Citizens to Abolish Strip Mining along with six newcomers and two natives, including Darrell McGraw, who later became the state's attorney general. Although their organization started small, it quickly built support. By November, fifty people joined LCCASM in a protest at the state capitol. ${ }^{23}$

Organizing efforts began with letter writing campaigns, protest rallies, and information sessions with Congressman Hechler, an outspoken opponent of the practice. ${ }^{24}$ Capital Fuels responded to activists' letters to the editor by publishing advertisements in local and regional papers that touted coal as a solution to the nation's energy crisis and the county's economic woes. The company had a few outspoken local supporters. One man expressed his frustration with the lack of mine training available in the county. He blamed opposition to surface mines not on alter-natives but on the Board of Education and "merchants and wives of merchants who don’t have to worry about a job.” That same day, another man responded to a letter from an alternative who had written to the local paper a week earlier expressing her opposition to surface mining. The man suggested that she and the other back-to-the-land migrants feigned poverty so that they could use welfare to support themselves. "They even enroll in our institutions of higher learning while our hard working strip miners and other working people are taxed to the limit to support them," he added. "Its high time we let this lazy bunch go to work. They might find something more decent to do than all night protest marching." "Bah Hum Bug," as this person

\footnotetext{
23 “Anti-Strip Group Marches,” Weekly News Sentinel, November 27, 1974; “Anti-Strip Group Meets,” Weekly News Sentinel, November 27, 1974.

${ }^{24}$ By 1975, LCCASM helped to form the statewide group Save Our Mountains (SOM), so the name of the organization disappears after 1974. "Anti-Strip Mine Group To Hear Hechler Thurs.,” Weekly News Sentinel, October 23, 1974.
} 
signed him- or herself, was one of the first locals to publicly criticize homesteaders for their activism and ascetic lifestyles. ${ }^{25}$

In spite of some support for Capital Fuels, long-term county residents remained ambivalent about the issue, which is not surprising given the county had never been home to any surface mines. In a survey of twenty-five people conducted by the Weekly News Sentinel, one person spoke strongly in favor of surface mines, another thought it would be okay "if they'd strip it and put it back good and level and nice," and four spoke against them. The rest of the residents remained uncertain. ${ }^{26}$

Although residents debated the issue during 1974 and the early part of 1975, there is little evidence of any significant hostility being expressed toward anti-strip mine activists at the time. Protests and related activities remained relatively peaceful. Even the political climate in the state remained relatively favorable to the cause. When the time came for the West Virginia's House of Delegates to vote on whether or not to extend the moratorium, MacDowell presented state legislators with a petition bearing 1,500 signatures from Lincoln County citizens. ${ }^{27}$ State Senators Todd Willis and Robert Rogers took notice. In a statement written to Gene Gainer, Chairman of the Natural Resources Committee, Senator Rogers expressed that he was "not for the abolishment of strip mining." "However," he continued, "it appears to me that my constituents in Lincoln County are most interested to see that their county is not exposed to strip mining." 28 On January 22, 1975, the local paper reported that the moratorium would continue until March 12, 1977. ${ }^{29}$

\footnotetext{
${ }^{25}$ Leonard Silverado, “Reader’s Corner, Mr. Brewer,” Weekly News Sentinel, March 19, 1975; Bah Hum Bug, “Dear Sir and To Whom It May Concern," Weekly News Sentinel, March 19, 1975.

26 "Mixed Feelings on Strip Mining Are Evident Here," Weekly News Sentinel, August 21, 1974.

27 “Strip Mining Ban Legislation Passes Here,” Weekly News Sentinel, January 22, 1975.

28 "Senators Do Support the Moratorium,” Weekly News Sentinel, February 26, 1975.

29 “Strip Mining Ban Legislation Passes Here,” Weekly News Sentinel, January 22, 1975.
} 
The tolerance deteriorated somewhat between 1976 and 1977. News reports of ongoing threats to the moratorium intermingled with other articles and letters to the editor that addressed complaints about "people with long hair" and the high number of people on welfare; warned readers about Jeremiah Greenberg, a vocal and charismatic alter-native who became a registered marijuana lobbyist in the state; and chronicled the formation of another environmental group made up of landowners who tried to address pollution coming from an oil operation in Griffithsville. ${ }^{30}$ In 1977, just before the moratorium was set to expire, tension peaked. A hearing was held in Charleston at the beginning of March to decide whether or not to continue the moratorium for another two years. Several Lincoln County residents attended including Jack Spadaro, who testified that strip mining caused erosion, stream pollution, and severe flooding. Other residents supported his testimony, arguing that flooding from strip mines would cause financial loss, particularly from crop damage. Bill Mohler, a Charleston-based lumber company owner who held coal and timber rights in the county, countered that a proposed highway would cause more damage to the landscape than strip mining. ${ }^{31}$ That same day, the Lincoln Journal's editor, Gene Brewer, published a scathing editorial attacking “outsiders” who he felt were wrongly telling local landowners what they should and should not do with their land. "Those opposed should be willing to pay the landowner for keeping the coal in the ground," he wrote, "if they are so damn set on keeping our state so beautiful.” He continued, “I don’t feel the environmentalists should deprive or discriminate against a land owner unless he is willing to pay to keep the coal from being stripped. But all they ever offer is a lot of mouth.”32

\footnotetext{
30 "Bill to Strip Mine Lincoln Introduced,” Weekly News Sentinel, January 28, 1976; Linda Browning Martin, “Editor, Lincoln County Journal,” Lincoln Journal, March 9, 1977; Lover of Hair, “Dear Haters of Hair,” Weekly News Sentinel, February 11, 1976; Thank You, "Dear Mr. Brewer,” Lincoln Journal, March 2, 1977; E.B. Gillenwater, "In View of Guyan Oil Recovery Project Long-Time Griffithsville Resident Asks: Whatever Happened to My God Given Rights To...," Lincoln Journal, March 9, 1977.

31 “County Stripping Ban Supported at Hearing,” Lincoln Journal, March 9, 1977.

32 “Anti Strippers Willing to Pay Land Owners?” Lincoln Journal, March 9, 1977.
} 
Two people published rebuttals in the following weeks. Alvin R. Messinger accused the editor of lacking concern for people outside of Hamlin, the county seat, "because there would be little chance of strip mining" there. "But have you ever considered what it would do to the people and the environment in the remote places of Lincoln Co.," he asked. He appealed to the county's hunters and fishermen by reminding them that they had much to lose from the practice. And in response to Brewer's comment about outsiders' influence, he said, "It is great to know that someone else cares.”33 Julian Martin, a native West Virginian who had kinship ties in the local community and friendship ties to alter-natives, charged that the coal companies were the outsiders and that if they were taxed "what they ought to be taxed we would have the best schools in the country instead of the ram-shackle buildings we have now.” He also contended that the anti-strip mining movement enjoyed a significant amount of local support. ${ }^{34}$ Still, in spite of the activists' efforts, the moratorium ended in March 1977.

No sooner did the moratorium expire than two permits, one for prospecting and one for mining, were issued. Bill Mohler allowed Southern Appalachian Coal Company, a subsidiary of Appalachian Power, to apply for a permit to prospect on twenty acres of his land near Woodville. The prospecting permit was submitted to the Reclamation Department, part of West Virginia's Department of Natural Resources, in anticipation of opening a 152-acre strip mine. MacDowell and Save Our Mountains charged that the company failed to hold a meeting for public comment prior to the permit being issued, but the Department of Natural Resources claimed that comment periods did not apply to prospecting permits. Responding to the disagreement, Brewer again attacked his opponents, saying that they should either foot the bill to purchase land from the coal companies “or else shut up." Like many others who wanted strip mining in the county, he cited

\footnotetext{
${ }^{33}$ Alvin R. Messinger, “To the Editor,” Lincoln Journal, March 23, 1977.

34 Julian Martin, interview by author, Morgantown, WV, June 10, 2010; Julian Martin, “Dear Editor,” Lincoln Journal, March 23, 1977.
} 
the need for jobs and a boost to the county’s lagging economy as reasons to allow the process. He also reminded readers that the "legislature had an opportunity to continue the moratorium here and a majority chose not to do so.”35 The second permit, which was advertised in the classifieds, was issued to Spur and Associates. This company wanted to mine southeast of Hamlin near Spurlocksville. In another letter to the editor, Martin warned readers about the permit and encouraged them to protest. He also accused Brewer of burying the news of the permit in the classified section and questioned whether the man stood "to make money from strip mining." 36

For the next two years, the community was divided over the issue. On February 21, 1978, a public meeting at the Martin Elementary School discussed the two permits. In spite of the occasionally hostile banter that had been going back and forth in the newspaper during the weeks leading up to the meeting, it proceeded without incident. According to one woman who was interviewed for the article, the majority of attendees were in favor of allowing strip mining in the county. ${ }^{37}$ But on April 4, the paper again reported that a number of local citizens met to demand a public hearing to discuss the two permits. This time, the county court became involved because the proposed Spurlockville mine lay within the protected Mud River Watershed. Activists pointed out that the Woodville mine would also affect the watershed. The article suggested that there was a spirit of cooperation between native citizens, the county court, and Save Our Mountains during the companies’ permitting phase. One local elder even opined that the newcomers' activism injected a new sense of civic duty and community participation into the county:

\footnotetext{
35 “Abolitionists Should Put Up or Else Shut Up,” Lincoln Journal, December 14, 1977.

36 Julian Martin, “Reader's Corner,” Lincoln Journal, December 28, 1977.

37 “Pros and Cons of Strip Mining Are Aired At Public Hearing At Alkol,” Lincoln Journal, March 1, 1978.
} 
“It used to be that people in Lincoln County would run away from the big folks; now they’re beginning to stand up to them.”38

The county court ruled against Spur and Associates on the grounds that it would have affected the watershed. But Southern Appalachian Coal pressed on. In July of 1978, the court held a public hearing at the Duval High School Gym to discuss the permit. Community interest was piqued, for nearly five hundred people attended the meeting. Southern Appalachian Coal was allowed to give a thirty minute presentation on the proposed mine, but citizens’ groups, including Save Our Mountains and the Jesuit Appalachian Ministry, were not allowed to deliver presentations. This angered people like Father Joe Hacala, a Catholic missionary in the county who "strongly object[ed] to this procedure" and thought that "the 300-400 of us here can make our voices heard.” Still, individuals were allowed to speak, and nearly sixty signed up to do so. This time strip mine opponents outnumbered supporters ten to one. News reports covering the meeting demonstrate that there were both natives and newcomers against the mine. "If you like mud, come look at it. I am opposed to strip mining,” said one man who had worked construction on a surface mine. ${ }^{39}$

In late July 1978, Southern Appalachian Coal’s permit was denied on "aesthetic and technical” grounds. The Director of the Department of Natural Resources, David Callaghan, explained that his decision was based on community concerns that the mine "would create an imminent and inordinate peril to the welfare of the state by disrupting the way of life, the peace and tranquility in the community and in the area of proposed operation.” Although everyone expected Southern Appalachian to appeal the decision, which it did, activists had put enough pressure on the Department to prompt denial. Surface mine proponents were outraged. Ben

\footnotetext{
38 “Some Lincoln Citizens Press for Strip Mine Hearing,” Lincoln Journal, April 19, 1978.

${ }^{39}$ Peggy Lageman, “Tempers Flare During Hearing on Strip Mine,” Lincoln Journal, July 19, 1978.
} 
Greene, president of the West Virginia Surface Mining and Reclamation Association, lashed out at Lincoln County alter-natives by saying that they were "sacrificing citizens' welfare for 'an 1890s lifestyle." ${ }^{40}$ Gene Brewer again blamed alter-natives for the county's high welfare rates and asserted that people "from other counties and other states" should be left out of community meetings. "The people of this county need to make their own decisions," he asserted, "not relying on some well-meaning but often mis-guided outsider to make up our minds for us.” ${ }^{41}$ And local strip miner Ray Midkiff exclaimed, “Hooray for the 'outsiders'! Again they have come into Lincoln County telling us what is good or bad for us ... How many real Lincoln countians (not transplants) were at the hearing?” Midkiff too targeted the county's alter-natives as welfare recipients: "I wonder how many of those present bore a striking resemblance to those one sees standing in front of the welfare office waiting in line to get their checks \& stamps, you know the men in pony tails who can't, or is it won't, find work. But that is different—we taxpayers make it all possible.” Midkiff expressed his frustration with homesteaders again in September: “We typical Appalachians do not like to be cheated of our dues by 'outsiders' or 'ferreners.”' To prevent in-migrants from having any future influence on the permitting process, he suggested meetings be limited to "land owners, residents, and registered voters." 42

In September 1978, John Salstrom, who had not been heavily involved with the issue up to this point, submitted a rebuttal to Brewer and Midkiff. He said that even though he was an “outsider," he worked hard and kept himself and his family off of welfare. And no matter how desperate he became, he claimed he would "never...take a job that meant destroying my neighbors' land and water.” Just because people were new to the area did not mean that they did

\footnotetext{
${ }^{40}$ Paul Akers, “Stripping Appeal Planned; Environmentalists Rejoice,” Lincoln Journal, August 2, 1978.

${ }^{41}$ Carl Brewer, "We Favor Strip Mining; We Print Both Sides,” Lincoln Journal, August 23, 1978.

${ }^{42}$ Roy L. Midkiff, “Letters to the Editor,” Lincoln Journal, August 9, 1978; Roy L. Midkiff, “Dear Mr. Brewer,” Lincoln Journal, September 6, 1978.
} 
not "have a right to speak their mind.” Echoing the opinion of Julian Martin and others who had spoken out against surface mining, he asserted, “outsiders are the fancy dressers running the coal companies from New York and Pennsylvania.”43 Tim Wildermuth likewise responded to Brewer's accusations about alter-natives on welfare. He questioned whether the recipients would actually be the ones benefiting from surface mines and then pointed out that areas that had previously been stripped often had higher welfare rates than they did before the practice began. ${ }^{44}$ In November of 1978, the local paper reported that a date was set for the Board of Reclamation's hearing on Southern Appalachian Coal. By this time, the paper was calling the contest "the great Lincoln County strip-mine fight." 45 In spite of the opposition, county administrators anticipated a coal boom that they believed would attract as many new miners as the county’s rock-bottom land prices had attracted alter-natives over the last ten years. ${ }^{46}$ But their hopes did not come to fruition, at least for the better part of a decade. Because of an injunction filed by SOM and several other delays, there was no decision until the end of 1979 when the Board denied Southern Appalachian Coal's permit, leading to the sale of the company. $^{47}$

Native/newcomer distinctions did not completely disappear from the newspaper; community disputes continued over tax reform and education, so nerves remained raw and accusations of non-natives’ influence continued to surface through 1980. But tension eventually

\footnotetext{
${ }^{43}$ Salstrom, interview; John Salstrom, “Editor,” Lincoln Journal, September 6, 1978.

${ }^{44}$ Tim Wildermuth, "Dear Mr. Brewer," Lincoln Journal, September 6, 1978.

45 “Strip Mining Fight’s Next Round is Friday,” Lincoln Journal, November 29, 1978.

46 "Jump Seen in Population Here," Lincoln Journal, November 21, 1978.

${ }^{47}$ Bob Schwartz, "Crossroads with Coal,” Weekly News Sentinel, June 17, 1987. It should be noted that the inflamed rhetoric from the Southern Appalachian Coal fight came in the context of worsened economic conditions for the county. By the end of the 1970s and into the early 1980s, the national economy suffered inflation spurred by the OPEC oil crisis. This, combined with the closing of a garment factory that had once employed 358 people, left Lincoln County as the poorest in its southwestern subregion. Nearly $13 \%$ of Lincoln Countians relied on food stamps in 1980; one in ten received welfare checks. The county's unemployment rate went from 11.9 in 1978 to 30.9 in 1983. Lincoln's tax revenues were by far the lowest of all of its neighboring counties. In fact, Lincoln's economic situation was so bad, there was talk among some officials about dissolving the county altogether. See Eller, 193-197; Paul Akers, “Divvy Up County Among Prosperous Neighbors?” Lincoln Journal, January 30, 1980.
} 
calmed, as did the threat of strip mining for the next seven years. After Southern Appalachian Coal's defeat, no other surface mining companies showed interest until P\&C Bituminous Coal applied for a permit to open a mine on the Lincoln and Wayne County line during the summer of 1987. Remarkably, West Virginia's Department of Energy, which had taken over the permitting process from the Department of Natural Resources in 1985, received only six letters of protest. A public forum held on June 4 attracted forty-five people, and the attendees in favor of and opposed to the mine were evenly divided. One protest was held in July, but this too seemed subdued compared to earlier campaigns. That same week, the deputy director of the Department of Energy approved the permit, arguing that the activists had not been "specific enough" in their reasoning against the mine "to justify its denial." 48

It is difficult to determine exactly why $\mathrm{P} \& \mathrm{C}$ had such an easy time receiving a permit in Lincoln County. Because there had been no threat of mining since Southern Appalachian Coal lost its battle in 1979, it is possible that anti-strip mining activists failed to mobilize quickly enough. The public hearing and protest took place during the summer, a season that John Salstrom later indicated was troublesome for Home Place, as many people left town for vacation. But state and national political shifts may also shed light on this question. As alter-native David Buer noted, when Governor Arch Moore moved the permitting process to the Department of Energy, he also appointed former strip mine operator Kenneth Faerber as Energy Commissioner. Faerber consistently acted in the interest of coal companies, including when he revoked state

\footnotetext{
${ }^{48}$ Roughly twelve adults carrying signs and passing out literature met at the county courthouse for about an hour. They then went door to door to talk to residents about the adverse effects of strip mining. "Strip Mine Decision Rests with Commissioner," Weekly News Sentinel, June 10, 1987; "Strip Mine Protest at Hamlin Courthouse," Weekly News Sentinel, July 1, 1987; "Surface Mine Application Approved,” Weekly News Sentinel, July 8, 1987.
} 
mining inspectors’ power to obtain warrants against companies who violated environmental regulations. $^{49}$

Enforcement of regulations was much looser during the Reagan administration than it had been under Carter, and Governor Moore and Commissioner Faerber replicated this permissive atmosphere. Environmental groups accused the Reagan administration of running an “incompetent, unstable, chaotic and ineffective” Office of Surface Mining, which, in turn, resulted in a lax regulatory atmosphere in West Virginia. As evidence of this, James S. Lyon of the Environmental Policy Institute noted publicly that when the federal government had given West Virginia authority to regulate its own mines in 1982, the state had sixty-nine reclamation inspectors. By 1988, it had only forty-six. But environmentalists were not the only ones concerned; even Representative Nick Joe Rahall worried, correctly as it turned out, that because neighboring Kentucky and Virginia had made efforts during the 1980s to tighten oversight of their own state regulations, wildcat operations would flock to the Mountain State. ${ }^{50}$

Another shift had occurred in the mining industry that affected employment between the 1970s and 1990s, and this likely contributed to native/newcomer tensions that surfaced toward the end of the decade. Regional historian Ronald Eller notes, "globalization, technology, and the

\footnotetext{
${ }^{49}$ By 1988, the federal Office of Surface Mining had twice ordered Faerber to enforce laws stipulating that mine owners had to reclaim sites after prospecting. Because of Faerber's continued unwillingness to regulate surface mining, a hearing was held on April 25 of that same year to determine whether there had been an increase in illegal, or "wildcat," mining operations like Black Gold and Mountain Black Diamond. David Buer, "Apology Not Adequate,” Weekly News Sentinel, August 8, 1987; “Only Faerber Can Issue Environmental Warrants,” Williamson Daily News, November 17, 1986. See also Paul Nyden, "OSM issues another enforcement order,” Sunday Charleston Gazette-Mail, February 7, 1988; West Virginia Coal Regulatory Program, Oversight Hearing before the Subcommittee on Mining and Natural Resources of the Committee on Interior and Insular Affairs, House of Representatives, $100^{\text {th }}$ Cong., $2^{\text {nd }}$ Session, Serial No. 100-39, 1988.

${ }^{50}$ Paul Nyden, “OSM failing, panel told,” Sunday Gazette-Mail, February 28, 1988; see also Ronald D. Eller, Uneven Ground: Appalachia Since 1945 (Lexington: University Press of Kentucky, 2008), 252. Third District Congressman Bob Wise was also concerned about regulation. He was the one who eventually called for the Office of Surface Mining to hold a hearing regarding Black Gold and the state Department of Energy's willingness to issue a permit to the operation. The oversight hearing was held in April 1988 to determine whether Faerber and the DOE had acted against the law in allowing some surface mining permits to be issued. See Dan Elman-Roche, "Wise not intimidated," Weekly News Sentinel, April 6, 1988.
} 
extension of the federal Clean Air Act in 1970,” along with a decreasing supply of easily accessible underground coal seams, led to increased surface mining and, in turn, drastic declines in the number of Appalachian miners. ${ }^{51}$ In 1978, West Virginia had 63,000 miners. By 2003, there were fewer than $15,000 .^{52}$ Faerber reported to a panel in the fall of 1986 that the mining employment figures were the lowest they had been since $1900 .^{53}$ These changes shook Lincoln County. One deep miner reported that he typically drove 100 miles a day to work in neighboring counties’ mines. ${ }^{54}$ While between 1970 and 1980 Lincoln County had seen an impressive 86\% increase in resource extraction jobs (including coal, oil, and gas), those jobs only increased by 16\% between 1981 and 1991. Thirteen extraction firms existed in the county in 1977; only eight remained ten years later. ${ }^{55}$ Adding further insult to injury, President Reagan's pro-business and anti-union agenda, coupled with shrinking jobs in the coalfields, delivered a powerful blow to the United Mine Workers of America, ${ }^{56}$ forcing miners to accept non-union jobs. Miners’ fierce support of Big Coal reflected their anxiety over potential unemployment.

P\&C’s permit approval had two effects in Lincoln County: it mobilized the anti-strip mining activists and, conversely, piqued other mining companies’ interest in county coal deposits. The activists voiced their concern that the P\&C permit would make Lincoln County appear to be more inviting to other coal companies. Although State Senator Lloyd Jackson dismissed those fears on the grounds that there were not "that many mineable resources in the county” except along the borders, it turned out that the activists' fears were justified. Riding on

\footnotetext{
${ }^{51}$ Eller, 225.

52 Tom Vanden Brook, "Recruits Hungry for Good Jobs Head Off to Coal Mines,” USA Today, February 14, 2006, under "Recruits Hungry for Good Jobs Head Off to Coal Mines,"

http://www.usatoday.com/money/economy/employment/2006-02-14-miners-cover-usat_x.htm (accessed April 12, 2009).

${ }^{53}$ Associated Press, "More mining jobs likely to disappear," Williamson Daily News, October 8, 1986.

${ }^{54}$ Carl Neace, "Would Like County Work,” Weekly News Sentinel, January 20, 1988.

${ }^{55}$ Center for Economic Research, County Data Profile: Lewis - Marion (Morgantown: West Virginia University Press, 1993); Mining jobs in Lincoln County include coal, oil, and gas.

${ }^{56}$ Eller, 226.
} 
P\&C's heels was another company interested in opening a strip mine. But this time, the proposed mine was near Hamlin, where the population was heavier, rather than on the county border.

Black Gold and Mountain Black Diamond began prospecting in July 1987 during the same time as the P\&C protest. Delbert Burchett, the man who would confront federal mining engineer Spadaro at the community meeting the following January, went door to door along Six Mile Creek asking if landowners would be willing to sell their land to Black Gold. His activity alarmed the thirty-two residents living within a half mile of the proposed mine, and on July 19, John Salstrom and three other residents met with two attorneys to discuss ways to prevent the mine from opening. ${ }^{57}$ Five months later, the companies published their permit notice in the newspaper. That same day, Salstrom's wife, Jan, wrote to people in the community to notify them of the formation of a new organization, Home Place, Inc., which they hoped could stop Black Gold. ${ }^{58}$ The Black Gold/Mountain Black Diamond battle had begun.

Indianapolis native Sandra Perry incorporated Black Gold in 1987 in the state of West Virginia and formed a joint venture along with Montana native Michael Letson of Mountain Black Diamond. In her first interview with Weekly News Sentinel reporter Paul Carson, Perry discussed her plan to settle locally and boasted that the mines would provide jobs and revenue for the county. But she admitted her surprise at the amount of local opposition to surface mining. "I never thought it would be such a job to get this going here," she said. She claimed that while some people had spoken to her in person about their concerns for the environment, she had also received threatening phone calls. The nature and extent of those phone calls cannot be

\footnotetext{
${ }^{57}$ John Salstrom personal papers.

58 “Location Map,” Weekly News Sentinel, December 12, 1987; John Salstrom personal papers.
} 
determined, but if they did occur, they served as a harbinger of the tension that was to come in the following months. ${ }^{59}$

In the two months following Perry’s interview, the local newspaper was full of letters to the editor expressing both support for and opposition to the operation. In the waning months of 1987, the discourse in the newspapers was relatively civil. The majority of mine proponents cited joblessness, miners' difficulty finding local work, high welfare rates, and a low county tax base as their reasons for supporting the practice. ${ }^{60}$ Lincoln County’s unemployment rate declined from its 1983 peak, but it still hovered around 15\% in 1988. The national unemployment rate at the time was 5.5\%. ${ }^{61}$ A letter by Gary Elkins is representative of this group: “According to a TV poll,” he wrote, “70 percent of Lincoln County is on welfare. Don’t you think it is about time they had a chance to get away from this . . . Believe me, Lincoln County could use the jobs and tax money this strip mine could create.” Trying to appeal to both hunters and environmentalists, he said that he had seen “deer, bears, rabbits, and ringneck pheasants at the construction site. They also have ponds, stocked with fish, fruit trees, and a shooting range.” ${ }^{62}$ A few letters expressed frustration with perceived “opposition to progress” in the county, but native/newcomer

\footnotetext{
${ }^{59}$ Paul Carson, “New Coal Operation Expected in Branchland,” Weekly News Sentinel, November 25, 1987.

${ }^{60}$ Appalachia's economy continued to suffer for most of the 1980s, but 1985-1989 was particularly painful. Historian Shirley Stewart Burns calls it the worst economic period in West Virginia "since the Great Depression." Reagan's anti-union stance and his budget cuts to the ARC and other social welfare programs, the movement of manufacturing overseas - the garment factory in Lincoln County suffered that fate-and another burst of mining mechanization left many coalfield residents with no job and a weakened safety net. "Labor Force Statistics from the Current Population Survey," Bureau of Labor Statistics, June 20, 2008, under "Where Can I Find the Unemployment Rate for Previous Years?”; Eller, 210; Burns, 66.

${ }^{61}$ A letter to the editor from Ralph and Jean Woodall conveys the desperation that some residents felt. When they wrote to the local paper to show support for Black Gold, several of their children had already left West Virginia for lack of work, while "two sons [were] looking for work here." Exasperated, they added, "They can't even get the promise of a job. You can’t buy a job in Lincoln County.” Outspoken Black Gold supporter Albert Thompson painted an equally grim picture. "There are some really nice folks here in Lincoln County," he wrote. "A county that is in gross lacking of industry. A county that has a very high unemployment rate. A county that has third generation welfare recipients. A county wherein the state is the largest employer. A county that has FAILED to progress." "Labor Force Statistics from the Current Population Survey,” Bureau of Labor Statistics, June 20, 2008, under "Where Can I Find the Unemployment Rate for Previous Years?” http://www.bls.gov/cps/prev_yrs.htm (accessed April 30, 2009); Ralph and Jean Woodall, "Thanks Black Gold for Coming,” Weekly News Sentinel, February 17, 1988; Albert L. Thompson, "Heads in the Sand,” Weekly News Sentinel, January 27, 1988.

${ }^{62}$ Gary Elkins, “Miner Supports Black Gold,” Weekly News Sentinel, February 3, 1988.
} 
distinctions were absent at first. Albert Thompson, like Gary Elkins, framed his support for the mine in terms of desperately needed jobs and economic support for the county, but he also complained about the "county citizens [who] need to pull their heads out of the sand.” Jeffrey Wade likewise made a vague reference to different groups in the community: "Some of us want better schools for our children, improved public works, flourishing businesses, nice homes, recreational facilities and the pleasure of not having to travel one hundred miles to and from work each day.”63

The opposition, of course, argued that the devastation strip mining caused was not worth the few jobs that could be created or few thousand dollars the county would receive in severance taxes from the companies. “Advocates of strip mining emphasize that we need more jobs,” noted Don Churchill. "We do. We need more jobs desperately. To deny that would be stupid and heartless. But when it comes to strip mining, the promise of jobs to a job-starved community may be a dangerous lure... Let us remember that the purpose of stripping land is not to make jobs but to make money, most of it for people far from here.” 64

The tone of the letters to the editor changed after Jeremiah Greenberg, the former marijuana lobbyist who still held land in the county but no longer resided there, submitted a letter of support for the anti-strip mine activists. Although Greenberg wrote with good intentions, his letter may have had the unanticipated effect of reminding some Lincoln Countians of stark differences in values that, at least in the 1970s, had existed between themselves and the countercultural in-migrants. ${ }^{65}$ A week later, and one week before the public meeting at the Hamlin Community Center, the paper ran an article on Greenberg, the man they claimed "was

\footnotetext{
63 Albert L. Thompson, “Heads in the Sand,” Weekly News Sentinel, January 27, 1988; Jeffrey Wade, “Opportunity is Knocking,” Weekly News Sentinel, January 27, 1988.

64 Don Churchill, “What is Proper Land Usage?” Weekly News Sentinel, February 24, 1988.

65 Jeremiah Greenberg, “Keep Mining Out of County,” Weekly News Sentinel, January 13, 1988.
} 
once the leader of the so-called counterculture here in Lincoln County; a man whose very name was synonymous with pot smoking; a man who many parents felt was a threat to their childrens’ morals.” Greenberg had since quit smoking marijuana after finding his faith in Messianic Judaism. But the article also recalled the "ire” that Greenberg once "raised . . . among parents" and the fear that he and others like him were responsible for "nurturing a 'drug culture.",66 One mine supporter immediately latched on to the idea that homesteaders had fostered a "drug culture” in the community. Earnest P. Salmons reminded readers of Greenberg's marijuana legalization campaigns and a Fourth of July anti-Vietnam War demonstration where a group of newcomers allegedly burned a flag. He then questioned whether Greenberg and others “were the kind of people we want blocking the progress of our county.”67

Tension in the community escalated in the weeks leading up to the January 29 meeting at the Hamlin Community Center, and by the time of the meeting, it had reached a breaking point. Roughly 150 people attended, and the majority did so in support of the mine. Perry, Burchett, and Midkiff had actively recruited surface miners from area mines, especially the Hobet mine in neighboring Boone County, to attend the meeting. ${ }^{68}$ In a testimony delivered to the West Virginia Coal Regulatory Program’s oversight hearing later that year, Lincoln native Sandra Miller recalled, “The coal company, from what I could see, had planned beforehand to totally dominate the whole meeting.” When Salstrom and other mining opponents got up to speak, Perry and some of the miners heckled them. “The moderator, Mr. John Salstrom,” stated Miller, “was made fun of by Mrs. Perry and her colleagues. I was sitting directly behind Mrs. Perry and was a

\footnotetext{
${ }^{66}$ Several alter-natives, including Kate Lambdin and David Buer, refuted the notion that Greenberg was any kind of "leader" among them. "I do not smoke marijuana and I love my country," wrote Buer. Lambdin attacked the notion that Greenberg was some sort of countercultural leader as "ludicrous.” See Dan Elman-Roche, "Jeremiah’s life different now," Weekly News Sentinel, January 20, 1988; Kate Lambdin, "Jeremiah Not the Leader," Weekly News Sentinel, February 3, 1988; David Buer, "Resident Responds,” Weekly News Sentinel, February 3, 1988.

67 "Disagrees with Jeremiah,” Weekly News Sentinel, January 20, 1988.

${ }^{68}$ Salstrom, interview; Spadaro, interview; John Salstrom personal papers.
} 
witness to this myself." ${ }^{69}$ Alter-native Jim Chojnacki was harassed as well. During his speech he predicted that the county would see a coal boom, an assertion that elicited cheers from the miners. But he quickly added his concern that a bust would almost certainly follow. ${ }^{70}$ Alarmed by the hostile atmosphere, Julian Martin left before many people had spoken. ${ }^{71}$ Salstrom remained but adjourned the meeting early because of the conflict between Spadaro, Burchett, and Midkiff. The meeting, he recalled, was "real intense. Very, very intense.,"72

Threats of violence spilled over into the following days. In the early hours of the morning following the meeting, John Salstrom received word from a friend—a retired deep miner-that a group of angry miners had assembled in nearby Branchland with the intent to burn down his home. The threat never came to fruition, but it alarmed Salstrom enough to send his ten-year-old daughter into hiding with her infant brother. ${ }^{73}$ On a couple of occasions Salstrom sent his "family out of state to keep them out of any dangerous situations." ${ }^{74}$ He later testified that Jennings Midkiff had threatened one member of Home Place "with the 'Klan,' to get him out of the county." 75

Inflammatory rhetoric and direct attacks on alter-natives continued to appear in the local paper, but only briefly. On February 10, Arthur Burton of Griffithsville asked readers, "Do people want to go back to the horse and buggy days? I sure don't!” he responded. “I'm for progress!” The following week, Ralph and Jean Woodall asserted, “This is 1988, not 1888.” They called for a survey to be conducted of how many people were "born in West Virginia—not

\footnotetext{
${ }^{69}$ In spite of the heckling, John Salstrom maintained in a handwritten note that a majority of the miners "were wellintentioned and not disruptive.” West Virginia Coal Regulatory Program, Oversight Hearing, 57; John Salstrom personal papers.

${ }_{70}^{70}$ Dan Elman-Roche, “Tempers Flare Over Strip-mine Issue,” Weekly News Sentinel, February 3, 1988.

${ }^{71}$ Martin, interview.

${ }^{72}$ Salstrom, interview.

${ }^{73}$ Salstrom, interview.

${ }^{74}$ John Salstrom personal papers.

${ }^{75}$ West Virginia Coal Regulatory Program, Oversight Hearing, 371.
} 
to mention Lincoln County.” In an interview with Huntington, West Virginia’s Herald-

Dispatch, Jennings Midkiff asserted that "the whole problem could be traced to 'marijuana' and 'hippies’” in the county. "We really don’t know what they're doing here,” he continued. "They're outsiders. They don’t work and they don’t give a lick about this county.,"76

Natives and newcomers alike spoke out against the native/newcomer distinctions. On March 3, John Salstrom wrote, "One thing that it implies is that anyone not indigenous to Lincoln County has no right to an opinion on the subject. My God, people we can’t start our lives over and be born in Lincoln County." ${ }^{77}$ Two weeks later, he attacked Midkiff's marijuana comment as "incendiary" and charged that it was "intended to discredit all opposition to [the Black Gold] proposal." ${ }^{78}$ Maggie Hennessey, a Buckeye Hollow homesteader, asked, "When do I graduate from an 'outsider' to an 'insider?',79 Sandy Adams, an Ohio County, West Virginia, native, exclaimed, "I’ve had it with being called an 'outsider.”' He pointed out that his father had served as a state legislator, and that he himself had lived in Lincoln County for eighteen years. ${ }^{80}$ Eighty-year-old Leslie Baker of Branchland echoed Adams' frustrations: “Some of the letters I've seen claim that the people against strip mining or against Black Gold are all 'outsiders' or just troublemakers. Well,” she continued, “I don't think I’m an outsider after being here 80 years and my parents and grandparents before that.” She feared that strip mining would destroy the land and expressed her hope that "young people would go back to farming." ${ }^{81}$ And Thursy Baker, a native involved with Home Place, questioned the use of "insider" and "outsider" labels: "There has been a lot said and written lately about who has the most rights in Lincoln County. Is

\footnotetext{
${ }^{76}$ Arthur R. Burton, “Coal means progress,” Weekly News Sentinel, February 10, 1988; Ralph and Jean Woodall, “Thanks Black Gold for coming,” Weekly News Sentinel, February 17, 1988; Sean Nolan, "Community of Conflict: Lincoln strip mine job generates hard feelings,” Herald-Dispatch, February 16, 1988.

${ }^{77}$ John Salstrom, "County man outlines facts,” Weekly News Sentinel, March 16, 1988.

${ }^{78}$ John Salstrom, "County man outlines facts."

${ }^{79}$ Maggie Hennessey, “Don’t Sell Out,” Weekly News Sentinel, February 3, 1988.

${ }^{80}$ Sandy Adams, "Had it with being an 'outsider,” Weekly News Sentinel, February 10, 1988.

${ }^{81}$ Leslie Baker, “Opposes stripping,” Weekly News Sentinel, February 24, 1988.
} 
it the 'insider' or the 'outsider'?” She concluded, “Anybody who has been here long enough to vote has as much rights as anyone, whether it be me or you." ${ }^{22}$

The Lincoln County conflict drew statewide attention. About a month after the meeting, Huntington's Herald-Dispatch devoted an entire Sunday section to the fracas. The headline, which read, "Clash of Coal and Culture," suggested that a deep ideological division was occurring in Lincoln County between alter-natives and people who saw the mine as a good economic opportunity. On one side, the report relayed, were homesteaders like Chojnacki. Even though by 1988 alter-natives had largely re-integrated into the mainstream economy by taking conventional jobs, Chojnacki and a few other hold-outs excepted, his belief "in a close and respectful relation with the land" was an accurate representation of that population's continuing desire to see the county's natural resources preserved. ${ }^{83}$ Leading the other side was Sandra Perry of Black Gold, who had asserted to the reporter that she feared for her life in Lincoln County. She felt that communism and drugs were entrenched in the community. "I believe West Virginia may be seen as the last foothold for communism in the country,” she told the Herald-Dispatch. Referring to a turret on John Salstrom's new home, she expressed her belief that “sophisticated radio equipment and towers” were being used to send signals from Lincoln County to Moscow. She observed how strange it was that back-to-the-land farmers could live on such meager salaries, suggesting that Russia supported their agrarian lifestyles. To provide evidence for her accusations, she produced a communist book from the library that had been checked out five times since 1974. Stuck somewhere in the middle of the debate were a group of landowners

\footnotetext{
${ }^{82}$ Thursy Baker, “Neighbors must stand together,” Weekly News Sentinel, February 17, 1988.

${ }^{83}$ The alter-natives' integration into the economy may be the reason why there were fewer comments being made in the local paper about that population relying on welfare than there were during the anti-strip mine battles of the 1970s.
} 
concerned about how the mine might affect water quality, the stability of their homes, and property values. ${ }^{84}$

Perry's accusations of communism and drug use in the county did not have the effect that she had hoped. A number of people who might have continued to support Black Gold questioned her motives in airing local rumors to the press. The Weekly News Sentinel's Paul Carson, who favored surface mining in the county, conjectured that "Black Gold must be getting desperate" because Perry had "effectively lowered the debate over strip mining in Lincoln County to a level of name-calling and finger-pointing as she characterized her opposition as communists operating their own little marijuana cartel.”85 A surface miner who lived along Six-Mile Creek likewise criticized the company: “It's not a matter of strip mining," said Pete Miller, “This is a matter of the company and their attitude.”86 At the oversight hearing on April 25, Congressman Nick Jay Rahall scolded Perry for going public with accusations that she, under pressure, acknowledged as “only hearsay.” To that, Rahall replied, "Well, would you agree that hearsay has no place to be in the public print, then?”87

Black Gold received a second and more serious blow from Jack Spadaro and the Charleston Gazette-Mail. Shortly after the Herald-Dispatch article appeared, the Gazette-Mail issued an exposé on Delbert Burchett. Prompted by Jack Spadaro’s own personal investigation into the man's mining activities in Kentucky, ${ }^{88}$ the article revealed that Burchett had declared bankruptcy in December of 1987, so he could not be listed on the mine permit application that Sandra Perry filed with the Department of Energy. He owed the IRS \$1.5 million in back taxes

\footnotetext{
${ }^{84}$ Richard Santus, “Developer: Dispute Muddled by Communists, Drug Users,” The Herald-Dispatch, February 29, 1988, D1.

${ }^{85}$ Paul Carson, “Black Gold blowing smoke,” Weekly News Sentinel, March 2, 1988.

${ }^{86}$ Paul Carson, "Proposed mine too close for comfort,” Weekly News Sentinel, March 9, 1988.

${ }^{87}$ West Virginia Coal Regulatory Program, Oversight Hearing, 171.

${ }^{88}$ Spadaro, interview.
} 
and half a million dollars to the federal Office of Surface Mining for failing to reclaim mines in Kentucky. In addition, he was engaged in a number of expensive lawsuits with other coal companies. His behavior toward several local landowners, as well as toward Spadaro at the January 1988 meeting, further damaged his community rapport. Landowner Roy Kitchen had taken out a misdemeanor assault warrant against Burchett for "making threatening remarks" when they engaged in a boundary dispute. ${ }^{89}$ Black Gold countered with a trespassing warrant against Kitchen. ${ }^{90}$ The state Department of Energy also cited the companies for prospecting without a permit, shoveling overburden into a stream, and failing to reclaim the land that they had disturbed. In light of those developments, the Weekly News Sentinel released a statement saying, "We are for strip mining ... And we are looking for assurances so we can endorse the Black Gold project. But so far we have doubts.”11

The realization that Black Gold might be a scam operation cooled the debate somewhat in the community. The county commissioners, a few surface miners, and Jennings Midkiff continued to support the joint venture—in fact, in May of 1988 he sponsored a meeting to discuss ways to eliminate the "undesirable elements" from the county so that mining could proceed. But many people, including other surface miners and state legislators, questioned the operation's legitimacy. ${ }^{92}$ Spadaro recalled that one surface miner who attended the January meeting to support the mine later confessed to him that he changed his mind after watching Spadaro challenge Burchett: “'Jack,' he said, 'You did one of the bravest things I have ever seen anybody do, and I really respect you for it.' And he said, 'I was back there with those guys, I was

\footnotetext{
${ }^{89}$ Paul Nyden, “Bankrupt operator behind Black Gold can’t get permit,” Sunday Gazette-Mail, February 7, 1988.

${ }^{90}$ Black Gold/Mountain Black Diamond sparked another controversy when it engaged in a land dispute with SixMile resident Albert Miller. Paul Carson, "Landowner, mine official trade charges," Weekly News Sentinel, February 10, 1988; Paul Carson, "Proposed mine too close for comfort,” Weekly News Sentinel, March 9, 1988.

91 "Stripping supported, Black Gold questioned,” Weekly News Sentinel, February 17, 1988.

92 "Stripping supported, Black Gold questioned,” Weekly News Sentinel, February 17, 1988; "County commissioners still support Black Gold,” Weekly News Sentinel, February 17, 1988; “More hate; that's what we need,” Weekly News Sentinel, May 4, 1988.
} 
in the crowd too, and you changed my mind."”93 Other miners changed their minds. They feared that the land would not be properly reclaimed and that the operation would be non-union. Nearly thirty of the forty people who spoke at the March 17th hearing opposed Black Gold. ${ }^{94}$

Home Place, Save Our Mountains, and a handful of local residents commenced a legal attack on Black Gold by filing suit against the state Departments of Energy and Natural Resources with the Kanawha County Circuit Court. This was done in an attempt to prohibit the former from granting a new permit to the mining companies on the grounds that the revisions were so extensive, that they warranted a completely new application. Filing a new application would require the company to hold the standard fifty-one day comment period rather than the abridged ten-day period. The court agreed with Home Place and forced Black Gold to complete a new application. ${ }^{95}$ Reflecting a dramatic shift in opinion, a second public hearing was held on June 28,1988 , and only four out of the twenty-one people who spoke did so in favor of the mine. Perry attended but did not speak. ${ }^{96}$ Midkiff spoke and reasserted his claim that the opposition was behind the county's drug problem. Alter-natives who had already spoken at the meeting and promoted farming and selective logging as alternatives, "never mentioned the right plant on Six Mile" creek, Midkiff claimed. He charged that the "good springs" people were so interested in protecting were being used to irrigate marijuana. ${ }^{97}$

From the available evidence, it appears that Midkiff stood alone in his accusations of marijuana production during the hearing. Although one of the pro-mine transcripts is missing, the other two mine supporters did not make any references to "outsiders" or drugs. And while

\footnotetext{
${ }^{93}$ Spadaro, interview.

${ }^{94}$ David Buer, "Thanks to real newspaper,” Weekly News Sentinel, March 30, 1988.

${ }^{95}$ Dan Elman-Roche, "Permit changes result in suit,” Weekly News Sentinel, March 23, 1988; Dan Elman-Roche, "Black Gold forced to start over,” Weekly News Sentinel, April 20, 1988.

${ }^{96}$ Paul Salstrom, "Cash is a Four-Letter Word," Appalachian Journal (Spring 1989): 242; Paul Carson, "I would be worried,” Weekly News Sentinel, July 6, 1988.

${ }^{97}$ J.O. Midkiff, West Virginia Strip Mining, Public Hearing held by the West Virginia Department of Energy, June 28, 1988, Special Collections Department, Marshall University.
} 
most of the anti-strip mining activists likewise refrained from engaging in native/newcomer distinctions, Julian Martin used the podium to express his outrage at Midkiff's accusations. "It seems real important in Lincoln County to establish where you're from and who you are because a lot of people laugh at you if they think you're from New York or something." "I've been a citizen of this state for fifty-two years...I've got the accent, you know, I can speak the language, okay? I'm not a foreigner." He explained to the crowd that his father had been a coal miner, and addressing Midkiff and Perry's accusations directly, he said “he wasn’t a communist, he wasn't an outsider, and he didn't deal in drugs, though he did drink a lot of coffee.” He again pointed to the coal executives as the true outsiders. ${ }^{98}$

In spite of shifting public opinion, the Department of Energy approved the new permit. Home Place appealed, and for the next two years, the environmental organizations, with a supporting cast of lawyers and geologists—several of whom were also in-migrants—kept the companies tied up in permit hearings and court cases. During this time, Sandra Perry moved back to Indianapolis, Michael Letson sold his shares of Mountain Black Diamond so that he could run for office in Montana, and Delbert Burchett left the United States in order to explore mining interests in Venezuela. Two years after Black Gold and Mountain Black Diamond had begun prospecting, the battle was over. Home Place had won. ${ }^{99}$

The lax regulatory environment of the late 1980s left citizens' groups like Home Place having to spend an enormous amount of effort to ensure that companies like Black Gold operated within the law. In order to be effective, members of Home Place had to assume the role of mining "experts.” They performed extensive technical reviews of Black Gold's applications that Salstrom boasted were "commended as admirable and worthy" by the State and by the coal

\footnotetext{
${ }^{98}$ Julian Martin, West Virginia Strip Mining, Public Hearing held by the West Virginia Department of Energy, June 28, 1988, Special Collections Department, Marshall University.

99 “Channel One Debated,” Lincoln Journal, February 7, 1990.
} 
companies' attorneys. In his prepared statement for the oversight hearing, Salstrom expressed his frustration with the amount of time and effort he had to put into those reviews and court cases. He asked: "Why do private citizens have to knock themselves out conducting an independent technical review and then have to file lawsuits to make the Department of Energy respect not only the rights and privileges of West Virginia citizens, but West Virginia law?" ${ }^{100}$ Home Place's diligence and constant pressure on the Department of Energy ultimately won the battle, but as with Save Our Mountains a decade earlier, alter-natives' assumption of the role of "expert" on mining and economic development issues left that population having to confront the local power structure, which exacerbated native/newcomer tensions. ${ }^{101}$ They escalated in Lincoln County as the commodity interests - the elite protectors of the status quo who stood to profit from mining—felt threatened. They peaked when value differences, like Greenberg's former support for marijuana legalization, were thrust back into the light.

In July of 1990, another company, Heartland Resources, Inc., posted its permit notice in the local paper. Home Place fought the permit, but the mine eventually opened on the Logan and Lincoln County border. Native/newcomer distinctions continued during the Heartland debate, although not nearly to the extent that they had previously. Perhaps the residents were tired of fighting. Perhaps native West Virginian Thursy Baker's assumption of the role of president of Home Place made the outsider label moot. Or perhaps Home Place’s alliance with the UMWA

\footnotetext{
${ }^{100}$ West Virginia Coal Regulatory Program, Oversight Hearing, 306.

${ }^{101}$ Several sociologists have found that for newcomers to be accepted as an "insiders" in their adopted communities, they must understand how to act during their interactions with other community members. This includes properly navigating local power structures. Those who try to act as "experts" or assert authority on issues related to the community may be dismissed as outsiders and excluded from the decision-making process altogether. "Incomers," says Scott K. Phillips, "are expected to take their behavioural cues from the locals, and ... they should not presume to alter local ways.” In-migrants are welcome to participate in community activities—and their engagement can afford them insider status - provided they do not act against accepted forms of behavior or attempt to change local behavioral patterns. See Lisa Moran, "Negotiating Boundaries or Drawing the Line? Transcending 'Insider/Outsider' Distinctions in Connemara,” Irish Journal of Sociology 16.2, 2007, 145-147; Scott K. Phillips, "Natives and Incomers: the symbolism of belonging in Muker parish, North Yorkshire," in Symbolising Boundaries: Identity and diversity in British cultures, edited by Anthony P. Cohen (Manchester, UK: Manchester University Press, 1986), 151.
} 
forced residents to change the nature of their arguments about strip mining and economic development. Heartland was a subsidiary of Pittston Coal Group, a company that, in 1989, abandoned a long-standing contract that provided pensions for miners through the Bituminous Coal Operators' Association. ${ }^{102}$ This action resulted in a massive strike by the UMWA, which had only been settled six months prior to the permit notice. UMWA representative Howard Green was concerned that the 100 jobs the mine was to create would wind up going to Virginians, where the company was headquartered, rather than West Virginians, and both Green and Baker understood that the operation would be non-union. ${ }^{103}$ The alliance between coal and environmental interests did not succeed in blocking Heartland, but it suggests that while some Lincoln Countians such as Jennings Midkiff might have responded to economic pressures and political changes in a xenophobic manner, others found ways to bridge gaps between themselves and persons of different backgrounds. Native/newcomer tensions in Lincoln County emerged, but they were ultimately negotiated, challenged, and at least partially broken down during the course of the debate.

Floyd Environmental Action Team: The Battle for Water Quality in Floyd County The energy crises of the 1970s that made surface mining attractive in Lincoln County had a rather different effect in Floyd. They shaped the ways in which alter-natives and locals in Floyd approached the issue of energy use and consumption. While back-to-the-land publications

\footnotetext{
102 The BCOA was an organization composed of coal operators that, in the 1950s, wanted to ensure a steady supply of coal for new markets, so they agreed to provide pensions for miners as well as a comprehensive health care plan in exchange for a no-strike pledge. Since the pension was derived from tonnage, it had the adverse affect of accelerating mechanization. Increased mechanization led to massive layoffs in the 1950s and 60s, and shifts to western (non-union) coal during the 1970s further eroded the BCOA contract. Pittston stopped paying into the BCOA pension fund in 1989. See Richard A. Couto, "The Memory of Miners and The Conscience of Capital: Coal Miners’ Strikes as Free Spaces,” in Fighting Back in Appalachia, 168-171, 173-175.

${ }^{103}$ Joe Farruggia, “Proposed strip mine has critics and supporters,” Lincoln Journal, October 10, 1990.
} 
were leading advocates for alternative energy development during the 1970s and early 80s, many Floyd Countians both native and new experimented with cost- and energy-saving measures. In 1977 Virginia's governor issued a mandate for the reduction of energy costs among all government offices and private businesses. Floyd businesses restricted their hours of operation to forty per week while county schools reduced thermostats to sixty-five degrees. ${ }^{104}$ Two weeks later the local newspaper published tips on how homeowners could reduce their energy consumption. ${ }^{105}$ The paper also profiled people who experimented with alternative energy sources. One native Willis resident, J.E. Bolt, reported that he successfully built a power generating system for his home on a nearby stream. A gristmill built by his grandfather in the late $19^{\text {th }}$ century served as his inspiration for the system and as a model for its construction. The system, he boasted, was able to fully power his home, which included "an air conditioner, washer and dryer, dishwasher, and hot water heater.” And with the "right equipment," he added, a similar system could provide "power for eight to ten homes." ${ }^{106}$ Then in 1979, the Floyd Press profiled Armen Showalter, who "built six experimental carburetion devices" for his cars that enabled him to nearly double his interstate mileage. ${ }^{107}$

Of all the local experiments and responses to the nation's energy problems, perhaps none was as successful and enduring as Luke Staengl's gasohol cooperative. In early 1980, the paper announced in a series of articles that the Federal Government had enacted measures to provide tax exemptions from the fuel tax to encourage the production and use of alcohol in gasoline. "President Carter," it reported, instituted an "88 billion dollar program to investigate the possibilities of synthetic fuel development concentrates on production of methanol from" sources

\footnotetext{
${ }^{104}$ Vona Weddle, "Businesses, Residents Respond to the Energy Crisis," Floyd Press, February 3, 1977.

105 "Energy Reduction Techniques Suggested to Va. Homeowners,” Floyd Press, February 17, 1977.

${ }^{106}$ Vona Weddle, "Willis Man Looks Upon Designing Own Power System as 'Challenge,'” Floyd Press, August 10, 1978.

107 Joan Townley, “Man Experiments with Gas-Saving Devices,” Floyd Press, August 16, 1979.
} 
such as coal and wood as well as ethanol from agricultural products. A week later, it announced local plans to create an ethanol still in the county: "Luke Staengl of Copper Hill received a grant in September of last year from the federal Department of Energy for \$19,300.” Staengl hoped that the still would foster regional energy independence and greater "self-sufficiency.”108

Luke Staengl's vision for energy independence in Floyd County and the New River Valley was born in the immediate context of the energy crises, but it also perhaps had roots that extended back to his early childhood years in rural Paraguay. He was born there, the son of German refugees who had fled Germany in 1937 due to Hitler’s rise to power. He described his parents as "pacifist” and as people who believed in "sharing wealth.” They initially sought refuge in England but were ousted in 1940 as part of Great Britain's efforts to expunge any threat of German spies. Staengl's parents were sent to Paraguay, one of the few nations willing to accept German refugees. They moved back to England in 1960 and stayed until 1964, when they migrated to the United States. ${ }^{109}$ After graduating high school, Staengl enrolled in a technical college in Pittsburgh in order to become a mechanic. He later took courses at the University of Georgia in order to learn how to manage corporations and agricultural co-operatives. Staengl was strongly against the Vietnam war; he registered as a conscientious objector and served as a health care worker in a hospital in lieu of being drafted. ${ }^{110}$

As a young adult, Staengl spent time in San Francisco where he became immersed in conversations about self-sufficiency and back-to-the-land ideology. He participated in Stephen Gaskin’s “Monday Night Class” meetings and began homesteading in Pennsylvania in 1971. He and his wife left their homestead in the aftermath of Hurricane Agnes and moved to The Farm in

\footnotetext{
${ }^{108}$ Chris Reilly, “Gasohol: Future Fuel,” Floyd Press, January 3, 1980; Chris Reilly, “Synthetic Fuel A Reality,” Floyd Press, January 10, 1980.

${ }^{109}$ Luke Staengl, interview by author, Morgantown, WV, November 27, 2011.

${ }^{110}$ Staengl interview.
} 
Tennessee. It was there that his awareness of problems associated with "farm waste disposal" grew. He investigated the research that had been conducted on energy and discovered that all of it had "leaned towards petro-chemicals and was funded by companies. With personal funds and on his own time," he began to explore "alternative methods of energy sources and treatment of wastes." ${ }^{111}$ Staengl's wife, who found life at the Farm to be unsatisfactory, prompted the couple to move. After a short stay on Long Island, and after Luke spent considerable time examining weather patterns and maps, the couple decided on Floyd. Between 1974 and 1979 he lived rentfree in a cabin in the woods and then finally purchased his farm in 1979. It was in that year that he also applied for the federal grant to start his alternative fuels program. ${ }^{112}$

Like the Floyd Mill Food Cooperative that was started around the same time, the fuel coop came out of the counterculture's utopian ethos. Co-operatives seemed to be the key to promoting "long-term nourishment" to the ills of society. In the face of failed social movements of the 1960s, these organizations had the potential to provide permanent structural change by offering an alternative to the dominant economic system. ${ }^{113}$ Even the Floyd Press recognized the connection between the county's growing countercultural population and the blossoming of cooperatives in the late 1970s and early 1980s. Writing about the fuel co-op in 1981, Beth Pratt commented, "In the late 60s, protest marchers set out to change the world by revolution and resistance, and to undo mistakes cultured by their predecessors." She noted that while the hope for revolution persisted, the approach had changed. "Today, years later, protests still exist for a cause, but some of those, who have endured through the earlier years of sign painting and critical label-throwing, have begun to work out viable systems which could actually revolutionize

\footnotetext{
${ }^{111}$ Beth Pratt, “Alcohol Fuel System Utilizes ‘Waste Not...Want Not,” Floyd Press, November 26, 1981.

112 Staengl interview.

${ }^{113}$ Craig Cox, Storefront Revolution: Food Co-ops and the Counterculture (New Brunswick, NJ: Rutgers University Press, 1994), 3.
} 
national, as well as world problems of trade deficit, pollution control, energy shortage, food production, dwindling resources, and rampant inflation.” Her example: Luke Staengl and his agricultural fuel co-op. ${ }^{114}$ Staengl believed that it could provide a measure of energy independence for small farmers struggling to make ends meet. It also reflected democratic ideals by affording members the opportunity to "have a direct influence on what policies are initiated and how the operation” was managed. ${ }^{115}$ But while it was an idea born out of the countercultural ethos, Staengl actively recruited local farmers to participate. His hope in 1980 was to have the plant service farmers "within a 10 to 15 mile radius" in order to "keep transportation costs to a minimum.” He accepted any crop residues, including “moldy grains” or other damaged products, as well as wood, sawdust, cornstalks, and other items. ${ }^{116}$ He also anticipated the creation of two permanent jobs with the opening of the facility and eventually as many as five in addition to the added financial benefits that cooperative members might reap. ${ }^{117}$

The Floyd County Agricultural Co-op was arguably the most successful attempt by alternatives to bring newcomers and natives together in a business setting up to that point. The food co-operative in Floyd opened in 1977, but for many years it predominately catered to in-migrants rather than locals. Staengl worked diligently to bridge the gap. In February of 1981, he, along with a man from nearby Rocky Mount, Virginia, who had been producing fuel alcohol, sponsored a demonstration to try to recruit farmers. He admitted at the time that they had only received guarantees of about 125 acres of corn for the operation, roughly half of what they needed to run the still at full capacity. ${ }^{118}$ In March, they sponsored their first annual Renewable

\footnotetext{
${ }^{114}$ Pratt, “Alcohol Fuel System,” Floyd Press, November 26, 1981.

115 James Hall, "Department of Energy Funds Floyd County Gasohol Producer," Floyd Press, July 24, 1980.

${ }^{116}$ Chris Reilly, "Synthetic Fuel a Reality,” Floyd Press, January 10, 1980. There were several food co-operatives proposed in Floyd during this time, including a vegetable co-operative that began with thirteen members in 1980. See Chris Reilly, "Vegetable Co-op Being Planned," Floyd Press, March 20, 1980.

${ }^{117}$ James Hall, “Department of Energy Funds Floyd County Gasohol Producer,” Floyd Press, July 24, 1980.

${ }^{118}$ Chris Reilly, “Local Alcohol Fuel Powers Tractor,” Floyd Press, February 5, 1981.
} 
Energy Benefit and Fair in order to promote the still and the broader goal of "regional energy self-sufficiency." ${ }^{119}$ The following month, Staengl joined Citizens for the Preservation of Floyd County, a grassroots organization campaigning against Appalachian Power's proposed hightension power line, and Joe Klockner, a local alternative energy expert, on Virginia Tech’s campus for an energy fair. ${ }^{120}$ In 1980, Staengl had formed a relationship with the University and received some equipment from the school's chemical engineering department, including “a distillation column, a condenser, and two gas-fired boilers for use in this and other plants in southwest Virginia." ${ }^{, 21}$ The condenser enabled the facility to produce as much as sixty gallons per hour as well as N-Butanol, which could be used as a diesel fuel for farmers’ tractors. ${ }^{122}$ Staengl's idealistic vision of a cooperative fuel enterprise met its fair share of challenges, even before operations began. The biggest obstacle may have come from oil producers who lobbied against alternative fuels and published damning studies that eroded public support for ethanol production. Staengl slowly built up his farm base, but he and the other owners had to overcome common misconceptions about ethanol. On February 21, 1980, the Floyd Press published an article that reflected concerns about the alternative fuel source. Citing its high evaporation rate, flammability, and corrosive qualities, one agricultural engineer interviewed for the article warned against its use. Staengl and another cooperative member, R.T. Butterworth, responded with letters to the editor correcting what they contended was misinformation. Staengl cited another study by engineers at the University of Nebraska that debunked many of the myths in the initial article. Butterworth offered a harsher criticism of the article by attacking the agricultural engineer, who he claimed worked for "special interests," meaning "the petro-

\footnotetext{
119 “Fuel Co-op Holds Fair,” Floyd Press, March 19, 1981.

120 “Energy Fair Set Sunday,” Floyd Press, April 30, 1981.

121 James Hall, “Department of Energy Funds Floyd County Gasohol Producer,” Floyd Press, July $24,1980$.

122 “Floyd Fuel Co-op Readies to Distill Alcohol,” Floyd Press, October 30, 1980.
} 
chemical industry." ${ }^{123}$ There were also concerns about reduced cropland for food production. But Staengl dismissed that idea as well, countering that the corn residues from the post-distillation process could be used as a high quality, high protein feed for cattle. ${ }^{124}$

After the fuel co-op began production, stabilization in oil prices also threatened the project. In another letter to the editor, Staengl thanked the many people who had been involved in getting the project off the ground but implored readers to join the enterprise: "We still need more members, who want to actively participate in the running of the co-op, and election of its officers. We need them NOW, even though there is an oil surplus and the price of gas seems to have stabilized, otherwise we may not be around when things in the Middle East come to a head again." 125

There was no local opposition to the ethanol plant, although there is some indication that locals were unsure about whether or not the operation would be successful and, if it was, what “newcomer” success might mean. In November of 1981 journalist Beth Pratt observed, “Two attitudes toward the alcohol fuel plant project have been 'they are sheiks on an oil well' and will act accordingly, or 'there's no way anything like that is going to work.'” Local reservations about the implications of success were not surprising given the alter-natives' increasing economic activity and, consequently, visibility in the community. Between 1979 and 1981 dozens of articles appeared in the Floyd Press profiling the county's new wave artists, musicians, business owners, entrepreneurs, and farmers. Their increased presence did not always translate to warm welcomes. In the midst of community debates over funding for education and a dramatic increase in local marijuana production that attracted the unwanted attention of the Washington

\footnotetext{
${ }^{123}$ Luke Staengl, “Myth vs. Fact,” Floyd Press, February 28, 1980; R.T. Butterworth, “Shock and Amazement," Floyd Press, March 6, 1980.

${ }^{124}$ Chris Reilly, “Local Alcohol Fuel Powers Tractor,” Floyd Press, February 5, 1981.

${ }^{125}$ Luke Staengl, “Enormous Contribution,” Floyd Press, December 3, 1981.
} 
Post, a significant degree of local resentment toward newcomers surfaced in the paper. Value clashes appeared to be at the root of the conflict, although alter-natives' increasing involvement in community issues also played a role. ${ }^{126}$

Funding was a consistent challenge for the company. Research and development began in 1979 with a \$19,300 grant from the federal Department of Energy's appropriate technology program. That program typically provided "up to $\$ 10,000$ for research or investigation of alternative energy sources and up to $\$ 50,000$ for technological development." ${ }^{\prime 127}$ The equipment donated by Virginia Tech was valued between $\$ 80,000$ and $\$ 90,000$. And along with recruiting local support from farmers, Staengl also invited Floyd County residents to purchase corporate notes, or loans, that offered lenders ten percent interest on their investments. ${ }^{128}$ In late 1981, the local paper reported that the co-op had also received additional federal monies through Virginia Tech to explore the possibility of using methane digesters in the operation. ${ }^{129}$ They also received additional loan money from the newly created National Consumer Cooperative Bank, a federal program that provided loans for a variety of cooperative enterprises. One of the bank's missions was to provide money to low-income areas like Floyd. The money was used "to finance equipment and to provide working capital” for the operation. ${ }^{130}$

State tax incentives helped, but those too were precarious. Virginia’s General Assembly passed the incentives in 1981, which gave an eight-cent per gallon break to encourage the production of gasohol. At the time, the state provided generous support for such initiatives. The original idea was to allow the incentives to help develop ethanol in the state to promote energy independence. It was a graduated tax break that eventually would reduce the rate to six cents per

\footnotetext{
126 This topic will be explored in depth in Chapter 6.

${ }^{127}$ Chris Reilly, "Synthetic Fuel a Reality,” Floyd Press, January 10, 1980.

128 James Hall, “Department of Energy Funds Floyd County Gasohol Producer,” Floyd Press, July 24, 1980.

${ }^{129}$ Beth Pratt, “Alcohol Fuel System,” Floyd Press, November 26, 1981.

130 “Fuel Cooperative Gets Loan From Co-op Bank,” Floyd Press, December 10, 1981.
} 
gallon in 1986 and then two cents thereafter until 1992. In response to the late 1970s energy crisis, the tax had been passed unanimously in the Senate and passed by a wide 79-19 margin in the House. Reflecting mid-decade budget cuts and dramatic reductions in oil prices, however, Virginia Senator Edward Willey, chairman of the Senate Finance Committee, sought instead to focus money on highway development. Rather than following through with a graduated decline in the ethanol tax incentive, which would have been set to expire in 1992, he proposed immediate revocation in early 1986. Staengl, who had become the president of the Virginia Ethanol Association, declared that the Senator's action would effectively "destroy" the ethanol industry.

Lobbying and an intense letter writing campaign on the part of Floyd residents hopeful to continue the tax breaks staved off Willey's proposal, but not without sacrifices. Ethanol producers continued to receive the breaks, albeit with ceilings imposed on the amount of taxexempt fuel. And consumers had to pay more to make up for the difference. This, combined with much cheaper gas prices, hurt ethanol producers. Communications Director Bill Kovarik, explained, “ 'We give the service stations about a penny extra profit over gasoline. When their profit margins are only three or four cents a gallon, that looks pretty big. But they have the biggest profit margins ever right now, about 20 or 30 cents a gallon, so the extra penny they can make on gasohol doesn’t look all that big.”'131 To stabilize the company in the face of financial pains, the shareholders voted in 1985 to shift from a cooperative to corporate model. ${ }^{132}$

In spite of the odds, the Floyd Agricultural Fuel Corporation enjoyed a brief period of expansion. Alter-native Kamala Bauer, who had been hit by a drunk driver in December 1984, had just received health insurance through the company for the first time. "They actually became

\footnotetext{
${ }^{131}$ See, Roger Mannon, "State legislation endangers local gasohol industry,” Floyd Press, February 6, 1986; Roger Mannon, "Letters, lobbying preserve state’s gasohol industry," Floyd Press, March 20, 1986.

${ }^{132}$ Wanda Combs, "Plants of controversy: opposition not majority, officials say,” Floyd Press, June 6, 1991.
} 
worth something," she recalled. "For about two years it actually worked."133 Part of that came from their reliance upon a company in Tennessee that produced excess candy. Ethanol from agricultural products used a lot of gasoline, a reality that troubled industry supporters. "You grow corn and then you make fuel. Doesn’t that seem smart?” remarked Bauer. “But the thing is, is it takes a lot of gas to grow corn.” So the company began relying in part on excess candy to make fuel. At the height of production, they even had a local gas station to sell their product. "We grew our corn and excess waste candy and we made gasoline, ethanol, to add to gasoline and we had our own gas station for a little while.” By February 1987, there were two ethanol plants in operation that collectively employed sixty-seven people, many of whom were native Floydians. And shareholders hoped that with additional investments of up to \$1.5 million dollars for a new facility that would conduct research and produce ethanol from wood, they would be able to hire nearly double the number of people. ${ }^{134}$

Concerns about the energy that it took to create ethanol out of agricultural products, coupled with the tenuous nature of state and federal support for such initiatives, prompted Staengl to want to diversify his operations. Company officials announced plans to explore new processes in the spring of 1986 while discussing the recent threat of the elimination of tax breaks. Staengl founded a sister company called Bio-Regional Energy Associates, Ltd., or BREAL, that was initially intended to conduct research on how to convert "low value materials such as wood chips into high value products.” As the Floyd Press described it, the process involved feeding hardwood chips into a "Stake gun," which would then convert the wood into "a fluffy brown fiber from which cellulose, hemicullose and lignin can be readily extracted. Those elements, in turn," could be "converted into a whole host of valuable products including ethanol,

\footnotetext{
${ }^{133}$ Bauer interview.

${ }^{134}$ Mannon, “State legislation endangers”; Roger Lewis, "B-REAL assures: Research project will not pollute air,” Floyd Press, February 5, 1987.
} 
artificial sweeteners, and solvents.” The "fractionation” process, as it was called, began in October of 1987, and it was to be the only facility in the United States with that particular technology. ${ }^{135}$

Almost immediately, local residents voiced concern over the new operation. Some worried that the facility would emit odors similar to the paper and pulp processing plants that dotted the Appalachian Mountains. Staengl and B-REAL's general manager Thomas C. Bowden defended the project, insisting that by engaging in recycling of unusable products and supporting the local economy by providing jobs, they were being good community stewards. They hoped to "turn things ... regarded as waste and pollutants into products which are useful and less harmful to the environment.” Answering the question about odors from pulp processing, Staengl asserted that the familiar "rotten egg" smell came from sulfuric acid, a chemical that his operation would not use. The wood fractionation process used steam instead. ${ }^{136}$

In spite of initial reservations about air quality, there was still a generous outpouring of support for both the ethanol plants and for B-REAL's expansion into research and development. The Floyd County Board of Supervisors demonstrated unwavering support for the projects. It threw its weight behind the companies during the tax debacle by drafting a resolution that was submitted to the state senate. ${ }^{137}$ Permits generally sailed through with little controversy, and the state even approved \$300,000 in its budget for the Center for Innovative Technology at Virginia Tech to explore uses for wood by-products. ${ }^{138}$ Virginia Tech, in turn, partnered with B-REAL to

\footnotetext{
${ }^{135}$ The Stake gun was named after the Canadian company, Stake Technologies, that developed it. Floyd Press reported at this time that only two others existed in the world, and they were located in Finland and France. But it later reports that France is the only other location (see below). Roger Lewis, "B-REAL schedules stock sale," Floyd Press, October 1, 1987; Roger Lewis, "Chips to Riches wood conversion activated," Floyd Press, November 5, 1987.

${ }^{136}$ Roger Lewis, “B-REAL assures: Research project will not pollute air,” Floyd Press, February 5, 1987.

${ }^{137}$ Wayne Bradburn, "Thanks for your support," Floyd Press, February 20, 1986.

${ }^{138}$ Roger Lewis, "B-REAL eyes role in research,” Floyd Press, June 25, 1987.
} 
conduct the research in its new facility. ${ }^{139}$ The project also attracted the attention of national and world leaders who were interested in exploring some of the same technological processes. In late July of 1987, Virginia Representative Rick Boucher accompanied French Assembly member Michel Jacquemin as they toured B-REAL's facility. He described the facility as "one of the most interesting single industrial projects we have today in Southwest Virginia.” Jacquemin was interested because the only other fractionation facility in the world was located in Soustons, France. France had also been a leader in ethanol technology, having produced the "petrol verte" as early as the 1920s. Boucher saw in fractionation the possibility too of strengthening southwest Virginia’s hardwood industry, specifically mentioning his hope that reforestation of formerly strip mined mountains could serve the new technology. ${ }^{140}$

There seemed to be significant local support as well. In early 1987, newcomer Kathryn DeLauney wrote a letter in response to an earlier article reporting on the county's pristine air quality. She cautioned readers that they would have to actively work to maintain that attribute, and she praised the county's “forward-thinking management of new and old industry" for taking “the necessary steps.” She specifically cited the relationship between the twin companies, the Floyd Agricultural Energy Corporation and B-REAL, and Virginia Tech for working diligently to "help solve pollution problems like the pouring of raw sewage into the creeks and rivers ... and the proper disposal of oil and diesel waste fuels.” "There are appropriate systems," she added, such as "methane digesters, filters and recycling . . . that could responsibly solve such

\footnotetext{
${ }^{139}$ Roger Lewis, “Rep. Boucher, French visitor tour B-REAL,” Floyd Press, July 30, 1987.

${ }^{140}$ With the possibility of an increased regional demand for hardwoods coming from fractionation, Boucher entertained the idea of "exempting [formerly surface mined] lands from being put back" to their original contour "if it is possible to use those lands, as they now lie, for a higher commercial use.” This would have directly challenged President Carter's Surface Mining Control and Reclamation Act of 1977. Boucher pitched the idea to Representative Morris K. Udall, chairman of the House Interior and Insular Affairs Committee. The implications of weakening the Act for special circumstances were apparently not lost on Udall; he realized that he would have to "proceed cautiously to prevent any gutting of the reclamation program's main intent during the legislative process." See Lewis, "Rep. Boucher."
} 
problems.” She then encouraged the community to continue supporting the local leaders with technological "know how": "We, as a county, should help our citizenry implement the wise practices needed to secure the quality of the environment. And our county government should hold this among its highest priorities."141

In the spring of 1988 things appeared rosy for the nation's ethanol industry. In April the Senate passed legislation, which had been approved by the House in December of 1987, that would encourage automakers to produce more vehicles equipped to run on alternative fuels. The bill's supporters were an unlikely mix of senators from agricultural states, those suffering from high levels of smog, and those, like West Virginia, "with other resources for producing nongasoline fuels-resources such as natural gas and coal.” The House and Senate had yet to come to agreement on the exact terms of the bill, and they also needed President Reagan’s signature. ${ }^{142}$

But only a few short months later, while the bill was still pending, financial problems forced B-REAL (not FAEC) to eliminate its ethanol production. The Floyd Press reported that the decision came from a combination of factors: "the low cost of gasoline, trimming of federal and state alcohol fuel incentives and the cost of corn-based feedstocks for making ethanol.” Staengl and his staff asserted that they would continue to research "alternative products" and hoped to find something quickly enough to "begin producing one of those options" and to avoid layoffs. But, as the paper noted, "the return on investment in that research may be years away,” so B-REAL scrambled to find something that could keep the facility running. ${ }^{143}$ In late 1989 the plant announced a new research and development partnership with Virginia Tech that would last four years, which eased the financial burdens on that portion of the business. But it also

\footnotetext{
${ }^{141}$ Kathryn DeLauney, “Maintain Our Environment,” Floyd Press, February 19, 1987.

142 Roger Lewis, "Senate legislation boosts use of alternative fuels,” Floyd Press, April 28, 1988.

${ }^{143}$ Roger Lewis, "Ethanol maker weighs alternative products,” Floyd Press, July 7, 1988.
} 
announced that it would begin to "gather cash flow by recovering water-free, high value solvents from used antifreeze and other products.”144

Meanwhile, between 1988 and 1989, there had been a growing movement among some Floydian alter-natives to raise awareness about groundwater and other types of pollution. The first threat came from the County Board of Supervisors’ proposed ordinance in early 1989 to fine landowners who allowed the invasive plant multiflora rose to take root on their property. They were concerned that it would rapidly spread to the county's pastures and croplands. The Board's proposed solution was to force any landowner who spotted the plant to eradicate it with pesticides and herbicides, including 2, 4-D, an ingredient found in Agent Orange. Katherine DeLauney, Will Bason, and other alter-natives protested the ordinance, arguing that pesticide use on a county-wide scale would cause groundwater pollution and would ultimately be ineffective in eradicating the plant. They formed the Floyd County Council on the Environment, which later became the Floyd Environmental Council, "to address the issues of herbicide and pesticide use in the county." The group held meetings to figure out how to address concerns about groundwater contamination and they hosted speakers like Eric Umstead, the Director of the Agricultural Resource Center in North Carolina, to educate the public on pesticide and herbicide use. ${ }^{145}$

The issue calmed somewhat as reports came out that the multiflora rose was succumbing to a mite that attacked both the roots and stems of the plant. ${ }^{146}$ But concerns about protecting the groundwater continued into the second half of the year as the county discussed revising its 1981 landfill ordinance. The issue began as Allegheny County announced its plans to close a private

\footnotetext{
${ }^{144}$ Roger Lewis, "B-REAL, Tech combine forces for research,” Floyd Press, December 12, 1989.

${ }^{145}$ Nancy M. Barnhardt, "Prevent Any Risk to Groundwater,” Floyd Press, January 12, 1989; Barnhardt, "Paying People to use Herbicides,” and Will Bason, “Referendum Needed?” Floyd Press, January 26, 1989; “Council formed to address chemical issue,” Floyd Press, February 2, 1989; Kathy DeLauney, “Got to be a better way,” Floyd Press, February 2, 1989; “Environmental Council sets public forum,” Floyd Press, March 23, 1989.

146 Roger Lewis, “Nature targets multiflora rose,” Floyd Press, March 2, 1989.
} 
landfill that had received garbage from as far away as New York City. Much of the New River Valley would have been excluded from alternative dump sites because of the nature of the limestone rock formations that allowed easy seepage into the groundwater. But the southern part of Floyd County, with heavy clay soils and shallower valleys, was more suitable for landfills. ${ }^{147}$ The Floyd Environmental Council mobilized once again to ensure that the ordinance was revised to make it nearly impossible for landfills to be opened there. A public hearing was held on Monday, October 9, 1989 to discuss revisions. "Many of those attending," noted the local paper, "settled in Floyd from elsewhere," and they had many recommendations for preventing landfills in the future, including revising ordinance language to have "more 'shalls' and less 'mays' because although present board members are 'good people' their successors 'might be scoundrels,"” warned Ed Broderick. ${ }^{148}$ The county adopted the new ordinance in late October of 1989. ${ }^{149}$ Toward the end of 1990, there was yet another debate about whether or not Floyd County should become part of a regional landfill. All thirty-five people who attended a public hearing on the issue on November 20, 1990 spoke out against the proposal. In early 1991, the Floyd County Board of Supervisors voted four to one to keep the landfill local with the provision that they might eventually decide to accept participation with the regional system should costs become prohibitive. ${ }^{150}$

These initiatives demonstrate that there was already a strong grassroots effort to protect Floyd County's groundwater by the time the Floyd Agricultural Energy Corporation announced

\footnotetext{
${ }^{147}$ Roger Lewis, “Landfill ordinance reviewed,” Floyd Press, June 29, 1989.

${ }_{148}$ Roger Lewis, "Citizens want strict controls," Floyd Press, October 12, 1989.

${ }^{149}$ Roger Lewis, “Tough landfill ordinance passed,” Floyd Press, November 2, 1989. The ordinance included the following restrictions: landfill operators would have to have a one million dollar insurance policy for environmental damages; any proposed landfill would first require a public hearing; landfills could not be placed within 500 feet of churches, hospitals, schools, homes, or parks; and operators would only have five days, instead of thirty, to address citations.

${ }^{150}$ See Roger Lewis, “Keep our landfill, Floyd County citizens urge,” Floyd Press, December 6, 1990; Roger Lewis, "Board backs local landfill...for now,” Floyd Press, January 17, 1991.
} 
its intention to partner with a Louisiana chemical company, NovaChem, to recycle chemicals. Citing the company’s ongoing financial troubles and its immediate need to get out of debt, Staengl asserted that the decision was a strategic move to keep the company alive. Not all shareholders agreed. The Floyd Press cited one unnamed stockholder, possibly Kamala Bauer, who said she was shocked by the news of the transition. "She said that she was an environmentalist first and one of the goals in organizing FAEC was to make it a safe place to work and to live around.” Her opposition was also based on the notion that "chemicals traveling the winding country roads” could threaten local citizens and groundwater in the event of spills. ${ }^{151}$ Operating through the Floyd Environmental Action Team, she and others galvanized their efforts to stop FAEC’s plans from moving forward. ${ }^{152}$

Within a matter of weeks dozens of people wrote to the paper to express their concern and demand more information. Nancy Barnhardt, a vocal figure in the movement against pesticides two years earlier, was the first person to write regarding the issue. "What are the names of all the chemicals which FAEC has handled in the past year and do the employees who work with them consider them hazardous?” she asked. She wondered how FAEC would “maintain control” of operations if it were “taken over by an out-of-state company?” And forecasting one of the major concerns of the movement against the corporation, she called for an investigation of NovaChem’s record toward the environment in Louisiana. ${ }^{153}$ Mary Day, who proclaimed that she had chosen to live in Floyd "because of its beauty, its wonderful people, and especially because of its clean environment," asked similar questions about the nature of the

\footnotetext{
${ }^{151}$ Wanda Combs, “Company looks for help from La. chemical firm,” Floyd Press, January 24, 1991.

${ }^{152}$ Bauer interview. Regarding the formation of FEAT, it is unclear whether the earlier Floyd Environmental Council became the Environmental Action Team or if a completely new organization formed.

153 Nany Barnhardt, “Deserves More Information,” Floyd Press, February 7, 1991.
} 
chemicals, assurances for their safe storage and transportation, and FAEC's "past and present safety record concerning the leakage of pollutants into the environment.”154

At least one person writing to the paper about the recycling plant was not a Floyd resident; rather, he was considering moving to Floyd because of its growing reputation as a countercultural hot spot with a pristine environment. Lanny Bean, who was in the process of leaving his homestead in Spencer, West Virginia, because of “chemical pollutions,” asserted that he was “first attracted to” Floyd "because of its pristine condition, as well as its wonderful people.” But the threat from FAEC's chemical recycling facility had forced him to reconsider the move: “This will influence my decision because I am giving up my beautiful farm in West Virginia due to chemical pollutions. I am looking for a community that would appreciate environmentally sound industry, not a target community for chemical processing, waste incineration, mega dumps, etc." ${ }^{155}$ Other Floyd in-migrants warned that if the county fell prey to outside corporations, people would no longer be attracted to the area. "Remember that many people are attracted to Floyd Co.,” wrote Barbara Harich, “in part because of the absence of industry and because they believe that progress is not always synonymous with growth.”156 “Why do folks passing through marvel so at what we have here?” asked Jeffrey Founds. “I think I know why: I think it is because others are reminded of the past, when things were not so rushed, greed and industrial pollution were not so prevalent and one could still trust his neighbor." "It takes love to nurture what we have here and strength to keep it that way, and our choice of what industries we do or do not allow in our county is directly related to our tourist trade.”157

\footnotetext{
${ }^{154}$ Mary Day, "We Owe Our Chidren,” Floyd Press, February 14, 1991.

${ }^{155}$ Lenny Bean, “Doesn’t want target community,” Floyd Press, March 7, 1991.

${ }^{156}$ Barbara Harich, "Your Opinion Counts," Floyd Press, September 16, 1997.

157 Jeffrey Founds, "Why People Come Here," Floyd Press, March 14, 1991.
} 
One of the biggest concerns was the outside management of FAEC. Like the Lincoln County anti-strip mine activists, Floyd County's environmentalists were alarmed at the prospect of having non-local influence over an enterprise that could potentially affect environmental quality. Mary Day wrote, “The stockholders of FAEC are being asked to approve a practically foregone conclusion of increasing dealings with NovaChem and increasing NovaChem's power in the company.” That same day, Michael Dalber voiced a similar opinion: “I can’t help but feel concerned and anxious over the proposal of a Louisiana-based company coming into Floyd County and taking controlling interest in FAEC ... Too often we read and hear about communities adversely affected by the disregard of commerce to their well-being." ${ }^{158}$ Isa Graefe asserted that she had once supported "The Still," but she questioned the move to allow an outsider to control a potentially risky operation. "I have to assume it is a typical, hard core operation that routinely ships, processes, and somehow disposes of mass quantities of highly toxic substances. I also assume under Bob Farmer [NovaChem’s president], who lives nowhere near Floyd, the new operation will be without the scruples and integrity we trusted in Luke Staengl., ${ }^{159}$ Catherine Founds, who lived near the corporation’s original plant, criticized it as an "eyesore," and charged that although she had at one time overlooked the plant's appearance because she believed "progressive people were in charge," she had grown fearful that a "faraway, inaccessible chemical broker” was going to take control. Unlike Graefe, she took a jab at FAEC management, distinguishing between them and the county's "many true environmentalists” who would "continue to watchdog threats to our sensitive environment." 160

\footnotetext{
${ }^{158}$ Day, “We Owe Our Children,”; Michael Delber, “What About the Future?” Floyd Press, February 14, 1991.

${ }^{159}$ Shay DuRon, "Looking for a solution," Floyd Press, February 28, 1991; Isa Graefe, "Take a stand for protecting our home,” Floyd Press, February 28, 1991.

${ }^{160}$ Catherine A. Founds, “Appearance Puzzling,” Floyd Press, February 21, 1991.
} 
Several people, while concerned about the plant's trajectory, still respected Staengl's environmental sensibilities and acknowledged that as long as he maintained control, the business could be trusted. A recent arrival to the community, Shay DuRon, was concerned about the issue but advised readers to take the time to talk to Staengl, a man he believed was "very willing to accommodate the community in coming up with a plan to salvage his company and keep everyone happy.” He recommended that local residents “help by either talking to Luke personally, writing a letter," or starting "an Open Forum” in the paper "for the community to tap into specific issues.” ${ }^{\text {161 }}$ Chris Prokosch was less forgiving in his assessment of the outcry. He listed the many ways in which Staengl's companies had addressed important environmental concerns, including “wind powered electric generation, solar panels, methane generation,” and more, but added, "No, pollution in the form of misinformation and self-righteousness (whatever the motive) is threatening with extinction the only companies in our area to risk pursuing a longterm commitment to improving the environment.” 162

The intense letter writing campaign to the Floyd Press, which continued unabated until the last week of April 1991, ended when the paper announced its decision to stop publishing them because of the "volume and nature of letters concerning B-REAL and FAEC." The editor released one final rebuttal to an earlier letter that had illustrated what the writer believed to be twin companies’ questionable past. FAEC’s general manager, Stephen Byler, disputed allegations that the death of a truck driver hauling gasoline "had anything to do with" the company's health and safety record. He noted, however, the level of "distress" that people at the company had felt regarding the outcry against their chemical operations, adding that there were "various different concerned groups of people, with different agendas regarding FAEC and B-

\footnotetext{
${ }^{161}$ Shay DuRon, “Looking for a solution,” Floyd Press, February 28, 1991; Isa Graefe, “Take a stand for protecting our home," Floyd Press, February 28, 1991.

${ }^{162}$ Chris Prokosch, “Threatening With Extinction,” Floyd Press, March 14, 1991.
} 
REAL." "We share the interest of those who advocate developing a forum for reasonable dialog," he continued, "and share their concerns regarding the continuation of these facilities and their activities.” But the other group of activists, he charged, an "obviously much smaller group whose only objective appears to be complete and permanent closing of both facilities,” has "resorted to tactics which involve spreading hysteria, fear, distortions, divisiveness and sadly, outright deceptions.”163

Distortions and misinformation might have circulated in the community as a result of the conflict, but there were legitimate health concerns that came to light as the drama unfolded, which generated additional negative publicity for the twin companies. The Floyd Press revealed that the B-REAL facility had problems stemming from an antifreeze recycling contract they had entered with the Radford Army Ammunition Plant. The contract was "lucrative" for the financially vulnerable business, generating $70-80 \%$ of its income, but because the plant was not allowed to distribute waste into local streams, it had to evaporate water and, along with it, "low levels of diethylene glycol,” one of the primary ingredients in antifreeze. People living in the vicinity of the plant complained about stomach and respiratory ailments, rashes, and other health problems, enough that the plant closed in March 1991 to evaluate the issue. In larger cities with municipal water services, explained executive vice president Tom Bowden, that type of wastewater could be treated. But Floyd did not have the infrastructure to be able to handle the waste. Bowden admitted that the water problem was the company’s “Achilles heel.” The plant closed its recycling operation in March and by late May faced foreclosure. ${ }^{164}$ As of June 1991, B-REAL was unable to deal with the emissions problem because it lost the Radford Army

\footnotetext{
${ }^{163}$ Stephen Byler, “Increasing Distress,” Floyd Press, April 25, 1991.

164 "B-REAL will shut down temporarily," Floyd Press, March 14, 1991; Wanda Combs, "B-REAL facing foreclosure; bank asks for debt payment," Floyd Press, May 30, 1991. The plant did, however, continue research and development. See "B-REAL plans new venture,” Floyd Press, August 15, 1991.
} 
contract once word spread about the health issues. And the "last load of fuel alcohol," reported the Floyd Press, "left FAEC . . . on May 16." The result was a reduction of the workforce and workweek from five to four days. ${ }^{165}$

NovaChem's acquisition of FAEC rested on whether or not a two-thirds majority of stockholders approved the plan. Either way, reported Staengl, the corporation would have to move forward with some form of partnership in order to survive. "If the NovaChem deal is approved,” explained the newspaper, NovaChem CEO Bob Farmer “will receive 40 percent of the shares and will be given one seat on the seven member board of directors. If shareholders don't approve the union with" the company, "it will be up to Bob Farmer as to what to do because FAEC is in default of its loan.” Staengl concluded that if Floyd wanted to maintain some level of input in FAEC's future, they should "work with existing management . . . and not ... dislodge us, defame us, and put us out of the driver’s seat." 166

Staengl, Byler, and Bowden continued to defend the companies through the summer, targeting the Floyd Environmental Action Team as NIMBYs who did not understand the dire need for recycling facilities that could handle automotive and other types of industrial wastes. “Not in my back yard is an attitude that harms recycling efforts as a whole," said Staengl. Bowden and Staengl added that a general lack of participation among the shareholders had resulted in some of them being “caught . . . off guard” by the NovaChem proposal. They should not have been, said Staengl, because "for the last three years . . . the board of members was told

\footnotetext{
${ }^{165}$ Wanda Combs, "Plants of controversy: opposition not majority, officials say," Floyd Press, June 6, 1991. BREAL had attempted to recycle various other chemicals, several of which resulted in bad odor emissions. Combs reported in the same article that the plant had recycled ethanol, which resulted in a sulfur smell, and ethylene glycol, which likewise produced an unpleasant odor. The latter program would have been profitable, and B-REAL management insisted that it was safe. FAEC engaged in chemical recycling as well. That facility processed acetic acid and industrial alcohol.

${ }^{166}$ Wanda Combs, "Plants of controversy: opposition not majority, officials say."
} 
the company was going to have to look at other options and those options would involve other corporate entities.”167

Throughout the summer and into the fall, the Floyd Environmental Action Team, which included several of FEAC's board members, pressed the Floyd County Board of Supervisors for measures to control hazardous materials in the county. They started in June by presenting the board with a petition bearing 350 signatures that called for a "public hearing on controlling hazardous waste from local industries.” The board responded by insisting that the hearing would be irrelevant without an ordinance. They promised, however, that they would investigate the possibility of an ordinance but were unsure whether or not they could pass one under the state's Dillon Rule. ${ }^{168}$

It is clear from reports of the public hearings that both natives and newcomers were involved in efforts to keep chemical recycling out of the county. Clay Vest, for one, protested the rollback of the 1989 ordinance by declaring that while he was "not a hippie,” the issue of hazardous waste was something that should be viewed as “a potential problem for all of us.”169 But there was a general sense in the community that a majority of activists were alter-natives. This was captured in a letter from Isa Graefe, who asserted, "I’ve heard a lot of people say that this is a hippie issue.” It may have been, but, she noted, a majority of the in-migrants were “unwilling to get involved." "170

Prior to 1992, although emotions had run high at points over the twin companies’ problems and transitions, relations remained fairly civil in Board of Supervisors meetings and in

\footnotetext{
${ }^{167}$ Wanda Combs, “Plants of controversy: environmental, safety concerns,” Floyd Press, June 13, 1991.

${ }^{168}$ Roger Mannon, "FEAT seeks hearing for hazardous waste,” Floyd Press, June 20, 1991.

169 Mannon, “FEAT urges,” Floyd Press, February 20, 1992.

${ }^{170}$ Isa Graefe, “It’s Worth Fighting For,” Floyd Press, January 30, 1992. In 1989, the paper noted that during a hearing on the landfill, "many of those attending settled in Floyd from elsewhere, but there were natives there, too." Roger Lewis, “Citizens want strict controls,” Floyd Press, October 12, 1989.
} 
the newspapers. It appeared, as Graefe observed, that community divisions were generally, although not exclusively, confined to the alternative sub-community. True native/newcomer distinctions during the chemical recycling debate only clearly emerged after an alter-native named Warren Kimmel proposed a hunting ban in the county. ${ }^{171}$ The "Comments” section of the Floyd Press exploded with responses from angry natives who lambasted the man’s recommendation. They censured him for his lack of understanding of local culture and limited appreciation for "individual rights and freedoms." “It looks to me like you need to be educated on common sense country living and less in higher educated living,” vented county native Ralph Poff. ${ }^{172}$ Launching an attack on Kimmel's observation that the county had grown too much to continue to allow hunting, Charles L. Wilson retorted, “Maybe we should ban immigration. ‘All roads lead to Floyd County.' Well, look over your shoulder when you drive into the county. 'All roads also lead out.",173

Most responses to Kimmel directly confronted the hunting ban or broader perceived threats to cultural heritage, but a few writers suggested that the in-migration of homesteaders, retirees, and other rural-life seekers had taken its toll on community relations. In a short response to Kimmel’s letter, Timothy Vest vented, “I’m really tired of people moving into Floyd County and then trying to run everything. You didn’t like where you lived so you move here and then try to change our way of life.” He cited their protests against hunting, ridiculed them for opposing logging yet living in timber frame homes, and mocked them for supporting "recycling but when a company wants to recycle, you are against it. You use just as much gas, oil, and yes,

\footnotetext{
${ }^{171}$ Warren H. Kimmel, “Is It Worthwhile,” Floyd Press, December 26, 1991; Warren H. Kimmel, “Carry On Men,” Floyd Press, January 9, 1992.

172 Bob Morris, “Hunting Rights,” Floyd Press, January 2, 1992; Ralph Poff, “Native Hunter,” Floyd Press, January 2, 1992;

${ }^{173}$ Charles L. Wilson, “All Roads Also Lead Out,” Floyd Press, January 9, 1992.
} 
antifreeze,” he added, “as anybody else!”174 Some of the alter-natives who wrote letters

following the hunting controversy retorted that they had a right to live in the county and have a political voice. Isa Graefe remarked, “I wasn’t born or raised here. But I didn’t come here to change Floyd County. I came because I like it the way it is, and to me it’s worth fighting for.”175 Others like Anne Armistead used the conflict over hunting to try to find common ground between the two groups. "I was moved by the depth” of the hunters' "pride and their righteous anger at the suggestion of having their rights (in this case to hunt) taken away. To me these letters were a vivid portrait of the strength of the people who live here.” She attempted to connect their own notions of personal rights and freedoms with the "freedom to preserve quality of life.”176

The hunting controversy did not diminish the Floyd Environmental Action Team’s efforts. But while board members appeared receptive to their requests, there were signs that some of the members tacitly supported the chemical recycling. County Attorney Marc Small repeatedly insisted that a 1989 solid waste ordinance did not apply to B-REAL's activities, and another attorney remained vague about what measures the county could take to restrict hazardous waste. Environmental attorney Greg Haley, whom County Administrator Randy Arno hired as a consultant for the controversy, suggested in August that there were three points that might affect the company: whether or not it had all of the necessary permits to manage hazardous or solid wastes, whether the ordinance actually applied to B-REAL since it did not necessarily deal with solid waste, and whether the ordinance could even regulate the business at all. The attorney

\footnotetext{
${ }^{174}$ Timothy Vest, “Tired of People Trying to Run Everything,” Floyd Press, January 23, 1992.

${ }^{175}$ Graefe, "It's Worth Fighting For." Emilia Martinez-Brawley notes that the tension between newcomers and oldtimers typically boils down to anxiety about the changing identity of the small community. In the case of the hunters, they perceived the proposed hunting ban as an attack on a practice that had deep roots in the region and, as such, had helped to shape their identity as a people connected to both family tradition and the local landscape. See Emilia E. Martinez-Brawley, Perspectives on the Small Community: Humanistic Views for Practitioners (Silver Spring, MD: National Association of Social Workers Press, 1990), 146.

${ }^{176}$ Anne Armistead, "Freedom is at Stake,” Floyd Press, January 9, 1992.
} 
added that it was uncertain if the company was "involved in pure recycling" and "if the company was disposing of solid or hazardous wastes." ${ }^{\text {177 }}$ Options had become clearer by October; they could issue a cease and desist to B-REAL's receipt of hazardous materials, launch "further investigations ... decide the ordinance does not apply to the companies," or relegate to the state "the problem of deciding how to deal with waste from local industries." ${ }^{178}$ The board chose the last option.

Then, in late November, the Floyd Environmental Action Team protested what they felt was a "cowardly act" by some of the outgoing board members who decided to propose revisions to the 1989 ordinance that would actually make it easier for companies like B-REAL to operate. Two members proposed that liability insurance, transportation fees for hauling waste in and out of the county, and emergency response plans be eliminated. Marc Small admitted to having suggested the changes "after going back to his notes from 1989, when the ordinance was crafted and passed.” He and the others who supported the revision believed that the ordinance was only written to apply to landfills and not to industry. ${ }^{179}$ Several activists complained that Small should have had no say in the matter since he had, at one time, excused himself from the B-REAL controversy on the grounds of conflicts of interest. Ruth Steinberger wrote, "Our county attorney, Marc Small, who had earlier disqualified himself from this issue based on a conflict of interest, is now working to reword the ordinance so the chemical waste plants will not be covered by the ordinance. Where did his conflict of interest go?"180 "Like thieves in the night," wrote another person, “they omit from ‘approved minutes’ important matters as the admission of

\footnotetext{
${ }^{177}$ Roger Mannon, “Supervisors urged to get information on chemical plants," Floyd Press, August 15, 1991.

${ }^{178}$ Roger Mannon, "Board passes waste issue on to state," Floyd Press, October 24, 1991.

${ }^{179}$ Roger Mannon, “Citizens protest board’s handling of ordinance,” Floyd Press, November 21, 1991; Isa Graefe, “Serving Industry Interests?” Floyd Press, November 21, 1991.

${ }^{180}$ Ruth Steinberger, “Wondering,” Floyd Press, December 5, 1991.
} 
a conflict of interest with the county attorney from whom they are taking ill found advice, even though State Law requires 'complete minutes.’”181

Before the year's end, the Board “voted unanimously to delete the \$20/ton transportation fee . . . and voted 4-1 to clarify the ordinance's applicability to private landfills.” The board's decision to weaken the ordinance was likely influenced by the interest of another outside company, Quadrex, in B-REAL’s facility. B-REAL ceased operations because of the opposition to its plant and the public outcry over health concerns. Quadrex was a waste management company based out of Florida, and the acquisition of B-REAL's facility depended upon the outcome of the ordinance hearing. Quadrex official Charlie Scheer asserted that the company was interested in the acquisition, but that “if changes in a solid waste disposal ordinance aren’t made, it 'would make it difficult"' for the company to make the purchase. ${ }^{182}$ The 245 petitioners against the ordinance had grown even more concerned about the fate of B-REAL because they quickly discovered that Quadrex’s facilities in Florida dealt with low-level nuclear waste disposal in addition to ethylene glycol recycling, which is what they planned to do with the BREAL plant. ${ }^{183}$ But with the ordinance revised, Quadrex proceeded with the purchase in January 1992. $^{184}$

The ordinance, however, was rolled back by a court injunction, and the Floyd Environmental Action Team continued throughout 1992 to push for new ordinances that could severely limit the types of activities in which industries could engage. ${ }^{185}$ Letters to the editor of The Floyd Press flooded in through the spring of 1992 as word spread about Quadrex’s operation

\footnotetext{
${ }^{181}$ David Kaluszka D.C., “Like Thieves,” Floyd Press, December 12, 1991.

${ }^{182}$ Wanda Combs, “Florida company expresses interest in B-REAL plant,” Floyd Press, December 12, 1991.

183 Roger Mannon, “Overflow crowd attends ordinance hearing; board approves changes,” Floyd Press, December 19, 1991.

184 “Quadrex buys B-REAL plant,” Floyd Press, January 16, 1992.

${ }^{185}$ Roger Mannon, “FEAT urges protection with strong ordinance,” Floyd Press, February 20, 1992.
} 
in Oak Ridge, Tennessee. One person noted that it had been cited multiple years for its failure to properly seal and dispose of radioactive waste from the nuclear facility. ${ }^{186}$ The Floyd Environmental Action Team's fear was that “the county's waste ordinances leave big loopholes by exempting companies which obtain state and federal permits." ${ }^{\text {187 }}$ The board held a public meeting again in late July to discuss revisions that would result in a fourth draft. By September the board had drafted a sixth version, and there was mention of a companion ordinance maintaining that companies "dealing with hazardous waste must make yearly reports to the county.” The Floyd Environmental Action Team again cited several shortcomings: the limited requirements for insurance to guard against spills and other calamities, no specific language against hazardous nuclear waste, vague rules on long-term waste storage, and no requirement for an environmental impact statement, among other things. ${ }^{188}$ Finally, in November of 1992, the Board adopted an ordinance on waste management. "After a year, 10 drafts, two public hearings, a lawsuit and thousands of dollars in legal expenses," reported Roger Mannon, "Floyd County has an amended Solid Waste Ordinance.” The Floyd Environmental Action Team’s major accomplishment included banning operations that would engage in any type of production or recycling of hazardous or radioactive materials. Quadrex never began operations in the county, and in 1995 the company declared bankruptcy and auctioned off the equipment that had once belonged to B-REAL. ${ }^{189}$

\footnotetext{
${ }^{186}$ Fred C. Jones III, “Will They Show the Same Sense of Urgency?” Floyd Press, 5/7/1992.

${ }^{187}$ Roger Mannon, “Quadrex pledges no nukes in Floyd,” Floyd Press, 5/21/1992.

${ }^{188}$ Roger Mannon, "Sixth version of ordinance ready for hearing," Floyd Press, August 20, 1992; Roger Mannon, “Ordinance backers want prohibitions, protection,” Floyd Press, September 24, 1992; Isa Graefe, "Eerie Impression,” Floyd Press, October 8, 1992.

${ }^{189}$ For the Floyd County Solid Waste Ordinance, see "Chapter 42: Solid Waste," under "Floyd County, Virginia ordinances,” http://library1.municode.com/default-now/home.htm?infobase=13477\&doc action=whatsnew ; "Moments: reflections on a year to remember," Floyd Press, January 7, 1993; Cathryn McCue, "Chemical Recycler out of Business; Floyd Company Files for Bankruptcy," The Roanoke Times, June 16, 1995. The ordinance was adopted, but issues related to garbage management dragged on. In 1993, the county revisited the idea of joining the regional waste disposal network and shipping its garbage to other rural areas.
} 
The B-REAL controversy strained relationships in the county both within the alternative sub-community and the broader community. Both natives and newcomers were involved, although the latter certainly played a larger role in leading the movement against the chemical operation and protecting the county's groundwater in general. They were the dominant force in shaping the nature of discourse regarding the county’s environmental quality, and preserving a specific vision of quality of life, during the late 1980s and through the 1990s. Although it is difficult to determine, they may have raised the level of awareness about water quality among the general population. County planner Lydeana Martin believed that they did to some degree, but she added that a severe drought between 1998 and 2002 that prompted wells to go dry in some developments outside of the county seat may have done as much motivate people to act to protect that resource. $^{190}$

While several people openly supported Staengl, it is clear that friendships deteriorated between some of the alter-natives and natives involved with the conflict. One person echoed others' concerns about B-REAL and NovaChem and made it clear that he or she "must set aside my relationships to the personalities involved in the plant and deal directly with the questions this sale brings up.” Indian Valley native Pete Castelli hinted at the division as well when he claimed, "Realize in a democracy debate is okay. We can be friends and disagree. Not speaking out when you feel strongly about an issue is a bigger tragedy. The easiest thing to do is nothing. But these problems will not go away.” And Ed Broderick reflected, “It is easy to tell yourself that someone you know will do the right thing. Unfortunately,” he added, “reality demands more attention to insure this. Personalities can come and go, but wrong decisions can haunt us for decades."191

\footnotetext{
${ }^{190}$ Lydeana Martin, interview by author, Floyd, Virginia, July 25, 2012.

${ }^{191}$ Pete Castelli, “Don’t Deserve to be Dumped On”; Ed Broderick, “Can Haunt Us,” Floyd Press, March 7, 1991.
} 
Reflecting on the controversy, Kamala Bauer believes that her position against the chemical recycling was ultimately correct. But she acknowledged that friendships were lost in the conflict. "Luke, who was somebody I truly—I still do-I really respect the guy. Amazing. Very brilliant.” But “I don’t think he’s ever forgiven me,” she added. “So it was really hard. But I still think I did the right thing. I'm so glad it's not here. And the thing is, he really cares. He's . .. a careful person. He's a well-meaning, honorable person with integrity. It’s just different viewpoints of the same situation. It's kind of interesting. I see why wars start. And how maybe we can prevent them. So that whole process was very educational. Sad, but educational.”192

\section{Conclusion:}

Although the controversy in Floyd County resulted in broken bonds between friends and a divided alternative sub-community, native/newcomer tension never reached the point of open hostility like it did in Lincoln. While both counties struggled to navigate the era’s loosened regulatory atmosphere and economic upheavals, particularly through the late 1980s, Lincoln County's environmental contest was far worse. People were desperate for employment, so much so that they nearly allowed corrupt coal operators to open strip mines near the county seat. In addition, local elites like Jennings Midkiff who were oriented toward resource extraction fiercely defended their power and authority in the community. They became particularly hostile when grassroots groups like Home Place challenged their power. The county's political landscape will be explored at length in Chapter Six. For now, it is important to understand that the processes of “deindustrialization, economic contraction, and forced migration" may have contributed to the "xenophobic creation of that which is foreign" in Lincoln County and other locations suffering

\footnotetext{
${ }^{192}$ Bauer interview.
} 
from similar problems. ${ }^{193}$ Both counties suffered economically from lack of industry and saw industry, particularly textiles, come and go, leaving their populations having to commute for work or depend on government jobs. Not surprisingly, then, tension emerged over the issue of job creation during the environmental debates, and native / newcomer distinctions sometimes emerged in the public discourse. Lincoln County's economic situation was perhaps more dire, so tension there was elevated compared to Floyd.

Another issue that may have exacerbated native/newcomer tension was that of cultural heritage. Kathleen Brennan and Christopher Cooper, who examine natives’ and newcomers’ value differences in western North Carolina, contend that the closer in-migrants' values are to those of the host population, the smoother integration may be. If vast differences exist, the inmigrants may move away, or, conversely, begin to "actively support environmental, developmental, and other community changes” that will help them to acclimate to their new communities. The problem is that locals "may perceive these changes as threatening to the cultural heritage of the region." ${ }^{194}$ Brennan and Cooper point to notions of heritage as being an important defining factor for community relations. Many alter-natives appreciated and respected at least some aspects of regional heritage, particularly as they related to agricultural and forestry traditions. But in both the Floyd and Lincoln County environmental debates, community tensions were exacerbated when alter-natives attempted to inject foreign values into the public dialog. Some locals perceived those values as threatening. In Floyd this occurred when Warren Kimmel proposed the hunting ban during the peak of the chemical recycling debate, while in Lincoln it happened when former marijuana lobbyist Jeremiah Greenberg voiced his support for Home Place.

\footnotetext{
${ }^{193}$ Barbara Ellen Smith, “Appalachian Identity: A Roundtable Discussion,” Appalachian Journal, Fall 2010, 57.

${ }^{194}$ Brennan and Cooper, 282.
} 
Especially intriguing is Brennan's and Cooper’s contention that the longer the inmigrants' remain in their adopted communities, the more their values resemble those of the natives, and the more they act to preserve the local cultural heritage. What they found to be true in western North Carolina seems to have occurred in Floyd and Lincoln counties as well. During environmental and developmental debates, alter-natives commonly referred to their own desire to preserve the rural characteristics of the communities that were in place upon their arrival. ${ }^{195}$ Even when locals irritated by alter-natives’ participation targeted them as “outsiders,” the inmigrants countered by identifying the people promoting industrial development as being the true foreigners and the true threats to the local culture and ways of life. ${ }^{196}$ Still, in spite of community divisions, new relationships were forged between newcomers and like-minded natives who were energized by the in-migrants’ passionate leadership in environmental causes. The campaigns against surface mining and chemical recycling, it is important to remember, likely would not have been successful without the leadership and involvement of natives like Pete Castelli, Jack Spadaro, Thursy Baker, and Julian Martin. These individuals helped to undermine locals’ contentions that environmental leaders were all “outsiders” who injected foreign values and visions into their communities. Recent studies have

\footnotetext{
${ }^{195}$ Brennan and Cooper, 282. Other more amenity-driven and entrepreneurial alter-natives sought to make some changes to the economy but still couched their development drives in terms of preserving the rural character of the community. This will be discussed in the following chapter. Note too that the "gangplank" theory mentioned above, while related specifically to environment in that context, also applies to developmental issues more broadly.

${ }^{196}$ Brennan and Cooper, 292. And although this study does not offer quantitative data related to how different generations of alter-natives felt about protecting the area's cultural heritage, there is some anecdotal evidence from Floyd that certain individuals belonging to the older generation of in-migrants - the people who had been there the longest - had rather ambivalent feelings about the accelerated pace of change in the 1990s. For example, during many of the developmental debates that took place at the same time as the Floyd Environmental Action Team's campaign against B-REAL and FAEC, a few people drew distinctions between the newer entrepreneurial alternatives who arrived in the 1980s and 90s to capitalize on the town's growing hip ethos and older alter-natives who wanted to preserve the county as it had been when they arrived. (Although the discussion of environmental quality below cannot be divorced from discussions about economic initiatives, the bulk of analysis regarding development will be saved for Chapter 6). This dynamic supports the scholars' discovery that western North Carolina in-migrants "likely begin to view themselves as in-group members over time ... which understandably would lead to a heightened sense of threat related to in-migration and development.”
} 
shown, after all, the presence of an indigenous Appalachian form of environmentalism that stems from the region's long tradition of using the commons, close connection to the land, and concern for individual property rights. ${ }^{197}$ Finally, the campaigns did, as some scholars suggest, help to build support in these two Appalachian communities for environmental protections. "New migrants," they observed in 1999, "seem to be reinvigorating or at least strengthening environmental values in rural areas of" southern Appalachia. ${ }^{198}$ Both case studies suggest that while efforts started small, support gradually built for local environmental protections.

Writing in 1989, John Salstrom's brother Paul, who had at one time held property on the very ridge that Black Gold and Mountain Black Diamond intended to mine, conveyed to Appalachian Journal readers the drama occurring in Lincoln County. Using Julian Martin’s Department of Energy testimony as a launching point for his analysis, he quoted the man's poignant statement regarding surface mining, "Surely to God there must be another option.” Martin, like the members of Home Place, realized that they could not fight an industry so heavily entrenched in southern West Virginia without offering economic alternatives for the county. Home Place charged Paul Salstrom, who had a newly minted Ph.D. in economic history, with the task of exploring those options. Paul admitted that his first thought was to encourage home

\footnotetext{
${ }^{197}$ Kathryn Newfont, Blue Ridge Commons: Environmental Activism and Forest History in Western North Carolina (Athens: University of Georgia Press, 2012), 10-13; Montrie, 4; Robert Emmett Jones, J. Mark Fly, and H. Ken Cordell, "How Green is My Valley? Tracking Rural and Urban Environmentalism in the Southern Appalachian Ecoregion,” Rural Sociology 64, no. 3 (1999): 494. Kathryn Newfont argues that in order to understand the complexities of American environmentalism, we need to attend more closely to rural populations and how they perceived their local landscapes and acted to preserve them. She identifies "commons environmentalism" in the mountains of western North Carolina that prompted natives there to act against any enclosure movements or restrictive policies by elites and, later, the federal government that might have prevented them from reaping the economic and recreational benefits of mountain forests. Chad Montrie's exploration of anti-strip mining activism in the coalfields points to another indigenous movement that sought to protect private property and water from the devastation of surface mining. Many of the in-migrants who emerged as leaders in the anti-strip mining movements of the 1960s and 70s joined indigenous movements' grassroots campaigns.

198 Jones, Fly, and Cordell, "How Green is My Valley?” 495.
} 
grown development of forestry products. ${ }^{199}$ But given the abysmally low "ratio of bank loans to bank deposits" in Lincoln County, such businesses were unlikely to flourish. (Lincoln, he added, actually had the lowest ratio in the state, while the state of West Virginia likewise had the lowest ratio in the country. This qualified Lincoln County for the "booby prize as far as economic enterprise is concerned." $)^{200}$

Salstrom anticipated that Appalachian Journal readers, activists and scholars typically critical of capitalist enterprises, would likely feel unsettled by any proposal that might further entrench exploitative economic systems in the mountains. They believed at the time that economic enterprise had once undermined traditional agrarian communities. But "economic enterprise was once just as 'traditional’ as anything else about Appalachia,” asserted Salstrom. His recommendation: to build Lincoln County's tourism industry by partnering with the National Park Service. More specifically, Salstrom envisioned using the region's labor history to draw tourists to the area, although he recognized that tourism came with its own set of challenges. "Even if tourism and a retiree influx are viable ways to attract money, might they not prove deadly for Appalachia’s culture—an embrace that kills?” he asked. “Wouldn’t an influx of tourists and retirees in fact breed a living death, a shopping-center wasteland in the hills?” Salstrom dismissed such questioning as "overly pessimistic.”201 But similar questions about using tourism to counter industrial development echoed throughout Appalachia during environmental debates. Alter-natives looked to the region's heritage to market their new enterprises to potential tourists, and tourism became one of the few agreeable alternatives to

\footnotetext{
${ }^{199}$ Salstrom's family had been in the woodcarving business in Illinois. There were several woodshops in the county, he noted, two from alter-natives and two from natives.

${ }^{200}$ Paul Salstrom, “Cash is a Four-Letter Word,” Appalachian Journal (Spring 1989): 242-255; Julian Martin, West Virginia Strip Mining, Public Hearing held by the West Virginia Department of Energy, June 28, 1988, Special Collections Department, Marshall University.

${ }^{201}$ Salstrom, “Cash is a Four-Letter Word,” 245-246, 250-255.
} 
industrial development. As we shall see in Chapter Six, alter-natives in both communities put significant time and energy forth to try to cultivate businesses that blended elements of regional heritage with environmental sensibilities and countercultural values. Those in Floyd joined enterprising natives to create a hybrid downtown that represented an odd mixture of local and alter-native interests. Lincoln alter-natives had less success in developing their local tourist industry, although not for lack of trying. 


\section{Chapter Six}

\section{“Economic Growth or Economic Justice?” Economic Development in Floyd and Lincoln Counties}

The Harvest Moon had its roots in the Floyd Mill Co-op, a local buy-in club similar to the dozens of other food cooperatives that opened across the Appalachian Mountains during the 1970s. The Mill Co-op, named for the old Epperly Grist Mill that housed it, started in October of 1976 and soon emerged as an important social hub for Floyd's alternative subculture. Because the co-op struggled financially through the early 1980s and suffered from a lack of volunteers who devoted their energy to other community organizations, a woman named Margie Michau [Ryan] purchased the business in $1983 .{ }^{1}$ Michau had managed the co-op for several years before her acquisition, and under her direction she sought to expand its presence as a "community center" and outlet for local craftspeople, farmers, and artists to sell their products and to keep "money in the community." Upon purchasing the co-op, she moved the store’s location to downtown Floyd and changed the name to Harvest Moon.

Like many Main Street districts across America, downtown Floyd's role as the community’s commercial and social hub had diminished in the postwar era. As highways improved, people began traveling the twenty to forty-some-odd miles to Christiansburg, Blacksburg, or Roanoke to do their shopping rather than spending money in the downtown district. Stores came and went, the downtown deteriorated, and by 2000, only one shop, the

\footnotetext{
${ }^{1}$ Dawn Baumgartner, "Harvest Moon Rises in New Location,” The Roanoke Times, February 23, 2003; Katherine Chantal, interview by author, Floyd, Virginia, August 3, 2011. Chantal recalls Michau's date of purchase as having been in 1982, although the Roanoke Times reports it as having been in 1983. She also claimed that the same volunteers who would have otherwise supported the co-op became more involved with the founding of an alternative school.

${ }^{2}$ Chris Reilly, “Co-op Offers Alternative Foods,” Floyd Press, May 1, 1980.
} 
Farmers' Supply Corps, which first opened its doors in 1932, survived. Floyd business owners grew desperate to generate income and keep their stores open. In November of 1977, the Bank of Floyd sponsored an ad imploring county residents to "Try Floyd County First." "Hometown shopping," it explained, "keeps local dollars in Floyd County, and thus helps to keep our economy healthy. It creates more jobs, it improves the standard of living, and it helps make possible a wider selection of merchandise in our stores.”3 Their arguments for bolstering local business were remarkably similar to those of newcomers like Michau, who supported the cultivation of local businesses to keep money circulating within the community.

Shared values, however, did not mean that all parties interested in Floyd's revitalization agreed upon how that process should unfold. While a survey taken in the 2005 suggested that both natives and newcomers felt protective of the county's landscape, natural resources, and small-town feel, it exposed differing opinions regarding whether the community should develop at all and, if so, the types of businesses that the community should allow for services and job creation. Throughout the late 1980s and 1990s, debates about development reflected a multitude of visions about the meaning and purpose of "community." Natives might have expressed desires for modern amenities and jobs that might have brought some community change, but their requests for those things were often shaped by concerns about the deterioration of Floyd's social fabric as their own sons and daughters had to seek work elsewhere. They longed for the social structures and familiarity—as tinged with nostalgia as the vision might have been—that preceded the back-to-the-land movement. Newcomers continued to seek Gemeinschaft that they felt had been lost in the postwar era, and that desire often informed their advocacy for small,

\footnotetext{
3 “Bank encourages residents to shop Floyd County 'First,'” Floyd Press, November 24, 1977.
} 
decentralized enterprises. So while some of the fundamental desires might have resembled each other, the ways each party sought to fulfill those visions could be dramatically different.

As with the environmental contests, the alter-natives maintained a strong, although not unified, voice in community discussions about economic development. The ones who favored development—many did not—advocated decentralized alternatives to large-scale industry or corporate enterprises. Typically they promoted small-scale agriculture, the development of local businesses for a tourist economy, and locally-owned craft production and/or manufacturing. Reflective of the broader social reformist bent of the back-to-the-land movement and modern concerns about global economic collapse, some also introduced a local currency to formalize the well-entrenched underground economy. Natives supported some of these efforts, particularly related to the cultivation of heritage tourism, and at times there was remarkable cooperation between the two groups. But differing opinions about other types of development, particularly related to service industries like chain restaurants and grocery stores, periodically exacerbated native/newcomer tension. Simple debates over what types of development to allow into Floyd led to broader arguments about rights, citizenship, and the meaning of community.

Lincoln County alter-natives likewise became involved with economic development initiatives. At the peak of the back-to-the-land migration the county hosted a significant number of artists, craftspeople, and farmers who sought to generate income in ways similar to Floydian alter-natives. Many realized they would have to seek revenue outside of the county and hoped that one day there would be opportunities to have a home market for their products. During and after the intense community debates on surface mining and resource extraction, alter-natives presented their visions of economic development based on timbering, crafts, and agricultural products. But unlike in Floyd, there was limited interest among local power elites in shifting the 
local economy away from fossil fuel extraction. In fact, rampant political corruption in the county hampered efforts to develop the local economy and, as this chapter argues, contributed to a renewed outmigration of alter-natives who might have otherwise stayed and devoted human capital to local initiatives, including economic development.

Newcomers' success with their economic development initiatives depended on a variety of factors, including location, regional and state support for economic development, and local politicians' and business elites' willingness to share economic and political authority. By exploring Floyd and Lincoln County alter-natives' efforts to reshape their local economies, it becomes quite clear that the more open community leaders were to different visions of development, the more successful they were in finding solutions to local economic problems. There were remarkable similarities between Floyd and Lincoln counties in terms of their economic landscapes at the beginning of the 1970s and even in the solutions that alter-natives and natives proposed for regional economic problems, but the communities had diverged dramatically by the 1990s as Floyd County began to "brand" itself as a unique and eclectic cultural destination and Lincoln continued to suffer under the weight of domineering local politicians who were not eager to relinquish political power. Further, debates about economic development also reflected the values, hopes, and desires of in-migrants and natives. Idealized concepts of community surfaced as different generations of Floydian alter-natives advocated for their visions of community and development, Lincoln County alter-natives voiced their desire to preserve the rugged topography of their county for future generations, and natives in both locations hoped for business opportunities that could keep their kin local and bring their communities into the economic mainstream. 
The Underground Economy

The exploration of economic development begins with consideration of the underground economy and the role it played in regional economic development and shaping community relations. In both communities, alter-natives joined natives’ existing barter networks, building farms and homesteads off of traded labor and supplies. Some also engaged in illegal economic activities like marijuana production in order to support their dreams of self-sufficiency. Such activities reflected both the counterculture's criticism of the U.S. government and its propensity for drug use, as well as concerns about the environment and distaste for rampant materialism. Although marijuana production was common, barter far surpassed it as one of the defining features of the back-to-the-land lifestyle in Appalachia and elsewhere. And significantly for Appalachian alter-natives, such activities fit within long-standing indigenous traditions of trade and illicit distilling that stemmed from the region's cash-poor economy. ${ }^{4}$

\section{Barter Networks in Floyd and Lincoln Counties}

Bartering has a long history in Appalachia that stems back to its preindustrial era.

Preindustrial Appalachian residents relied upon what Paul Salstrom has identified as “subsistence-barter-and-borrow” networks. They may have been entrepreneurial, he contends, producing cattle and other agricultural or forest items for the open market, but the transactions were typically conducted without cash. People traded goods or labor, and elements of this underground system remained in place well after Appalachia industrialized. The introduction of outside capital and, later, New Deal programs introduced limited amounts of cash into

\footnotetext{
${ }^{4}$ Editor, “Report from Them That's Doin': Bartering,” Mother Earth News, http://www.motherearthnews.com/nature-community/bartering-zmaz76zhar.aspx (accessed February 6, 2013). As evidence of the widespread reliance on barter among homesteaders and communitarians, Mother Earth News began publishing a series in 1976 called “Successful Swaps” which showcased peoples' trades.
} 
Appalachia—New Dealers promoted the idea of welfare payments in part so that rural Americans could help bolster the consumer economy—but this "tended to undermine local subsistence-barter-and-borrow networks by making the possession of money a precondition for an increased proportion of local transactions." ${ }^{5}$ Still, the practice persisted and may have actually increased during the last decades of the $20^{\text {th }}$ century. Along with other forms of underground economic activities like illicit drug sales, some studies suggest that America’s shadow economy actually grew because of disaffection with the federal government by people on both the right and the left (including the counterculture) and high income tax rates and government regulation. “Economic hardship,” writes one scholar, along with “a desire for illegal profits” may have bolstered the underground economy as well as the barter networks that were already in place. ${ }^{6}$

In-migrants who came with little money often supported their communes and homesteads by bartering with locals and with each other. They obtained tools, seeds, supplies, healthcare, and sometimes even land and cars, by trading in-kind with locals or other alter-natives. Although Floyd is technically situated in "older Appalachia," elements of the "subsistence-barter-andborrow” networks remained because its agricultural-based economy and limited manufacturing base never flourished enough to bring prosperity in the post-war era. One news account of

\footnotetext{
${ }^{5}$ Paul Salstrom, Appalachia's Path to Dependency: Rethinking a Region's Economic History, 1730-1940 (Lexington: University Press of Kentucky, 1994), viii, xiii-xxxvi. Industrialization introduced cash to many parts of the region, but levels still often remained far lower than other industrialized areas of the country. However, there are subregional differences that account for the different ways in which Appalachia's economy developed through the late $19^{\text {th }}$ and $20^{\text {th }}$ century. Areas like "older Appalachia," which included the Valley of Virginia and Floyd County, navigated economic changes more successfully because excess population still had opportunities to resettle in less densely populated areas before the closing of the frontier. Newer Appalachia, however, which includes the Appalachian Plateau and Lincoln County, was the most rugged and last to be settled, so it had no chance to achieve a similar "demographic equilibrium" by the time of industrialization. The surplus population became wage laborers in the region's timber and coal camps, and people accepted extremely low wages because they continued to supplement incomes with subsistence farming. Salstrom argues that subsistence farming actually subsidized resource extraction, because if laborer/farmers had been completely dependent upon industry for their survival, many companies would not have been able to turn a profit. As a result, that section of Appalachia in particular remained low-cash until the New Deal.

${ }^{6}$ Eric Schlosser, Reefer Madness: Sex, Drugs, and Cheap Labor in the American Black Market (Boston: Houghton Mifflin Company, 2003), 5-6.
} 
bartering in Floyd reported that a man who had visited the Harvest Moon "worked for 15 minutes on the grounds, and claimed a few croissants as payment the next day.” Floyd also had a medical clinic that was operated via barter. And the owner of Oddfella’s Cantina reportedly purchased her business by "offering the seller $\$ 2,000$ worth of food and drink at their place ... Payment in full., ${ }^{7}$ Even luxury items were obtained through barter: A'Court Bason of Floyd traded for musical instruments he could not build himself. ${ }^{8}$

Barter networks were also prevalent in Lincoln County. Trade was so common between neighbors and in-migrants, in fact, that Jan Salstrom described Lincoln County plainly as “a barter economy." She and others relied on "trading work, trading things that you could make for each other." ${ }^{9}$ Her brother-in-law Paul likewise recalled the presence of indigenous trade networks in Lincoln County and in 1989 confessed that his ability to survive there depended upon picking apples for wages elsewhere each fall and "farming a little, bartering a lot, [and] exchanging work days” with other residents. ${ }^{10} \mathrm{He}$ and others attended regional flea markets where people traded goods in addition to buying and selling: "the big flea market was up in Putnam County, just north of Lincoln County ... So people would go up there and see what they could get, or what they could get rid of. But just around the neighborhood you had to borrow things because you couldn’t afford to buy them."11

For many alter-natives, bartering was more than just a survival tactic. It also served important political and social functions, reflecting their desire to buy out of the modern consumer economy and capitalist system. Barter, like the back-to-the-land lifestyle more

\footnotetext{
${ }^{7}$ Calvin Woodward, "Roads less traveled: Bartering is old way to get what you want," USA Today, July 5, 2005, http://usatoday30.usatoday.com/travel/destinations/2005-07-05-cash-free-floyd_x.htm (accessed February 5, 2013).

${ }^{8}$ A'Court Bason, interview by author, Floyd, Virginia, August 1, 2011.

${ }^{9}$ Jan Salstrom, interview by author, Morgantown, WV, November 20, 2008.

${ }^{10}$ Paul Salstrom, “Cash is a Four Letter Word,” Appalachian Journal (Spring 1989): 244.

${ }^{11}$ Paul Salstrom, interview by author, Morgantown, WV, March 6, 2008.
} 
generally, can be understood as another form of dissent, reflecting the social reformist impulse that undergirded twentieth century back-to-the-land movements. Movement luminaries like Helen and Scott Nearing and Wendell Berry infused economic critiques with their decisions to homestead, and they provided working models for other homesteaders seeking economic alternatives. The Nearings, for example, were early models for the 1970s generation of homesteaders; they offered critiques of mass consumption, American imperialism, and the "price-profit economy" as inherently corrupt and labored to insulate themselves from market fluctuations by becoming "producer-consumers." Roughly three-fourths of their income came from what they produced themselves, and they created detailed budgets to ensure that they never spent beyond their means. The Nearings "bartered part of" their "crop for the surpluses of other primary producers of fruit, nuts, [and] oils" so that they could bypass "the commodity market with its heavy overhead costs.” Demonstrating their extreme asceticism and rigidity in spending, they "never borrowed," thereby freeing themselves "from interest slavery ... one of the heaviest economic burdens of many primary producers.”12 Like the Nearings, Karl Hess had grown so critical of the military industrial complex that he quit paying income taxes after moving to West Virginia. He eked out "a subsistence living by bartering his welding” and his wife’s writing for the things they could not produce. ${ }^{13}$ Wendell Berry too offered his own assessment of neighborly reciprocity, asserting that it held social value far more significant than any monetary value that might be attached to conventional work. ${ }^{14}$

\footnotetext{
${ }^{12}$ Scott Nearing, The Making of a Radical: A Political Autobiography (New York: Harper Colophon Books, 1972), 213-214.

${ }^{13}$ Karl Hess, “The Plowboy Interview: Karl Hess,” Mother Earth News, Jan./Feb. 1976, http://www.motherearthnews.com/Green-Homes/1976-01-01/The-Plowboy-Interview-Karl-Hess.aspx (accessed Apr. 14, 2008).

${ }^{14}$ Wendell Berry, “The Plowboy Interview,” Mother Earth News, March/April 1973, http://www.motherearthnews.com/nature-community/wendell-berry.aspx (accessed February 6, 2013).
} 
Many alter-natives similarly grounded their decisions to barter in their disillusionment with mass consumption, the military industrial complex, and a debt-ridden society, so in some locations, bartering networks formalized as in-migrants attempted to find ways to use trade to bolster the local economy. In Floyd, bartering evolved from simple neighborly exchanges to an alternative currency that was implemented in the 2000s. The process began with the development of "Barter Fairs" (later spelled Faires) in the 1980s, which served both social and economic functions. An alter-native-backed organization called the Educational Resource Cooperative (ERC)—a "legal umbrella" that supported the creation and development of the alternative community's school, Blue Mountain, and an organization that loosely bound together the many facets of the Floyd counterculture—organized the Barter Faires and used them as fundraisers for school buildings and other projects. ${ }^{15}$ In the late summer of 1984, the ERC proposed having a yard sale to support the school. But by September the decision had been made to change it to an “Autumn Bazaar and Barter Fair” that offered "quality used items . . . homemade goods, handiwork, preserves, and craft items” and hosted “children's activities, face painting and possibly a movie Saturday night.”16 "Now is your chance to trade-anything or skill with someone else in the community," read the ERC newsletter in October. "Or write what you want and what you have [to] offer clearly on a paper that can be posted on the Barter Bulletin Board ... remember, anything from extra garden produce to massage, whatever might be needed by someone is fine." ${ }^{17}$

Through the years the Barter Faires grew in size and sophistication, and they, along with other ERC activities, helped to shape the identity and cohesion of the alternative community. In

\footnotetext{
${ }^{15}$ Kathryn Chantal, “Thoughts about E.R.C.,” The Educational Resource Cooperative Newsletter, September 1985. 16 "Yard Sale Changed To...” The Educational Resource Cooperative Newsletter, September 1984.

17 “Autumn Bazaar and Barter Fair Oct. 13-14,” The Educational Resource Cooperative Newsletter, October 1984.
} 
1987 Kathryn DeLauney waxed eloquent on her belief that the events had evolved into a "community forum ... a spacious common ground where" members of the alternative community could "share what we make, what we think, and what we hope for." ${ }^{\text {18 }}$ She also believed that they offered a solution to social anomie prompted by the rise of consumer culture and corrupting technological advancements during the $20^{\text {th }}$ century. The fairs, and the act of celebrating the fall season, could ameliorate the "residual rigidness" that "scientific materialism and technological morality" imposed upon society. "We can weave into the pattern of our blossoming culture,” she continued, "because the Barter Faire, as all our group celebrations create by our co-operativeness the living art which defines human culture. By living harmoniously; integrating the practical with the visionary and striving toward wholeness we make the forms of our culture: so the Barter Faire is a form maker-a vessel for our creative spirit."19

Bartering continued to formalize as alter-natives explored ever more complex trade systems, including a Local Exchange Trading System, or “LETS,” which a Canadian named Michael Linton first developed in British Columbia in the 1980s. LETS operated by keeping track of bartered goods or services through a computerized database and the use of an alternative currency called "green dollars." The database cataloged debits and credits so that individuals could make exchanges with anyone in the community rather than having to exchange with the person from whom they received something. ${ }^{20}$ Will Bason introduced the idea to Floydian alternatives, and it was bandied about in the ERC newsletter and at the Barter Faires in 1987 and

\footnotetext{
${ }^{18}$ Kathryn DeLauney, "Barter Faire,” The Educational Resource Cooperative Newsletter, October 1987.

${ }^{19}$ Kathryn DeLauney, "Barter Faire," Educational Resource Cooperative Newsletter, October 1987; "1990 Barter Faire," A Museletter: The CERC Newsletter, August 1990. In 1990, the newsletter announced that the Barter Faires would start being advertised on the Virginia Craft Council's website, indicating the growing awareness of Floyd as a center for craft production.

20 "Barter System Generates Wealth,” The Globe and Mail, August 23, 1984.
} 
1988. ${ }^{21}$ By 1990, it was up and running. People could join by sending money ("imperial credits" or "an actual check or money order symbolizing real pictures of dead presidents which in turn symbolize the real or imagined wealth of this great nation”) to have their names listed in a human resource directory. The directory provided people with the names and skills of other local residents to facilitate the exchange of goods and services. Ed Gralla described it as "spectacular," for it gave people the opportunity to list their "knowledges ... expertise," and "desire to learn different things." 22

In the recessionary years of the early 1990s several communities across America and within the greater Appalachian region sought to formalize their barter economies by creating local monetary systems. Alternative currencies were nothing new; Ralph Borsodi and other social critics throughout the $20^{\text {th }}$ century had created alternative economic systems to reduce dependency on centralized money. As Heathcote resident Robert Mernick explained of the “Constant,” which Borsodi and Robert Swann co-developed in the early 1970s, the idea was to develop “an alternative to the American dollar” that would be backed by stable commodities such as “cotton, corn, wheat, [and] oil.” Even amidst inflation, Constants would "retain the buying power they had when received." ${ }^{23}$ Before that, many small communities had returned to

\footnotetext{
${ }^{21}$ Greg Arens, "Letter to the ERC Newsletter," The Educational Resource Cooperative newsletter, November 1987; Kamala Bauer, interview by author, Floyd, Virginia, August 1, 2011. At least one Floydian found the British Columbia model to be too cumbersome, so he proposed simplifying the system; he believed they should eliminate the computer and any employees who would be responsible for logging transactions.

${ }^{22}$ Will Bason, "LETS Get It Together," A Museletter: The Community Education and Resource Coalition Newsletter, April 1990; Ed Gralla, interview by author, Floyd, Virginia, August 4, 2011.

${ }^{23}$ Robert Mernick, “Can New-Agers Create New Money?” Green Revolution 11, no. 1 (January 1973); Robert Swann and Susan Witt, "Local Currencies: Catalysts for Sustainable Regional Economies,” New Economics Institute, http://neweconomicsinstitute.org/publications/authors/Swann/Robert/local-currencies-catalystssustainable-regional-economies (accessed December 20, 2012). According to economist Robert Swann, local scrip was prevalent until the Civil War, when the Federal Government began printing national money to assist the war effort. But it was not until 1913 that the Federal Government "centralized the production of money" through the Federal Reserve Act. The Industrial Revolution necessitated the production of a uniform currency since it sparked the movement of products and people on an unprecedented scale. But the downside of this centralization was that
} 
local scrip to mitigate the ill effects of the Great Depression. And many Appalachian coal companies notoriously paid miners in scrip to limit miners’ mobility and to improve bottom lines. As Tennessee Ernie Ford sang, many miners labored to become "another day older and deeper in debt" to the point that they, too, owed all but their souls "to the company store."24

More recent, and more ethical, regional currencies began in places like Ithaca, New York, in the 1990s. The Ithaca HOURS system became a model for other labor-based scrip systems that emerged in Mars Hill, North Carolina, and Floyd. Ithaca's HOUR was based on average local wages, which were ten dollars per hour, and the HOUR notes came in "five denominations.” Most Ithaca businesses accepted HOURS, including banks, landlords, doctors, and other services. Like barter advocates in Floyd, Ithaca HOUR supporters hoped that the system would "replace dependence on imports." ${ }^{25}$ In Mars Hill, the money formalized a barter system that had long been in place. The currency's founders started a directory called the Barter Partners Network that listed several hundred participants, and they eventually issued currency in “denominations of an hour, half-hour and quarter hour.” “It costs \$12 to join,” explained a journalist, "and each member gets two free hours of Mountain Money and a list of hundreds of people who want to trade, from accounting to clairvoyant readings to wilderness-excursion planning." 26

Plans for the scrip system in Floyd began in 2000. The reasons for implementing the currency were based on both practicality and economic and environmental concerns. The

money shifted away from local or regional systems to large corporate banks. This arrangement made money more fluid but it also left rural residents vulnerable to fluctuations in the market and corrupt banking practices.

${ }^{24}$ Tennessee Ernie Ford, “Sixteen Tons,” Lyrics Freak, http://www.lyricsfreak.com/f/ford+tennesee+ernie/sixteen+tons_20632824.html (accessed February 6, 2013).

${ }^{25}$ Paul Glover, "Creating Community Economics with Local Currency,” Ithaca HOURS, http://www.paulglover.org/hourintro.html (accessed January 7, 2013).

${ }^{26}$ Ricki Morrell, “Trade You My Alienation for Some of Your Herb,” Appalachian Journal 24, no.3 (Spring 1997), 250-251. 
initiators believed barter alone "always limits our exchanges by its simple one to one ratio of participants.” They wanted to be able to enter into more complex barter arrangements.

Organizers also believed in alternative currency for its ability to circumvent exploitative corporate business practices by keeping money circulating among locally-owned enterprises: "By choosing to value and circulate local scrip, we again and again create the opportunity for ourselves, our neighbors and our regional community to recapture that value, which in turn stabilizes and increases the general well being of our community—a conscious alternative to giving our federal reserve notes to multinational corporations who have no regard for our wellbeing."27 "Regional currency has proven that ecology and the economy can be friends," asserted the local scrip study group in a press release in early $2000 .^{28}$

Proponents of local bartering used the festivals, the directory, and the local scrip to strengthen community cohesion. They frequently expressed their desire to see the "old and new communities" come together through shared exchanges. In 1987, they reached out to "local youth and church groups" to attend, along with "local singing and music groups and church choirs. ${ }^{29}$ But although bartering had a long history in Appalachia, locals' involvement with alter-natives' formal barter networks was low. In 2000, Rex Bowman of the Richmond Times profiled Floyd's efforts to start a local scrip system. He, like many other non-local journalists who observed the eclectic mixture of people in Floyd, focused on divisions between the countercultural community and the natives. He interviewed several natives who were unsure about the benefits of local money. One business owner remarked, “'I don’t know why they need money to begin with ... They barter for everything already.'” County Prosecutor Gino Williams

\footnotetext{
${ }^{27}$ Scrip Study Group, “Update from the local scrip study group: questions we’ve been addressing,” Museletter, June 2000.

${ }^{28}$ Local Scrip Study Group, “Press Release,” Local Scrip Study Group Papers, March 20, 2000, copies in the author's possession, originally found in Jesse Peterman Memorial Library, Floyd, Virginia.

29 "Barter Faire—a community effort," Floyd Press, October 1, 1987.
} 
believed that “'it would only be used by a small group”” and that “'some places wouldn’t accept it."” And local historian and community elder Marguerite Tise commented, “'I declare, it’s so far out, I can’t imagine that it would work . . . I never heard of such a thing.'”30 But other accounts highlighted the shared interest in barter. Associated Press reporter Calvin Woodward claimed that Floyd's counterculture and local population "had something in common, lack of money. The locals wanted it but didn't have it," he remarked, while "the newcomers with the tie-dyed shirts didn’t care much about the dollar—some despised it—but, like everyone else, they had to pay the bills.” "So together," he concluded, "they took something ancient and made it new."31

Any lingering doubts among locals were not for alter-natives' lack of trying. The first several Barter Faires were not mentioned in the Floyd Press, but press releases for the festivals appeared beginning in the late 1980s. Kathryn DeLauney expressed her desire to see the event bring "old and new communities" together. She believed that the Barter Faire was "a great way to share our prosperity and perpetuate” local "traditions and culture.” And in response to Rex Bowman's cynical examination of the scrip system, Dawn Shiner, one of the scrip system's key organizers, crafted a press release maintaining that "many of us are working toward more cooperative efforts, embracing the diversity with the rural beauty of Floyd.” To overcome reservations, the organizers put together "outreach packets which will serve to educate the general public.” And she extended an invitation to anyone "interested in joining us in our explorations and tasks., ${ }^{32}$

As it turns out, the scrip naysayers were justified in their concerns. Called Floyd Hours, or Floydian Scrip, the money had a short life span. By 2005 the system had fizzled as people

\footnotetext{
${ }^{30}$ Rex Bowman, “Currency Plan Splits Floyd; Group: Local Money Will Boost Economy,” Richmond Times, July 26, 2000.

${ }^{31}$ Calvin Woodward, "Roads less traveled: Bartering is old way to get what you want,” USA Today, July 5, 2005.

${ }^{32}$ Scrip Study Group, "Letter to the Editor,” Local Scrip Study Group Papers, August 6, 2000, copies in the author's possession, originally found in Jesse Peterman Memorial Library, Floyd, Virginia.
} 
realized that exchanging paper currency was just an extra step in a barter system already well entrenched in the local culture. Alter-natives spoke fondly of the system, but many realized with humor that it was somewhat redundant. "It’s like trying to keep track of karma," remarked Blue Mountain Mercantile owner Kalinda Wycoff. ${ }^{33}$ Ed Gralla concluded that it was a "bust." "I wound up having a lot of dollars, a lot invested in it, like the [ethanol] still. I had significant investment in it.” But, he added reflectively, “you don’t need to win on all your investments. Sometimes winning is just doing it, saying that it happened, and still having the money in my desk to remember that it was a project that worked" for a time, "and I shared with people."34

\section{“There's Pot in Them Thar Hills": Marijuana and the Underground Economy}

Along with barter, which can often include traded labor or professional services that go unreported to the IRS, there are dozens of practices that make up America's "shadow economy": counterfeit products, child labor, undocumented workers, tax evasion. Add to that list marijuana production, which became commonplace in the Appalachian region during and after the 1970s for a variety of reasons, including the back-to-the-land movement. In many locations alternatives grew marijuana either for personal use or for sale, and the plant helped to finance farms, purchase equipment, and otherwise support in-migrants’ agrarian lifestyles. ${ }^{35}$ In 1983, for example, Steve Byler pled guilty to the possession of "more than five pounds of hashish ... with

\footnotetext{
${ }^{33}$ Woodward, "Road less traveled."

${ }^{34}$ Gralla interview.

${ }^{35}$ Timothy Miller, The Hippies and American Values (Knoxville: University of Tennessee Press, 1991), 25-30. An alter-native once advised me that if I am to understand the social dynamics that occurred between natives and countercultural newcomers, I must examine the role drugs played in that process. Certain drugs were central to the Vietnam-era's counterculture. Religious scholar Timothy Miller contends that "dope," meaning the classification of psychedelic substances that were regarded for their ability to expand consciousness, was "utterly intrinsic" to the counterculture. Marijuana, along with LSD, mushrooms, and other hallucinogens, was part of the hedonistic hip ethos regarded for its revolutionary and spiritual potentials. People smoked pot because it was fun, because it was against the grain, and because they believed that it could help them to achieve a deeper sense of meaning and purpose.
} 
intent to distribute." He confessed that he had grown marijuana in order to "purchase a 90-acre farm two miles northwest of the town of Floyd."36

At times marijuana was a contentious issue in Appalachian communities following the back-to-the-land migration. Preachers and parents feared its detrimental effects on society, particularly young people, and those fears were stoked by media reports of doped up college kids engaging in free love and communal living and any other variety of unconventional behaviors. What is more surprising is that local responses to marijuana were not always negative. Some residents tolerated it among their neighbors—-part of that "live and let live" attitude that so many alter-natives observed among their neighbors—-while others even incorporated it into their existing underground economic activities. Attitudes toward marijuana in Floyd and Lincoln counties, like other areas of Appalachia where the mythical sons and daughters of pioneers coexisted with the sons and daughters of Aquarius, were complex. As with the dozens of other examples of alter-natives' values, practices, and outlooks that sometimes fit awkwardly, but not impossibly, within existing local patterns, even something as potentially divisive as marijuana found its moments of acceptance. Marijuana, like organic farming, holistic medicine, and music traditions, became another component of the hybridization process that began when back-to-thelanders first moved into Appalachia in the early 1970s.

In August of 1981, a Washington Post headline read, "There’s Pot in Them Thar Hills.” The article exposed an ongoing battle to curb marijuana production in Floyd County, and like so many other reports of community dynamics following the back-to-the-land migration, the contest appeared to have pitted native against newcomer. Sheriff George Branscome was the brains and

\footnotetext{
${ }^{36}$ Charles D. Thompson, Jr. Spirits of Just Men: Mountaineers, Liquor Bosses, and Lawmen in the Moonshine Capital of the World (Urbana: University of Illinois Press, 2011), xviii; "Area farmer pleads guilty to drug possession charge,” Floyd Press, August 18, 1983.
} 
motivation behind an operation to dismantle the county’s booming marijuana industry. Between July and August the sheriff had raided "six marijuana fields," arrested half a dozen people, and confiscated “more than 2,000 plants” worth $\$ 200,000$. Backing the sheriff was a team of five deputies and a group of local citizens who had grown frustrated with ongoing reports of pot production and busts that had appeared in the local newspaper almost weekly during the summer and fall months in previous years. They attributed marijuana's presence to the alter-natives, who they believed had introduced the illicit drug into the community. ${ }^{37}$

Reporter Mike Sager described Branscome as a man with a "face as stern and creased as the thick bark of the Red Oak trees that line the gravel roadways winding through the hills.” His weathered appearance likely came from his pre-public official tenure as a mechanic and the eleven years he had spent outdoors hunting the marijuana stands and moonshine stills that dotted the Blue Ridge. ${ }^{38}$ Floyd had a long-standing reputation for white lightening production that perhaps only paled in comparison to its eastern neighbor, Franklin County, the "moonshine capital of the world.” ${ }^{39}$ That activity, in the minds of the locals interviewed for the article, was tolerable, if not celebrated. Branscome himself admitted to “dipping moonshine from a water bucket between dances” as a youth because "getting drunk was one of the ways a man had his

\footnotetext{
${ }^{37}$ Alfred W. McCoy, “The Stimulus of Prohibition: A Critical History of the Global Narcotics Trade,” in Dangerous Harvest: Drug Plants and the Transformation of Indigenous Landscapes, Michael K. Steinberg, Joseph J. Hobbs, and Kent Mathewson, eds. (New York: Oxford University Press, 2004), 48; Jerome H. Skolnick, "A Critical Look at the National Drug Control Policy," Yale Law and Policy Review 8, no. 1 (1990), 85; Schlosser, 35-36. Sheriff Branscome's raids corresponded with a nationwide increase in marijuana production —and the development of more potent sensimilla that emanated from California — and the beginning of President Reagan's war on drugs. President Nixon's earlier campaign had the dual effect of shutting down the Mexican marijuana trade and escalating, in response, domestic production that reached into Appalachia. Restrictions to imports escalated the price of domestic marijuana, making it extremely profitable to produce. Eric Schlosser believes that the Mexican use of certain pesticides on marijuana crops also helped to facilitate the rise of the American pot industry. He claims that the U.S. Public Health Service issued a warning about paraquat's ill effects on human lung tissue, and this, in turn, increased domestic production.

${ }^{38}$ Mike Sager, “There’s Pot in Them Thar Hills,” Washington Post, August 15, 1981.

${ }^{39}$ For an in-depth examination of the history of moonshining in Franklin County, Virginia, that includes analysis of a major trial that exposed the level to which people depended on moonshine for survival, see Thompson, Jr., Spirits of Just Men.
} 
fun.” Another public official spoke in favor of local moonshine production on the grounds that alcohol is legal. However, he, like others in the county, saw marijuana as a symbol "of the pollution of change." 40

Floyd County natives seemed to be disgusted with newcomers who had introduced marijuana and unconventional lifestyles to the county. Local official Henry McDaniel was frustrated with the "hippie types" who he believed had come to "live off the land and run around naked.” “They grow all this marijuana,” he vented. “It just ain’t natural.” Lucas attributed the "crackdown" on local marijuana growth to "old-timers" who resented "the newcomers." "Local people are checking these places out themselves and then reporting to the police.” County officials were not the only ones criticizing the countercultural "pilgrims in a promised land"; Floyd County High School student Anthony Hayes admitted that he thought they were pretty "weird" and asserted that he and his classmates were "a pretty respectable bunch" who did not engage in illicit activities like smoking pot or underage drinking. ${ }^{41}$

Sager's article suggests that local attitudes toward the newcomers were generally negative, and those perceptions were based on a combination of factors ranging from the superficial to the serious. Marijuana, it seems, had become a flashpoint between natives and newcomers by 1981 because it symbolized a population that had rejected conventional values. But there was another cause of frustration in Floyd that was perhaps a bit simpler to understand: other newspapers and magazines had exposed the county's internal dynamics between natives and newcomers in recent months (and would continue to do so through the 2000s), so by the time The Washington Post published its version of marijuana problems in the county, locals had

\footnotetext{
${ }^{40}$ Sager, "There's Pot in Them Thar Hills."

${ }^{41}$ Sager, "There's Pot in Them Thar Hills."
} 
grown defensive of their image and officials like Branscome grew increasingly determined to clean up Floyd County.

Although marijuana was present in back-to-the-land enclaves like Floyd, many homesteaders and communitarians were quick to minimize the role that it played in their agrarian lifestyles. Homesteader Karen Kaynol retorted that marijuana "is such a miniscule part of life here ... Most of the people I know don't do pot. They don't do beer or sugar or preservatives or meat either." ${ }^{42}$ Joanie Goldsmith, a Lincoln County, West Virginia, alter-native, conceded that there was marijuana in her community and that her friends had been "pot smokers from the mid60s to late-60s," but interest in the drug waned somewhat as they began to homestead. "You can't smoke pot and get things done," she asserted. "It was more a thing you did at night when you listened to music or people are just talking quietly." She and her husband grew marijuana but only for private use. "Our group of friends," she recalled, "some of them smoked daily maybe or maybe every few days, but it just wasn't a big thing." 43

Whether or not reports of regional pot production and use were exaggerated, it is clear that some long-term residents were upset or even angry about the drug. Jeremiah Greenberg stirred up resentment even well before the Black Gold and Mountain Black Diamond battle for his support of marijuana. Indeed, the registered marijuana lobbyist had been subject to raids on at least one occasion and recalled people spitting on the sidewalk as they approached him. ${ }^{44}$ Floyd native Wanda Vest confirmed locals' fears when she recalled that many “people just didn’t like [the alter-natives] because they were into marijuana, which they thought was awful." 45

\footnotetext{
${ }^{42}$ Sager, "There's Pot in Them Thar Hills."

${ }^{43}$ Joanie Goldsmith, interview by author, Morgantown, WV, May 24, 2011.

${ }^{44}$ Jeremiah Greenberg, interview by author, Morgantown, WV, May 26, 2011.

${ }^{45}$ Wanda Vest, interview by author, Floyd County, Virginia, August 5, 2011.
} 
But while reports of marijuana busts and rumors of hippies forcing drugs on their unsuspecting communities upset some natives, others were more open-minded. One native Floydian whose husband sold property to a commune in 1971, admitted, "I wanted to see what it was like so I tried it," although her "husband never would. But I did try it, just smoked a few to see what it was like. And all it done for me was just make me drowsy and want to eat. You want to eat!” she concluded with a laugh. ${ }^{46}$ Others saw opportunities for income. In Paul Salstrom’s 1975 account of trying to find free coal, he indicated that the local Vietnam veteran who led the crusade said that local parents were "beginning to realize something's going on" with marijuana. "In fact, most of the high school guys have only just started smoking grass and growing their hair,” said the man. “The old folks are fit to tie,” he added, “'cept a few who want in on it, like my uncle here.” Mike’s uncle, an old-timer who had long produced moonshine, had just “'smoked his first grass'” and announced to the group his plans to give up moonshining so that he could "grow grass for a living.,"47

Joanie Goldsmith’s mountain patron, Henry Baker, similarly began smoking and cultivating marijuana for profit. In fact, for natives and newcomers in her immediate neighborhood, marijuana cultivated community identity and cohesion. The homesteaders in her group smoked marijuana and grew it for their own use, but not for sale, and she discovered that "the locals liked it.” Marijuana "brought us closer to them ... It was a bonding thing. It wasn't something we advertised, but there were a few people who got high with us. Like Henry [Baker] and his kids and his wife, and a couple other people.” But she was careful to clarify that "it

\footnotetext{
${ }^{46}$ Vest interview.

${ }^{47}$ Paul Salstrom, “Son of Coal," Green Revolution, November 1975.
} 
wasn't part of the culture yet ... So it was never let out in the open. Just with a few people, some of the local people that we trusted and they trusted us.”48

When asked how natives and newcomers had hybridized over the last forty years, Floyd migrant Will Bason remarked, “Locals grow marijuana.”49 Like barter, marijuana fit within indigenous underground activities like moonshining to provide another source of revenue for cash-strapped local farmers, particularly during the economic downturn of the 1970s and early 80s. It is clear from both homesteaders' accounts of the local culture and from the court cases that were published in local papers that natives cultivated the plant. ${ }^{50}$ One case in particular emphasizes this point; upon his retirement Sheriff Branscome commented that one of the most surprising busts he had made during his career involved an elderly man. He charged seventy-nine year old Edgar Lewis Hale of Copper Hill with the possession of illegal liquor, distilling equipment, and “manufacturing marijuana.”51 Lincoln County alter-native Jim Probst recalled that during his first year there, a local who he had gotten to know came up to him and pulled out "this bag of marijuana seeds and he goes, 'I just planted my crop last night.",52 After telling the story Probst wondered aloud if the county had a long history of moonshining, suggesting that marijuana would have been an easy replacement for illicit distilling.

Another alter-native, Kip Rondy, was more certain on that point; he believed that the area’s grinding poverty led local residents to consider any option, legal or illegal, that could ease

\footnotetext{
${ }^{48}$ Goldsmith, interview.

${ }^{49}$ Will Bason, interview by author, Floyd, Virginia, September 25, 2011.

50 "Couple charged after home raid,” Floyd Press, February 2, 1984; Bill Sumner, "Man, wife found guilty of drug charge,” Floyd Press, January 1, 1985. Sheriff Branscome’s aggressive campaign against marijuana in Floyd County makes it easier to examine marijuana production there than in Lincoln County. In Floyd, several significant, albeit somewhat strange, accounts of local production were published in the paper, including one case in which a fifteen year old girl assisted her neighbors' marijuana production by growing it in the basement of her parents' home. The marijuana charges against the parents were dropped, but they were charged with possession of untaxed whiskey.

51 “Copper Hill man arrested in raid,” Floyd Press, April 10, 1986; Wanda Combs, "12-year sheriff leaving office, but not retiring,” Floyd Press, December 31, 1987.

52 Jim Probst, interview by author, Hamlin, WV, March 23, 2011.
} 
their financial strain. Locals, he asserted, tolerated, and even embraced, marijuana because it provided them with badly needed income. Like Goldsmith, he also believed that it helped to strengthen neighborly bonds, for while the natives taught newcomers manual skills related to farming and machinery, the newcomers taught them about circumventing the law: “Our expertise was how to circumvent law enforcement, how to operate under the radar, because we had grown [up] in an urban environment. Police officers generally are urban people. So we knew their game.” So some alter-natives provided locals with knowledge and advice about how to grow marijuana and, perhaps more importantly, how to keep from getting caught. ${ }^{53}$

For a few regional residents, marijuana production became an attractive alternative or complement to moonshine because of robust demand, the plant's adaptability to the regional environment, and the abundance of relatively remote land required for cultivation. It may be nearly impossible to determine how many moonshiners either combined marijuana and liquor production or eventually transitioned to marijuana production exclusively, but the Appalachian region's reputation as a hot spot for pot grew after the 1970 s. $^{54}$ Some of this production was at the hands of non-residents who used public lands for cultivation. ${ }^{55}$ Rondy, for one, believed that President Reagan's crackdown on marijuana production, which had caused other states to clamp down on production, wound up causing land prices to increase in West Virginia as growers flocked there to escape surveillance elsewhere. Still, back-to-the-landers, and some native

\footnotetext{
${ }^{53}$ Kip Rondy, interview by author, Athens, Ohio, March 24, 2011.

${ }^{54}$ NORML, “NORML report on U.S. Domestic Marijuana Production: 1998 Marijuana Crop Report,” NORML marijuana production statistics, http://norml.org/pdf_files/NORML_US_Domestic_Marijuana_Production.pdf (accessed February 24, 2012). The National Organization for the Reformation of Marijuana Laws produced a report in 1997 contending that marijuana was the number-one cash crop for several Appalachian states: Virginia, Tennessee, Kentucky, and West Virginia. They base their findings on several factors, including Drug Eradication Administration statistics, state police eradication results, and the market value of marijuana as determined by High Times magazine.

${ }^{55}$ See "High Quality Marijuana Impounded," Floyd Press, September 10, 1981; Several people from the West Coast were charged with the production of 527 pounds of "very high quality" marijuana with an estimated street value of over one million dollars. It is unknown whether they had any connection to people in the existing back-to-the-land population.
} 
Vietnam veterans like Mike, played a role in shaping regional attitudes toward marijuana use and production. While many natives feared and resented the introduction of pot into their communities, others incorporated it into their lifestyles and into the region’s underground economy.

Making a Living off the Land: Agricultural and Forestry Development in Floyd and Lincoln Counties

Although marijuana flourished in regional communities like Floyd and Lincoln in the wake of the back-to-the-land migration (and also as a result of market shifts and federal drug policies), alter-natives collectively put far more effort into producing legal crops and other agricultural products for the open market. Both counties’ agricultural bases were on the decline in the late twentieth century, but institutional and political support still existed for in-migrant farmers who wanted to move beyond subsistence agriculture. But in both counties, local attitudes toward farming methods and land use were slow to change, so even as alter-natives espoused progressive visions of sustainable agriculture and forestry, they sometimes confronted reluctant public officials, as in Lincoln, or deeply entrenched attitudes toward the benefits of conventional farming, as in Floyd, that hindered their ability to forge widespread cooperative or sustainable enterprises.

“Trees and furniture, not strip coal”: The Timber Industry in Lincoln County: 
Few alter-natives farmed for self-sufficiency long-term; most nuclear family homesteaders became "market-gardeners" or transitioned their land into working farms that produced specific goods for the market. The in-migrant farmers in Lincoln County-the ones who became serious about farming as a profession—generally left the county and moved elsewhere because of the county's poor soil and infrastructure that restricted their ability to take products to market. (One man who moved to Floyd, Virginia, from West Virginia remarked, “The worst roads in Floyd are better than the best in West Virginia.”) ${ }^{56}$ Margie Shew explained that she and her husband found homesteading to be too difficult and expensive, so over time they were forced to find work off the farm so that they could continue to support it. "Homesteading is really hard," she reflected, “and as we kept adding on things . . . that cost money, like electricity, phone, [and] a reliable car, we found that we needed to work out away from the homestead.” She worked part time at a local camp and her husband found employment shoeing horses. But they ultimately wanted to work from home, and they found that good, productive land in West Virginia “was really expensive.” So they moved to southeastern Ohio after locating more farmable, and affordable, land near Athens. ${ }^{57}$

Another homesteader, Kip Rondy, followed suit. Rondy had purchased remote land in the mid-1970s and tried to make a living off of its products. He tried his hand at producing egg noodles for the Federation of Ohio River Co-Operatives, but a dispute with the organization caused that enterprise to fall through. Like many other alter-natives, he found himself having to work off the farm. Because of his educational background, he first found employment in Huntington and then worked for Catholic Community Services in Hamlin. Through his work he witnessed the vastness of local poverty. He mused that while back-to-the-landers had engaged in

\footnotetext{
${ }^{56}$ Roger Mannon, “Road hearing draws additional requests," Floyd Press, October 19, 1989.

${ }^{57}$ Margie Shew, email to author, July 1, 2009.
} 
voluntary poverty, the deep poverty that already existed in Lincoln County affected the inmigrants’ ability to make viable livings. "Eventually” the poverty “stopped being voluntary.” Further, he found that his family’s lives increasingly became about a "survival of isolation.” He and his wife had to carry food and supplies in and out of their property, it took them two hours to drive from their place to Huntington to be able to market their goods, and, he concluded, it was ultimately too difficult to do business from his farm. As his two daughters approached school age, he also grew concerned about the severely underfunded local education system. So after a discussion with Pete Shew, who had already moved to Ohio and declared it to be "unbelievably better” than Lincoln County in terms of farmable land and the economic landscape, Rondy decided to sell his farm and leave. ${ }^{58}$

There was concerted effort to bolster the county’s agricultural sector in the late 1980s and early 1990s, although interest among county leaders seemed anemic compared to their push for resource extraction like coal. ${ }^{59}$ More emphasis was placed on developing the county's forest and wood industries, although interest in that, too, was short-lived. After a year-long wait and several additional delays, the county received an economic development plan in 1987 from a Pennsylvania-based company called Nassaux-Hemsley, Inc., the first for the county since the Kennedy administration had provided federal funding for regional redevelopment in $1961 .{ }^{60}$ The

\footnotetext{
${ }^{58}$ Rondy interview.

${ }^{59}$ Paul Carson, "Planting season underway at Hamlin Demonstration Farm,” Lincoln Journal / Weekly News Sentinel, May 4, 1987; Joe Farruggia, “Farm Trail, Inc. leases the demo farm,” Lincoln Journal, January 16, 1991; Joe Farruggia, “Demonstration farm opens permanent produce market,” Lincoln Journal, July 24, 1991; Tara Tuckwiller, "Earning their wings landing on the path to new airport, Lincoln County has a long way to go,” Charleston Gazette, March 7, 1999. More research needs to be conducted on the development and evolution of the Lincoln County Farm Trail Co-operative.

${ }^{60}$ Bruce Carter, “1961 development association failed in effort,” Lincoln Journal, February 18, 1987. Apparently there were some problems with the Lincoln County Development Association, an organization started as part of President Kennedy's area redevelopment plan; according to Lincoln Journal, the county raised roughly \$20,000 to purchase property so that it would attract a brassiere plant, which was paid roughly an equal amount to open. The plant remained in business for fifteen years and employed around 100 people but closed as a result of "union and other troubles." Profits from the plant were supposed to have been "reinvested to attract more businesses to the
} 
plan acknowledged local efforts to diversify agriculture and recommended that the county start to process tobacco locally, but its top recommendation (in addition to two seemingly contradictory industries: surface mining and tourism) was the development of a small business incubator, supported by state and federal funding, that could nurture woodworking and wood manufacturing enterprises. The report noted that at one time the county had supported fifty local sawmills that produced roofing timbers for mines in other counties. But the mills had largely disappeared with the decline of the underground coal industry following World War II. The plan recommended "exporting logs and lumber, pulp logs, wood flooring, wood craft (including furniture), and veneering” in addition to establishing a research and development center, installing kilns, and building a storage facility within the county's borders. The point of the wood industry was to provide the county with economic "self-reliance" and employment. Rather than ship forest products out of the community to other facilities for processing, the county needed to find ways to encourage processing within its borders. A “wood preservative plant,” it claimed, could expand employment in the timber industry by as many as 1,000 people. ${ }^{61}$

There was a short period of cooperation and support for the development of the timber industry in Lincoln County following the report. Business leaders met after its release to discuss solutions to the county's economic woes, particularly the issue of renewed outmigration. Hamlin’s Mayor C.E. Monday had recently invested money in a large kiln to treat lumber, so he

county," but, according to one former member of the Association, "were lost or misplaced or pocketed by someone." So the county never reaped the benefits of the program.

${ }^{61}$ Bruce Carter, "Surface mining optional: Plan points to timber for future development," Lincoln Journal / Weekly News Sentinel, February 18, 1987; Paul Carson, “\$29,000 Price tag: Report gathering dust," Lincoln Journal / Weekly News Sentinel, March 15, 1989; Bruce Carter, “Association plan reviewed,” Lincoln Journal / Weekly News Sentinel, February 18, 1987. Two years later there seems to have been little follow through with the plan's recommendations on any front. In the spring of 1989 a reporter questioned local officials who had agreed to pay $\$ 7,400$ to match a federal grant for the report about what actions had been taken to bolster the local economy. "How wise was the investment?" questioned Paul Carson. The men interviewed expressed their disappointment with the report but ultimately backed their decisions to use it on the grounds that they now had "a plan on record ... of what" needed to be done. 
was particularly interested in developing other sectors of the wood products industry in the county. Alter-native Jim Probst, who came from a woodworking family in Indiana, had just moved his business out of his home and into a shop located above the hardware store in Hamlin. He looked forward to having a ready supply of treated lumber from Monday. The Lincoln Journal's editor lauded the businessmen's efforts, maintaining his "hope” that they would “continue on this positive trend at the next meeting” and ultimately "continue to pursue the hardwood products field as a potential economic boost for this area.”,62

In spite of his support for the timber industry, the editor remained skeptical about the economic development report's potential to effect lasting change. He was irritated by its late arrival and also believed that it offered few new insights beyond what had been said thirty years earlier. Others asked similar questions. Mayor Monday was allegedly vexed by an interview that Lincoln County Clerk Larry Z. Adkins, who was also the head of one of the county’s two Democratic factions, had given to the Charleston Gazette, maintaining his skepticism about wood resources as a viable economic alternative. He believed that while the county had “potential in woodworking and wood products,” the wood industry would "do better in the South, in Virginia, and in North Carolina.” Adkins’ recommendation instead was to build an industrial park in the county and to encourage coal mining, although even with those sentiments he too remained skeptical that the county would see any immediate economic improvements. “The economy has been so stagnant for years,” he could not envision “any specific upturns.”63

\footnotetext{
${ }^{62}$ Editorial, "Business applauded,” Lincoln Journal / Weekly News Sentinel, February 25, 1987; Bob Schwarz, “Two woodworkers set up shop in county,” Lincoln Journal / Weekly News Sentinel, May 4, 1987.

63 “The Gatepost," Lincoln Journal / Weekly News Sentinel, March 2, 1987. As mentioned in Chapter 5, the late 1980s were disastrous for rural Appalachia; West Virginia faced a severe economic crisis and in the early spring of 1987 anticipated being " $\$ 75$ to 80 million in the hole" by the end of the fiscal year. See Bob Schwarz, "Financial disaster threatens,” Lincoln Journal / Weekly News Sentinel, March 18, 1987.
} 
For the first several months of 1987 the newspaper ran a slew of articles to profile developments in the wood industry, including an interview with a local forester, a second examination of Jim Probst's shop and another woodshop that had similarly opened near the county seat, and a profile of a couple who had moved to the county (and declared themselves to not be "back-to-nature" types) to start a tree farm. ${ }^{64}$ The introduction of surface mining into the community's economic consciousness shifted the conversation, however, and the paper increasingly ran articles on coal rather than timber. P\&C Bituminous Coal started its operation amid relatively weak protests, and once Black Gold and Mountain Black Diamond expressed interest in mining near Hamlin, any remaining talk of developing the wood industry came from anti-strip mining parties eager, and perhaps desperate, to present local leaders with other options.

While not everyone who advocated forest products was necessarily part of the campaign against surface mining, several movement leaders pointed to forestry as a viable alternative. Paul Salstrom wrote about this in his article, "Cash is a Four-Letter Word.” His brother and other members of Home Place had delegated to Paul the task of researching timber as a possible economic alternative to mining. In some ways it was a natural solution for the Salstroms, for like Probst, members of his extended family owned a woodworking business. And while Paul confessed that he had worked for the family business so as to afford Lincoln County land, John had carved out a career as a carpenter. ${ }^{65}$ Other in-migrants supported timbering as well. In November of 1987, Jim Chojnacki warned of the permanent destruction that surface mining could wage upon county land. He recognized Probst’s new woodworking shop as a “hopeful sign

\footnotetext{
64 "Says local forester: Timber can be cash crop,” Lincoln Journal / Weekly News Sentinel, March 18, 1987; Schwarz, “Two woodworkers”; Paul Carson, "Tree farm blossoms on Lower Mud,” Lincoln Journal / Weekly News Sentinel, October 21, 1987.

${ }^{65}$ Salstrom, "Cash is a Four-Letter Word"; John Salstrom, interview by author, Branchland, West Virginia, December 18, 2008. Paul Salstrom noted in an email that the family woodworking business actually belonged to an uncle rather than to a member of his nuclear family, but he and several other Lincoln County alter-natives had worked there to save up money for "Lincoln County expenses.” Paul Salstrom, email to author, March 20, 2013.
} 
of the emergence of a hardwood industry in Lincoln County. The jobs and income,” he predicted, “will ripple to and from such an establishment, from land and tree owners to logger to sawmill and other furniture producers.” But he believed that Black Gold threatened that symbiotic economic relationship. “Trees and furniture,” he recommended, “not strip coal, non-union coal at that! Deep mine our coal and leave the trees to grow." ${ }^{66}$ Brad Jones, who had moved to the county in 1986, asserted that one of the primary reasons for doing so "was because there was no mining being done here and the future of the county seemed tied to agriculture and timber industries.”67

Even as county leaders remained focused on mining for the next several years, there is some indication that the county's woodworkers enjoyed a degree of success. By 1989, the Lincoln Journal indicated in a special feature on Jim Probst that the alter-native's business had grown. The cabinetmaker had moved his shop from Middle Creek to downtown Hamlin, and he received visitors almost weekly from Charleston and Huntington who were interested in his work. Probst, who asserted that he would have preferred to remain a “one-person shop,” was so successful that he hired two additional employees. He was in a good location for obtaining cheap raw materials, like native-grown cherry, maple, and ash, and according to Paul Salstrom, his business had been bolstered by "socially-motivated loan money." ${ }^{68}$ Probst, like Chojnackin and others, opposed surface mining and hoped to develop "the wood industry . . . because wood is a renewable resource.”69

But the county's timber and forestry product industry as a whole had not fared as well, for on the same day, the newspaper also published an article questioning the results of the

\footnotetext{
66 Jim Chojnacki, “Wood, yes, strip, no,” Lincoln Journal / Weekly News Sentinel, November 18, 1987.

${ }^{67}$ Brad Jones, “No future with short term gain,” Lincoln Journal / Weekly News Sentinel, February 17, 1988.

${ }^{68}$ Salstrom, "Cash is a Four-Letter Word."

${ }^{69}$ Lisa Graley, “Cabinetmaker Jim Probst: Building on a dream,” Lincoln Journal, March 15, 1989.
} 
economic development report that had been conducted two years earlier. As mentioned above, even at the time of the report's release, some community leaders questioned its value, arguing that the data it provided presented little new information or insight. The same questions resurfaced in the 1989 article, and one local leader confessed that he had hoped for more "ideas on how to bring the private enterprise in here—-how to get that wood plant started.” And while the leaders who had commissioned the report continued to support their decision, they blamed disappointment in its results on high expectations. "Don’t get me wrong,” said former commissioner A.J. Stowers, "I think we did get what we paid for, and it was money well spent because that plan is there on record now. But I think because we were so desperate and our expectations were so high, we were kind of suckered into the program.,70

\section{“Nutrient-belief differences”: Floyd's Changing Agricultural Landscape}

"Small farms in Virginia and elsewhere, in general, experienced significant declines in the profitability of their farms," reported the Floyd Press in June of 1991, "as prices for inputs such as fertilizers, equipment, pest controls, and fuel have risen dramatically.” Indeed, the dominant trend across the Blue Ridge during the waning decades of the twentieth century was the replacement of farmland with subdivisions, gated communities, and vacation homes. ${ }^{71}$ Many

\footnotetext{
${ }^{70}$ Paul Carson, “Report gathering dust; \$29,000 price tag,” Lincoln Journal / Weekly News Sentinel, March 15, 1989; James Heffern, “Town fee passed.” It appears that at the time of that article, the county was still desperate, for another report indicated that because of financial problems Hamlin had to impose a three dollar per month tax on city residents just to keep its two-person police force and to maintain other services.

71 “A Small Revolution in Food Production,” Floyd Press, June 6, 1991; Richard D. Starnes, Creating the Land of the Sky: Tourism and Society in Western North Carolina (Tuscaloosa: University of Alabama Press, 2005), 7;

Patricia D. Beaver, Rural Community in the Appalachian South (1986; repr., Prospect Heights, Illinois: Waveland Press, 1992); John B. Stephenson, "Escape to the Periphery: Commodifying Place in Rural Appalachia," Appalachian Journal 11, no. 3 (Spring 1984): 189-190. This process unfolded in different areas of the Blue Ridge at different times. In some areas of western North Carolina, the development of resorts extended back to the nineteenth century. In others, it occurred during the mid-to-late twentieth century. Patricia Beaver and John Stephenson both
} 
debt-ridden and cash-strapped farmers like Wanda Vest and her husband could ill afford to keep their land. As one east Tennessee native lamented, "Of course, the farmers cannot be blamed much--a million-dollar buyout sounds a lot better than trying to make ends meet for another 20 harvests and then losing it all to the bank during their retirement years."72 Places like Floyd County attracted wealthy retirees and second homeowners as well as to a new crop of back-tothe-landers because of its growing reputation as a countercultural haven and because it offered relatively easy access to scenic vistas, recreation, and high-quality health care in surrounding urban areas. The resultant escalation of land prices and property taxes made farming increasingly cost prohibitive, so some Floyd farmers, particularly those on the edge of the county near Interstate 81, sold to developers who then turned farmland into subdivisions. Seasonal homeowners also purchased land along the Blue Ridge Parkway. ${ }^{73}$

As a testament to the level of farm decline that had occurred during the twentieth century, writer Jim Minick, who moved to the county in 1990 to start a blueberry farm, examined some aerial photographs of his neighborhood dating back to 1937. In that year, there were ten other homes, but by 1991, five remained, "two as summer homes." Only one, he added, "was still a

observed land price escalation in their communities of study. Stephenson maintained that the rising price of land, while still affordable for middle class buyers, had priced many natives out of their home communities. This process unfolded earlier in the more rugged mountains of North Carolina, but as land prices escalated there, the trend moved northward into the rolling hills of Virginia.

72 Abe Whaley, "Soon a Place Like Any Other: It's Heartbreaking to Watch the Appalachia I Love Disappear Under Endless Condos and Cabins," Newsweek, November 14, 2005, 13.

${ }^{73}$ United States Department of Agriculture, “Quick Stats,” Floyd County, Virginia, http://quickstats.nass.usda.gov/results/86CBBCEC-A29C-3A51-8173-B0370DC5C457 (accessed January 21, 2013); Amer Awad, "Please, Don’t Tread on Me: A Case Study of a Dairy Farm in the Appalachian South," http://anthro.appstate.edu/field-schools/papers/2007/awad (accessed February 6, 2013). Floyd County planner Lydeana Martin noted that between 2000 and 2011, one thousand residential lots had been created out of farmland. There had been some wild fluctuations in Floyd's dairy industry between the late 1990s and late 2007s that may have contributed to the sellout to developers. In 1997, there were nineteen dairy operations that had \$3.6 million in sales. By 2002, sales declined significantly to approximately $\$ 2.5$ million while the number of dairies had increased to twenty-one operations. Yet the dairy industry appeared to have rebounded somewhat in the next five years; the county reported thirty-two operations in 2007 that sold \$3.7 million. But the volatility of the market for small dairy operations likely prompted many farmers to sell when they saw the opportunity. More research needs to be conducted to determine the factors that may have led to the turnaround and whether or not this was consistent across the Virginia Blue Ridge, traditionally a dairy-producing area. 
working farm." ${ }^{74}$ There were adverse social and cultural effects of this transition away from farming. Traditional networks of community and family that served support roles for farmers broke down, as younger generations of Appalachians moved away to find employment elsewhere. In addition to declining revenue, systems of community reciprocity and family support deteriorated in many areas like Lincoln and Floyd counties. Ronald Eller reflects on this broader regional shift and the effects it had on mountain communities. "The land had always shaped human relationships and personal identity. It had always defined cultural meaning. The loss of farms and of farm life, the enclosure of the forests for private use," the environmental destruction, the "uprooting of families," and the "congestion of people in once quiet places were for many Appalachians high costs to pay for material convenience and comfort." ${ }^{75}$

Both multigenerational and newer Floyd residents recognized what they stood to losethe former because of decades of outmigration and farm decline and the latter because of their distaste for the congestion and pollution of urban areas—and so they were unified in their desire to prevent additional farm decline. Although it has faced challenges in recent decades, agriculture and the rural character of the county is still central to Floyd residents; a recent survey found that the vast majority of residents want to preserve area farms and minimize development. As mentioned in previous chapters, the alter-natives frequently expressed their desire to see Floyd County remain predominately rural and agricultural. At times the issue of job creation versus environmental protection sparked community conflict, but the alter-natives' desire to preserve elements of Floyd County's rural heritage also helped to forge alliances. ${ }^{76}$ The survey

\footnotetext{
${ }^{74}$ Jim Minick, The Blueberry Years: A Memoir of Farm and Family (New York: Thomas Dunne Books, 2010), 41.

${ }^{75}$ Ronald D. Eller, Uneven Ground: Appalachia Since 1945 (Lexington: University of Kentucky Press, 2008), 255.

${ }^{76}$ Kathleen M. Brennan and Christopher A. Cooper, "Rural mountain natives, in-migrants, and the cultural divide," The Social Science Journal 45 (2008): 292; Beaver, 120. One study from Western North Carolina suggests that while natives in that area maintained a higher reverence for cultural heritage than in-migrants, the longer the inmigrants remained, the more likely they were to appreciate the locals' cultural heritage as well and to become
} 
found that regarding environment and land use, the "greatest consensus was reached" on the issue of farmland preservation. The vast majority of residents wanted to preserve the county's rural character (68\%), promote and preserve local agriculture (83\%), protect farmland (76\%), and stave off the development of subdivisions (63\%). ${ }^{77}$

How to go about preventing farm decline and preserving the county's rural character, however, was up for debate. Floyd in the 1990s was only in the early stages of revitalizing its downtown, but already there were contrasting opinions about what types of businesses and farms and industries should be allowed. This is not uncommon for communities in transition; they are often faced with difficult decisions about how to navigate development in ways that can preserve their agricultural roots and traditional communal networks that provide long-term residents with a sense of security, familiarity, and well-being. ${ }^{78}$ Sociologists recognize these differing visions as being either more "local" or else more "cosmopolitan" in nature. But these terms should not suggest a community leader's influence over any particular locality; instead they “refer to the nature of the issues the two types of influentials will espouse.” The local is typically concerned with "local issues" and can be rather "parochial in scope of interest and activity," while the cosmopolitan recognizes the broader impacts and influences of local decision-making. ${ }^{79}$

Floyd County has experienced multiple waves of back-to-the-landers, the first of which occurred in the 1970s. Some trickled in through the 1980s, but reflecting a larger trend of

protective of the area's rural quality. Even in the early years of the back-to-the-land migration, however, Patricia Beaver recognized that there were some commonalities between the ways in-migrants and natives viewed the land. Natives who decided to sell their land often went to members of the back-to-the-land community first to look for buyers rather than selling to "developers or summer people." They realized that the alter-natives were more accepting of the local culture and less likely to dramatically alter the landscape.

${ }^{77}$ James Howdon and John Ryan, "The Floyd County Community Survey,” Blue Ridge Institute for Community, August 2005, 6.

${ }^{78}$ Brennan and Cooper, "Rural Mountain Natives"; Patrick C. Jobes, Moving Nearer to Heaven: The Illusions and Disillusions of Migrants to Scenic Rural Places (Westport, Connecticut: Praeger, 2000), 210.

${ }^{79}$ Emilia E. Martinez-Brawley, Perspectives on the Small Community: Humanistic Views for Practitioners (Silver Spring, MD: National Association of Social Workers Press, 1990), 78. 
migration back to urban areas, the movement subsided during that decade. Yet the 1990s saw renewed nonmetropolitan growth, and Floyd attracted additional New Age types, artists, homesteaders, and a new crop of serious farmers—not just folks seeking independence or selfsufficiency. These farmers relocated to Floyd County for many of the same reasons - the area's temperate climate, topography, and culture, as well as for its growing reputation as a place with environmental sensibilities and reverence for agricultural heritage_-although the emergence of the strong alternative community over the last twenty years also played a major role. Some new in-migrants, for example, moved after having attended Harmonic Conversion celebrations in Floyd in 1987, while others came as a result of the ERC's newsletter, nicknamed the "Museletter,” that was used as a recruiting tool. About half of the Museletter's readership in 1990, in fact, was non-local. “We’ve been getting the ERC Newsletter for awhile,” wrote Jan Peterson in 1987. “We are anticipating a move to Floyd County. We're closely in touch with Travianna and we really appreciate getting the newsletter.”, 80

This new wave of in-migrants shared with the existing alter-natives concerns about nurturing the local economy, protecting the environment, and preserving the county’s rural character for future generations_all signs of their decidedly “cosmopolitan” outlook. Many of

\footnotetext{
${ }^{80}$ Kenneth M. Johnson and Calvin L. Beale, "The Recent Revival of Widespread Population Growth in Nonmetropolitan Areas of the United States," Rural Sociology 59, no. 4 (1994): 655; "Historical Populations for Lincoln County, West Virginia,” Wikipedia, http://en.wikipedia.org/wiki/Lincoln_County,_West_Virginia; "Historical Populations for Floyd County, Virginia," Wikipedia, http://en.wikipedia.org/wiki/Floyd_County,_Virginia (accessed January 21, 2013); Jan Peterson, "ERC Folks,” The Educational Resource Cooperative Newsletter, November 1987. Kenneth M. Johnson and Calvin L. Beale observed a broad trend of nonmetropolitan growth in the early 1990s. They reported that "more than 64 percent of the 2,277 nonmetro counties" in the United States "gained population between 1990 and 1992, compared with only 45 percent in the 1980s." Although Lincoln County continued to attract a few young and energetic agriculturalists during the 1980s and 1990s, it paled in comparison to the continued in-migration of New Agers and idealistic young farmers (and retirees) who flocked to Floyd County beginning around 1990. In fact, the few people who migrated into Lincoln County did little to stem the tide of renewed outmigration. Between 1980 and 1990, the county experienced a 9.7\% drop in its population. It rebounded slightly between 1990 and 2000, with a 3.4\% population increase. Compare that to Floyd, which experienced growth, albeit slowed, at 3.8\% between 1980 and 1990. But then, between 1990 and 2000, Floyd County's population growth rate approached its 1970s rate (18.3\%) with a 15.6\% increase.
} 
them also reflected a growing nationwide interest in reviving small family farms. They were part of a variety of burgeoning movements that at the time might have seemed obscure but are now fixtures in the American lexicon: the "Slow Food" movement, organic farming, the "Locavore" movement. And they, combined with the earlier generation of back-to-the-landers, likewise made incremental impacts on the social, cultural, and economic landscape in Floyd.

The solutions the new alter-natives proposed for maintaining and supporting family farms emerged out of growing concerns about the disconnect between consumers and producers, foodborne illnesses, the decline of small family farms, industrial agriculture, and a general lack of availability of and interest in quality food. The older generation of alter-natives repeatedly voiced similar concerns, but the solutions they proposed were often not as clearly defined as they became in the 1990s. Prior to that they had been more about personal choice, not institutional action. That changed somewhat as the first wave alter-natives became engrained in the community and began to take on leadership roles. They supported high quality food, local food production, farmers’ markets, the elimination of pesticides, and organic gardening. Still, it appears that the newer agriculturalist in-migrants came with elevated awareness of a growing international movement that could provide, in theory, "a radical alternative to a hegemonic food system.” ${ }^{81}$ They brought with them a new set of tools gleaned from international trends to answer some of those concerns, including “direct marketing," which is selling farm products directly to the consumer, organic food markets, and Community Supported Agriculture, or CSA. These concepts are collectively referred to as “alternative food networks.” AFNs were meant to

\footnotetext{
${ }^{81}$ Julie Guthman, Agrarian Dreams: The Paradox of Organic Farming in California (Berkeley: University of California Press, 2004), 3; Amy Trauger, "Un/Re-Constructing the Agrarian Dream: Going Back-to-the-Land with an Organic Marketing Co-Operative in South-Central Pennsylvania, USA," Tijdschrift voor Economische en Sociale Geografie 98, no. 1 (2007). Guthman and others charge that in some ways the organic food movement has fallen short of its ideals. Citing unjust labor practices, the continuation of market capitalist systems through organic farming, and environmental problems such as the creation of monocultures, they argue that organic farming in reality may be little better than conventional.
} 
"re-order and shorten commodity chains to stimulate local markets, improve availability of 'quality food,'” promote farmer / consumer interaction, and "contribute to rural development."82

Polly Heiser, a native Virginian who moved to Floyd in 1990, was the first to launch a local CSA. There were only two others at the time in the entire state of Virginia: one in Fincastle and another in Charlottesville. ${ }^{83}$ Heiser and her partner at the time, Ron Juftes, both came with agricultural backgrounds; they had owned a landscaping business prior to purchasing their 111acre farm (formerly Curtis Vest’s dairy farm) in Floyd called Seven Springs. Both were trained in horticulture, and they worked with another in-migrant, Mark Schonbeck, who specialized in sustainable agriculture. Prior to moving to Floyd, Schonbeck worked for the New Alchemy Institute on Cape Cod, conducting surveys and other means of evaluating vegetable growers' operations. $^{84}$

The CSA concept was first formally introduced to the Floyd community in 1991. Heiser wrote a press release to the Museletter explaining the history and purpose of the movement. CSAs were initially developed in Switzerland, but an American, Jan Vander Tuin, is credited with introducing the idea to America. They emerged from a convergence of consumer and producer concerns for environmental quality, physical health and well-being, food security and safety, and economic support for small family farms, and, like the Alternative Food Network movement more broadly, were a reaction to centralized food production. Reflecting these concerns, Heiser wrote, “Large corporations have taken over food production using many petroleum based inputs, most of which are toxic and polluting.” While many people wanted alternatives to mass-produced "fast food," most had little time or space to cultivate gardens. And

\footnotetext{
${ }^{82}$ Trauger 11.

83 “A small revolution in food production,” Floyd Press, June 6, 1991.

${ }^{84}$ Wanda Combs, “Gardeners promoting community agriculture,” Floyd Press, March 14, 1991.
} 
organic produce offered in grocery stores was often cost-prohibitive. "CSA is a wonderful alternative to this dilemma,” Heiser concluded. ${ }^{85}$

CSAs offered a variety of produce year-round, from fresh vegetables in the summer to "storage crops" in the winter, and provided farmers with living wages. Development of CSAs typically began with the formation of non-profit organizations that could secure "land suitable for growing a large garden” and could hire employees to "grow and distribute the food.” CSA farms could feed a significant number of people, between thirty and 200, who would purchase "shares" of the harvest before the growing season began. One share "is designed to feed a family of one to three" and the price of each share would be "determined by dividing the actual cost of growing the food by the number of shares purchased.” CSA members would receive a weekly supply of food throughout the season. ${ }^{86}$ The farmers benefited as well, explained Vicki Karagianis to the Floyd Press, because they had "guaranteed income that allows him or her to proceed with planting without having to obtain loans and with the assurance there will be a market for the products.” Most importantly, both parties benefited because the arrangement fostered relationships between farmers and consumers. ${ }^{87}$

In spite of her efforts, Polly Heiser had some initial difficulty building interest in her CSA. "We used to have to beat the bushes to get people," she recalled. Ron Juftes estimated that Seven Springs started with “maybe eighteen members” and by the next summer had grown "to thirty-five.” Heiser recruited members through both the Museletter and the Floyd Press, and she

\footnotetext{
85 "Seven Springs Farm: Meet the Farmers,” Seven Springs Farm, http://csa.7springsfarm.com/meet-the-farmers/ (accessed January 24, 2013); Polly Heiser, “Community supported agriculture at Seven Springs Farm,” The Museletter, February 1991; Steve Martinez, et. al., Local Food Systems: Concepts, Impacts, and Issues (Washington, D.C.: United States Department of Agriculture, Economic Research Service, Economic Research Report Number 97, May 2010), 2.

${ }^{86}$ Heiser, "Community supported agriculture at Seven Springs Farm."

87 “A small revolution in food production," Floyd Press, June 6, 1991.
} 
sponsored informational meetings at Seven Springs to answer people’s questions. The idea eventually took off, for by 1995, it had eighty members, and sixteen years later, the Seven Springs CSA had such a high demand for its produce that it had to turn people away. In the meantime, other CSAs formed in the county including the Good-Food, Good People CSA and Blue Ridge Growers’ Collaborative CSA. ${ }^{88}$

According to Juftes, "few natives” were ever "involved with the CSA.” Alter-natives and residents in nearby urban areas made up the vast majority of its membership. ${ }^{89}$ Sustainable agricultural conferences that discussed CSAs and other forms of "direct marketing to consumers," such as the Sustainable Agriculture Conference held in Williamsburg, Virginia, in March of 1994, generally consisted of newcomers. The information sessions at the Barter Faires and the increased discussions about local food production likewise did little to pique locals' interests. The reason for this, Juftes believed, was that since most locals kept their own gardens, they had little need to participate in community supported farming. Further, he added, their diets were fairly limited—corn, beans, and tomatoes—and CSAs typically offered a wide variety of foods ranging from the standard to the exotic. Many of the crops, like "multicolored carrots" or ““red-ribboned dandelion greens'” were simply not appealing to local palates. ${ }^{90}$

As with CSAs, natives were also slow to embrace organic food production. Jim and Sarah Minick moved to southwest Virginia so that Jim could obtain a master's degree in creative

\footnotetext{
${ }^{88}$ Lindsay Nair, "Community Supported Agriculture Programs in Southwest Virginia,” Roanoke.com, http://www.roanoke.com/columnists/nair/wb/232740, (accessed January 21, 2013); Wanda Combs, "CSA begins new season," Floyd Press, February 16, 1995.

${ }^{89}$ Ron Juftes, interview by author, Floyd, Virginia, July 16, 2011; Wanda Combs, "CSA begins new season.”

90 "Vegetable farming discussed at Sustainable Ag Conference," Floyd Press, March 10, 1994; Lindsay Nair, "Sharing the Harvest," Roanoke.com, under "Community Supported Agriculture," http://www.roanoke.com/columnists/nair/wb/232735, (accessed January 21, 2013). The incorporation of organic farming in the 1990s and 2000s was likely due to the convergence of several factors in addition to alter-natives' presence in the county: growing national awareness about pesticides and GMOs, increased availability of resources and information on the internet to facilitate organic gardening, and the increased profitability of organic produce.
} 
writing from Radford, but they decide to stay because they loved "the mountains and valleys, the rural nature of land and people, the fertile possibilities." ${ }^{\text {91 }}$ For a decade following their move they ran an organic blueberry farm in the county, and Jim chronicled their experiences in his memoir, The Blueberry Years. Like earlier alter-natives, Jim and Sarah cultivated a relationship with one native neighbor, Joe, who appeared in the narrative as a literary foil. Natives' consciousness regarding pesticides and other unsustainable farming practices was elevated through the FEAT campaigns and other initiatives, but attitudes about agriculture were slow to change. One of Minick's recollections about an exchange with Joe highlights the point. Joe, like many other native farmers who came into contact with naïve but eager homesteaders, liked to offer agricultural advice. “Joe’s ‘advice’ usually focused on farming,” said Jim.

He commiserated about the deer and coons and identified weeds for us ... When we broached our nutrient-belief differences, he’d shout, 'You want to farm just like my grandmother, Jim: no spraying, no fertilizer, no nothing.' He praised the modern chemicals that had kept him in red fields of strawberries for over forty years. ('Just a little Roundup won't hurt.') Several times he told me about using DDT in the 1950s, following the directions, fogging the whole kitchen—dishes, cabinets, and sink—to kill the flies. He now knew the danger, wondered why he never got sick, questioned why a neighbor, who in his words was '100 percent organic,' died in her late thirties to cancer. ${ }^{92}$

Joe viewed himself as the progressive compared to Jim, who preferred to farm without chemicals. Joe never became organic, but he was impressed when, years later, he visited Minick's berry field. He was impressed enough, in fact, to begin growing some of his own

\footnotetext{
${ }^{91}$ Minick, 12.

${ }^{92}$ Minick, 47.
} 
plants. But when Jim visited Joe's patch, he saw laid out beside the plants a bag of “10-10-10"

(phosphorous) fertilizer. "You just can’t win,” Joe jokingly told Jim. "You know that.”93

How in-migrants’ alternative food networks and concerns for preserving the land shaped natives’ attitudes toward these concerns is difficult to determine. If we go by Minick’s example, natives were slow to adopt organic farming or gardening practices. In the late 1980s, local dairy farmers seemed hesitant to embrace organic production. David Ingram and Jimmy Connor both declared their continued support for using chemicals because of concerns about weeds and the elevated costs associated with organic farming. "Milk prices are going down,” stated Connor, "and with the drought, beef prices are going down. We have to get more production off the land to stay in business, and that would be impossible to do without chemicals." "I honestly believe that if they took the chemicals out of the market, the country would starve to death,” said another farmer. $^{94}$

However, it is also likely that throughout the 1990s and into the 2000s, natives, like the rest of America, gradually learned more about the detrimental effects of pesticides on people's health and the environment, thanks to increased access to information and to the back-to-the-land movement. Indeed, as Ryan Edgington argues, the nationwide back-to-the-land movement

\footnotetext{
${ }^{93}$ Minick, 246-247, 282, 59. Minick also told a story about a visit to a local alter-native’s pick your own site that had bags of conventional fertilizer laying around the grounds. "So much for my stereotypes of the 'alternative' in alternative community," he concluded.

${ }^{94}$ Wanda Combs, “Trouble in the air? Part 1 of 3 and Part 2 of 3” Floyd Press, July 21, 1988 and July 28, 1988. As for the economic impacts of CSAs and organic farming on the county, this too requires more research. The USDA finalized its standards for organic production in 2002, so data on the profitability of organic farming prior to that year is difficult to obtain. Jim Minick asserts that in 1990, "organic food and beverages represented $\$ 1$ billion in sales in the U.S. market," but by 2007 "that figure rose to roughly $\$ 20$ billion.” In 2002, only six certified organic crop operations were in business in Floyd County. Minick's blueberry farm was the first certified organic operation in the county (1997) and the first organic blueberry enterprise in the entire state. By 2007, Floyd hosted ten certified organic farms with an additional four working on certification. Total sales for both organic and conventional crops by that time, however, were robust at nearly nineteen million dollars over twelve million a decade earlier, suggesting that a rising demand for locally produced food, likely assisted by the development of the CSAs and the several farmers' markets that dotted the county, had helped to revive small-scale farming in Floyd. Minick, 100-101; USDA, “Quick Stats,” USDA, http://quickstats.nass.usda.gov/results/D263FCBB-50DF-3BFE-8A495467F6BE8AA2 (accessed January 21, 2013); USDA, “Quick Stats,” USDA, http://quickstats.nass.usda.gov/results/612821F7-D824-3A59-BECB-F99D250BD174 (accessed January 21, 2013).
} 
contributed to, if not led, the development of a more ethical and health-conscious consumerism that was digestible for the masses. If attitudes have changed in rural communities like Floyd over the last forty years, and especially over the last twenty, the trend likely resulted from more than just health- and environmentally-conscious in-migrants: the growing availability of organic products and elevated awareness about pesticides that came from mass media and the Internet. Behind this development, says Edgington, was the watered down remnants of the back-to-theland movement now divorced from its self-sufficient hard work ethic but nonetheless still concerned with high quality food and environmental preservation. The back-to-the-landers created an ethical form of consumption that "wedded the health of nature with that of the human body.” The consumption of good, wholesome, and organic foods became part of a new “environmental consumer movement." And it was because of consumer demand fueled by the information revolution that conventional grocery stores began carrying organic products on their shelves and consumers began to focus once again on local products. ${ }^{95}$

Concerning land protection, locals were interested in actively protecting and preserving farmland and the rural character of Floyd County, as suggested above, although they were far less likely to join organizations or to devote time to activism on such issues. ${ }^{96}$ Natives and alternatives were more united on this than any other issue. Ed Gralla indicated that there was even native support for rather drastic preservation measures like land trusts. While entering a land

\footnotetext{
${ }^{95}$ Ryan H. Edgington, “'Be Receptive to the Good Earth': Health, Nature, and Labor in Countercultural Back-tothe-Land Settlements," Agricultural History 82, no. 3 (Summer 2008): 300. Ryan Edgington contends that the "back-to-the-land pursuit of the benefits of nature through labor ultimately declined" after the 1970s, leading to the creation instead of more ethical forms of mass consumption that nodded to the back-to-the-land ethos but catered to mainstream American consumerism.

${ }^{96}$ Robert Emmet Jones, et. al., “Green Migration into Rural America: The New Frontier of Environmentalism?” Society and Natural Resources 16 (2003): 235; Cathryn McCue and Madelyn Rosenberg, "Faces of Floyd County's old-timers and New-Agers are united by their love of the land," The Roanoke Times, September 22, 1991. There is also evidence that the old-timers quickly embraced recycling. The Roanoke Times reported that after recycle centers were established in the county, "old-timers started lugging in boxes of baby-food jars and newspapers from the '40s."
} 
trust could cost local families hundreds of thousands of dollars they could otherwise garner through land sales, these individuals recognized the long-term value of preserving farmland. That is, they embraced more cosmopolitan outlooks. Gralla noted that members of both the Shelor and Vest families put their land into conservation easements. ${ }^{97}$ While individuals willing to go to such lengths remain a minority, they hint at an expanded consciousness regarding land use and protection that resulted from the back-to-the-land movement. ${ }^{98}$

But it appears that the AFNs in Floyd might have done more to shape the identity and character of the county's alternative sub-community than anything broader. Conferences and workshops that were held through the 1990s addressing concerns about agribusiness, the decline of small farms, and pesticide use held more appeal to in-migrant homesteaders, "farmers and market-gardeners," than they held for the county's old-time dairy farmers and organic naysayers like Joe. In one conference press release, it was observed that farmers for years had "maintained a more or less independent existence with occasional aid from the local extension agent or fertilizer salesmen.” But the new wave small farmers intended to cultivate "networks. . . to talk about their problems and successors, share information about production, and investigate new forms of cooperative marketing and purchases." ${ }^{\text {999 }}$ Seven Springs offered workshops on soil health and composting, while annual "Grower to Grower" conferences typically catered to inmigrants' interests in sustainable agriculture. At one conference in January 1993, for example,

\footnotetext{
${ }^{97}$ Gralla interview.

${ }^{98}$ Howdon and Ryan, "The Floyd County Community Survey,” 39-40. Change is incremental, however. In 2005 only thirty-six percent of people who had lived in the county more than forty years were in favor of land use planning that could preserve natural resources, and only thirty percent were in favor of general land use planning. 99 "Conference features new farming ideas," Floyd Press, February 9, 1995. According to Ryan Edgington, it was this type of activity - networking through conferences, workshops, and cooperative meetings- that helped to bridge the gap between the self-sufficient ideal of the back-to-the-land movement and the more modern "consumer environmentalism." He believes that it was the "independent cooperative markets" and farms that "challenged traditional market-consumer relationships by encouraging cooperative ownership, hosting workshops, and offering discussion groups on organic produce, home gardening, and physical and mental health and healing.” Edgington, 300.
} 
Jim Minick offered a workshop on organic "weed control for vegetables and small fruits," while two other homesteaders led workshops on "labor efficient crops, permaculture and other strategies to provide a complete diet without the use of fossil fuel or synthetic inputs.” ${ }^{100}$ So even while the newer wave of homesteaders and "market gardeners" focused more on carving livelihoods out of agriculture than did their earlier self-sufficient counterparts, they still maintained that cooperative ethos that had defined the counterculture and the 1970s-era back-tothe-land movement. That spirit of cooperation and desire to foster the continual exchange of ideas, coupled with shared concerns about quality of life and environmental protection, helped to shape the alternative community's identity in Floyd.

“Making room here for each other's dreams": Economic Development in Floyd County

During the 1980s and 1990s, downtown Floyd slowly and steadily came back to life. A few years after the Harvest Moon's relocation to the county seat, the Friday Night Jamboree at the Floyd Country Store (or Cockram's Country Store, as it was called at the time) emerged as one of the New River Valley's prime tourist destinations. The Jamboree had its roots in informal weekly jam sessions that local musicians held there. As more people came to watch, it became a regular event. Visitors poured in from as far away as Europe to see the bluegrass, old-time, and gospel musicians pluck, strum, and croon high lonesome sounds and dancers gather to "flat-foot" in front of the stage. Then in 1991, seven years after the Harvest Moon's relocation, three alternative women (one of whom was a countercultural native of neighboring Franklin County) opened the New Mountain Mercantile, a store specializing in local crafts. Each blended together

100 “Farmer-to-Farmer Conference announced,” Floyd Press, December 31, 1992. 
existing small businesses to form the enterprise. Two of the women, Kalinda Wycoff and Theresa Cook, purchased the Epperly Mill after Harvest Moon and had been residing there as well as running their businesses out of the building. With these local developments in the downtown district, Floyd began to build a reputation as a thriving center for the arts. ${ }^{101}$

As often happens in "natural amenity" communities like Floyd that draw quality of life migrants, there was no shortage of debate in the 1980s and early 1990s over development. Generally, the alter-natives wanted to preserve the area's “uniqueness” and rural character, encourage cultivation of local businesses, and support small-scale farming, endeavors that they believed meshed well with locals' concerns for preserving the community's social fabric and agricultural heritage. Sometimes they were right. There were, at times, remarkable moments of cooperation between in-migrants and natives, particularly regarding issues related to the arts. Some natives had grown increasingly aware of environmental quality and the value of their local water. Both parties shared a love of the land. And both wanted to revitalize the downtown. The question, then, was how to go about doing that.

With downtown revitalization and ongoing migration into Floyd, county residents were at times thrust into uncomfortable dialogs that at their core were about what constituted “community.” Some people’s visions of community were either tinged with illusion or nostalgia, and so development debates, as Miles Orvell observes of the concept of "Main Street as utopia" in American memory, became "a story of the effort, and the failure, to define community.” In some ways the development debates made Floyd look less like the rural utopia that in-migrants imagined and more like a "borderland" in which different groups clashed over competing visions

\footnotetext{
${ }^{101}$ Melissa Pierson, “Flat-Footin' in Floyd, Va,” Washington Post, May 26, 1991; “Mountain Mercantile promotes local arts, crafts," Floyd Press, July 25, 1991. In spite of the Jamboree's success, the owner at the time, Freeman Cockram, struggled to keep it financially afloat. It faced bankruptcy in 1991 and 1992.
} 
of what the community should become and how it should function to meet the needs of an increasingly diverse population. ${ }^{102}$ The contests often reflected natives' desires to see jobs created in Floyd, which could help to stave off the outmigration of their young and thereby preserve familial and other social networks. They also reflected some residents' hopes to see Floyd move into the economic mainstream. People wanted amenities and believed that added businesses could improve community cohesion. The debates also exposed idealized notions of community, particularly visions of a co-dependent, self-sustaining, and decentralized society that could meet the needs of its own and protect the environment while reducing dependency on outside sources.

There were two extreme viewpoints that emerged in development debates. On one end of the spectrum were the "gangplank" in-migrants who moved to the county for its recreational opportunities, clean environment, cultural resources, and small-town feel, as well as nostalgic natives who feared the further deterioration of what they believed was once a relatively tight-knit and insular community. ${ }^{103}$ Those people vented against additional in-migration or community change. "It bothers me at times that there are so many people moving into Floyd," one person wrote. “I used to know the majority of people in the community, but I don’t know many of them

\footnotetext{
${ }^{102}$ Miles Orvell, The Death and Life of Main Street: Small Towns in American Memory, Space, and Community (Chapel Hill: University of North Carolina Press, 2012), 7. Citing Robert Bellah, Orvell contends that tension exists between the notions of "Main Street" and "Borderlands" in American memory. "Main Street exists as a place of relative homogeneity and security" and is typically "defined in opposition to the "world outside." But the notion is also infused with a "fear that sameness will create an inability" to navigate the realities of a more diverse population. People typically recognize, then, that Main Street can result in parochialism. Conversely, he suggests that the pervasive longing for a return to the mythical Main Street emanates from fears that groups too different from each other will never find common ground.

${ }^{103}$ D. J. Blahna, Turnaround Migration and Environmental Conflict in Northern Lower Michigan (PhD diss, University of Michigan, 1985); D.J. Blahna, “Social Bases for Conflict in Areas of Reverse Migration,” in Community and Forestry: Continuities and Sociology of Natural Resources, ed. R.G. Lee, D.R. Field, and W.R. Burch (Boulder, CO: Westview Press, 1990), 159-178. For the newer models, see Fortmann and Kusel, 214-232; M.D. Smith and R.S. Krannich, “Culture Clash Revisited: Newcomer and Longer-Term Residents' Attitudes Toward Land Use, Development, and Environmental Issues in Rural Communities in the Rocky Mountain West," Rural Sociology 65, no 3 (2000): 396-421. The gangplank theory is but one complication of an earlier understanding of native/newcomer relations called the "culture clash" theory, which attributed community conflict to value differences among different community groups.
} 
anymore.” That sentiment was echoed several times in the late 1980s and early 1990s, as was the general feeling that the rural character of the town and county were threatened. "Stop trying to change Floyd County into a bustling crime ridden area," said another. "This is one of the few rural areas left in the USA. Stop trying to hurry its changes.”104

On the other end of the spectrum were pro-development individuals, some native and some not, who sought to develop the county either for industry or tourism or both—anything that would bring jobs and badly needed tax revenue. Sam Brown and William D. Church, two entrepreneurial men not from the county but from nearby Pilot Mountain and Stuart, saw opportunities for profit in Floyd. Although they emphasized the importance of retaining the area’s aesthetic beauty, they recommended developing services and real estate to cater to tourists and vacation home owners. Their vision of development centered on the tastes and desires of wealthy tourists who they believed would consume elements of local culture like "handmade patchwork bedspreads" in hotel rooms and "homemade biscuits and country ham” that would “not be overcooked and greasy," suggesting that traditional Appalachian fare would not appeal to tourists' discriminating tastes. They planned, in essence, to try "to satisfy the needs of our new found friends,” the tourists. ${ }^{105}$ Developers like Brown and Church sought to market Appalachia’s environment and culture through “tangible symbols” largely divorced of their original purpose, creation, and meaning, and warned local residents, and especially “the local power structure,” that they "might have to relinquish" authority and "bite [their] upper lips a bit when some of the newcomers [tourists and second home owners] don’t agree with [them].”106

\footnotetext{
${ }^{104}$ Roger Lewis, “Change for Floyd stirs mixed emotions among surveyed,” Floyd Press, December 11, 1986.

${ }^{105}$ Roger Lewis, "Business developers urge county stress quality growth,” Floyd Press, September 18, 1986.

${ }^{106}$ Jobes, 209-210. In natural amenity communities like Floyd, the more development that occurs, the more likely it is that the community will attract entrepreneurial types like Brown and Church interested in capitalizing off of the development boom. "Since progressive and foresightful people are attracted to the promise of progress," asserts Jobes, "they head straight for such places, accelerating the process of development." Opposition to development and community debates over the issue do little to stem the tide of change. Jobes also explains that newcomers often
} 
Of course, most people fell somewhere in between the two extremes, with alter-natives generally advocating business development that could nurture the local economy and preserve the environment, and natives who desired added amenities but also hoped to preserve the community's rural heritage and social fabric. "Do we really want 'ANOTHER ANYTOWN USA?’” asked multigenerational resident Jeanie Harman O’Neill. O’Neill, who lived at the edge of downtown, supported development but in a manner that would preserve the downtown district's architecture and historical character. ${ }^{107}$ But the fact that the different groups shared respect for agricultural heritage and love of local cultural expressions did not necessarily lead to cooperation, especially regarding the types of development proposed in Floyd. Chain stores and restaurants were particularly divisive, for they went against many alter-natives’ preference for small-scale, decentralized enterprises that would leave a smaller carbon footprint, distribute wealth more evenly, and minimize inequitable labor arrangements. Well before there was ever a concrete proposal for fast food, county residents debated the benefits and drawbacks of chains. "I have heard rumors about the possibility of a shopping center and fast food restaurants” coming to Floyd, wrote Kamala Fenn [Bauer] in 1986. “As Floyd grows I realize this becomes more likely,” but "I'm concerned that the growth be attractive and beneficial to all residents.” She preferred local restaurants to chains and concluded, “Floyd is special. Let’s keep it that way.”108 Opposing opinions were expressed in a survey conducted in 1986. Many natives clearly desired the introduction of "a fast food restaurant or pizza place” into the community. And some even

engage in the construction of tangible symbols, "activities, conditions and objects that are established to protect or maintain valuable natural or social characteristics of the community." These symbols represent past linkages to the land in former agricultural communities but as presented to tourists and in-migrants are largely divorced of their original meaning and purpose.

${ }_{107}$ Jeanie Harman O’Neill, “Start Preserving,” Floyd Press, April 25, 1993.

${ }^{108}$ Kamala Fenn, “About Restaurants,” Floyd Press, April 10, 1986. 
voiced their frustration with individuals they believed were "afraid of growth" and who fought “every new thing mentioned." 109

Along with a host of other issues that emerged in relation to local economic development—zoning and waste ordinances, historic preservation, chain stores, a proposed interstate, and cultivating tourism—food in particular polarized portions of the county's population. As with other cultural expressions, foodways reflected the histories, values, and desires of the local and in-migrant populations. To this day, the collection of restaurants in downtown Floyd signals the presence of two distinct cultures that have left journalists, bloggers, and other visitors sometimes wondering if there is not an unbridgeable gap between the two subcommunities. One journalist, for example, described Floyd one as "a sometimes uneasy mix of Andy Griffith’s Mayberry and a Grateful Dead encampment." ${ }^{110}$ The Blue Ridge Restaurant, some said, which offered traditional local cuisine like pinto beans, cole slaw, and mixed greens, catered to the native population, while Oddfellas Cantina and Dogtown Pizza reflected the more eclectic, urban, and health-conscious palates of the alter-natives. Much of the discussion about food that came from alter-natives focused on local production, organic practices, and health, features that represented a broader set of "cosmopolitan" concerns. But many natives argued for their right to have access to modern conveniences like fast food that were, in the 1980s anyway, still a good forty-minute drive away.

Several years later, one of those "new things mentioned" was a proposed Hardees restaurant. In April of 1994 the Floyd Press reported official plans to bring Hardees to the community. Local business owner Larry Robbins sold a piece of property, once his father-in-

\footnotetext{
${ }^{109}$ Roger Lewis, “Change for Floyd stirs mixed emotions among surveyed,” Floyd Press, December 11, 1986; Roger Lewis, "Town meeting: Like as is, but growth worries citizens," Floyd Press, October 29, 1987.

${ }^{110}$ Rex Bowman, “Currency Plan Splits Floyd; Group: Local Money Will Boost Economy,” Richmond Times, July 26, 2000.
} 
law's car lot, to a Hardees franchisee based out of North Carolina. Rumors about the restaurant, which preceded the official announcement by almost a year, sparked an outpouring of sentiment both for and against chains. Those opposed to Hardees sometimes contrasted Floyd with other areas that had experienced urban development, particularly the kind that had sprung up along highways and interstates. "I can’t imagine a worse business to have in Floyd than a national fast food restaurant," wrote in-migrant craftsperson F. Michael Johnson. Floyd is a "unique small town that is not a carbon copy of all the concrete jungles that have grown up around interstate exits all over America.”111 “I couldn’t help but think about the so called progress that one sees between” Christiansburg and Blacksburg, reflected another person. "Five miles of mind numbing asphalt, malls, gas stations, burger joints and shopping centers with the same junk in perpetual sale mode." 112 Others went beyond mere aesthetics in their arguments against chains, offering sophisticated analyses of the global economy. Colleen Redman weighed the economic benefits of local versus global businesses, arguing in favor of the former on the grounds that Floyd could remain "more independent” and could "provide" its own "jobs, goods, and services." She cautioned that welcoming "big out of state businesses for the purchase of jobs" could subject local businesses to closure. ${ }^{113}$ Mark Schonbeck warned that "ill-considered pro-growth policies" actually exacerbated "poverty all over the world by concentrating ... power in the hands of giant corporations.” Instead of economic growth, "we need . . . economic justice, and sustainable

\footnotetext{
${ }^{111}$ F. Michael Johnson, “Fine in Concrete Jungles, But Not Here,” Floyd Press, April 25, 1993.

112 D.C. Lucera, “Artificially Bloated,” Floyd Press, October 8, 1992.

${ }^{113}$ Colleen Redman, "Out of Business?” Floyd Press, September 24, 1992; Michael Shuman, The Small-Mart Revolution: How Local Businesses are Beating the Global Competition (San Fransisco: Berrett-Koehler Publishers, Inc., 2006), 46-49. Redman and others were well aware of some of the risks associated with allowing corporate entities into small communities. Michael Shuman identifies several key advantages to encouraging local business development over allowing corporate entities to open in communities. He believes they are more financially sustainable and more likely to stay put in economic downturns than multinationals, offering much longer-term benefits for communities. Because they employ fewer people, when they do close, their "exits" are less destructive. Small businesses can also be held accountable more easily for any environmental or labor infringements, and they hold higher economic "multipliers," meaning that the money spent at a small business has a much higher percentage rate of community circulation than money spent in a chain store.
} 
development based on decentralized systems that are more socially equitable and environmentally efficient.” He charged that Hardees, with the few part-time positions it would offer, would do little to remedy the county's economic plight, for a majority of profits would go "to the parent corporation." 114

Although the controversy never became as heated as the Floyd Environmental Action Team's battle against the transformation of B-REAL or the anti-surface mining contests in Lincoln County, development debates like the one over fast food stoked outsider/insider resentments. It is difficult to pinpoint the exact moment that discussions devolved into newcomer versus native distinctions, but a week after F. Michael Johnson published his letter to the editor, he wrote again in response to an anonymous letter that he had received from a long-term resident who targeted Johnson as a "newcomer ... 'trying to run the county and not [letting] progress occur."” Johnson retorted that progress, in fact, was "brought by 'newcomers"” and the “’newcomers have rights just like you.” That same day, native Eric Huff distinguished between the desires of "true Floyd Countians" who wanted jobs and amenities, and those who opposed the restaurant, "most of whom did not originate in Floyd." ${ }^{\text {"15 }}$ Carlton Harmon warned that he would "see hell freeze over before" he would take any more resistance to development. "There are those of us in Floyd County who were born here and have had to spend most of our working lives traveling outside of the county to make a living," he charged, echoing sentiments of Lincoln County's miners during the surface mining debates. "The reason we didn’t move is because we kept hoping something would locate here to make our lives better.” Long-time residents liked the county, too, he asserted, “but that doesn’t mean we don't want it to change. It

\footnotetext{
${ }^{114}$ Mark Schonbeck, “Need Economic Justice,” Floyd Press, December 23, 1993.

${ }^{115}$ F. Michael Johnson, "Progress at Any Cost?” and Eric Huff, “Real World?” Floyd Press, December 2, 1993.
} 
can change for the better.”116 Ruby Vest shared similar feelings. She had traveled out of the county for most of her life to work, and wondered if "Floyd County is being divided by certain groups of people, not born and raised Floyd Countians.”"117

Of course, others were more nuanced in their approaches to the issue of corporate versus local development. Several natives and newcomers were more concerned about the appearance of the Hardees and how it would fit into the town's aesthetic and affect residents in the immediate downtown area than about the presence of the restaurant itself. Jeanie Harman O’Neill, who asserted that a Roanoke Times article misrepresented her sentiments regarding the chain, clarified in a letter to the Floyd Press that she was not opposed to the restaurant but was simply concerned about its proposed location, which bordered several residential properties, including hers, and how it might affect the downtown district's appeal to visitors. She called for an "Architectural Review Board, an Historic District” or zoning laws to mitigate growth and to retain the downtown's historic appeal, particularly if the county wanted to attract tourists. She recommended that people move beyond their "residents against business" or "hysteric historical purists against business growth" stances and "come together as a collective caring group of people.”118 Mike Johnson, whose residential property also bordered downtown, expressed frustration at the "them against us" attitude present at a recent town meeting. He claimed that he had seen the two petitions circulating in the community, neither of which was starkly for or against Hardees. Instead, "One says that the location is inappropriate, and the other asks that the building conform to community standards with a review by a local board.” To one person who allegedly expressed in disgust his or her desire to see the entire downtown bulldozed, he added,

\footnotetext{
${ }^{116}$ Carlton Harmon, “Change Can Be For the Better,” Floyd Press, December 30, 1993.

${ }^{117}$ Ruby Vest, “Here We Go Again,” Floyd Press, December 9, 1993.

118 O’Neill, "Start Preserving.”
} 
'I suggest that this person do what the 'newcomers' to Floyd have done. Leave their roots, relatives, friends, and places that they grew up with and go somewhere that suits them better.”119 Some of the alter-natives who had been in the county the longest likewise maintained more balanced perspectives on the issue of fast food. Will Bason, who admitted that fast food was not "everyone’s cardboard cup of tea," recognized how important it was to locals to have access to such modern conveniences. “To stand in their way just doesn’t seem right or smart,” he explained. Referring to both Jeanie’s and Mike’s letters, Bason noted that “neither . . . are the least bit who you'd think of as hippies.” He believed that they offered sound arguments against the proposed location of Hardees and suggested that in order to "make room here for each other's dreams,” community residents work together to identify a location suitable to all. ${ }^{120}$ Jayn Avery wrote a letter not in direct reference to Hardees but instead about the importance of the community coming together and finding agreeable solutions to the question of development. “The reality is we don't often agree and there is no place to run because the same issue faces everyone the world over. So we might as well stop positioning ourselves into 'for or against' or 'us and them'; or blaming others with whatever labels make us feel better about ourselves, and give our attention to solutions."121

Avery was against the Hardees, but she eventually understood locals’ viewpoints toward that type of development. She admitted that when she and others of her generation arrived, they had been a bit "self-righteous" about their worldviews and about their lifestyle preferences. "We didn’t understand, those of us that had grown up" in mainstream America, "who were trying to tell them, 'You know, you don't really want to go there—-the food's not even good for you.'” But she later acknowledged that "Most of the local people wanted the Hardees ... They wanted to be

\footnotetext{
${ }^{119}$ Mike Johnson, “Cooperation, Not Confrontation,” Floyd Press, December 9, 1993.

${ }^{120}$ Will Bason, "Weight to her Words," Floyd Press, December 9, 1993

${ }^{121}$ Jayn Avery-Grubel, "Same Issue,” Floyd Press, March 10, 1994.
} 
a part of the American culture, and it meant something ... to them to stop feeling so remote and removed and disregarded.” In light of the in-migrants’ activism over the environment and economic development, she realized that change "takes time. And so that has been tricky," she added, "how not to be proselytizers and arrogant in our own philosophy of organic and pure and clean and environmentally everything, when the people who grew up here just have to make ends meet, really just want a good job. They don't care if it’s a factory job, they just want to be able to get by. And you can’t blame them!”122

Avery's reflection on her own evolution regarding local versus alter-native preferences, and Bason's expression of tolerance toward fast food, signaled community cohesion that had slowly formed over the twenty year period since the first countercultural in-migrants arrived. In 2008, Colleen Redman admitted that she was far slower to write letters to the editor of The Floyd Press regarding certain issues than she had once been because she knew too many people in the community: “When I first moved here, I wasn't very sensitive to the local people, and I did things like wrote letters to the editor that I wouldn’t write today, because I know people’s faces now and they know mine!”

Integration was less advanced for newer alter-natives who had come in recent years. Redman and others suggested that more recent in-migrants had not connected to the community in the same way, so they were less inclined to hold back opinions and attitudes that might affront the local culture. As two sociologists who studied community dynamics between natives and newcomers in Western North Carolina suggest, "The longer these in-migrants spend in the region, the more they tie themselves to the community through their interactions and relationships.” Additionally, the longer the in-migrants remain, the more they come to see certain

\footnotetext{
${ }^{122}$ Jayn Avery, interview by author, Floyd, Virginia, July 23, 2008.
} 
forms of development as potentially damaging to the community's social fabric and to the area's cultural heritage. ${ }^{123}$ Fast food might have gone against the alter-natives' values of "organic and pure and clean," but it was a less important issue to some who had been in Floyd the longest than it was to newer alternative in-migrants who came with new illusions and expectations of what the now mythical Floyd—with its Appalachian and countercultural elements—could offer them in terms of "live and let live" attitudes, a pristine environment, and a high quality of life in the Appalachian mountains.

Floyd's multigenerational residents and oldest wave of alter-natives accepted certain forms of development for the amenities they provided, the jobs they created, and the new energy they could bring to the community, but their tolerance for change also had its limits.

Gentrification and changes in the community's social structure were particularly troubling. County planner Lydeana Martin asserted that people who came in the 1990s and 2000s hoping to farm were typically unable to do so because of the high cost of land. ${ }^{124}$ A person writing on an Internet forum asked to hear from other Floyd residents who struggled "just to pay their new property taxes and fuel costs.” In the same thread, which had occasionally devolved into hostile banter about the merits and drawbacks of a charismatic hippie "leader" nicknamed "Sparky" who had passed away in 1999, another man vented that the alternative culture had long since abandoned its "radical politics" and embraced instead a "selective nostalgia for the 60s" that resulted in "hippies who are basically capitalists, trying to market Floyd as the new Haight

\footnotetext{
${ }^{123}$ Brennan and Cooper, "Rural mountain natives," 292.

${ }^{124}$ Lydeana Martin, interview by author, Floyd, Virginia, July 25, 2012.
} 
Ashbury district.” Others, the person added, sought to keep themselves, and particularly their children, segregated from county "rednecks,” resulting in a local “apartheid system.”125

Will Bason, who was one of the first countercultural arrivals to the county, had similar concerns about downtown development and ongoing community divisions. “They’ve upscaled it beyond my liking, I tell ya. It's kind of gentrified in my opinion.” Behind the development were the newer "rich hippies” or "wealthy alternative minded people," who he believed had not been "reading the same kind of bioregional” literature that he read "in the '80s," which dismissed tourism as a drain on natural resources. A self-described "cornbread and pinto bean kind of old fashioned hippie," Bason confessed that he did not "really understand the appeal” of tourism “or why they think that it's sustainable to base” the economy on that industry. So while the downtown may seem “hipper,” he explained, the “people who have been here longer aren’t really the people who are” driving the downtown's development. ${ }^{126}$ In some ways, then, economic development exposed community divisions in Floyd, although not across the lines that one might have expected. Over time, many of the first generation of alter-natives blended—although certainly not enough to have earned the title "native” by locals-into the community’s social fabric, while they and many multigenerational residents wrestled with the question of what it meant to continue hosting new populations of in-migrants, including countercultural types, second home owners, and tourists, in Floyd County.

“Report gathering dust”: Economic (Under)Development in Lincoln County

\footnotetext{
${ }^{125}$ Freeman, “Living in Floyd,” Tribe.net, www.tribes.tribe.net/floydcounty/thread/1ae81d5b-694e-4b94-957586b9aa53698c (accessed May 23, 2012).

${ }^{126}$ Will Bason interview.
} 
Lincoln County alter-natives and native craftspeople sought to transform their community in a way similar to Floyd, although the interest in doing so appeared comparatively weak, particularly when looking at local politicians' responses. Alter-natives like Jim Probst and Paul and Freda Smith hoped to cultivate a home-grown crafts and small business market in Hamlin. Recall that they eagerly participated in the business meetings in 1987 that followed the release of the economic development report and explored the possibility of fostering local value-added manufacturing of timber. But locals accomplished little in the two years following the report's release to Lincoln County public officials. Using the headline, "Report gathering dust,” journalist Paul Carson questioned local officials who had agreed to pay $\$ 7,400$ to match a federal grant for the report about what actions had been taken to bolster the local economy. "How wise was the investment?” he asked. The men interviewed expressed their disappointment with the report but ultimately backed their decisions to commission it on the grounds that they now had "a plan on record ... of what” needed to be done. One expressed his rather feeble hope that the county might receive federal money in the future to follow through with some of the plans, while the other largely dismissed it as a "lesson in how the fat of government works." The study, he grumbled, "was part of a special program the government was offering rural undeveloped counties." "They had some money to spend and they wanted us to chip in a little bit to help them spend it."127

The failure to adopt any of the report's suggestions resulted from more than a lack of federal funding at the time to invest in infrastructure and economic development. The same day in March of 1989 that Carson published his update on the economic development report, the Lincoln Journal featured Jim Probst's woodshop, which enjoyed success in spite of the

$\overline{{ }^{127} \text { Carson, "Report gathering dust." }}$ 
challenges of running "a luxury-type business . . . in a depressed state . . . in one of the most depressed counties in the state” and several additional articles that, collectively, signaled systemic problems that contributed to the lack of development in West Virginia's most rural counties. One chronicled the town of Hamlin's decision to implement a tax on local citizens so that it could bolster lost revenue that had previously threatened the existence of "its two-member police force.” Another revealed that West Virginia’s Secretary of State Ken Hechler had attempted to pass a bill that would have prevented politicians' relatives from manning the polls. Together, the articles pointed to deeply ingrained problems within West Virginia's political economy that hinted at why Lincoln County failed to develop in the same way as Floyd. ${ }^{128}$

West Virginia had a long history of political corruption that stemmed from politicians’ cozy relationship with industry, typically coal, that prevented any other forms of development from occurring, particularly in the southern coalfields. ${ }^{129}$ Hechler’s proposal to eliminate politicians' family members at the polls was one of several measures that progressive state

\footnotetext{
${ }^{128}$ Lisa Graley, “Building on a dream”; James Heffern, “Town fee passed,” Lincoln Journal, March 15, 1989; Carson, "Report gathering dust”; Paul Carson, "Democracy as we know it," Lincoln Journal, March 15, 1989. There were some geographical differences between the two counties that might have accounted for the difference; Floyd is composed of more rolling hills and Lincoln, situated in the Allegheny Plateau, is much more rugged, although the peaks do not rise above 1,500 feet. Other areas of West Virginia, like Clarksburg, however, diversified their economies in spite of topography. Human capital was available in both communities as well, at least throughout the 1970s and early 1980s, for alter-natives and like-minded natives in both communities became actively engaged in reform measures and particularly environmental causes. The New River Valley had some existing cultural resources, such as the Blue Ridge Parkway, that led local leaders to embrace tourism as a supplement to manufacturing and farming. But in the mid-1990s, southern West Virginia sought to capitalize on heritage and recreational tourism by creating a network of trails called the Hatfield-McCoy trail system, named after the famous late- $19^{\text {th }}$ century feud. Lincoln County leaders at least nominally expressed interest in the proposed trail system in 1994, but the trail ended up skirting the county for reasons that are unknown. So although there were some differences, the cultural and geographical compositions of the counties still looked somewhat similar between the 1980s and early 1990s. See also, "Lincoln Supports New Trails," Charleston Gazette, March 9, 1994; Roger Mannon, "NRV HOSTS promote Floyd as tourist destination,” Floyd Press, January 21, 1993.

${ }^{129}$ Ben A. Franklin, “Appalachian regional study finds absentee ownership of $43 \%$ of land,” The New York Times, April 5, 1981. As the Hatfield-McCoy Trail example above suggests, another problem with economic diversification was, and still is, corporate landownership, particularly in the southern coalfields. The Appalachian Land Ownership Study discovered that $43 \%$ of land in the region was controlled by absentee owners. This, the study concluded, meant that people were systematically denied the most desirable plots of land for cultivation and/or development, the tax structures limited the available services to regional residents, and economic growth was largely dependent on outside forces.
} 
leaders had taken in the 1980s and 1990s to try to clean up the state's image. Paul Carson offered what was likely a tongue-in-cheek assessment of the proposal, stating that such a move would “end democracy as we know it" in Lincoln County by disqualifying a significant percentage of the poll workers who oversaw the county's "by-the-book elections.” To have elections at all, he added, the county would have to import poll workers from outside of the community, because nearly everybody was related. Although West Virginia at the time of Hechler's proposal was the only state that still allowed family members of politicians to work at polls, the proposed law failed to pass by one vote. ${ }^{130}$

The political misconduct continued. In 2000, Scott Finn of the Charleston Gazette ran a series of award-winning articles that exposed corrupt policies and practices in the state government and the measures to which state politicians went to cover up their relationships with industry. He noted the more famous cases of corruption, including Arch Moore in 1988, who was charged with extortion, mail fraud, and tax evasion. Following Moore’s administration, Governor Gaston Caperton passed “a new governmental ethics law” that nodded to cleaning up state politics but did not go nearly far enough in making government dealings with industry transparent. As one historian notes, a national study rated "West Virginia's public disclosure laws ... 4 $3^{\text {rd }}$ in the nation.” Finn compared West Virginia's and Maryland's disclosure laws, claiming, “In 1999, Maryland lobbyists spent more than \$23 million. If they reported only what the West Virginia law requires, they would have reported \$757,356 only in spending.”131

The statewide political culture of dependency on outside corporate wealth and the continued relationship between industry and politics at both the state and county level

\footnotetext{
${ }^{130}$ Carson, "Democracy as we know it."

${ }^{131}$ Scott Finn, "Cycle of influence: Ethics law falling short of promise to clean up government, critics say," Charleston Gazette, July 23, 2000; John Alexander Williams, West Virginia: A History (Morgantown: West Virginia University Press, 2001), 224-225.
} 
diminished the political will to explore economic alternatives to extractive industries. The "historical marriage" between politics and coal in particular led to the creation of "super tax breaks” during Governor Moore’s third term between 1985 and 1989. As historian Shirley Stewart Burns charges, the tax credits predominately benefited "the coal industry which enjoyed 90 percent of the total super tax breaks.” Part of the arrangement was to reduce by thirty percent the amount of money coal companies had to contribute to workers' compensation funds, and in some cases it helped coal operators to skirt the newly imposed severance tax. The result: the super tax breaks "cost the state millions of dollars in revenue.” In that same period, the amount of lost revenue went from $\$ 600,000$ to $\$ 48.2$ million. And because of the shift to surface mining in the southern coalfields, the number of coal jobs plummeted while production increased. This trend helps to explain why coal miners in Lincoln County, so many of whom had to commute out of the county to find work, were so quick to welcome Black Gold into the community. ${ }^{132}$

The alliance of business and politics at the state level had far-reaching effects on Lincoln County in the late $20^{\text {th }}$ century. Burns notes that the number of people receiving federal assistance increased in the coalfield counties, and the overall effect was a decline in services available to residents. Not only did the town of Hamlin face the prospect of losing its police force in 1988, but a year later the county lost its agricultural extension agent because of uncertainty about the position's financial security. This hurt farmers who relied on the agent's advice for maximizing annual crop yields. Lincoln County Commission President Vernon McCoy maintained that his administration was forced to choose between keeping employees in the courthouse and having an extension agent. The same month, the Board of Education made cutbacks by eliminating nine teachers, five bus drivers, and several additional positions, as

\footnotetext{
${ }^{132}$ Shirley Stewart Burns, Bringing Down the Mountains: The Impact of Mountaintop Removal on Southern West Virginia Communities (Morgantown: West Virginia University Press, 2007), 66.
} 
reported in March of 1989. ${ }^{133}$ And while the state Department of Employment Security estimated that the county had an unemployment rate of $8.7 \%$ in early 1989, federal figures showed that much higher, at 13\%. Even those estimates may have been low; County Clerk Larry Z. Adkins estimated rates at around 30\% because the other two departments had not counted people traveling out of the county to find work. ${ }^{134}$

Systemic political corruption left a strong impression on several alter-natives who recalled the ways in which politicians manipulated citizens or engaged in otherwise unethical behavior. Jan Salstrom asserted that political support was sometimes re-paid through the Department of Transportation. If rural residents wanted their roads improved, they would have to wait until after elections to have gravel distributed on unpaved roads. Those who did not vote for the proper candidates did not receive improvements. Jeremiah Greenberg, who occasionally worked on road crews in the county, recalled that the best jobs typically went to those people with political connections. Even the union, he asserted, was tied into politics. And as a marijuana lobbyist, he witnessed firsthand statehouse shenanigans; he supplied marijuana for politicians in Charleston who wanted to entertain their mistresses, and recalled that several of the politicians to whom he provided joints were eventually indicted on corruption charges. ${ }^{135}$

Native West Virginian Julian Martin, who moved to the county in the 1970s to teach and had relationships with both the alter-natives and natives in the county, had similar impressions of county-level politics that he much later relayed in a series of editorials in the Charleston-Gazette. Some of his stories of voter fraud and vote buying came from second-hand information, but he

\footnotetext{
${ }^{133}$ Burns 68-69; James Heffern, “Town fee passed”; James Heffern, "Farmers will miss agent,” Lincoln Journal, March 22, 1989; James Heffern, "Board cuts 9 teachers, 5 bus drivers, 5 others,” Lincoln Journal, March 29, 1989.

${ }^{134}$ James Heffern, “Adkins says local jobless rate may be 30\%," Lincoln Journal, January 11, 1989.

${ }^{135}$ Jan Salstrom, interview by author, Morgantown, WV, November 20, 2008; Greenberg interview.
} 
had valid reasons for believing they were reliable. As he understood it, a typical voting precinct operated with family connections, confirming Hechler's assertion about state politics. Lincoln County had two political factions that vied for control, and services to local residents depended on whether or not they had voted for the winning faction. One "faction of the Democrat Party controlled the Board of Education, the County Commission and the welfare department thus controlling almost all of the jobs in the county. A poor person or one of their relatives," he added, "could easily get hurt economically for not cooperating with that kind of power." Vote buying was common, as were political favors. As Martin asserted, the county's large number of poor residents were the most susceptible to the temptation of selling votes. The cure for such behavior was "full employment at decent wages," for "people with good jobs seldom sell their votes.” At one typical precinct, he learned that about 160 votes had been "for sale.” Confirming Jan Salstrom’s assertion, Martin claimed that his friend's “wife worked inside the polling place and gave signals to the paymaster outside when bought votes were cast as directed. A vote sold to the winning side might get some gravel in your driveway courtesy of the other taxpayers. On Election Day dirt roads all over Lincoln County were paved.” Vote the right way and a person could receive money or get out of traffic tickets. And "the older generation likes to sell their votes for some whiskey while the younger go for marijuana." Vote for the wrong faction and a person could be subject to harassment, as happened to a local bar owner who suddenly found the road outside of his establishment constantly patrolled by police seeking to pull patrons over as they left. ${ }^{136}$

Martin did more than just relay second-hand information about county politics to the state’s largest newspaper. He later told a story about a Board of Education meeting that he had

\footnotetext{
${ }^{136}$ Julian Martin, “Buying votes in Lincoln County,” Charleston Gazette, January 24, 2006.
} 
attended in the early 1980s that exposed the level of control that the ruling Democratic faction exacted over the local population. Martin was a teacher, so he became upset upon learning at the meeting that "the brother-in-law of the superintendent of Lincoln County schools" had received a $\$ 2,000$ pay raise, “while teachers got nothing.” Martin spoke out against the proposed raise, and after the meeting, the superintendent threatened to punch Martin. The superintendent's brotherin-law followed through with the threat, bloodying Martin’s face. The following day Martin visited the state police office to file a complaint but was threatened with physical violence upon attempting to do so. ${ }^{137}$

But even local news reporters, who likely had to be careful about what they reported, at times vented their frustration over the county’s political landscape. The Lincoln Journal covered local political scandals, but the indictments typically resulted in settlements, at best, and cases being thrown out on technicalities, at worst. It was evident that authorities made little concerted effort, especially locally, to correct the problem. Factional struggles drove one new journalist in the county, Joe Farruggla, to write a rather brash piece on West Virginia politics and the state of the county’s political economy. He began by informing readers of a travel agency in California that had marketed West Virginia as the "Third World" of America to pique the morbid interests of vacationers interested in poverty tours. While he was clearly annoyed with the exploitative approach to tourism, he admitted that the advertisement was “not without justification.” He blamed the state's cycle of poverty in part on its citizens who, he claimed, were fatalistic and apathetic about their futures, but he also pointed to local politics as a significant factor in southern West Virginia’s abysmal economy. The same population that did little to advance beyond their parents’ achievements in work or educational endeavors likewise never challenged

${ }^{137}$ Julian Martin, “A lesson on trusting the police,” Charleston Gazette, January 7, 2011. 
local elites. ${ }^{138}$ His understanding of the local attitude was, “'I always voted Democratic, just like my parents did. It doesn't matter who you vote for anyway, they're all a bunch of crooks; my kids will vote the same way, too.”,139

Farruggla believed that the politicians took advantage "at every turn . . . especially ... in the lower counties of the state." He listed some of the common "shenanigans" that local officeholders used to maintain power- - slatemaking, vote-buying, backroom 'deals' cut to determine who will hold office, and when”-and concluded that Lincoln County's factionalism was “strangling the county's lifeblood and keeping it from realizing any real potential it has for growth.” The main difference between the Third World countries he had visited (Mexico, Jamaica, and Brazil), and West Virginia was that residents in those countries tolerated corrupt politics only to a certain extent. Each had its own example of citizens eventually rising up to challenge political leaders. "They have learned what we have forgotten: that when things go too far, the ballot is the most powerful voice of change. And they cherish that voice, being willing to stand bravely in line despite the possibility of assassination or serious injury for daring to vote their conscience and their conviction. What will it take," he concluded, “for Lincoln Countians to wake up and realize that their vote can really count and that it is the most important tool they have to bring about real change?”140

The alter-natives who arrived in the 1970s and remained in the county in spite of political corruption, an abysmal economic outlook, and the prospect of commuting to other communities to find gainful employment, helped to politicize the local population when it came to issues of

\footnotetext{
138 Joe Farruggla, "State of the Third World," Lincoln Journal, January 9, 1991. Farruggla, expressing a "culture of poverty" viewpoint that cast blame for residents' impoverished conditions on their culture, and particularly fatalism, made no mention of surface mine debates or other issues in which local residents had been involved during the 1980s.

${ }^{139}$ Farruggla, "State of the Third World."

${ }^{140}$ Farruggla, "State of the Third World."
} 
education, tax reform, the environment, and even, in spite of the odds, economic development. Their grassroots organizations challenged local elites but not to the point of completely altering the county's political landscape. The odds were too highly stacked against them. As John Alexander Williams discovered in a study that he cited in his conclusion to West Virginia: A History, "West Virginia is one of nine states where the growth of citizens' groups, single-issue lobbies, and other manifestations of expanded participation in policy determination at the state level has had the least impact." ${ }^{141}$ The political machine that existed in Lincoln County, which was just one facet of a culture of corruption in the state that had a long history extending back to the industrial era, had little tolerance for challenges to its power. In some ways the efforts that entrepreneurial alter-natives and natives put forth to change the economic landscape were as good as that economic development report that was left "gathering dust" two years after it was delivered to county officials.

Had the county had some infrastructure in place, such as decent roads, a good educational system, telecommunications, or the political will to seek those amenities, then quality of life migrants, countercultural or otherwise, might have continued to migrate there. Or, perhaps more importantly, energetic and motivated young people from the county might have sought to remain rather than leave to find opportunities elsewhere. Instead, even through the 2000s, county leaders continued their factional debates, continued to ignore economic diversification, continued to manipulate the political system by buying votes and inflating absentee ballot counts, continued to cater to the industrial status quo, and actively blocked efforts by at least one "cosmopolitan" native visionary who sought to transform the county into an arts and music destination that could

\footnotetext{
${ }^{141}$ Williams, 224.
} 
have rivaled Floyd. ${ }^{142}$ Little wonder then that the Rondys, the Shews, and hundreds of other alter-natives migrated out to greener pastures to raise their children, to cultivate farms and nurture forests and become part of the social landscape.

Conclusion:

By 2002, the economic structures of Floyd and Lincoln Counties looked remarkably different. The Appalachian Regional Commission classified Floyd as a "transitional” county, presumably for its low unemployment rate over a three-year period (3.8\%). The county's poverty rate in 1990 had been $14 \%$, and its per capita market income in 1998 was $\$ 13,424$. The county was by no means wealthy, but it fared much better than Lincoln, still categorized as “distressed." The reasons: Lincoln still had a poverty rate of $33.8 \%$, a per capita income of $\$ 9,609$, and an unemployment rate of 11.5\% between 1990 and 1997. Lincoln County’s average unemployment rate was a shocking $252.5 \%$ higher than the U.S. average. ${ }^{143}$

In the language of sociologists who study "green" or "quality of life" migrations, the difference between communities like Floyd and Lincoln are their economic trajectories as “natural resource” or "natural amenity” communities. Floyd was a natural amenity community with leaders who, as agriculture declined, slowly turned toward tourism as a viable economic complement to manufacturing and other industries that could offer higher paying jobs. ${ }^{144}$

\footnotetext{
${ }^{142}$ For some recent examples of political corruption, see Toby Coleman, "Lincoln circuit clerk arrested, Stowers accused of buying votes for politicians with cash, liquor," Charleston Gazette, May 6, 2005. For information on Dan Butcher, a Lincoln County millionaire who sought to transform the county into a major arts community, see Joe Morris, "Making news in Lincoln; Native-son millionaire shaking up county,” Charleston Gazette, March 4, 2007; Probst interview.

${ }^{143}$ Appalachian Regional Commission, “County Economic Status in Appalachia,” Appalachian Regional Commission, http://www.arc.gov/research/MapsofAppalachia.asp?MAP_ID=64 (accessed February 6, 2013 ).

${ }^{144}$ Avery interview. Jayn Avery noted that one source of tension between activist newcomers and the local County Board of Supervisors was just the slow pace of change in the county. She described them as generally very
} 
Community leaders eventually sought to capitalize on the local culture and scenery, but this was partly because they already had key resources in place like the Blue Ridge Parkway and, eventually, the New River Valley HOSTS, an organization dedicated to bolstering the area's tourist industry. In the mid-1990s, southern West Virginia created a network of trails called the Hatfield-McCoy trail system, named after the famous late- $19^{\text {th }}$ century feud. Lincoln County leaders expressed interest in the proposed network in 1994, but it ended up skirting the county for reasons that are not completely known, although county leaders indicated that they would have to obtain the permission of corporate landowners in order to approve the system. ${ }^{145}$ So the county's proximity to the coalfields, and its own coal, oil, and natural gas reserves, once again prevented economic diversification. It also perpetuated a corrupt political culture that remained dedicated to extractive forms of economic development. Pro-commodity community leaders demonstrated little interest in transitioning the county away from its focus on natural resource extraction, and Lincoln County continued to host corrupt political machines that were exclusionary toward anyone who challenged their power.

Each community's respective position as a resource and amenity community shaped the ways in which alter-natives in each location integrated into social networks and participated in discussions about development. Both communities saw a fair amount of cooperation when interests overlapped — with barter, with illicit production of moonshine and/or marijuana, with timber and the protection of land—and both similarly had periods of conflict when their different visions of community clashed. Most often the conflict could, at its core, be attributed to locals' preferences for integrating into the mainstream and preserving the integrity of their communities

\footnotetext{
“conservative," but over time she and others came to accept that they represented "a voice that is very important” to the community.

${ }^{145}$ Ken Sullivan, The West Virginia Encyclopedia (Charleston: The West Virginia Humanities Council, 2006), 121; "Lincoln Supports New Trails," Charleston Gazette, March 9, 1994. Absentee owners control over fifty percent of Lincoln County's land.
} 
by encouraging local job creation no matter the source. The more cosmopolitan alter-natives and natives envisioned communities that would be healthy, vibrant, and self-sustaining for generations to come. That meant promoting long-range planning and sacrificing certain shortterm gains.

Floyd may have a more difficult time in the future than Lincoln navigating differing values and preferences as it continues to attract quality of life migrants. It is clear from alternatives' recollections that newer arrivals come with their own unique set of expectations that sometimes coincide with earlier migrants' interests in protecting the environment, promoting healthy lifestyles, and preserving Floyd's small town “feel," but sometimes do not. In some ways, alter-natives’ integration after Lincoln County’s strip mine battles may have become smoother because fewer remained to pose challenges to local elites. Craftspeople like Probst pressed on and involved themselves with other initiatives, but the success that they realized came more from their own initiative than from any political support they received from local or state leadership. 


\section{Chapter Seven}

\section{Becoming “Citizens” of Appalachia:}

\section{Alter-natives' Integration into Floyd and Lincoln Counties}

Citizen Action and Community Dynamics in Floyd and Lincoln Counties:

Dan Butcher organized Lincoln County Friends of the Arts in the spring of 2006. Butcher was a Lincoln County native who, like so many others of his generation, had left as a young adult to find work elsewhere. But after making millions in the landscaping business, he decided to return to Lincoln to "turn the county around.” Beginning in late 2005, Butcher funded all sorts of community projects. He donated $\$ 300,000$ to the new Lincoln County High School to purchase computer software and equipment for its auditorium, plotted to build a craft school that would hire local artisans like Jim Probst to teach Lincoln County residents new skills, sponsored performances by musical legends Dr. Ralph Stanley and Loretta Lynn, purchased storefronts in downtown Hamlin for revitalization, and funded festivals and community arts programs. Butcher created the Friends of the Arts with the hope of transforming the community into a new cultural destination in West Virginia that could rival western North Carolina in terms of its appeal to heritage tourists, artists, musicians, and other culture seekers. ${ }^{1}$

Probst was astonished at Butcher’s ability to motivate people. The woodworker had previously been involved with a local youth camp but recalled having had difficulty finding people to volunteer. Butcher, on the other hand, had a gift for motivating people and quickly garnered not only their support, but also their time and energy. He "had fifty people coming” to Friends of the Arts meetings “on a monthly basis” in a very short period of time. Probst admitted

\footnotetext{
${ }^{1}$ Jim Probst, interview by author, Hamlin, WV, March 23, 2011; Olena Goryelova, "Lincoln festival features Mattea, Stanley,” Charleston Gazette, November 9, 2006.
} 
that he had "never seen anything like it.” For two years Butcher acted as a human dynamo, planning, collaborating, and networking with people to implement his ideas. He studied other communities like Asheville, North Carolina—and perhaps even Floyd—that had revitalized their downtowns and had evolved into heritage tourist destinations. He hoped to emulate those transformations. $^{2}$

Not surprisingly, as Butcher began to wield significant influence in the community, local politicians began "throwing obstacles" in his way. Although the details of conflicts are unclear, Butcher began speaking out to the Charleston Gazette about corrupt county politics. He informed the paper that the "county had been dominated by a political party with one head," and those powerful families had "infiltrated the school board and county government.” In response to opposition, Butcher started his own newspaper, the Lincoln Standard, to compensate for what he viewed as a "lack of open dialogue" in the county. ${ }^{3}$ He described the Standard as a political "lightening rod" that was meant to "give the voice back to the community." It succeeded in its objective for the short period of time it was in operation. The online paper garnered a lot of attention, particularly because of its attacks on county politics. One "column on political corruption ... got 3,300 unique visits.” Standard contributors accused the supposedly Republican-leaning Lincoln Journal of "plagiarism and charging illegally high rates for its political advertisements.” Butcher filed a federal lawsuit on that latter point, forcing the Journal and its counterpart, the Democratic Weekly News Sentinel, to become more distinct from each other. His action resulted in the sale of the papers to politician Lyle Stowers of Cabell County. The Standard also discovered that the county's food pantries only served five to seven percent of the county’s poor. Butcher understood that the newspapers in southern West Virginia coal

\footnotetext{
${ }^{2}$ Probst interview.

${ }^{3}$ Probst interview; The Associated Press, "Lincoln gets new online newspaper," Charleston Gazette, December 25, 2006.
} 
counties were “dominated by absentee owners who squeeze every cent they can,” so he even expanded his online enterprises into neighboring Boone, Logan, and Putnam counties. ${ }^{4}$

But as sometimes happens with charismatic leaders, Butcher burned himself out; his vision and energy were short-lived. The details of his decision to abandon Lincoln County are not entirely clear, but Jim Probst recalled that he had grown paranoid about the nature of the political backlash that he received as a result of his involvement in the county: "He started telling me his life was being threatened and people were trying to run him off the road and entering him into lawsuits.” Butcher reportedly had a belligerent personality, and that may have exacerbated his problems. His newspapers ceased operations in 2008. But Probst, who has had some difficulties of his own navigating the local power structure (the "muckety-mucks,” as Michael Tierney called them), assigned equal blame to county elites who felt threatened by Butcher’s money and elevated influence. ${ }^{5}$ The wave of political scandals that plagued the county in the 1990s had not abated; in 2005 the county’s circuit clerk Greg Stowers was arrested “on charges that he bought votes for politicians with cash and liquor for more than a decade.” Shortly following that scandal, a former tax assessor, Jerry Weaver, "pleaded guilty to conspiracy to buy votes." 6 Probst explained that Butcher troubled the "powers that be” because he "was throwing money around.” The politicians in turn "started throwing obstacles in his path. And they started getting offended by him."7 So while it may be impossible to determine whether or not local elites actually harassed or threatened Butcher, for he died in 2011, it is clear that his activities,

\footnotetext{
${ }^{4}$ The Associated Press, "Lincoln gets new online newspaper”; Joe Morris, "Making news in Lincoln, Native-son millionaire shaking up county,” Charleston Gazette, March 4, 2007; "Lincoln philanthropist, publisher dies," Charleston Gazette, August 26, 2011.

${ }^{5}$ Michael Tierney, interview by author, March 23, 2011. Michael Tierney believes that Probst has had more conflict with the local power structure because of his economic success, whereas he, who predominately works with children and the elderly in his programs, has remained non-threatening.

${ }^{6}$ Toby Coleman, "Lincoln circuit clerk arrested Stowers accused of buying votes for politicians with cash, liquor," Charleston Gazette, May 6, 2005; Tom Searls, "Two sentenced in Lincoln vote fraud; Weaver gets one year, Stowers six months in prison,” Charleston Gazette, May 10, 2006.

${ }^{7}$ Probst interview.
} 
particularly his creation of local newspapers that exposed corruption and encouraged citizen participation, unleashed a political hornet's nest in the county.

In a sense, what Butcher envisioned for Lincoln County was what Floyd seemed to have become, at least according to the bevy of national news articles covering the community in the mid-to-late 2000s. The articles celebrated Floyd as an "idyllic" location known for its "homegrown food, art, and music.” In 2001, alter-natives Kris Hodges and Erika Johnson, the original owners of Oddfellas Cantina, launched Floydfest, an annual world music festival that through the years has drawn national recording artists and showcased up-and-coming regional musicians. ${ }^{9}$ Virginia's Crooked Road Heritage Trail opened in 2004, introducing even more tourists and folk music enthusiasts to the county. The 250-mile trail down the spine of Virginia's Blue Ridge was founded to "support tourism and economic development in one of Appalachia's distressed areas," reported the Washington Post. ${ }^{10}$ Then in 2005, newcomer Woody Crenshaw purchased the financially strained Floyd Country Store and its Friday Night Jamboree. Crenshaw had originally homesteaded in Giles County before moving back to Raleigh, North Carolina, to take over his father's lighting business. But he and his wife wanted to return to the mountains, so they moved the business and themselves to Floyd, believing that it was "the place where the quality of life by [their] standards is the highest." Crenshaw poured money into the venue, transforming it into a major tourist destination with additional space for dancing and souvenirs. ${ }^{11}$ So over the last forty years, Floyd transformed from a simple one-stoplight agricultural county

\footnotetext{
${ }^{8}$ Haya El Nasser, "Va. Town on Slow City pace before movement began: Ideology nurtured in Europe urges communities left behind by globalization to keep themselves small and use their strengths to sustain their economies," USA Today, November 22, 2006.

${ }^{9}$ Ralph Berrier, Jr., "Floyd to host world music; Floydfest, which begins Friday, can accommodate up to 14,000 fans,” The Roanoke Times, September 23, 2002.

${ }^{10}$ Melanie D.G. Kaplan, "Play me that mountain music,” Washington Post, October 4, 2009.

${ }^{11}$ Kevin Kittredge, "Floyd company makes lighting fixtures with style, caring craftsmanship," The Roanoke Times, August 16, 1998; Whitney Mitchell, “Floyd Country Store: Alive \& Kickin',” The Roanoke Times, June 22, 2007.
} 
into a virtual household name for musical aficionados, heritage tourists enthusiasts, counterculturalists, small farmers, and artists.

Both counties face their own set of problems as a result of their respective trajectories. Residents in Floyd worry about preserving the rural character of the community while also continuing to search for agreeable ways to create jobs for its residents. The highly celebrated town may be headed down the path of some western resort towns like Bozeman, Montana, where, in spite of community efforts to curb development, it continued through the second half of the twentieth century. It increasingly catered to the tastes and preferences of wealthier exurbanites who moved there in search of a higher quality of life. In a description that is eerily similar to Floyd’s experience, Patrick C. Jobes observes, “By 1980, downtown was rapidly becoming gentrified, retaining much of the façade of a diverse shopping and service center while losing much of the core retail trade establishments. By 1990, gentrification was nearly complete. Only one hardware store and one hometown café were left.”12 In Floyd, the local hardware store and the Blue Ridge Café are the two businesses left that nod to the town's agricultural roots. Gentrification troubles both Floyd’s leaders and residents. County planner Lydeana Martin asserted that it is nearly impossible for the average resident to own farmland, and landowners continue to sell to developers. “Jobs versus environment” debates still plague Floyd, just as they do coalfield communities like Lincoln County. And, as Jobes also notes, a high rate of citizen involvement does not always translate to peaceful community relations or feelings of satisfaction: “A high rate of participation may be related to strong negative feelings,” in fact, "as persons struggle to gain control for its own sake.” If the stakes are high enough, he continues, the community "can disintegrate," sometimes to the point of completely breaking down the networks

\footnotetext{
${ }^{12}$ Patrick C. Jobes, Moving Nearer to Heaven: The Illusions and Disillusions of Migrants to Scenic Rural Places (Westport, Connecticut: Praeger, 2000), 46.
} 
of "sharing among neighbors and friends that had existed for decades prior to ... development." To prove his point he cited a community that polarized over the issue of coal mining. ${ }^{13}$

In spite of the difficulties, Floyd was able to emerge out of its economic distress, although residents are by no means wealthy. Lincoln has not been so fortunate. The efforts of cosmopolitan-minded natives like Butcher and alter-natives like Probst in Lincoln County aside, the community will not move toward a more sustainable and balanced future until the county rids itself of political corruption and diversifies its economy. Probst and other in-migrants, with the support of like-minded natives, repeatedly drew upon their human capital to offer alternative visions of economic development, environmental sustainability, tax reform, and education (the latter two issues will be explored further upon publication) often to little avail, although they did enjoy some remarkable successes. The problem persists, as Richard Couto explains, because the amount of social capital that a community is able to create is often directly proportional to the economic prosperity of its citizens. "When groups of people have subordinate roles in the economy, the social capital goods and resources invested in them are modest. When people have no role in the economy, even less social capital goods and resources are invested in them.” But "when a community's economic condition improves, so will the social capital invested in it." By examining the two counties, it is easy to see how this process unfolds. In Floyd, the alter-natives carved livelihoods out of farming, the arts, or business ownership, or they, like many natives, commuted outside of the county to find work. According to Lydeana Martin, approximately 1,200 people are self-employed in Floyd County, nearly double the state average. ${ }^{15}$ Their economic independence afforded them a greater freedom to foster social capital

\footnotetext{
13 Jobes, 57-58.

${ }^{14}$ Richard Couto, Making Democracy Work Better: Mediating Social Structures, Social Capital, and the Democratic Prospect (Chapel Hill: University of North Carolina Press, 1999), 36.

${ }^{15}$ Lydeana Martin, interview by author, Floyd, Virginia, July 25, 2012.
} 
through organizations like the Educational Resource Cooperative. Some of the in-migrants were independently wealthy, and they contributed material capital to various initiatives, like the Blue Mountain School and the local scrip system. The majority of Floyd alter-natives were not necessarily wealthy, but they had sub-communal support that endured. They also operated within a tolerant political culture that, in spite of "localized" outlooks and occasional resistance to some of the alter-natives' wishes, nonetheless had long demonstrated a commitment to reviving the local economy. Alter-natives in Lincoln found financial support through similar means—-through the arts, self-employment, or by commuting out of the county—but their ability to contribute to the county's economic base was hindered by an obstinate political culture that showed little interest in economic diversification, revitalization, or infrastructure. Jim Probst, John Salstrom, and a few others in Lincoln County were able to participate in or head voluntary organizations in part because they were economically independent of the power structure; Probst was a woodworker and Salstrom a carpenter (until the latter took a job with the county government in June 2009). But Lincoln's alter-native sub-community atrophied as many people decided to leave rather than struggle to address the county's lack of resources and infrastructure.

Excepting perhaps its political culture, Lincoln County’s story in many ways resembles that of another community, Ivanhoe, Virginia, which is located just fifty miles to the west of Floyd. In the 1960s Ivanhoe began a long descent into economic depression when Union Carbide, the county's main employer, closed its plant. As a result, "the town diminished and people were scattered.” The business leaders who had once been affiliated with manufacturing and mining in the county likewise moved on, leaving a "leadership vacuum" in the community. Shifting economic patterns as a result of development along I-81 drew additional people away. Schools and businesses closed, and church membership declined. These processes resulted in 
"self-blame” among local residents, "self-perceptions of failure," the "belief that 'there is nothing'” the local population could do to remedy the situation, and a pervasive "distrust of outsiders." ${ }^{16}$ That self-consciousness about the plight of the community resulted in a passive population that for years did little to organize on its own behalf. Communities like Ivanhoe that exist on the economic margins also sometimes develop reputations for fighting. This "anger turned inward" translated to the community's inability to "negotiate, compromise, or trust outside helpers.” But as a result of several intense years of collaborative, participatory research, residents were able to regain their collective sense of self and began moving toward solutions that could provide "livelihood rather than profit," as sociologist and community organizer Helen Lewis reflected, and an "economic system that is more just and equitable." ${ }^{17}$

Lincoln County residents seem to have fallen into a similar state of powerlessness. The community developed the same bad reputation for violence as Ivanhoe ${ }^{18}$ and some of its residents at times exhibited both distrust of outsiders and self-consciousness about their impoverished state. But Lincoln Countians have, in other instances, demonstrated deep commitment to change in spite of the obstacles. Michael and Marcel Tierney, who moved to the Big Ugly section of the county, recalled having been unsure that they would receive any support for their efforts to introduce a Head Start program in that portion of the county. After a long struggle with administrators they finally received permission to use an old, boarded up community center for the program. Michael "wondered" if there would be "any community support because people [had] been so discouraged by the school system not letting [them] use it,”

\footnotetext{
${ }^{16}$ Mary Ann Hinsdale, Helen M. Lewis, and S. Maxine Waller, It Comes from the People: Community Development and Local Theology (Philadelphia: Temple University Press, 1995), 20-31, 332.

${ }^{17}$ Hinsdale, Lewis, and Waller, 31-34.

${ }^{18}$ Upon discussing her research in Lincoln County with various people in more urbanized areas of West Virginia like Morgantown and Huntington, the author was repeatedly warned to "be careful" when visiting the impoverished county.
} 
but when he "called a meeting ... twenty-two people showed up ... And people showed up the next day and started scrubbing the mold off the walls." ${ }^{19}$ Native West Virginians who had moved into Lincoln County from other locations, like Julian and Linda Martin, took on the county's Board of Education over issues related to educational quality, consolidation and the preservation of local schools, and political patronage. Others, like Thursy Baker, another West Virginian who had relocated to the county, and a number of landowners whose property would have been adversely affected by Black Gold, participated in grassroots organizations like Home Place. Hence, the community has shown potential for grassroots activism that could draw upon the human and social capital that both alter-natives and natives provide.

Of course, many alter-natives in both communities served as leaders for grassroots action or supported those initiatives, and so at times they helped to inject a new civic ethic into their communities. Those who established roots forged alliances with natives and sometimes won support because of their demonstrated work ethic, shared concern for preservation of the counties' cultural and agricultural heritage, and desire to nurture the local economy. Natives in both counties even sometimes expressed gratitude for the alter-natives' involvement. But, as outsiders, they also had to overcome suspicion from other locals and outright hostility from some local elites. They received slanderous remarks, sometimes had to assert their right to participate in the public dialog, and occasionally received threats to life and property.

Both natives and alter-natives sought to protect or restore community; many natives hoped to preserve their local support networks by staving off outmigration through any form of economic development. Their desperation to do so was occasionally reflected in the native/newcomer distinctions that emerged during developmental debates. The alter-natives

\footnotetext{
${ }^{19}$ Tierney interview.
} 
sought to build communities around networks of sharing as well but with a greater eye toward the environment's role in nurturing and protecting small communities for multiple generations.

Finding Common Ground and Becoming Native

What united alter-natives and natives from the start was, on some level, a shared sense of place and a shared interest, particularly among the newcomers and their immediate agrarian neighbors, in cultivating the land. Both parties exhibited reverence for independence and community, although the ways in which they demonstrated those ideals might have been different. Many on both sides abided by the "live and let live" mantra, albeit with important qualifications, even as they connected with each other to lend support and assistance in their depressed economies. But how the dual concepts of community and independence translated to action on a larger scale differed according to the circumstance. Competing visions of independence-_economic independence, property rights, personal liberties, and individual expression—sometimes prompted conflict, as did misunderstandings about the needs of each particular sub-community and their relationships to and reliance upon the natural world.

Alter-natives were overwhelmingly protective of nature. Even those who eventually chose to work off their farms or communes maintained a strong sense of stewardship toward the land. They continued to place nature at the center of their worldviews, so family and community interactions emanated from their commitment to place. They cultivated their sense of place in Appalachia through their perception of nature as the ultimate redemptive force. Their view of nature was a social construct born of their privileged positions as part of the white middle class - for they could afford to remodel their lives to reflect their disassociation with mainstream, consumerist America and migrate to areas far removed from urban crime and pollution—as well 
as various religious traditions and antimodernist sentiments that had pervaded American culture since the colonial era. ${ }^{20}$ But that reality should not diminish the powerful effects that feelings of kinship with nature had on the in-migrants. For many, nature was “church,” and they viewed threats to nature with as much apprehension as some natives felt in the 1970s toward the “hippies” who they believed were threatening their communities’ moral fiber. Alter-natives’ desire to protect the landscape was genuine and real, and their love for the land no less than those who had been born and raised in Appalachia. Nature offered the opportunity for self-reflection and growth, and land, whether communally or individually owned or held in trust, meant independence, which, in the Jeffersonian agrarian tradition, was supposed to be the foundation of a democratic society. ${ }^{21}$

Natives’ sense of place was somewhat different. As David Glassberg explains, growing up in a location cultivates powerful memories that can connect and bond a person to a specific location. “The memory of a place becomes a language through which we recall our past social networks and emotions.” The memories themselves can be more powerful than the events as they took place at the time. The implication of this, he argues, is that "our sense of place . . does not necessarily diminish” as a result of physical changes to the landscape. This suggests, then, that some natives might have been more tolerant of at least mild changes to the landscape because it did not affect their emotional connections to the place as much as it would have to people who saw nature as something to be preserved and protected in a pristine or semi-pristine state. Locals were more likely to resist changes that would have altered the social function of a specific place

\footnotetext{
${ }^{20}$ David Glassberg, Sense of History: The Place of the Past in American Life (Amherst: University of Massachusetts Press, 2001), 122. As Glassberg contends, "a sense of place does not spring naturally from the environment.” People view place according to worldviews shaped by "social characteristics such as age, gender, race, class, and physical condition.”

${ }^{21}$ Rebecca Kneale Gould, At Home in Nature: Modern Homesteading and Spiritual Practice in America (Berkeley: University of California Press, 2005), 232-233.
} 
rather than its aesthetic. Many locals in Floyd embraced Hardees because it would have provided a new space for social interactions that were under threat elsewhere in the community because of the county’s rapid demographic changes. “Even the most ordinary of landscapes can become a special place,” observes Glassberg, because "we remake those places by attaching our memories and meanings to them.” Thus, preserving the community’s social fabric could, depending on the situation, take precedence over preserving the local environment. ${ }^{22}$

Land meant independence to many natives as well, although there were different opinions about the ways in which people should be at liberty to use their land for personal gain. Many were not extreme in their resistance to government regulation, and some shared alter-natives’ concerns about the deleterious effects of certain practices on the environment and community as a whole, so they favored protective regulation. But others actively resisted local ordinances, zoning, and regulations that infringed property owners’ prerogatives, even if they acknowledged the communal benefits of having stronger government control. This "political libertarianism" that emerged very obviously during Floyd and Lincoln counties’ developmental debates could sometimes provoke tension between property rights advocates and cosmopolitans. ${ }^{23}$

One of the key questions underlying this study concerns the integration of alter-natives into regional communities and the questions that the process raises about how small communities navigate different values, ideals, and worldviews in the wake of migrations. Alter-natives came with their own illusions about what rural, small-town life could offer in terms of independence, personal liberation, and self-actualization. Some, particularly the earliest arrivals, believed that

\footnotetext{
${ }^{22}$ Glassberg, 115, 123. Still, this should not undermine some natives' reactions to the development of more extreme forms of surface mining, which have so dramatically altered the physical and social landscape that places once familiar are no longer recognizable. And surface mining has systematically dismantled communities, prompting mass relocation or outmigration, which can further incite remaining residents' resistance.

${ }^{23}$ Lydeana Martin interview. Lydeana Martin used this phrase to describe the general political outlook in Floyd County.
} 
they could achieve self-sufficiency on their own, but they quickly realized that the vision was fraught with difficulty. To survive, they accepted help from their native neighbors and became engrained in community support networks. As other simple-life seekers followed, alternative sub-communities formed in Appalachia, providing the new arrivals with support and free spaces through which they strategized to confront some of the complex issues facing the region. Many of those who stayed became committed to fighting for environmental, social, and economic justice even as they projected their own values into local developmental debates. Their participation led to conflict when the value systems of alter-natives and natives clashed, but there were also moments of cooperation between the two parties. The longer they remained, the more they began to value and desire to protect their communities' cultural heritage. So their involvement regarding the arts and culture was more openly received.

Ongoing debates that reflect the persistence of the independence versus community dichotomy in American society may also influence how alter-natives are, in the long term, accepted as part of Appalachia's social landscape. In 2001, writer Jim Minick pondered how long it would be before locals ever recognized him as a native. He lamented the locals' belief that it generally took about three generations before a family was accepted as "native." "I want to become native to this place," he said, "but by most folks’ standards, including our neighbors ... I'll never be able to claim this word.” Nor would his children. Only his grandchildren would. He pointed to both his sense of place and his sense of responsibility toward that place as reasons enough for him to be afforded that status. "I want to change the word native," he continued, "to mean: one who lives in a particular place," one who will defend the place "and its many communities, human and non-human," one who will improve "the health of all communities, learning the many histories, one who listens closely, learns the language of the place; and ... 
seeks divinity in all."24 Others similarly questioned when they would "graduate from an ‘outsider’ to an ‘insider’?’25

If Glassberg's observation is true about sense of place and the persistence of memory even in the face of change, alter-natives may indeed have to wait multiple generations before locals accept them as natives. The different concepts of community, or different approaches to preserving the community, and the delicate balancing acts that Floyd and Lincoln had to navigate between individual and community concerns, occasionally fomented resentment toward the inmigrants. But “native,” like “independence” and “community,” also meant different things to different people in different contexts. To some multigenerational Appalachians, the "native” status not only comes with sense of place but with the collective memories that go along with being in a particular location for a person’s entire life. "Native” can also mean name recognition. Children whose parents migrated out of Appalachia to find work are still often afforded legitimacy in their parents’ home communities because of their familial connections. The individual's character is often assessed based on familial connections. "The past is never your past in the South,” remarked Ivanhoe community activist Maxine Waller. Her statement acknowledged the reality that in many small communities, there is no anonymity with surnames; a last name speaks to the quality and character of the person, whether that individual deserves the family’s reputation or not. ${ }^{26}$ Yet to others, “native” might simply mean being born in a place. There are likely those natives, particularly members of families into which alter-natives or their children have married, who embrace the alter-natives as their own. And in multi-layered communities like Floyd that experience continual in-migration, newer arrivals likely already

\footnotetext{
${ }^{24}$ Jim Minick and Wendell Berry, “A Citizen and a Native: An Interview with Wendell Berry,” Appalachian Journal 31, no. 3-4 (Spring / Summer 2004): 8-9.

${ }^{25}$ Maggie Hennessey, “Don’t Sell Out,” Weekly News Sentinel, February 3, 1988.

${ }^{26}$ Hinsdale, Lewis, and Waller, 330.
} 
acknowledge the elder generation of alter-natives as natives or, at the very least, as long-term residents.

But "native” can mean something else entirely. Minick, who three years later still clearly wrestled with the designation, asked Wendell Berry in an interview to explain a passage from his early essay “A Native Hill”: "Here, now that I'm both native and citizen, there’s no immunity to what is wrong." Minick asked Berry to elaborate on the connection between "native” and "citizen.” Berry responded that he had written it upon the realization that he was going to remain on his land for life, and with that came the burden of responsibility for past "blunders." "So the word "citizen," he explained, "occurs in that sentence because of its implication of responsibility. You can be a native without consciously assuming responsibility. A citizen consciously assumes responsibilities that belong to the place, responding to the problems of the place." ${ }^{27}$ Citizens, whether native in the traditional sense or not, accept the responsibilities of placing community and environment—for environmental quality translates to quality of life—above the individual, and that, perhaps, is a more significant designation to achieve. So even while it remains to be seen at what point the people who migrated to Lincoln County, West Virginia, and Floyd County, Virginia, or their progeny, will be granted the right to shed the "alter" and become truly native, it is clear from their activism and involvement in community issues and debates that they have, over the last forty years, at the very least become "citizens” of Appalachia.

\footnotetext{
${ }^{27}$ Minick and Berry, 8-9.
} 


\section{Bibliography}

\section{Manuscript collections:}

- $\quad$ Archie Green. The Archie Green Papers 1944-2009. The University of North Carolina Libraries Southern Folklife Collection.

- John Salstrom personal papers.

- $\quad$ Local Scrip Study Group. Local Scrip Study Group Papers. Copies in the author's possession, originally found in Jesse Peterman Memorial Library, Floyd, Virginia.

\section{Newspapers and news journals:}

- Charleston Gazette. 1968-2011.

- $\quad$ The Floyd Press. 196

- $\quad$ The Glenville Democrat. 1975

- $\quad$ Huntington Herald-Dispatch. 1964-1988

- Lincoln Journal / Weekly News Sentinel. 1969-

- $\quad$ New York Times. 1969, 1987

- $\quad$ Richmond Times. 2000

- $\quad$ Roanoke Times. 1995-2010

- $\quad$ USA Today. 2003-2006

- $\quad$ Wall Street Journal. 1971.

- Washington Post. 1981-1992

\section{Miscellaneous publications (hearings, magazines, web resources):}

- Appalachian Regional Commission. “County Economic Status in Appalachia.” Appalachian Regional Commission. http://www.arc.gov/research/MapsofAppalachia.asp?MAP_ID=64 (accessed February 6, 2013 ). 
- Awad, Amer. "Please, Don’t Tread on Me: A Case Study of a Dairy Farm in the Appalachian South.” http://anthro.appstate.edu/field-schools/papers/2007/awad (accessed February 6, 2013).

- “Chapter 42: Solid Waste.” Floyd County, Virginia, November 2, 1992. http://library.municode.com/index.aspx?clientId=13477 (accessed April 26, 2013).

- Communities (also Communitas).

- Educational Resource Cooperative Newsletter (Museletter).

- Freeman. "Living in Floyd.” Tribe.net. http://www.tribes.tribe.net/floydcounty/thread/1ae81d5b-694e-4b94-9575-86b9aa53698c (accessed May 23, 2012).

- Gatta, John. “Rediscovering the Earth.” The Sewanee Review 112, no. 4 (Fall 2004): 622.

- Glover, Paul. “Creating Community Economics with Local Currency.” Ithaca HOURS. http://www.paulglover.org/hourintro.html (accessed January 7, 2013).

- Green Revolution.

- Houriet, Robert. “Communing in Meadville.” Ramparts Magazine, November 30, 1968.

- Howdon, James and John Ryan. “The Floyd County Community Survey Full Report.” Blue Ridge Institute for Community, August 2005.

- Last Whole Earth Catalog.

- Mike McGee. “Fiddlin \& feudin.” Village Voice, April 9, 1970. http://www.lib.unc.edu/mss/sfc1/fiddlers/HTML_Final/Articles/1970/1970_032570_Protean Radish.htm (accessed June 25, 2012).

- Morganthau, Tom and Frank Maier. “America’s Small Town Boom.” Newsweek, July 6, 1981.

- Mother Earth News.

- Mountain Worker.

- Nair, Lindsay. "Community Supported Agriculture Programs in Southwest Virginia.” Roanoke.com. http://www.roanoke.com/columnists/nair/wb/232740 (accessed January 21, 2013).

- NORML. "NORML report on U.S. Domestic Marijuana Production: 1998 Marijuana Crop Report,” NORML marijuana production statistics. 
http://norml.org/pdf_files/NORML_US_Domestic_Marijuana_Production.pdf (accessed February 24, 2012).

- New River Community Action. “New River Community Action Home Page.” New River Community Action. http://www.swva.net/nrca/ (accessed August 29, 2012).

- Peyton, David. “Appalachian Culture Boom.” The Nation, November 8, 1975.

- “Poverty Rates, 1980: Appalachian West Virginia.” Appalachian Regional Commission. http://www.arc.gov/reports/region_report.asp?FIPS=54999\&REPORT_ID=13 (accessed July 15, 2012).

- Rodale, Robert. "Rural Renaissance on the Way.” Organic Gardening and Farming, September 1975.

- " “Seven Springs Farm: Meet the Farmers.” Seven Springs Farm. http://csa.7springsfarm.com/meet-the-farmers/ (accessed January 24, 2013).

- Thompson, Rob. “The Lion and the Lamb: The Way It Was at Union Grove.” Source Unknown, April 5, 1970. http://www.lib.unc.edu/mss/sfc1/fiddlers/HTML_Final/Articles/1970/1970_040570_US_01. htm (accessed June 25, 2012).

- “Union Grove Fiddling Festivals: Will the Real Fiddler’s Convention Stand Up?” Protean Radish, March 25, 1970.

http://www.lib.unc.edu/mss/sfc1/fiddlers/HTML_Final/Articles/1970/1970_032570_Protean Radish.htm (accessed June 25, 2012).

- United States Department of Agriculture. “Quick Stats.” Floyd County, Virginia. http://quickstats.nass.usda.gov/results/86CBBCEC-A29C-3A51-8173-B0370DC5C457 (accessed January 21, 2013).

- West Virginia Coal Regulatory Program, Oversight Hearing before the Subcommittee on Mining and Natural Resources of the Committee on Interior and Insular Affairs, House of Representatives, $100^{\text {th }}$ Cong., $2^{\text {nd }}$ Session, Serial No. 100-39, 1988.

- West Virginia Strip Mining. Public Hearing held by the West Virginia Department of Energy, June 28, 1988. Special Collections Department, Marshall University.

- Whaley, Abe. "Soon a Place Like Any Other: It's Heartbreaking to Watch the Appalachia I Love Disappear Under Endless Condos and Cabins.” Newsweek, November 14, 2005.

- Whole Earth Catalog.

- Williamson, Seth. “The New Pilgrims of Floyd County.” The Roanoker April, 1981. 
- Wise, Steve. “Old Time Fiddlers’ Convention.” Great Speckled Bird. April 10, 1972.

\section{Oral Interviews:}

- Connie Abraham, Flatwoods, WV, March 18, 2011.

- Bill Ambrose, Wood County, WV, January 27, 2011.

- Jayn Avery, Floyd, VA, July 23, 2008.

- A’Court Bason, Floyd, VA, August 1, 2011.

- Will Bason, Floyd, VA, September 25, 2011.

- $\quad$ Kamala Bauer, Floyd, VA, August 1, 2011.

- Garry Biggers, Black Mountain, NC, June 12, 2008.

- $\quad$ Katherine Chantal, Floyd, VA, August 3, 2011.

- Jim Chojnacki, Lincoln County, WV, July 2, 2011.

- Melody Cochran, Floyd, VA, August 3, 2011.

- $\quad$ Fred First, Floyd, VA, July 23, 2008.

- $\quad$ Paul Gallimore, Leicester, NC, June 12, 2008.

- Joanie Goldsmith, Morgantown, WV, June 24, 2011.

- Ed Gralla, Floyd, VA, August 4, 2011.

- Jeremiah Greenberg, Morgantown, WV, May 26, 2011.

- $\quad$ Jane Hearne, Wood County, WV, January 27, 2011.

- $\quad$ Ron Juftes, Floyd, VA, July 16, 2011.

- Ric MacDowell, Hamlin, WV, June 30, 2008.

- “Karen Martin,” Floyd, VA, September 26, 2011.

- Julian Martin, Morgantown, WV, June 10, 2010. 
- $\quad$ Lydeana Martin, Floyd, VA, July 25, 2012.

- Susan Meade, Floyd, VA, July 20, 2011.

- $\quad$ Tony Norris, Morgantown, WV, May 19, 2011.

- Jim Probst, Hamlin, WV, March 23, 2011.

- Cindy Rank, Morgantown, WV, July 31, 2008.

- Colleen Redman, Floyd, VA, July 23, 2008.

- Kip Rondy, Athens, OH, March 24, 2011.

- Jason Rutledge, Floyd, VA, July 21, 2011.

- Jan Salstrom, Morgantown, WV, November 20, 2008.

- Jan Salstrom, Greenville, NC, May 13, 2012.

- John Salstrom, Hamlin, WV, December 18, 2008.

- Paul Salstrom, Morgantown, WV, March 6, 2008.

- $\quad$ Mack Samples, Duck, WV, July 8, 2008.

- Greg and Verena Sava, Nicholas County, WV, May 20, 2011.

- Jack Spadaro, Richmond, KY, March 12, 2011.

- $\quad$ Luke Staengl, Morgantown, WV, November 27, 2011.

- $\quad$ Lynn Stasick, Morgantown, WV, March 2, 2008.

- Jennifer Taylor-Ide, Morgantown, WV, February 28, 2011.

- Michael Tierney, Charleston, WV, March 23, 2011.

- Wanda Vest, Check, VA, August 5, 2011.

- Barbara Weaner, Randolph County, WV, January 22, 2011.

- Judy Williams, Morgantown, WV, January 14, 2011. 


\section{Books and articles:}

- Agnew, Eleanor. Back from the Land: How Young Americans Went to Nature in the 1970s, and Why They Came Back. Chicago: Ivan R. Dee, 2004.

- Allen, Bill. "Save Our Cumberland Mountains: Growth and Change Within a Grassroots Organization." In Fighting Back in Appalachia: Traditions of Resistance and Change, edited by Stephen L. Fisher, 85-100. Philadelphia: Temple University Press, 1993.

- Beaver, Patricia D. Rural Community in the Appalachian South. 1986. Reprint, Prospect Heights, Illinois: Waveland Press, 1992.

- Becker, Jane S. Selling Tradition: Appalachia and the Construction of an American Folk. Chapel Hill: University of North Carolina Press, 1998.

- Berkowitz, Edward D. Something Happened: A Political and Cultural Overview of the Seventies. New York: Columbia University Press, 2006.

- Blahna, D.J. "Social Bases for Conflict in Areas of Reverse Migration.” In Community and Forestry: Continuities and Sociology of Natural Resources, edited by R.G. Lee, D.R. Field, and W.R. Burch. Boulder, CO: Westview Press, 1990.

- _ _ _Turnaround Migration and Environmental Conflict in Northern Lower Michigan." PhD diss., University of Michigan, 1985.

- Borsodi, Ralph. Flight from the City: An Experiment in Creative Living on the Land. 1933. Reprint, New York: Harper Colophon Books, 1972.

- Brauer, Carl M. "Kennedy, Johnson, and the War on Poverty.” Journal of American History 69, no. 1 (June 1982): 98-119.

- Brennan, Kathleen M. and Christopher A. Cooper. "Rural mountain natives, in-migrants, and the cultural divide.” The Social Science Journal 45 (2008): 279-295.

- Brinkerhoff, Merlin B. and Jeffrey C. Jacob. “Quasi-Religious Meaning Systems, Official Religion, and Quality of Life in an Alternative Lifestyle.” Journal for the Scientific Study of Religion 26, no. 1 (March 1987): 63-80.

- Brinkley, Alan. The End of Reform: New Deal Liberalism in Recession and Reform. New York: Vintage Books, 1995.

- Brown, Dona. Back to the Land: The Enduring Dream of Self-Sufficiency in Modern America. Madison: The University of Wisconsin Press, 2011. 
- Burns, Shirley Stewart. Bringing Down the Mountains: The Impact of Mountaintop Removal on Southern West Virginia Communities. Morgantown, WV: West Virginia University Press, 2007.

- Center for Economic Research. County Data Profile: Lewis - Marion. Morgantown: West Virginia University Press, 1993.

- Coberly, Lenore McComas. The Handywoman Stories. Athens, OH: Swallow Press, Ohio University Press, 2002.

- Cohen, Lizabeth. A Consumer's Republic: The Politics of Mass Consumption in Postwar America. New York: Vintage Books, 2003.

- Couto, Richard A. "The Memory of Miners and The Conscience of Capital: Coal Miners' Strikes as Free Spaces.” In Fighting Back in Appalachia: Traditions of Resistance and Change, edited by Stephen L. Fisher, 165-194. Philadelphia: Temple University Press, 1993.

- Couto, Richard A. and Catherine S. Guthrie. Making Democracy Work Better: Mediating Structures, Social Capital, and the Democratic Prospect. Chapel Hill: University of North Carolina Press, 1999.

- Cox, Craig. Storefront Revolution: Food Co-ops and the Counterculture. New Brunswick, NJ: Rutgers University Press, 1994.

- Craven, Christa. Pushing For Midwives: Homebirth Mothers and the Reproductive Rights Movement. Philadelphia: Temple University Press, 2010.

- Cronon, William. "The Trouble with Wilderness; or, Getting Back to the Wrong Nature.” In Uncommon Ground: Rethinking the Human Place in Nature, edited by William Cronon, 7077. New York: W.W. Norton, 1996.

- Doherty, Brian. Radicals for Capitalism: A Freewheeling History of the Modern American Libertarian Movement. New York: Public Affairs, 2007.

- Dudziak, Mary L. Cold War, Civil Rights: Race and the Image of American Democracy. Princeton: Princeton University Press, 2000.

- Edgington, Ryan H. “'Be Receptive to the Good Earth': Health, Nature, and Labor in Countercultural Back-to-the-Land Settlements.” Agricultural History 82, no. 3 (Summer 2008): 279-308.

- Eller, Ronald D. Uneven Ground: Appalachia Since 1945. Lexington: University Press of Kentucky, 2008.

- Engelhardt, Elizabeth S.D. “Creating Appalachian Women’s Studies: Dancing Away from Granny and Ellie May.” In Beyond Hill and Hollow: Original Readings in Appalachian 
Women's Studies, edited by Elizabeth S. D. Engelhardt, 1-24. Athens: Ohio University Press, 2005.

- Evans, Sara M. and Harry C. Boyte. Free Spaces: The Sources of Democratic Change in America. New York: Harper and Row, 1986.

- Fallam, Robert. “The Expedition of Batts and Fallam.” In West Virginia: Documents in the History of a Rural-Industrial State, edited by Ronald L. Lewis and John C. Hennen. Dubuque, IA: Kendall / Hunt Publishing Company, 1991.

- Fisher, Stephen L., ed. Fighting Back in Appalachia: Traditions of Resistance and Change. Philadelphia: Temple University Press, 1993.

- First, Fred. Slow Road Home: A Blue Ridge Book of Days. Floyd, VA: Goose Creek Press, 2007.

- Fortmann, L. and J. Kusel. "New Voices, Old Beliefs: Forest Environmentalism Among New and Long-Standing Rural Residents.” Rural Sociology 55, no. 2 (1990): 214-232.

- Gitlin, Todd. The Sixties: Years of Hope, Days of Rage. New York: Bantam Books, 1987.

- Glassberg, David. Sense of History: The Place of the Past in American Life. Amherst: University of Massachusetts Press, 2001.

- Gould, Rebecca Kneale. At Home in Nature: Modern Homesteading and Spiritual Practice in America. Berkeley: University of California Press, 2005.

- Griffin, Larry J. and Ashley B. Thompson. “Appalachia and the South: Collective Memory, Identity, and Representation.” Appalachian Journal 29 (Spring 2002): 296-327.

- Guthman, Julie. Agrarian Dreams: The Paradox of Organic Farming in California. Berkeley: University of California Press, 2004.

- Hale, Grace Elizabeth. A Nation of Outsiders: How the White Middle Class Fell in Love with Rebellion in Postwar America. New York: Oxford University Press, 2011.

- Hall, Jacquelyn Dowd. "Disorderly Women: Gender and Labor Militancy in the Appalachian South.” Journal of American History 73 (September 1986): 354-382

- Hamby, Alonzo. "The Vital Center, the Fair Deal, and the Quest for a Liberal Political Economy.” The American Historical Review 77, no. 3 (June 1972): 653-678.

- Harman, Patricia. Arms Wide Open: A Midwife’s Journey. Boston: Beacon Press, 2011.

- Hinsdale, Mary Ann, Helen M. Lewis, and S. Maxine Waller. It Comes from the People: Community Development and Local Theology. Philadelphia: Temple University Press, 1995. 
- Hodgson, Godfrey. America in Our Time. Garden City, NY: Doubleday and Company, Inc., 1976.

- Howe, Daniel Walker. What Hath God Wrought: The Transformation of America, 18151848. New York: Oxford University Press, 2007.

- Inscoe, John C. ed., Appalachians and Race: The Mountain South from Slavery to Segregation. Lexington: University Press of Kentucky, 2001.

- Isserman, Maurice and Michael Kazin. America Divided: The Civil War of the 1960s, $2^{\text {nd }}$ ed. New York: Oxford University Press, 2004.

- Jacob, Jeffrey. New Pioneers: The Back-to-the-Land Movement and the Search for a Sustainable Future. University Park: The Pennsylvania State University Press, 1997.

- Jobes, Patrick C. Moving Nearer to Heaven: The Illusions and Disillusions of Migrants to Scenic Rural Places. Westport, Connecticut: Praeger, 2000.

- Johnson, Kenneth M. and Calvin L. Beale. "The Recent Revival of Widespread Population Growth in Nonmetropolitan Areas of the United States.” Rural Sociology 59, no. 4 (1994): 655-667.

- Jones, Robert Emmet, et. al. "Green Migration into Rural America: The New Frontier of Environmentalism?” Society and Natural Resources 16 (2003): 221-239.

- Jones, Robert Emmet, et. al. "How Green is My Valley? Tracking Rural and Urban Environmentalism in the Southern Appalachian Ecoregion.” Rural Sociology 64, no. 3 (1999): 482-499.

- Kahn, Kathy. Hillbilly Women. Garden City, NY: Doubleday and Company, 1973.

- Katznelson, Ira. "Was the Great Society a Lost Opportunity?” In The Rise and Fall of the New Deal Order, edited by Steve Fraser and Gary Gerstle, 185-205. Princeton: Princeton University Press, 1989.

- Kiffmeyer, Thomas. Reformers to Radicals: The Appalachian Volunteers and the War on Poverty. Lexington: The University Press of Kentucky, 2008.

- Kirk, Andrew G. Counterculture Green: The Whole Earth Catalog and American Environmentalism. Lawrence: University Press of Kansas, 2007.

- "Labor Force Statistics from the Current Population Survey." Bureau of Labor Statistics. June 20, 2008. http://www.bls.gov/cps/prev_yrs.htm (accessed April 30, 2009). 
- Lauterer, Jock. Hogwild: A Back-to-the-Land Saga. Boone, North Carolina: Appalachian Consortium Press, 1993.

- Lears, T.J. Jackson. No Place of Grace: Antimodernism and the Transformation of American Culture: 1880-1920. Chicago: University of Chicago Press, 1981.

- Lewis, Helen and Monica Appleby. Mountain Sisters: From Convent to Community in Appalachia. Lexington: University Press of Kentucky, 2003.

- Loeb, Penny. Moving Mountains: How One Woman and Her Community Won Justice from Big Coal. Lexington: University Press of Kentucky, 2007.

- Lorence, James J. A Hard Journey: The Life of Don West. Urbana: University of Illinois Press, 2007.

- Martinez-Brawley, Emilia E. Perspectives on the Small Community: Humanistic Views for Practitioners. Silver Spring, MD: National Association of Social Workers Press, 1990.

- Martinez, Steve et. al., Local Food Systems: Concepts, Impacts, and Issues (Washington, D.C.: United States Department of Agriculture, Economic Research Service, Economic Research Report Number 97, May 2010),

- Mason, Carol. "From Textbooks to Tea Parties: An Appalachian Antecedent of Anti-Obama Rebellion.” West Virginia History: A Journal of Regional Studies Vol. 5, no. 2 (Fall 2011): $1-27$.

- _ Reading Appalachia From Left to Right: Conservatives and the 1974 Kanawha County Textbook Controversy. Ithaca, NY: Cornell University Press, 2009.

- McCauley, Deborah Vansau. Appalachian Mountain Religion: A History. Urbana: University of Illinois Press, 1995.

- McCoy, Alfred W. "The Stimulus of Prohibition: A Critical History of the Global Narcotics Trade.” In Dangerous Harvest: Drug Plants and the Transformation of Indigenous Landscapes, edited by Michael K. Steinberg, Joseph J. Hobbs, and Kent Mathewson, 24111. New York: Oxford University Press, 2004.

- Miller, Timothy. The 60s Communes: Hippies and Beyond. Syracuse, NY: Syracuse University Press, 1999.

- _ _ . The Hippies and American Values. Knoxville: University of Tennessee Press, 1991.

- Minick, Jim. The Blueberry Years: A Memoir of Farm and Family. New York: Thomas Dunne Books, 2010. 
- Minick, Jim and Wendell Berry. "A Citizen and a Native: An Interview with Wendell Berry.” Appalachian Journal 31, no. 3-4 (Spring / Summer 2004): 300-313.

- Montrie, Chad. To Save the Land and People: A History of Opposition to Surface Coal Mining in Appalachia. Chapel Hill: The University of North Carolina Press, 2003.

- Moran, Lisa. "Negotiating Boundaries or Drawing the Line? Transcending 'Insider/Outsider’ Distinctions in Connemara.” Irish Journal of Sociology 16.2, (2007): 136159.

- Morgan, Edward P. The 60s Experience: Hard Lessons about Modern America. Philadelphia: Temple University Press, 1991.

- Morrell, Ricki. “Trade You My Alienation for Some of Your Herb.” Appalachian Journal 24, no.3 (Spring 1997): 250-251.

- Nearing, Scott. The Making of a Radical: A Political Autobiography. New York: Harper Colophon Books, 1972.

- Newfont, Kathryn. Blue Ridge Commons: Environmental Activism and Forest History in Western North Carolina. Athens: University of Georgia Press, 2012.

- Nisbett, Robert A. The Quest for Community: A Study in the Ethics of Order and Freedom. New York: Oxford University Press, 1953.

- Norman, Gurney. Divine Right’s Trip. 1971. Reprint, Frankfort, KY: Gnomon Press, 1990.

- O’Brien, John. At Home in the Heart of Appalachia. New York: Alfred A. Knopf, 2001.

- Orvell, Miles. The Death and Life of Main Street: Small Towns in American Memory, Space, and Community. Chapel Hill: University of North Carolina Press, 2012.

- Patterson, James T. Grand Expectations: The United States, 1945-1974. New York: Oxford University Press, 1996.

- Perry, Huey. They'll Cut Off Your Project: A Mingo County Chronicle. 1972. Reprint, Morgantown: West Virginia University Press, 2011.

- Phillips, Scott K. "Natives and Incomers: the symbolism of belonging in Muker parish, North Yorkshire.” In Symbolising Boundaries: Identity and diversity in British cultures, edited by Anthony P. Cohen. Manchester, UK: Manchester University Press, 1986.

- Reichard, Gary W. Politics as Usual: The Age of Truman and Eisenhower. Wheeling, IL: Harlan Davidson, Inc., 1988. 
- Rose, Vivian Ellen. "Homesteading as Social Protest: Gender and Continuity in the Back-tothe-Land Movement in the United States, 1890-1980.” PhD diss., State University of New York: Binghamton, 1997.

- Roszak, Theodore. Person/Planet: The Creative Disintegration of Industrial Society. Garden City, NY: Anchor Press / Doubleday, 1978.

- Sale, Kirkpatrick. Green Revolution: The American Environmental Movement, 1962-1992. New York: Hill and Wang, 1993.

- Salstrom, Paul. Appalachia's Path to Dependency: Rethinking a Region's Economic History, 1730-1940. Lexington: University Press of Kentucky, 1994.

- _ _ _ _Cash is a Four-Letter Word.” Appalachian Journal (Spring 1989): 242-255.

- _ _ “The Neonatives: Back-to-the-Land in Appalachia’s 1970’s.” Appalachian Journal 30, no. 4 (Summer 2003): 308-323.

- Samples, Mack. Hippies and Holiness. Marceline, Missouri: Walsworth Publishing Company, 1999.

- Schlosser, Eric. Reefer Madness: Sex, Drugs, and Cheap Labor in the American Black Market. Boston: Houghton Mifflin Company, 2003.

- Schmitt, Peter J. Back to Nature: The Arcadian Myth in Urban America. 1969. Reprint, Baltimore: Johns Hopkins University Press, 1990.

- Schulman, Bruce. The Seventies: The Great Shift in American Culture, Society, and Politics. Cambridge, MA: DaCapo Press, 2001.

- Schumacher, E.F. Small is Beautiful: Economics as if People Mattered. New York, NY: Harper \& Row, 1973.

- Shapiro, Henry. Appalachia On Our Mind: The Southern Mountains and Mountaineers in the American Consciousness, 1870-1920. Chapel Hill: University of North Carolina Press, 1986.

- Shi, David. The Simple Life: Plain Living and High Thinking in American Culture. Athens: University of Georgia Press, 1985.

- Shuman, Michael. The Small-Mart Revolution: How Local Businesses are Beating the Global Competition. San Fransisco: Berrett-Koehler Publishers, Inc., 2006.

- Skolnick, Jerome H. "A Critical Look at the National Drug Control Policy.” Yale Law and Policy Review 8, no. 1 (1990): 75-116. 
- Smith, Barbara Ellen. “Appalachian Identity: A Roundtable Discussion,” Appalachian Journal (Fall 2010): 56-77.

- Smith, M.D. and R.S. Krannich. "Culture Clash Revisited: Newcomer and Longer-Term Residents' Attitudes Toward Land Use, Development, and Environmental Issues in Rural Communities in the Rocky Mountain West.” Rural Sociology 65, no. 3 (2000): 396-421.

- Starnes, Richard D. Creating the Land of the Sky: Tourism and Society in Western North Carolina. Tuscaloosa: University of Alabama Press, 2005.

- Stephenson, John B. "Escape to the Periphery: Commodifying Place in Rural Appalachia," Appalachian Journal 11, no. 3 (Spring 1984): 187-200.

- Swann, Robert and Susan Witt. "Local Currencies: Catalysts for Sustainable Regional Economies.” New Economics Institute. http://neweconomicsinstitute.org/publications/authors/Swann/Robert/local-currenciescatalysts-sustainable-regional-economies (accessed December 20, 2012).

- Thompson, Charles D. Jr. Spirits of Just Men: Mountaineers, Liquor Bosses, and Lawmen in the Moonshine Capital of the World. Urbana: University of Illinois Press, 2011.

- Trauger, Amy. "Un/Re-Constructing the Agrarian Dream: Going Back-to-the-Land with an Organic Marketing Co-Operative in South-Central Pennsylvania, USA.” Tijdschrift voor Economische en Sociale Geografie 98, no. 1 (2007): 9-20.

- Walker, Melissa, et al. Southern Women at the Millennium: A Historical Perspective. Columbia: University of Missouri Press, 2003.

- Weaver, Sharon. "First Encounters: 1970 Back-to-the-Land, Cape Breton, NS, and Denman, Hornby and Lasqueti Islands, BC.” Oral History Forum d'histoire orale 30 (2010): 1-30.

- West Virginia Department of Mines. Annual Report of the Department of Mines for the Fiscal Year Ending June 30, 1920. Charleston: Tribune Print Co., 1920.

- Annual Report of the Department of Mines for the Fiscal Year Ending June 30, 1930. Charleston: Tribune Print Co., 1930.

- _ _ Annual Report of the Department of Mines, 1970. Charleston: Tribune Print Co., 1970.

- Whisnant, David. All That is Native and Fine: The Politics of Culture in an American Region. Chapel Hill: University of North Carolina Press, 1983.

- Williams, John Alexander. Appalachia: A History. Chapel Hill: The University of North Carolina Press, 2001. 
- _ _ West Virginia: A History. Morgantown: West Virginia University Press, 2001.

- Williamson, Jerry. Hillbillyland: What the Movies Did to the Mountains and What the Mountains Did to the Movies. Chapel Hill: University of North Carolina Press, 1995. 